\title{
GENÉTICA DA REAÇÃO DA SOJA A Fusarium solani f.sp. glycines
}

\author{
VANOLI FRONZA
}

Tese apresentada à Escola Superior de Agricultura "Luiz de Queiroz", Universidade de São Paulo, para obtenção do título de Doutor em Agronomia, Área de Concentração: Genética e Melhoramento de Plantas.

PIRACICABA

Estado de São Paulo - Brasil

Janeiro - 2003 


\title{
GENÉTICA DA REAÇÃO DA SOJA A Fusarium solani f.sp. glycines
}

\author{
VANOLI FRONZA \\ Engenheiro Agrônomo
}

Orientador: Prof. Dr. NATAL ANTONIO VELLO

Tese apresentada à Escola Superior de Agricultura "Luiz de Queiroz", Universidade de São Paulo, para obtenção do título de Doutor em Agronomia, Área de Concentração: Genética e Melhoramento de Plantas.

\author{
PIRACICABA \\ Estado de São Paulo - Brasil \\ Janeiro - 2003
}




\section{Dados Internacionais de Catalogação na Publicação (CIP) DIVISÃO DE BIBLIOTECA E DOCUMENTAÇÃO - ESALQ/USP}

Fronza, Vanoli

Genética da reação da soja a Fusa rium solani f. sp. glyc ines/Vanoli Fronza. - - Piracicaba, 2003.

154 p. : il.

Tese (doutorado) - Escola Superior de Agric ultura Luiz de Queiroz, 2003. Bibliografia.

1. Cruzamentos 2. Genética molecular vegetal 3. Genética quantita tiva 4. Melhoramento genétic o vegetal 5. Podridão-vermelha-da-raiz 6. Resistência àdoença 7. Soja I. Título

CDD 633.34

"Permitida a cópia total ou parcial deste documento, desde que citada a fonte - O autor" 
A minha família e,

principalmente, a minha mãe,

exemplo de trabalho e

de força de vontade,

DEDICO

A minha esposa Rosa,

por me amar incondicionalmente,

pela compreensão e pelo apoio,

como prova de gratidão,

além do meu amor...

OFEREÇO 


\section{AGRADECIMENTOS}

À EPAMIG (Empresa de Pesquisa Agropecuária de Minas Gerais) por ter concedido o meu afastamento para a realização do curso de Doutorado.

Ao Departamento de Genética da ESALQ/USP pela oportunidade concedida para a realização do curso.

Ao CNPq (Conselho Nacional de Desenvolvimento Científico e Tecnológico) pela concessão da bolsa de estudos.

À FAPESP (Fundação de Amparo à Pesquisa do Estado de São Paulo) pelo financiamento de parte do projeto de pesquisa, o que permitiu a concretização deste trabalho.

Ao professor Natal Antonio Vello pela orientação, pelos ensinamentos e, principalmente, pela confiança, o que tornou possível a realização deste trabalho.

Ao professor Luis Eduardo Aranha Camargo pelo estímulo, exemplo de dinamismo e oportunidade de utilizar o Laboratório de Genética Molecular.

Aos colegas do Laboratório de Soja: Fábio Pandini ("in memoriam"), Sandra H. UnedaTrevisoli, Gilberto K. Yokomizo, Cláudio Y. Tsutsumi, Ângela C. A. Lopes, Maurisrael M. Rocha, Maria Clideana C. Maia, Fernando T. S. Miranda, Édina R. Moresco, José F. F. Toledo, Alessandra P. Fávero, Rodrigo L. Brogin, Fábia J. C. B. Maranha e Francisco J. C. Farias, pelo agradável convívio e troca de experiências. Um agradecimento especial à colega Ângela C. A. Lopes pelo fornecimento do arquivo do Excel que serviu de base para o desenvolvimento das planilhas eletrônicas utilizadas para a análise dialélica com os dados da geração $F_{2}$.

Aos colegas do Laboratório de Genética Molecular do Departamento de Entomologia, Fitopatologia e Zoologia Agrícola, cuja lista é extensa demais para citar mas, principalmente, aos seguintes: Maria Teresa G. Lopes, Rodrigo R. Matiello, Viviane F. Rezende, Célia C. Malvas, Jorge O. Gieco, Alessandra S. Penha, Daniela Truffi, Alice M. Quezado-Duval, Ana Paula M. Teixeira e Paulo R. Gagliardi, pelos conhecimentos transmitidos e pelo apoio sempre que solicitados. 
Aos funcionários do Setor de Genética Aplicada às Espécies Autógamas, Marcos C. Nekatschalow, Claudinei A. Didoné e Antônio R. Cogo, e também aos funcionários da Estação Experimental Anhembi, pelo apoio na condução dos experimentos.

Aos funcionários do Departamento de Entomologia, Fitopatologia e Zoologia Agrícola: Fernanda, Rodolfo, Heloísa, Sílvia e Pedro Artuso, pelo apoio quando precisei das instalações e materiais dos seus setores.

Ao Dr. Leones A. Almeida, pelo envio das sementes das cultivares utilizadas nos cruzamentos dialélicos, e ao Dr. José Tadashi Yorinori, pelo envio do isolado SDS-5, ambos pesquisadores da Embrapa Soja (Londrina-PR).

À estagiária Janice I. H. V. Pinto, do curso de Engenharia Agronômica da ESALQ/USP, pelo auxílio durante a condução dos experimentos em telado e casa de vegetação em 2002.

Aos colegas da EPAMIG de Uberaba-MG, Drs. Roberto K. Zito e José Mauro V. Paes, principalmente por assumirem parte dos meus trabalhos em andamento na EPAMIG, facilitando o meu afastamento e contribuindo para minha maior dedicação ao curso.

À professora Maria Lúcia C. Vieira pelo fornecimento do "primer" RAPD.

A todos os professores e funcionários do Departamento de Genética, pelo convívio e atenção dispensada.

Aos colegas de república Diniz Fronza, Éder J. Pozzebon e Manuel A. Navarro Vasquez pelo agradável convívio, companheirismo e troca de experiêcias.

Aos amigos do CENA/USP, Altamir F. Guidolin e família, pelos agradáveis momentos de descontração, e José Carlos F. Resende e família, também colega de EPAMIG.

A todos os colegas e amigos de curso e de ESALQ os quais, para não cometer alguma injustiça, me omitirei de citá-los especificamente.

A minha família, que sempre me apoiou para alcançar os meus objetivos e cuja distância não foi motivo de afastamento.

A todos aqueles que direta ou indiretamente contribuíram para a realização deste trabalho.

Por fm, o meu reconhecimento e um agradecimento muito especial a minha esposa, Rosa Maria da Silva Molina, a qual sempre me apoiou e me ajudou nas horas mais difíceis, sendo uma verdadeira companheira. 


\section{SUMÁRIO}

Página

RESUMO

viii

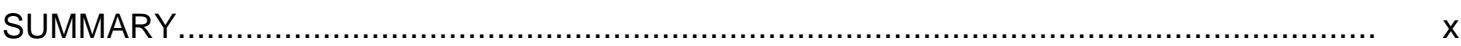

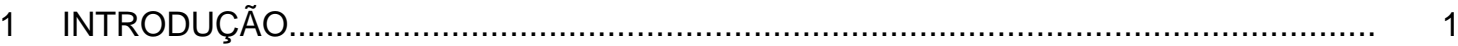

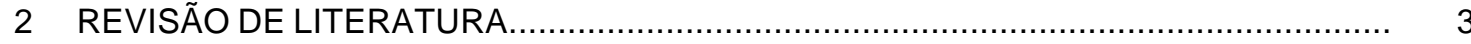

2.1 Distribuição geográfica e importância econômica da PVR ….................................. 3

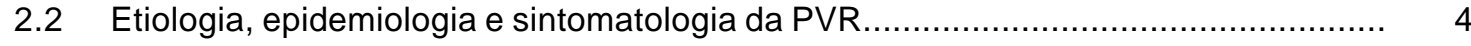

2.3 Métodos para identificação de resistência a PVR .............................................. 6

2.3.1 Utilização de marcadores moleculares........................................................... 8

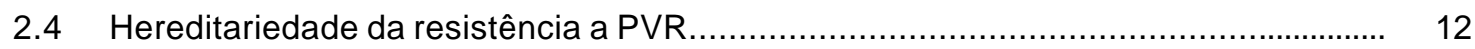

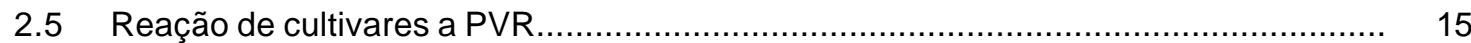

$2.6 \quad$ Análise dialélica de Jinks-Hayman................................................................ 21

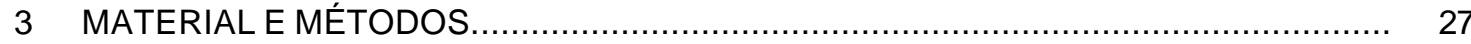

3.1 Estudo da herança da resistência da soja a PVR ............................................. 27

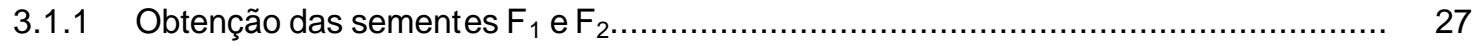

3.1.2 Obtenção e manutenção do isolado do patógeno............................................... 29

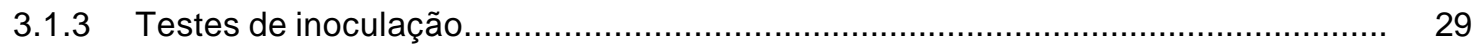

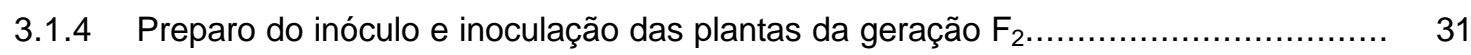

3.1.5 Instalação e condução dos experimentos de inoculação com a geração $F_{2} \ldots \ldots \ldots . .32$

3.1.6 Avaliação dos sintomas da PVR...................................................................... 33

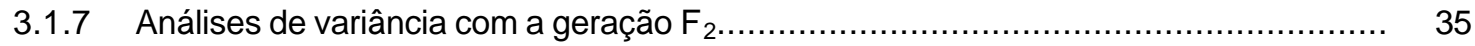

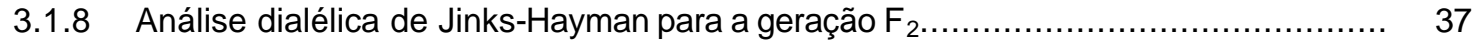

3.1.8.1 Análises de variâncias e covariâncias........................................................... 37

3.1.8.2 Estimativa dos componentes de variação genética...................................... 42

3.1.8.3 Estimativa dos parâmetros genéticos............................................................. 44

3.1.9 Experimento de campo com a geração $F_{3: 2 \ldots \ldots \ldots \ldots \ldots \ldots \ldots \ldots \ldots \ldots \ldots \ldots \ldots \ldots \ldots \ldots \ldots \ldots \ldots \ldots \ldots \ldots \ldots \ldots \ldots \ldots \ldots \ldots \ldots \ldots \ldots \ldots \ldots} \quad 48$

3.2 Utilização de marcadores moleculares................................................................. 49 


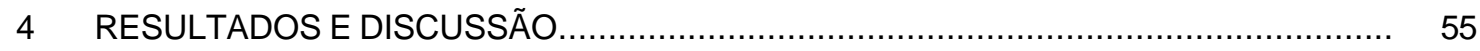

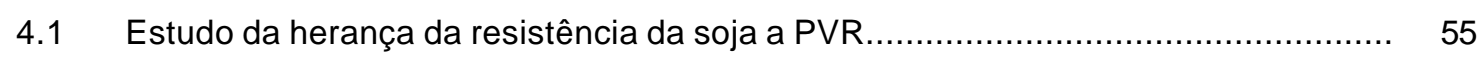

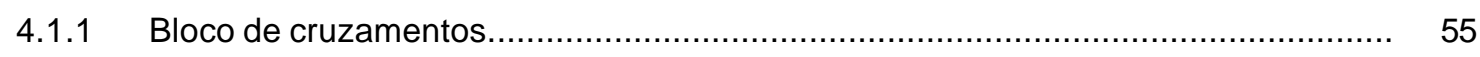

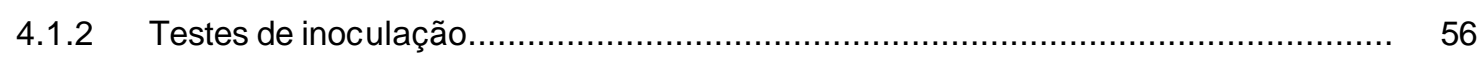

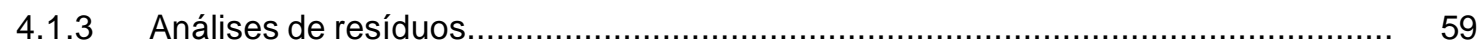

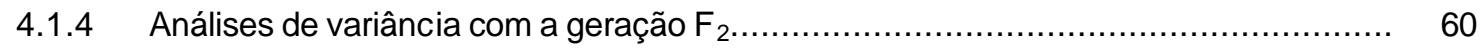

4.1.5 Análise dialélica de Jinks-Hayman com a geração $F_{2} \ldots \ldots \ldots \ldots \ldots \ldots \ldots \ldots \ldots \ldots \ldots \ldots .62$

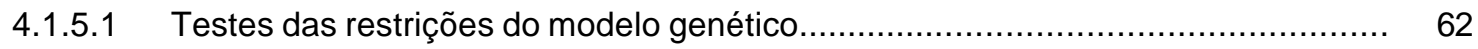

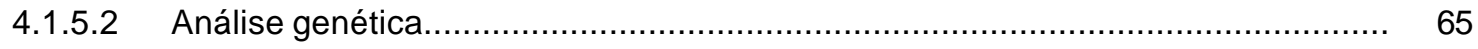

4.1.6 Experimento de campo com a geração $F_{3: 2 \ldots \ldots \ldots \ldots \ldots \ldots \ldots \ldots \ldots \ldots \ldots \ldots \ldots \ldots \ldots \ldots \ldots \ldots \ldots \ldots \ldots \ldots \ldots \ldots \ldots \ldots \ldots \ldots}$

4.2 Utilização de marcadores moleculares......................................................... 81

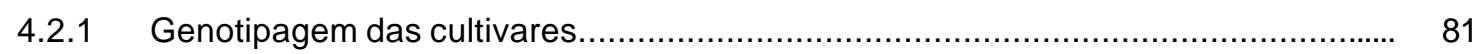

4.2.2 Análise de ligação no cruzamento 'Conquista' x 'Estrela'............................... 83

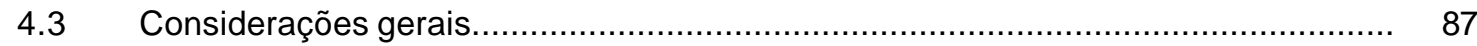

4.4 Estratégias para a utilização da inoculação com grãos de sorgo colonizados com o patógeno para avaliação da resistência da soja a PVR ............................... 92

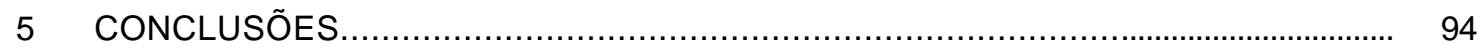

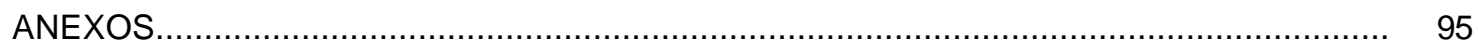

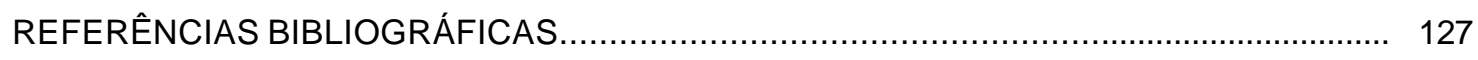

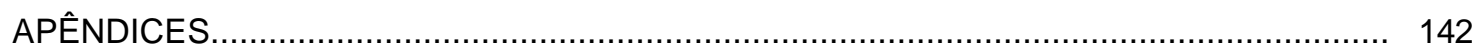




\section{GENÉTICA DA REAÇÃO DA SOJA A Fusarium solanif.sp. glycines}

Autor: VANOLI FRONZA

Orientador: Prof. NATAL ANTONIO VELLO

\section{RESUMO}

Na última década, a podridão vermelha das raízes da soja (PVR), ou síndrome da morte súbita, causada pelo fungo Fusarium solani f.sp. glycines, tornou-se uma doença que é motivo de preocupação para os sojicultores, técnicos e pesquisadores nas regiões onde esta doença já foi constatada, sendo a única estratégia de controle viável a utilização de cultivares resistentes. Diante disto, o principal objetivo do presente trabalho foi o estudo do controle genético da reação da soja a PVR por meio de técnicas de genética clássica e molecular. Foi utilizada a geração $F_{2}$ de um dialelo $5 \times 5$, sem os recíprocos, envolvendo cinco cultivares: Forrest, MG/BR46 (Conquista), IAC-4, FT-Cristalina e FT-Estrela, sendo as duas primeiras mais resistentes a PVR que IAC-4, considerada moderadamente resistente $e$, as duas últimas, altamente suscetíveis. Além de testes de inoculação com as cultivares, foram conduzidos três experimentos com a geração $F_{2}$ : um em telado (semeadura em julho de 2001) e dois em casa de vegetação (semeadura em setembro de 2001 e julho de 2002), sendo os dois primeiros em blocos ao acaso e o terceiro no delineamento inteiramente casualizado. O patógeno foi inoculado com grãos de sorgo colonizados, colocando-se três grãos no fundo de cada cova, no momento da semeadura, fazendo-se cinco covas por vaso, cada qual constituindo uma parcela com cinco plantas. Em cada experimento, foram avaliadas individualmente 50 plantas de cada genitor e 150 plantas de cada cruzamento $F_{2}$, entre os 30 e 40 dias após a emergência, utilizando-se uma escala de notas de 1 a 5 para a severidade dos sintomas foliares da PVR. A porcentagem de incidência da doença em cada parcela e um índice de doença também foram calculados. Nas análises de variância com os dados de médias de parcelas, observaram-se diferenças altamente significativas entre os genitores e entre populações $F_{2}$ para a severidade e índice de doença dos sintomas foliares, na maioria dos casos, embora os genitores resistentes 
e suscetíveis não foram muito contrastantes. As cultivares Forrest e Conquista comportaram-se sempre como resistentes, e Cristalina e Estrela como suscetíveis, enquanto que IAC-4 apresentou comportamento instável. Pela análise dialélica de Jinks-Hayman reafirmou-se a influência do ambiente sobre o controle da resistência à manifestação dos sintomas foliares da PVR, a qual foi controlada quantitativamente. Nos experimentos de 2001, constatou-se apenas a ação de efeitos gênicos aditivos. Porém, no experimento conduzido em telado, a resistência demonstrou controle por genes recessivos, enquanto que na casa de vegetação, na maior parte, por genes dominantes. No experimento de 2002 constatou-se a presença de efeitos gênicos aditivos e de dominância, predominando o efeito destes últimos. Assim, com base no experimento de 2002, para o grupo de cultivares estudado, os parâmetros genéticos calculados permitiram verificar que: o grau médio de dominância indicou a presença de sobredominância; predominaram genes recessivos no grupo dos genitores; pelo menos três locos ou blocos gênicos que exibiram dominância foram responsáveis pelo controle da resistência a PVR; as herdabilidades estimadas no sentido restrito foram médias $(0,33$ a 0,62$)$ e, no sentido amplo, altas $(0,90$ a 0,96), confirmando a presença de dominância; a resistência foi controlada, na maior parte, por genes dominantes e a ordem decrescente de dominância das cultivares foi a seguinte: 'Conquista', 'Cristalina', 'Forrest', 'Estrela' e 'IAC-4'; a exclusão de 'Cristalina', por suspeita de apresentar distribuição de genes correlacionada com 'Conquista' e 'Estrela', melhorou a adequação dos dados de índice de doença ao modelo genético aditivo-dominante de Jinks-Hayman. A utilização de cinco marcadores moleculares microssatélites (Satt163, Satt309, Satt354, Satt371 e Satt570), relatados como ligados a cinco QRLs da PVR, indicou a provável presença de multialelismo nestes locos, o que não invalidou a adequação dos dados ao modelo de Jinks-Hayman. Pela análise de ligação entre 126 indivíduos $F_{2}$ do cruzamento 'Conquista' x 'Estrela' com os marcadores Satt163 e Satt354, no experimento conduzido em telado, houve ligação fraca $(P<0,10)$ entre estes locos e os respectivos QRLs, havendo tendência dos alelos recessivos serem os responsáveis pelo controle da resistência nestes dois locos, concordando com os resultados da análise dialélica para este experimento. 


\title{
GENETICS OF SOYBEAN REACTION TO Fusarium solanif.sp. glycines
}

\author{
Author: VANOLI FRONZA
}

Adviser: Prof. NATAL ANTONIO VELLO

\section{SUMMARY}

In order to study the genetic control of soybean resistance to sudden death syndrome (SDS) by classical and molecular genetic techniques a $5 \times 5$ diallel with the $F_{2}$ generation, without the reciprocals, was carried out. The following parents were used: 'Forrest', 'MG/BR-46 (Conquista)', 'IAC-4', 'FT-Cristalina' and 'FT-Estrela'. The first two cultivars are more resistant to SDS than 'IAC-4', that is considered to be moderately resistant to SDS, and the last two cultivars are highly susceptible. Tests of inoculation were done with the cultivars and three experiments with the $F_{2}$ generation (two in 2001 and one in 2002) were carried out, all of them in greenhouses. The fungus was inoculated by three colonized sorghum grains placed at the bottom of the holes at the planting. It was used five-holes/clay pot, which one was considered a plot with five plants. In each experiment with the $F_{2}$ generation 50 single plants of each parent and 150 single plants of each $F_{2}$ population were evaluated between 30 and 40 days after emergency by using a scale ( 1 to 5 ) based on foliar severity symptoms. The disease incidence and a disease index also were calculated for each plot. In the ANOVAs with data plot average for severity and disease index highly significant differences were detected among the treatments in almost all cases, although the resistant and the susceptible parents did not differ too much. The parents 'Forrest' and 'Conquista' were always more resistant than the others. 'Cristalina' and 'Estrela' were the most susceptible parents, while 'IAC-4' was unstable. Jinks-Hayman's analysis reaffirmed the environment effect on the genetic control of the resistance to SDS foliar symptoms, which was quantitatively controlled. In the 2001 experiments there was observed only additive genic effects, but in one experiment recessive genes had controlled the resistance, while in the other, in major part, dominant genes had controlled the resistance to SDS. In the 2002 experiment it was showed mainly dominance effects and also some additive genic effects. 
In the last experiment, for the group of parents used, the genetic parameters indicated that: the average degree of dominance showed the presence of overdominance; there were more recessive than dominants genes in the group of the parents; at least three loci or genic blocks that exhibited dominance were responsible for the genetic control of the resistance to SDS; the heritability in the narrow-sense had middle values (0.33 to 0.62$)$, and in the broad-sense had high values (0.90 to 0.96$)$, reinforcing the presence of dominance effects; the resistance to SDS was controlled, mostly, by dominant genes; the decreasing order of dominance of the parents were: 'Conquista', 'Cristalina', 'Forrest', 'Estrela' and 'IAC-4'; and the exclusion of 'Cristalina' of the diallel for disease index by suspect of gene correlated distribution with 'Conquista' and 'Estrela' improved the fitting of the data to Jinks-Hayman's additive-dominant model. Five microsatellite markers (Satt163, Satt309, Satt354, Satt371 and Satt570), reported as linked to five SDS QRLs, were used and showed the possibility of occurrence of multiallelism in those loci, but this evidence did not invalidate the fitting of the data to Jinks-Hayman's model. The molecular analysis in 126 plants of 'Conquista' $x$ 'Estrela' cross with the markers Satt163 and Satt354, in the first experiment of 2001, showed the tendency of weakly association $(P<0,10)$, between those loci and the QRLs. This analysis showed also tendency that the recessive genes controlled the resistance to SDS in both loci, in according to the results obtained in the diallel analysis for this experiment. 


\section{INTRODUÇÃO}

Cultivares de soja foram desenvolvidas para diferentes latitudes e os mais variados tipos de solo e condições climáticas, porém, a exploração econômica do seu potencial produtivo, o qual permite rendimentos superiores a $4.000 \mathrm{~kg} / \mathrm{ha}$, dificilmente é alcançada pelos agricultores.

Entre os principais fatores limitantes à obtenção de elevados rendimentos, está a ocorrência de doenças, sendo que, cerca de 40 doenças da soja já foram identificadas no Brasil, abrangendo aquelas provocadas por fungos, bactérias, vírus e nematóides (Empresa Brasileira de Pesquisa Agropecuária - Embrapa, 2001).

A podridão vermelha das raízes da soja (PVR) ou síndrome da morte súbita ("sudden death syndrome"), causada pelo fungo Fusarium solani f.sp. glycines, é uma destas doenças e, embora já ocorresse em algumas áreas no Brasil desde a década de 80 , somente a partir dos anos 90 é que passou a causar prejuízos maiores, sendo o uso de cultivares resistentes a melhor expectativa de controle da PVR e de convivência com o patógeno causador da doença. Pela provável natureza poligênica do controle da resistência e pela grande influência do ambiente na intensidade de manifestação dos sintomas, aliados ao fato da inexistência de um método de controle químico ou cultural eficiente, a PVR tornou-se, sem dúvida, uma grande preocupação para os sojicultores, técnicos e pesquisadores nas regiões onde sua ocorrência já foi constatada.

Como a ocorrência da PVR foi detectada inicialmente nos Estados Unidos, vários trabalhos já foram desenvolvidos naquele País visando desenvolver métodos eficientes de avaliação, identificar fontes de resistência e também para đucidar os mecanismos envolvidos na resistência. Entretanto, ainda restam muitas dúvidas para uma melhor compreensão da genética das interações patógeno-hospedeiro deste patossistema, além de que, são poucos os trabalhos realizados no Brasil, utilizando-se cultivares aqui desenvolvidas.

Além disso, a avaliação da reação de genótipos de soja a Fusarium solani f.sp. glycines, patógeno causador da PVR, tanto em experimentos de campo quanto em casa de vegetação, é dificultada por sofrer forte influência do ambiente, o qual reduz a precisão experimental e também ocasiona a ocorrência de escapes. Desta forma, a utilização de 
marcadores moleculares torna-se bastante promissora, não só para aumentar a eficiência de seleção de genótipos resistentes a PVR, mas também para auxiliar na escolha de genitores com maior grau de resistência ou apresentando diferentes genes de resistência, visando o acúmulo destes em seus descendentes. Por outro lado, a utilização de marcadores moleculares ligados aos genes de interesse também pode auxiliar na verificação das restrições impostas para a aplicação de análises dialélicas, como a metodologia de Hayman, no estudo da herança da resistência a PVR, assim como para confirmar certos resultados obtidos. Neste sentido, não se encontrou na literatura nenhum trabalho envolvendo cruzamentos dialélicos para o estudo da resistência a PVR.

Diante disto, com os resultados a serem obtidos com o presente trabalho, espera-se contribuir para aumentar a eficiência dos programas de melhoramento da cultura que visem incorporar resistência a esta doença nas suas cultivares, tendo como principais objetivos os seguintes:

- Estudar o controle genético da reação da soja a PVR, causada pelo fungo $F$. solani f.sp. glycines, com ênfase no tipo de herança e número mínimo de genes envolvidos;

- Identificar genótipos com maior grau de resistência a PVR;

- Avaliar o método dos grãos de sorgo colonizados com o patógeno para discriminação da reação de genótipos a PVR utilizando inoculação artificial;

- Avaliar a eficiência de marcadores moleculares microssatélites, citados na literatura como ligados a QRLs (locos controladores de resistência quantitativa) da PVR, para a identificação de genótipos resistentes a doença. 


\section{REVISÃO DE LITERATURA}

\subsection{Distribuição geográfica e importância econômica da PVR}

A podridão vermelha das raízes da soja (PVR) é conhecida nos Estados Unidos como síndrome da morte súbita ("sudden death syndrome-SDS") e está amplamente disseminada nas regiões em que a soja é cultivada naquele País.

Esta doença foi observada pela primeira vez no estado de Arkansas, em 1971, onde se restringiu até 1984, quando sua ocorrência também foi constatada nos estados do Mississippi, Missouri, Kentucky e Tennessee (Roy et al., 1989). Posteriormente, sua presença também foi notificada em Illinois (Eathington et al., 1993), Kansas (Jardine \& Rupe, 1993) e lowa (Yang \& Rizvi, 1994), entre outros Estados de ocorrência mais recente.

Até meados da década de 90, além dos Estados Unidos, a PVR só era encontrada na Argentina e no Brasil, causando prejuízos consideráveis aos sojicultores, principalmente nos dois primeiros países. Posteriormente, foi identificada também no Canadá (Anderson, 1998) e, na safra de outono-inverno de 2001, foi constatada pela primeira vez na Bolívia (Yorinori, 2002). No ano de 1994, as perdas estimadas foram de 89.400 t nos EUA e 134.400 t na Argentina (Wrather et al., 1997), equivalendo a, aproximadamente, US\$20 milhões e US\$ 30 milhões (a US\$220.00/t), respectivamente. Atualmente, a PVR é considerada a segunda doença de maior importância na Argentina (Yorinori, 2002).

No Brasil, a PVR foi observada pela primeira vez em São Gotardo-MG, na safra 1981/82 (Yorinori, 1997). Porém, somente a partir das safras 1990/91 e 1991/92 é que sua freqüência nas lavouras se elevou (Yorinori et al., 1993), disseminando-se também para o Distrito Federal e os estados de Goiás, Mato Grosso, Mato Grosso do Sul, Paraná, Santa Catarina e Rio Grande do Sul (Yorinori, 1997), além da Bahia e São Paulo (Embrapa, 2001). Isto indica que a PVR está se tornando uma doença importante nos Estados da região Sul e nas áreas de cerrado com maior altitude. Com relação às perdas no rendimento de grãos, estas já atingiram até $40 \%$ em algumas lavouras brasileiras (Wrather et al., 1997). Na safra 1994/95, as perdas provocadas pela doença no Brasil foram estimadas em $15.000 \mathrm{t}$, equivalendo a US\$ 3.2 milhões (Yorinori, 1997). Em levantamentos feitos em diversas 
propriedades e áreas experimentais na safra 1996/97, a incidência da PVR, avaliada pela porcentagem de plantas mortas ou com raízes atacadas, alcançou níveis de até $100 \%$, com as perdas variando de insignificantes a mais de $30 \%$ (Yorinori \& Hiromoto, 1998). Segundo Gásperi (2000), comparando-se parcelas experimentais de plantas sintomáticas com assintomáticas, em quatro lavouras comerciais, as perdas no rendimento de grãos variaram de 29 a 51\%, enquanto o peso de mil sementes sofreu reduções de 6 a 19\%. Em levantamento feito na safra 1999/2000, estimaram-se perdas de US\$ 52.9 milhões e uma área afetada de mais de 2 milhões de hectares (Yorinori, 2002). Pela dificuldade de controle, o autor comentou que, atualmente, a PVR é a doença mais preocupante na cultura da soja no Brasil, colocando-a até mesmo à frente da ferrugem asiática da soja, causada pelo fungo Phakopsora pachyrhizi, a qual é considerada a doença mais temida em termos mundiais e, cuja ocorrência, foi constatada no Brasil na safra 2000/01.

\subsection{Etiologia, epidemiologia e sintomatologia da PVR}

O agente causal da PVR (Yorinori et al., 1993; Yorinori, 1994; Yorinori \& Nomura, 1994; Costa \& Yorinori, 1995a e 1995b), inicialmente, foi designado como Fusarium solani forma A ou FSA (Roy et al., 1989). Posteriormente, o F. solani forma A foi classificado como F. solani (Mart.) Sacc. f.sp. glycines Roy, pela avaliação detalhada de suas características morfológicas e associação com a PVR (Roy, 1997). A análise com marcadores moleculares RAPD também já havia indicado que os isolados que causam a PVR na soja formavam um subgrupo biologicamente importante dentro de F. solani f.sp. phaseoli e que poderiam representar uma forma separada dentro da espécie (Achenbach et al., 1996).

Em comparação com $F$. solani forma B (FSB), a forma A (FSA) apresenta as seguintes diferenças morfológicas principais (Roy et al., 1989): a) Em meio BDA, FSA produz micélio branco-acinzentado, o qual é mais esparso do que o de FSB; b) A coloração azulada na parte central da colônia é típica nas colônias de culturas mais novas de FSA, enquanto que FSB produz micélio flocoso, de coloração branco-acinzentada, dando uma cor creme a bronzeada ao meio; c) Os macroconídios de FSA são formados em conidióforos simples ou ramificados em monofiálides, sendo mais longos do que os de FSB; d) Os microconídios são raros em FSA, mas predominam em FSB, no qual são formados ao longo de conidióforos pouco ou nãoramificados em monofiálides e formam "falsas-cabeças" de microconídios, não observadas em FSA.

Segundo Roy et al. (1997), a fase sexuada de F. solani f.sp. glycines ainda não era conhecida. Porém, esta havia sido erroneamente identificada como Nectria haematococca, 
conforme constatado anteriormente por O'Donnel \& Gray (1995), os quais utilizaram marcadores moleculares.

A existência de diferentes raças do patógeno causador da PVR tem sido motivo de intensa especulação, porém, ainda não há nenhuma evidência convincente da sua ocorrência. Achenbach et al. (1996), utilizando marcadores RAPD, encontraram 100\% de similaridade genética entre 22 diferentes isolados causadores da PVR procedentes de várias regiões dos Estados Unidos. Da mesma forma, Achenbach et al. (1997) concluíram que os isolados causadores da PVR coletados nos Estados Unidos compreendiam uma população quase clonal, com nível extremamente baixo de variação genética entre os indivíduos. No Brasil, Costa \& Yorinori (1997) observaram variações morfológicas e de esporulação entre diferentes isolados, mas testes de inoculação não demonstraram diferenças na patogenicidade entre as formas variantes. Por outro lado, tem sido constatada variação na agressividade entre diferentes isolados (Melgar \& Roy, 1994; Gray \& Achenbach, 1996; Huang \& Hartman, 1998; Gásperi, 2000; Scandiani et al., 2002). Diferenças na porcentagem de germinação de macroconídios entre diferentes isolados também já foram relatadas (Li et al., 1998). Desta forma, torna-se importante a definição adequada do isolado a ser utilizado em inoculações artificiais para avaliar a resistência de genótipos de soja a PVR.

Quanto a outros hospedeiros, além da soja, entre 21 espécies avaliadas, apenas o feijão mungo (Vigna radiata) apresentou sintomas quando inoculado com FSA pelo método dos grãos de aveia colonizados com o patógeno; por outro lado, utilizando o método do palito de dente, além do feijão mungo, o feijão comum (Phaseolus vulgaris), feijão fava ( $P$. lunatus) e o caupi (V. unguiculata) também desenvolveram sintomas da doença (Melgar \& Roy, 1994). Isto demonstra a grande especificidade de $F$. solani f.sp. glycines (FSA), o qual poderia ser derivado de F.solani f.sp. phaseoli como consequência de mutações ocorridas em regiões genômicas responsáveis pela identificação do hospedeiro, alterando sua patogenicidade.

Estruturas de resistência na forma de clamidosporos, localizadas no solo ou em restos culturais, constituem o inóculo primário da doença (Roy et al., 1997). O modo de penetração do fungo nas raízes ainda não foi bem esclarecido mas, provavelmente, seja de forma direta, isto é, a penetração ocorreria durante a germinação de clamidosporos ou de macroconídios que entram em contato com o sistema radicular das plantas. Nas raízes, o sintoma primário de infecção da doença é uma mancha avermelhada, mais visível na raiz principal e, geralmente, localizada logo abaixo da superfície do solo; com a evolução da doença, a coloração dessa mancha passa de vermelho-arroxeada para castanho-avermelhada a quase negra, circundando a raiz (Yorinori et al., 1993). Ainda segundo estes autores, essa mancha, a qual representa uma necrose acentuada, localiza-se mais no tecido cortical da raiz, enquanto que o lenho adquire, no máximo, coloração castanho-clara, a qual também se estende pela haste principal, vários 
centímetros acima do nível do solo, havendo, nessa fase, amarelecimento precoce das folhas, observando-se necrose internerval acentuada (folha "carijó"). Tanto as raízes de cultivares suscetíveis quanto aquelas de cultivares resistentes são infectadas pelo patógeno, porém, a taxa de infecção e o desenvolvimento dos sintomas foram menores nos genótipos resistentes (Njiti et al., 1997a). No final do ciclo de plantas severamente infectadas, é possível se observar uma massa de macroconídios azuis a verde-azulados nas raízes, próximo à superfície do solo, principalmente nos períodos com elevado teor de umidade (Roy et al., 1997).

Os sintomas foliares a campo, geralmente, desenvolvem-se durante o florescimento ou logo após este e os primeiros sintomas são manchas de forma circular a irregular, dispersas, internervais, verde pálidas a cloróticas e com tamanho de poucos milímetros ou mais, produzindo um aspecto mosqueado; estas manchas podem aumentar de tamanho e se tornarem necróticas ou podem coalescer e formar regiões alongadas de clorose internerval; podendo também ocorrer completo desfolhamento quando a doença for severa; além disso, a infecção severa durante o florescimento e a formação de vagens pode resultar no aborto de flores e vagens (Roy et al., 1997). O número de vagens por planta é reduzido somente quando a severidade da doença atinge níveis moderados a severos (Hershman et al., 1990). Reduções no peso de cem sementes e na altura da planta também foram observadas (McLean \& Lawrence, 1993). As perdas em termos de rendimento de grãos, basicamente, são devidas à redução no número de vagens com sementes e no peso das sementes (Njiti et al., 1998b; Gásperi, 2000).

Condições de alta umidade do solo (cerca de $-0,003$ a $-0,01 \mathrm{MPa}$ ) e temperaturas amenas foram favoráveis ao desenvolvimento da doença, sendo que temperaturas em torno de $15^{\circ} \mathrm{C}$ favoreceram o desenvolvimento dos sintomas nas raízes e, entre 22 a $24^{\circ} \mathrm{C}$, na parte aérea (Scherm \& Yang, 1996). Assim, áreas irrigadas ou com maior altitude parecem ser mais sujeitas à incidência da doença. $O$ efeito da temperatura também é importante para a germinação dos macroconídios, a qual não ocorre a $4^{\circ} \mathrm{C}$ e é maior a $25^{\circ} \mathrm{C}$ do que a 20 ou $30^{\circ} \mathrm{C}$ (Li et al., 1998). Embora vários fatores químicos e físicos do solo estejam associados com a incidência da PVR, freqüentemente, tem-se observado que a doença é mais severa nas áreas mais produtivas (Rupe, 1999).

\subsection{Métodos para identificação de resistência a PVR}

Por ser causada por um fungo de solo e pela expressão dos sintomas sofrer muita influência das condições edáficas e climáticas, muitos pesquisadores têm avaliado a reação de genótipos a PVR no próprio campo, instalando experimentos em diversos locais. Outros, porém, 
têm utilizado diversas metodologias de inoculação artificial e avaliação dos sintomas em ambientes controlados. No entanto, uma metodologia precisa e segura ainda não foi desenvolvida, havendo controvérsias na indicação do método mais adequado para a avaliação em programas de melhoramento visando desenvolver cultivares mais resistentes a PVR.

Quando se trabalha em campo infestado naturalmente, a expressão dos sintomas é mais lenta, pela menor pressão de inóculo. Segundo Rupe et al. (1991), em $P_{3}$ foi possível observar diferenças significativas entre genótipos, porém, estas foram mais distintas em $\mathrm{R}_{6}$. Njiti et al. (1996) utilizaram RILs (linhagens endogâmicas recombinantes) $F_{7: 6}$ e observaram interação genótipo $x$ ambiente significativa, sugerindo testes em vários locais para a seleção efetiva de resistência estável a PVR.

Em casa de vegetação ou câmaras de crescimento, a principal diferença entre os métodos de avaliação é a forma de se proceder à inoculação artificial, sendo os métodos encontrados na literatura os seguintes:

a) Grãos de aveia colonizados (Lim, 1991; Stephens et al., 1993a, 1993b e 1993c; Melgar \& Roy, 1994; Torto et al., 1996; Nelson et al., 1997);

b) Grãos de sorgo colonizados (Ringler \& Nickell, 1996; Hartman et al., 1997; Huang \& Hartman, 1998; Balardin \& Rubin, 1999);

c) Micélio em palito de dente (Melgar \& Roy, 1994; Costa \& Yorinori, 1995a e 1995b; Leão et al., 1998; Klingelfuss et al., 2001a e 2001b);

d) Suspensão de micélio/conídios (Costa \& Yorinori, 1995a; Heavner et al., 1996);

e) Farinha de milho (fubá) e areia (Killebrew et al., 1988; Roy et al., 1989; McLean \& Lawrence, 1993; Torto et al., 1996; Njiti et al., 1997b e 2001);

f) Imersão das raízes em suspensão de conídios (Costa \& Yorinori, 1995a).

O uso de grãos de sorgo colonizados para se proceder à inoculação durante a semeadura tem reduzido a variabilidade dos resultados, tornando possível a realização de análises de rotina em casa de vegetação, porém, é imprescindível que as sementes de soja não fiquem em contato direto com o inóculo, porque a podridão radicular excessiva impede 0 crescimento suficiente das plantas para permitir o desenvolvimento de sintomas foliares típicos da PVR (Rupe, 1999). Desta forma, este é o método que se apresenta como o mais promissor para a avaliação de genótipos utilizando inoculação artificial. Este método é uma modificação daquele que utiliza grãos de aveia (Lim, 1991), substituindo-os por sorgo e procedendo-se à inoculação das plântulas aos 20 dias após a semeadura (estádio $V_{2}$ ), utilizando-se dois grãos de sorgo/plântula, os quais foram colocados cerca de $2 \mathrm{~cm}$ abaixo da superfície do solo, próximo da raiz principal, com o auxílio de uma faca (para abrir uma fenda no solo) ou de uma colher (para escavar o solo), tomando-se o cuidado para não atingir as raízes e de cobrir os grãos de sorgo com solo (Ringler \& Nickell, 1996). Hartman et al. (1997) e Huang \& Hartman 
(1998) também apresentaram detalhes desta metodologia, só que procederam à inoculação durante a semeadura, realizada em bandejas $(8 \times 12 \mathrm{~cm})$, colocando $5 \mathrm{~cm}^{3}$ de grãos de sorgo colonizados com o patógeno em $12 \mathrm{~cm}$ de sulco (com $2 \mathrm{~cm}$ de profundidade e espaçamento entre sulcos de $3 \mathrm{~cm}$ ), e após adicionaram $800 \mathrm{~cm}^{3}$ de solo esterilizado, refizeram os sulcos, colocaram as sementes de soja e as cobriram com outros $800 \mathrm{~cm}^{3}$ de solo. Em vez de colocar o inóculo em sulcos, Balardin \& Rubin (1999) utilizaram seis grãos de sorgo para cada semente de soja ou cova, colocando-as $2 \mathrm{~cm}$ abaixo das sementes no momento da semeadura. Posteriormente, foi sugerido o uso de apenas três grãos de sorgo por cova (Balardin ${ }^{1}$ ).

Além de avaliações a campo ou em casa de vegetação, também pode ser feita a avaliação em laboratório, utilizando cultivo "in vitro" de calos ou cotilédones na presença da toxina do fungo (Lim et al., 1990; Jin et al., 1996a e 1996b; Huang \& Hartman, 1998). A caracterização e purificação de uma fitotoxina, um polipeptídeo fitotóxico com peso molecular estimado em $17 \mathrm{Ka}$, produzida somente por isolados de F. solani que causam a PVR, foi efetuada por Jin et al. (1996a). Segundo Huang \& Hartman (1998), há fortes indícios de que a capacidade destes isolados, em causar os sintomas foliares típicos da PVR, seja devida, pelo menos em parte, àprodução de um polipetídeo fitotóxico.

Marcadores moleculares também podem ser utilizados, conforme comentado a seguir.

\subsubsection{Utilização de marcadores moleculares}

A seleção de genótipos superiores com o auxílio de marcadores moleculares representa o coroamento da associação entre o melhoramento dito convencional e as modernas técnicas de biologia molecular disponíveis atualmente.

Esta metodologia apresenta enormes potencialidades de uso na seleção de genótipos resistentes a doenças, principalmente aquelas provocadas por patógenos de solo e/ou controladas por mecanismos de resistência complexa no hospedeiro, como é o caso da PVR.

$\mathrm{Na}$ resistência de natureza poligênica, os genes não podem ser acompanhados individualmente pela genética biométrica, mas apenas coletivamente, daí a importância do uso de marcadores moleculares para a detecção de QTLs ("quantitative trait loci" - locos controladores de caracteres quantitativos). Estes QTLs, ou QRLs ("quantitative resistance loci" locos controladores de resistência quantitativa), são regiões cromossômicas que contêm genes quantitativos, os quais contribuem com diferentes efeitos, para o controle genético da resistência a uma ou mais doenças; porém, com o uso de marcadores moleculares, é possível

${ }^{1}$ BALARDIN, R.S. (Universidade Federal de Santa Maria. Centro de Ciências Rurais, Departamento de Defesa Fitossanitária, Santa Maria). Comunicação pessoal, 1999. 
isolar o efeito de cada QRL e estudar a sua segregação mendeliana (3:1).

Resumidamente, o uso de marcadores moleculares para se proceder ao mapeamento de QRLs e sua posterior utilização em seleção auxiliada por marcadores ("MAS - marked assisted selection"), visando resistência a doenças, envolve as seguintes etapas:

1) Fenotipagem: avaliação da resistência (reação) à doença em população segregante $\left(F_{2}\right.$ e/ou famílias $F_{3: 2}$, retrocruzamento, linhagens dihaplóides, linhagens endogâmicas recombinantes"RILs" ou linhagens quase isogênicas-"NILs") inoculada com o patógeno;

2) Genotipagem: discriminação das plantas pelo seu genótipo, inferido com base no uso de marcadores moleculares, previamente selecionados por serem polimórficos para os genitores envolvidos no cruzamento que originou a população segregante em estudo;

3) Análise estatística dos resultados: utilização de programas de computador para avaliar a existência de ligação entre os locos do marcador molecular e de resistência àdoença.

Vários tipos de marcadores moleculares já foram utilizados em trabalhos envolvendo a identificação de QRLs associados ao controle da resistência a PVR em soja:

- RFLP ("Restriction Fragment Length Polymorphism" - polimorfismo no comprimento de fragmentos de restrição) e RAPD ("Random Amplified Polymorphic DNA" - polimorfismo de DNA amplificado ao acaso) (Abu-Thredeih et al., 1996; Chang et al., 1996; Hnetkovsky et al., 1996; Chang et al., 1997; Kilo et al., 1997; Njiti et al., 1998a; lqbal et al., 2001);

- Microssatélites ou SSR ("Single Sequence Repeat" - seqüências simples repetidas) (Abu-Thredeih et al., 1996; Chang et al., 1997; Kilo et al., 1997; Bell-Johnson et al., 1998; Prabhu et al., 1999; Iqbal et al., 2001; Njiti et al., 2002);

- AFLP ("Amplified Fragment length Polymorphism"- polimorfismo no comprimento de fragmentos amplificados) (Abu-Thredeih et al., 1996; Njiti et al., 2002);

- SCAR ("Sequence Characterized Amplified Regions" - regiões amplificadas caracterizadas por seqüência) (Prabhu et al., 1997).

Entre os diversos trabalhos realizados, na Tabela 01 estão apresentados os marcadores ligados a QRLs da PVR encontrados na literatura e as características associadas.

Os marcadores moleculares também podem ser utilizados para a identificação de isolados do patógeno causador da PVR (Achenbach et al., 1996 e 1997; Rupe et al., 2001), permitindo a construção de dendrogramas e posterior análise da similaridade genética.

Para a identificação de marcadores moleculares ligados aos QRLs associados ao controle da resistência a PVR em soja, o primeiro passo é a fenotipagem das plantas. Na maior parte dos trabalhos citados na literatura, esta etapa foi efetuada em experimentos de campo (Chang et al., 1996 e 1997; Hnetkovsky et al., 1996; Doubler et al., 1997; Kilo et al., 1997; Njiti et al., 1998a e 2002; Meksem et al., 1999a; Prabhu et al., 1999; lqbal et al., 2001). Somente os trabalhos de Torto et al. (1996) e de Njiti et al. (1997b) fazem referência ao uso de experimentos 
em casa de vegetação para a realização desta etapa, porém, os primeiros autores não encontraram correlação entre os marcadores detectados nos experimentos de casa de vegetação (inoculados tanto pela técnica dos grãos de aveia colonizados como por farinha de milho e areia colonizados) e campo. Ao contrário, Njiti et al. (1997b) encontraram correlação positiva, embora também tenham utilizado a técnica de inoculação por farinha de milho e areia, porém, somente na menor concentração de inóculo utilizada $\left(1: 120\right.$, ou cerca de $3,3 \times 10^{3}$ hifas $/ \mathrm{cm}^{3}$ versus $1: 40$, ou cerca de $10^{4}$ hifas $/ \mathrm{cm}^{3}$ no trabalho de Torto et al., 1996).

$\mathrm{Na}$ maioria dos trabalhos, a avaliação fenotípica foi efetuada utilizando-se RILs, normalmente derivadas de plantas $\mathrm{F}_{5}$, sendo o cruzamento 'Forrest' $\mathrm{x}$ 'Essex' o mais estudado (Abu-Thredeih et al., 1996; Chang et al., 1996 e 1997; Hnetkovsky et al., 1996; Torto et al., 1996; Prabhu et al., 1999; lqbal et al., 2001), inclusive utilizando-se NILs ("near isogenic lines" linhagens quase isogênicas) deste mesmo cruzamento, como nos trabalhos de Doubler et al. (1997) e Njiti et al. (1998a). O cruzamento 'Forrest' x 'Essex' é o mais utilizado porque 'Essex' é suscetível a PVR e ao NCS (nematóide de cisto da soja, Heterodera glycines Ichinohe), enquanto que 'Forrest' é tida como resistente a PVR e à raça 3 de NCS. RILs também foram utilizadas no estudo de outros cruzamentos, como por exemplo 'Pyramid' (moderadamente resistente a PVR e resistente às raças 3 e 14 de NCS) x 'Douglas' (suscetível a PVR e ao NCS) (Abu-Thredeih et al., 1996; Kilo et al., 1997; Njiti etl., 2002) e 'Hartwig' (parcialmente resistente a PVR e resistente a todas as raças conhecidas de NCS nos EUA) x 'Flyer' (suscetível a PVR e ao NCS) (Prabhu et al., 1999).

Para a etapa de genotipagem, os marcadores microssatélites, pelas suas vantagens, principalmente o elevado grau de polimorfismo, parecem apresentar maior potencialidade de uso em programas de melhoramento genético nos quais se pretende utilizar a seleção auxiliada por marcadores moleculares para a discriminação de genótipos resistentes a PVR. Pela importância da cultura da soja, uma das grandes limitações deste método, ou seja, a disponibilidade de "primers" microssatélites, cujo desenvolvimento é bastante trabalhoso, já foi superada. Uma lista bastante completa de "primers", com as respectivas seqüências, é encontrada no site http://129.186.26.94/ssr.html, no qual mais de 600 "primers" estão listados. A síntese destes "primers" já está sendo feita no Brasil e a sua encomenda também pode ser feita via "internet". Cregan et al. (1999) publicaram um mapa de ligação integrando 26 locos marcadores clássicos e marcadores moleculares RFLP (689 locos), RAPD (79 locos) e microssatélites (606 locos), o que também auxilia muito o trabalho com os marcadores microssatélites.

A última etapa compreende a análise estatística dos dados coletados durante as etapas de fenotipagem e genotipagem para avaliar as correlações existentes. Para determinar se existe ligação genética entre marcadores e QTLs é necessário haver desequilíbrio de ligação 
entre os alelos no loco marcador e alelos do QTL, o que é interpretado como evidência de ligação física entre os dois locos (Ferreira \& Grattapaglia, 1998). A detecção de QTLs associados com resistência quantitativa pode ser feita pela análise de variância, desde que se utilize o teste $F$ com $P<0,001$, para minimizar a aceitação de falsas associações (Lander \& Botstein, 1989). A análise de QTLs também pode ser feita pela análise de regressão, com um marcador de cada vez ("Single Point Analysis" - Análise de Marcas Individuais), conforme utilizado por Tanksley et al. (1982), ou com grupos de marcadores ligados analisados simultaneamente ("Interval Analysis" - Mapeamento por Intervalo), como proposto por Lander \& Botstein (1989). Porém, pelas limitações destes dois métodos, foi proposto o Mapeamento por Intervalo Composto (“Composite Interval Mapping”), o qual, além dos marcadores que flanqueiam o intervalo, considera também outros marcadores, fora do intervalo, pela utilização de um modelo de regressão múltipla, proporcionando maior resolução no mapeamento de QTLs (Zeng, 1994). Um método ainda mais aprimorado é o Mapeamento por Intervalo Múltiplo ("Multiple Interval Mapping"), proposto por Kao et al. (1999), o qual considera os efeitos da epistasia entre os QTLs detectados e proporciona também a estimativa dos efeitos aditivos e de dominância de cada QTL. Assim, sem dúvidas, atualmente se dispõe de métodos com grande capacidade de detecção de QTLs, diminuindo o risco da deteç̧ão de QTLs "fantasmas", ou seja, de falsos QTLs.

A seleção auxiliada por marcadores para identificar genótipos resistentes a PVR e ao NCS, no caso com microssatélites, já é utilizada no programa de melhoramento conduzido na Universidade do Sul de Illinois-Carbondale, IL, EUA, desde 1997, quando foram avaliados 10.000 genótipos com esta técnica, sendo prevista a avaliação de 100.000 genótipos no ano seguinte (Bell-Johnson et al., 1998). Segundo Prabhu et al. (1999), para a PVR, o custo da seleção por marcadores moleculares foi de US\$1.00 por genótipo, mais seis minutos de mãode-obra. Segundo estes autores, utilizando-se apenas um marcador (Satt038) e a média de severidade de infecção nas raízes de até $30 \%$ (igual a média do genitor resistente) para um genótipo ser considerado resistente para a seleção fenotípica, a eficiência de seleção foi de 78\% entre RILs $\mathrm{F}_{6: 5}$ do cruzamento 'Hartwig' x 'Flyer'.

Embora este resultado seja bastante animador, provavelmente, a porcentagem de eficiência da seleção com este mesmo marcador em outros cruzamentos deverá variar bastante. Esta variação irá depender, principalmente, da porcentagem da variação fenotípica da resistência explicada por este marcador e da distância (em $\mathrm{cM}$ ) entre o loco do marcador e o loco que controla a resistência a doença em plantas derivadas de outros cruzamentos. Desta forma, pelos valores de $r^{2}$ observados na Tabela 01, provavelmente, será necessária a utilização de, pelo menos, dois marcadores, fortemente ligados aos QRLs que controlam a resistência a PVR, para se obter uma maior eficiência de seleção em programas que visem o 
desenvolvimento de cultivares resistentes a PVR, pela utilização da seleção auxiliada por marcadores moleculares.

\subsection{Hereditariedade da resistência a PVR}

Pelo fato da PVR ser causada por um fungo de solo, o estudo da reação das plantas ao ataque do patógeno é bastante difícil. Diante disto, vários trabalhos foram realizados utilizandose diversos métodos de inoculação, além de avaliações a campo e também pelo uso de marcadores moleculares, como visto anteriormente.

Além da própria característica do patógeno, a determinação da resistência a PVR também é dificultada por ser considerada do tipo incompleta (parcial), de natureza poligênica e por ser influenciada pelo ambiente. No entanto, em um dos primeiros estudos da herança da resistência a PVR, utilizando-se populações segregantes $F_{2}$ e $F_{3: 2}$, do cruzamento recíproco entre as cultivares Ripley e Spencer, em casa de vegetação, foi observado que a capacidade de resistir à manifestação dos sintomas foliares da doença, em 'Ripley', era condicionada por um único gene nuclear dominante, o qual foi denominado Rfs (Stephens et al., 1993a). Neste mesmo trabalho, os autores sugeriram que o modo de ação do gene Rfs pudesse ocorrer de duas maneiras: conferindo resistência à toxina produzida pelo fungo ou reduzindo a infecção radicular pelo patógeno durante os estágios iniciais da invasão. Posteriormente, em outros trabalhos, foi reafirmado que a resistência aos sintomas foliares da PVR em 'Ripley' é completa e condicionada por um único gene dominante (Heavner et al., 1996; Ringler \& Nickell, 1996). Este gene também foi denominado de Rfs1 (Meksem et al., 1999a e 1999b; Prabhu et al.,1999). Porém, herança completa monogênica só foi observada na cultivar Ripley. Assim, é possível que 'Ripley' tenha um mecanismo diferente de resistência.

Vários trabalhos demonstraram que a resistência a campo é parcial, poligênica e quantitativa (Abu-Thredeih et al., 1996; Chang et al., 1996; Hnetkovsky et al., 1996; Njiti et al., 1996, 1998a e 2002; Doubler et al., 1997; Kilo et al., 1997; Prabhu et al., 1999; Meksem et al., 1999a; lqbal et al., 2001), sendo que, inicialmente, foram encontrados quatro QRLs associados à resistência a PVR (Chang et al., 1996; Hnetkovsky et al., 1996). Destes, um QRL foi localizado no grupo de ligação $\mathrm{C}$ e outro no grupo $\mathrm{N}$, os quais explicaram $34 \%$ da variação fenotípica para a incidência da doença, sendo a herdabilidade desta característica estimada em 0,89 (Hnetkovsky et al., 1996). Outros dois QRLs foram localizados no grupo de ligação $G$, sendo que, juntamente com os dois anteriores, explicaram cerca de $65 \%$ da variação fenotípica total para incidência da doença, com herdabilidade estimada em 0,9 , e $50 \%$ da variabilidade na severidade da doença, sendo a herdabilidade desta estimada em 0,78 (Chang et al., 1996). As 
regiões genômicas C2 e G apresentaram efeito aditivo, porém, a região do grupo de ligação $G$ afetou claramente a severidade de infecção nas raízes, reduzindo a taxa de infecção das raízes e o desenvolvimento dos sintomas foliares com efeito muito maior do que a região $\mathrm{C} 2$, a qual pareceu apenas contribuir para a diminuição dos sintomas foliares (Njiti et al., 1998a). Segundo estes autores, os QRLs dos grupos de ligação G e C2 conferiram componentes separados de resistência a PVR e, portanto, eles foram considerados adequados para a realização de seleção visando o "piramidamento" de genes de resistência, ou seja, o "piramidamento" de QRLs.

Um QRL do grupo de ligação $G$ também foi identificado como sendo associado à resistência ao NCS (Chang et al., 1997; Doubler et al., 1997; Kilo et al., 1997; Meksem et al., 1999a e 1999b; Prabhu et al., 1999). Segundo Njiti et al. (1998a), esta região afeta claramente o índice de severidade da PVR nas raízes (herdabilidade de 0,7 ), podendo conferir resistência à infecção ou colonização pelo reconhecimento do patógeno, além de afetar também o desenvolvimento da doença na parte aérea (herdabilidade de 0,63). Pelos resultados de Prabhu et al. (1999), a existência de um "cluster" de genes de resistência a doenças no grupo de ligação G, incluindo os genes rhg1 (resistência à raça 3 do NCS) e Rfs1 (resistência a PVR), poderia ser a explicação porque a seleção para resistência a PVR, com base no marcador Satt038, teve alta correspondência com o fenótipo. Meksem et al. (1999a e 1999b) também fizeram referência a esta associação de genes de resistência (rhg1 e Rfs1) no grupo de ligação G.

Por outro lado, no cruzamento entre as cultivares Pyramid e Douglas, o QRL do grupo de ligação G explicou apenas a resistência ao NCS (raças 3 e 14), mas não a PVR, havendo pequena associação entre a resistência a estas duas doenças apenas no grupo de ligação $A_{2}, 0$ que indica diferença na herança da resistência entre estas cultivares e aquelas citadas anteriormente; claramente, o "cluster" de genes de resistência a PVR e NCS encontra-se em uma distância genética bem maior em 'Pyramid' x 'Douglas', cerca de 20 cM, contra apenas 2 cM em 'Forrest' x 'Essex' (Kilo et al., 1997). Também foi mostrado que o "cluster" de QRLs do grupo de ligação $G$, condicionando resistência a PVR e ao NCS raça 3, pode ser isolado (Doubler et al., 1997; Kilo et al., 1997; Meksem et al., 1999a e 1999b). Neste sentido, Meksem et al. (1999a) utilizaram NILs $F_{9: 5}$ derivadas de RILs do cruzamento entre 'Forrest' e 'Essex' e concluíram que um dos locos do grupo de ligação G, ligado ao marcador microssatélite Satt309, apresentou forte associação com a resistência a PVR (avaliada pelo índice de doença) e ao NCS, e o outro loco, ligado ao marcador RFLP Bng122D, apresentou apenas forte associação com a resistência a PVR (avaliada pelo índice de doença e pela severidade de infecção nas raízes). Em trabalho mais recente foram relatados seis QTLs responsáveis pela resistência a PVR, sendo cinco associados aos marcadores moleculares microssatélites Satt214, Satt309, Satt570 (todos do grupo de ligação G), Satt371 (grupo de ligação C2) e Satt354 (grupo de 
ligação I), e um ao marcador RAPD OE02 ${ }_{1000}$ (também do grupo de ligação G), os quais explicaram $91 \%$ da variação fenotípica para incidência foliar da PVR entre RILs do cruzamento 'Forrest' x 'Essex' (lqbal et al., 2001). Segundo os autores, pelos resultados obtidos foi demonstrado somente a presença de ação gênica aditiva, 0 que pode permitir 0 desenvolvimento de cultivares com resistência durável a PVR via "piramidamento de genes". Além disso, outra conclusão importante deste trabalho é que os QRLs associados aos marcadores Satt354 e Satt371 corresponderam aos alelos de resistência derivados do genitor suscetível ('Essex') e, juntamente, explicaram cerca de $40 \%$ da variação fenotípica na incidência da PVR. Njiti et al. (2002), trabalhando com marcadores moleculares RFLP, RAPD, microssatélites e AFLP, em outro cruzamento ('Pyramid' $x$ 'Douglas'), fazem referência a três QRLs, os quais explicaram cerca de $60 \%$ da variação fenotípica total da resistência a PVR. Destes, um foi localizado no grupo de ligação G (Satt163), próximo a Satt309 e Satt038, os quais foram fracamente ligados com a resistência a PVR, outro no grupo de ligação C2 (Satt307), e outro no grupo de ligação N (Satt080), próximo de Satt387, o qual também demonstrou forte ligação ao $Q R L$ da PVR. Este último então, corresponderia ao sétimo $Q R L$ da PVR e já havia sido relatado anteriormente por Hnetkovsky et al. (1996), como ligado a um marcador RAPD, embora lqbal et al. (2001) não detectaram sua associação com a resistência a PVR. De fato, segundo Triwitayakorn et al. (2002), existiriam pelo menos sete genes condicionando resistência a PVR, sendo que estes relataram o sequenciamento de três genes do grupo de ligação $G$ (Rfs1, Rfs2 e Rfs6), sendo os próximos a serem sequenciados os dos grupos de ligação C2 e I, respectivamente, Rfs4 e Rfs5.

Apesar da existência de interação genótipo x ambiente significativa (Rupe \& Gbur, 1995; Njiti et al., 1996 e 1997a), a herdabilidade da resistência a PVR foi alta quando avaliada em maior número de locais, variando de 0,68 a 0,83 para ambientes individuais e sendo de 0,75 na média de seis ambientes (Njiti et al., 1996). Em trabalho mais recente, Njiti et al. (2001) compararam resultados obtidos em cinco experimentos de campo e quatro experimentos conduzidos em casa de vegetação (com diferentes taxas de inóculo), obtendo herdabilidades de $0,46,0,66$ e 0,37 , respectivamente, para $10^{4}, 5 \times 10^{3}$ e $3,3 \times 10^{3}$ esporos $/ \mathrm{cm}^{3}$ de substrato, todas inferiores àquelas obtidas nos experimentos de campo; enquanto a correlação entre a severidade dos sintomas foliares em casa de vegetação e o índice de doença dos sintomas foliares a campo foi de $42 \%, 60 \%$ e $40 \%$, respectivamente, para as taxas alta, moderada e baixa de inóculo. Na média de quatro locais, Meksem et al. (1999a) encontraram herdabilidade de 0,7 para o índice da doença [(incidência/severidade)/9] na parte aérea e de 0,78 para a severidade de infecção ras raízes. A avaliação em um único ambiente não é indicada, pois podem ocorrer mudanças substanciais na ordem das cultivares de um local para outro, porém, a resistência de 'Forrest', por exemplo, é mais consistente entre os diversos ambientes do que a 
de 'Pyramid' (Njiti et al., 1996). Estes autores também concluíram que a ação gênica aditiva foi o contribuinte primário para as diferenças entre os genótipos para as médias de índice da doença e que, embora haja mais de um gene envolvido na resistência, provavelmente, poucos genes de efeito maior têm expressão em qualquer ambiente. Realmente, embora tenham sido avaliadas populações apenas dos cruzamentos 'Forrest' x 'Essex' (Abu-Thredeih et al., 1996; Chang et al., 1996 e 1997; Hnetkovsky et al., 1996; Doubler et al., 1997; Kilo et al., 1997; Torto et al., 1997; Njiti et al., 1998a; Meksem et al., 1999a; Iqbal et al., 2001); 'Hartwig' x 'Flyer', derivadas, respectivamente, de 'Forrest' e 'Essex' (Prabhu et al., 1999) e 'Pyramid' x 'Douglas' (Abu-Thredeih et al., 1996; Kilo et al., 1997; Njiti et al., 2002), até agora foram identificados apenas sete diferentes genes (QRLs) condicionando a resistência a PVR, conforme também comentado por Triwitayakorn et al. (2002).

Desta forma, dispondo-se de cultivares com diferentes fontes de resistência, é possível se proceder ao acúmulo de QRLs em linhagens resultantes do cruzamento entre estas, para conferir resistência durável a PVR. Isto é o que parece ter acontecido com a cultivar Forrest, pelo acúmulo não-intencional ce alelos de resistência a PVR ao longo de vários cruzamentos que antecederam o seu desenvolvimento. Segundo Chang et al. (1997), a maior parte da resistência a PVR de 'Forrest' é herdada de 'Dyer', que a herdou de 'Hill', a qual, por sua vez, parece ser o resultado da recombinação de vários genitores suscetíveis a PVR (CNS, S100, PI 36.846 e $\mathrm{PI}$ 6.396). Isto comprova a ocorrência de segregação transgressiva para resistência a PVR, pois os alelos de resistência podem vir tanto de genitores resistentes quanto de suscetíveis (Chang et al., 1996; Hnetkovsky et al., 1996; Njiti et al., 1998a e 2002; lqbal et al., 2001), sendo que fontes de tolerância a PVR, como as cultivares Essex e A5403, também são citadas (Njiti et al., 1997a).

Com relação à seleção de genótipos com maior nível de resistência, a princípio, esta deve ser efetuada em gerações mais avançadas, embora nada ainda tenha sido relatado se os genes de resistência são dominantes ou recessivos, parecendo ser mais adequado primeiro se fazer a seleção para rendimento de grãos e outras características agronômicas, e depois a avaliação da reação a PVR, em vários locais ou com inoculação artificial e, até mesmo, com a utilização dos marcadores moleculares citados.

\subsection{Reação de cultivares a PVR}

Até o presente, o uso de cultivares resistentes é a única estratégia viável para contornar os prejuízos causados pela PVR em áreas com elevada infestação do patógeno.

É importante salientar que ainda não foi encontrado nenhum genótipo imune ao ataque 
do patógeno causador da PVR, então, mesmo cultivares consideradas resistentes irão apresentar algum sintoma da doença, pelo menos nas raízes. Desta forma, a resistência a PVR foi definida como a demora ou ausência de expressão de sintomas foliares após um período de incubação, comparada com a rápida ou completa expressão dos sintomas foliares em genótipos padrões de suscetibilidade (Stephens et al., 1993b e 1993c). Por outro lado, a severidade dos sintomas radiculares da PVR pode não ser diferente entre os genótipos considerados resistentes e os suscetíveis pela avaliação dos sintomas foliares (Rupe et al., 1991; Gray \& Achenbach, 1996; Scherm \& Yang, 1996; Hartman et al., 1997).

Este fato, porém, é mais complexo, pois a ocorrência de altos níveis de infecção nas raízes, sem o desenvolvimento de sintomas foliares, sugere uma tolerância, a qual depende das condições ambientais, e pode ser confundida com resistência a PVR em avaliações pela incidência ou severidade dos sintomas foliares da doença (sintomas reflexo); certamente, a avaliação do germoplasma para freqüência e severidade de infecção nas raízes, a campo, poderá proporcionar a identificação de novos mecanismos de tolerância e resistência (Njiti et al., 1997a). Segundo estes mesmos autores, pela existência de resistência do tipo que diminui a taxa de infecção ("rate-reducing resistance"), a raiz principal tanto de genótipos suscetíveis quanto de resistentes é infectada pelo patógeno no início do desenvolvimento das plantas, mas a resistência é manifestada posteriormente, pela redução na freqüência e severidade de infecção na raiz principal e pela redução no índice de doença (calculado com base nos sintomas foliares padronizados para o estádio $\left.P_{6}\right)$ em cultivares resistentes comparadas com suscetíveis. No entanto, por não terem observado correlação da severidade dos sintomas foliares com a colonização da raiz principal e do caule, ou perdas no peso seco das raízes, Huang \& Hartman (1998) sugeriram que a infecção e colonização das raízes podem não ser tão importantes como a severidade dos sintomas foliares para se descrever a resistência de cultivares a PVR, além de considerar a sua avaliação difícil e demorada.

Assim, apesar das opiniões conflitantes, a amostragem de plantas para avaliação da freqüência e da severidade de infecção nas raízes, durante a fase reprodutiva, associada com a avaliação da incidência e severidade da doença na parte aérea, seria uma boa estratégia de seleção para o desenvolvimento de cultivares com resistência mais durável a PVR, apesar de bastante trabalhosa. Desta forma, a avaliação da resistência não seria feita com base apenas nos sintomas reflexo da doença, ou seja, nos sintomas foliares, os quais se manifestam em locais não colonizados pelo patógeno.

Parece que a resistência ao desenvolvimento de sintomas foliares da PVR pode ser devida, pelo menos em parte, à insensibilidade das plantas à toxina produzida pelo patógeno, podendo ser explorada a reação à toxina durante a discriminação de cultivares (Jin et al., 1996b). O mecanismo desta resistência, porém, é desconhecido, mas pode estar relacionado à 
redução no acúmulo da toxina ou na sua translocação, destoxificação ou, ainda, à combinação destes e de outros fatores (Hartman et al., 1997). Além disso, é necessário conhecer as condições que favorecem a produção da toxina e como fatores ambientais, fisiológicos e bioquímicos influenciam o movimento da toxina e o potencial de degradação das plantas (Huang \& Hartman, 1998).

As fitotoxinas produzidas pelo patógeno causador da PVR podem contribuir para a patogenicidade e são importantes no desenvolvimento dos sintomas, pois os resultados de trabalhos com o seu isolamento e inoculação em cultura de calos de soja e em explantes de plântulas cultivadas "in vitro" mostraram elevada correlação significativa com a expressão dos sintomas (Jin et al., 1996b; Huang \& Hartman, 1998). Ambos os métodos foram capazes de distinguir de forma consistente as cultivares resistentes das suscetíveis a PVR.

Os experimentos conduzidos com inoculação artificial em casa de vegetação comparam a reação dos genótipos de soja à toxina produzida pelo fungo, o que também deve ser o mecanismo de resistência primária no campo, mas devem haver outros aspectos da resistência que não foram associados com estes métodos, como a interação com a resistência à podridão radicular ou com a resistência ao NCS, fazendo com que a maioria das avaliações de cultivares nos EUA fosse feita no campo (Rupe, 1999).

No campo, diferenças no desenvolvimento da doença entre cultivares, provavelmente, sejam causadas por diferenças na taxa de evolução da doença, porque o início dos sintomas ocorre praticamente ao mesmo tempo para a maioria das cultivares dos grupos de maturação IV, VI, VII e VIII, inclusive em diferentes anos (Rupe et al., 1991). Entretanto, os autores constataram que a evolução da doença nas cultivares do grupo de maturação $V$ também foi influenciada pelo início do aparecimento dos sintomas, os quais ocorreram desde a fase vegetativa até o estádio $R_{6}$.

Por outro lado, quando a avaliação é eita utilizando-se inoculação artificial (com grãos de aveia ou de sorgo colonizados ou pelo método do palito de dente) em casa de vegetação, a manifestação dos sintomas é antecipada. Cerca de sete a dez dias após a inoculação com grãos de aveia já se pode verificar a presença de sintomas foliares da PVR (Lim, 1991; Stephens et al., 1993c). Assim, de maneira geral, a avaliação das cultivares pode ser feita duas a três semanas após a inoculação (Melgar \& Roy, 1994; Costa \& Yorinori, 1995a e 1995b; Hartman et al., 1997; Nelson et al., 1997; Huang \& Hartman, 1998; Leão et al., 1998).

No campo, a faixa de resposta das cultivares a PVR varia de nenhum sintoma ao completo desfolhamento e, apesar de alguns casos de frustração, devido ao não desenvolvimento de sintomas da doença, felizmente, a reação das cultivares é nitidamente consistente entre localidades com vários níveis de ocorrência da PVR (Rupe, 1999). No entanto, em algumas cultivares, a reação a PVR é bastante variável, o que torna necessária a 
avaliação em diversas localidades e durante mais de um ano; porém, diferenças de ano para ano, geralmente, envolvem mudanças na ordem das cultivares entre o topo e a faixa intermediária ou entre a faixa intermediária e a inferior (Rupe et al., 1991). Segundo estes autores, como nem sempre é possível avaliar os sintomas da doença na época mais adequada para cada cultivar em cada grupo de maturação, a ordem de classificação da reação das cultivares à doença, entre os estádios $R_{3}$ e $R_{6}$, pode ser utilizada para indicar a sua resposta a PVR, mesmo que em $R_{\beta}$ ainda não tenham sido observadas diferenças significativas quanto aos sintomas foliares entre as cultivares.

Entre os genótipos citados como resistentes nos Estados Unidos, as cultivares Forrest, Ripley e Jack, além da PI 520.733, eram utilizados como fontes de resistência a PVR naquele País (Njiti et al., 1997a).

Stephens et al. (1993b), utilizando microparcelas com solo proveniente de lavouras infestadas com o patógeno da PVR ou procedendo à inoculação artificial com grãos de aveia colonizados, identificaram como mais resistentes a linhagem D83-3349 e as cultivares Ripley, Hamilton, Bass e TN 4-86 entre os 12 genótipos avaliados.

Njiti et al. (1997a) conduziram experimentos a campo em dois locais, com dois grupos de materiais contrastantes (cinco genótipos suscetíveis e sete resistentes a PVR), e observaram que 0 grupo de genótipos resistentes a PVR apresentou freqüência significativamente menor de infecção nas raízes (porcentagem de segmentos de raízes infectados) do que o grupo dos materiais suscetíveis. Ainda segundo estes autores, o índice de doença, com base nos sintomas foliares, apresentou correlação significativa (variando de 0,29 a $0,61)$ com a freqüência e severidade de infecção nas raízes, podendo ser utilizado como uma maneira grosseira de predizer a resistência das plantas à infecção pelo patógeno. Com base nisso, os autores sugeriram que, na avaliação de genótipos visando desenvolver cultivares resistentes a PVR, deveria ser utilizada a combinação da taxa de invasão nas raízes, a avaliação dos sintomas foliares e marcadores moleculares, visto que também foi observada a ocorrência de elevados níveis de infecção nas raízes sem a manifestação de sintomas foliares.

Em estudo envolvendo mais de 800 genótipos e inoculação artificial com grãos de sorgo colonizados, entre 728 novas introduções provenientes da China, apenas cinco (PI 567.315, 567.374, 567.441C, 567.650B e 567.664) apresentaram severidade dos sintomas foliares da PVR significativamente inferior à testemunha resistente PI 520.733; entre os demais genótipos, os com a menor taxa de severidade dos sintomas foliares foram as cultivares Ripley, Forrest, Hartz 6686, BSR 101, Bass e Jack (Hartman et al., 1997).

No Brasil, inoculações artificiais e/ou observações de campo apresentaram as seguintes cultivares como mais tolerantes a PVR: BR-4, BR-6 (Nova Bragg), BR-9 (Savana), CAC-1, EMBRAPA-1 (IAS-5 RC), EMBRAPA-9 (Bays), EMGOPA-315 (Rio Vermelho), FT-5 
(Formosa), FT-7 (Tarobá), FT-9 (Inaê), FT-10 (Princesa), FT-14 (Piracema), FT-20 (Jaú), FTCometa, FT-Guaíra, FT-Jatobá, IAC-13, IAC-15, KI-S 601, KI-S 602 RCH, MG/BR-46 (Conquista), MT/BR-49 (Pioneira) e OCEPAR 4-Iguaçu (Embrapa, 2001). A cultivar IAC-4 também foi considerada altamente resistente em avaliações a campo (Yorinori et al., 1993).

Comparando a reação de cinco cultivares (FT-104, FT-Cristalina-RCH, FT-Estrela, EMGOPA 315 e CAC-1) pelo método do palito-de-dente, Leão et al. (1998) verificaram que CAC-1 e FT-104 foram as mais resistentes a PVR, enquanto que FT-Estrela e Cristalina foram as mais suscetíveis, e EMGOPA 315 apresentou reação intermediária.

Klingelfuss et al. (2001a), efetuando a inoculação pelo método do palito-de-dente, compararam cinco cultivares (Ripley, Canário, BRS Milena, Paiaguás e Conquista) e duas Pl's (520.733 e 567.374), todas tidas como resistente a PVR, com a cultivar suscetível FT-Estrela, e concluíram que as Pl's 520.733 e 567.374 e as cultivares Conquista e Canário foram as mais resistentes, sendo indicadas para utilização em cruzamentos visando resistência a PVR, enquanto a cultivar Estrela demonstrou ser um bom padrão de suscetibilidade.

Em três experimentos conduzidos a campo num mesmo local, envolvendo 91 genótipos, principalmente novas linhagens, Farias Neto et al. (2001) observaram que as cultivares EMGOPA 302, EMGOPA 316, Milena e Conquista se destacaram pela sua resistência, havendo também linhagens superiores que poderiam servir como fontes de resistência a PVR.

Com relação ao método de inoculação artificial para a avaliação dos genótipos, Njiti et al. (2001) compararam a utilização de três taxas de inóculo $\left(10^{4}, 5 \times 10^{3}\right.$ e $3,3 \times 10^{3}$ esporos $/ \mathrm{cm}^{3}$ de substrato) com resultados obtidos a campo, em cinco ambientes, e concluíram que a taxa moderada $\left(5 \times 10^{3}\right.$ esporos $/ \mathrm{cm}^{3}$ de substrato) foi a mais adequada para a seleção de genótipos resistentes, proporcionando uma taxa de erro (classificação como suscetíveis de genótipos classificados como resistentes a campo) de apenas 10\%, não mantendo nenhum genótipo classificado como suscetível a campo e conservando apenas $50 \%$ daqueles classificados como parcialmente resistentes a campo.

Utilizando dois métodos de inoculação (palito-de-dente e suspensão de micélio + esporos), em experimentos diferentes, Yorinori \& Nomura (1994) avaliaram 177 cultivares brasileiras, encontrando como resistentes as cultivares BR-27 (Cariri), FT-5 (Formosa), FT-15, FT-Jatobá e Paranagoiana e, como moderadamente resistentes, as cultivares BR-4, CAC-1, FT8 (Araucária), IAC-2, IAC-4, MT/BR-45 (Paiaguás), OCEPAR-4 (Iguaçu), OCEPAR-9 (SS-1) e UFV-9 (Sucupira).

Gásperi (2000) comparou os métodos do palito-de-dente e dos grãos de sorgo, avaliando os sintomas na parte aérea e no sistema radicular, respectivamente, e observou variação entre os dois métodos na reação das 30 cultivares testadas: BRS 137, BRS 138 e 
EMBRAPA 66 foram as mais resistentes no teste do palito, enquanto que no método dos grãos de sorgo, IAS 5 e BRS 137 foram as mais resistentes. O autor também concluiu que não houve correlação entre a expressão dos sintomas na parte aérea e nas raízes, demonstrando que os mecanismos de resistência envolvidos, possivelmente, sejam diferentes.

Além do método de inoculação, os resultados da avaliação a PVR também são dependentes das condições ambientais. Tanto as avaliações da reação das cultivares a PVR feitas no campo quanto em casa de vegetação estão sujeitas ao aparecimento de escapes. Além disso, a ocorrência de condições climáticas desfavoráveis, relacionadas com a disponibilidade de umidade no solo e com a temperatura, principalmente do solo, podem ser a causa de grandes frustrações durante as avaliações. De maneira geral, a expressão dos sintomas da PVR é favorecida pela ocorrência de temperaturas moderadas durante a estação de crescimento da soja mas, a campo, temperaturas diárias elevadas, de até 30 a 35ㄷ pareceram não causar efeito inibitório sobre o desenvolvimento da doença (Rupe, 1999). Entretanto, altas temperaturas na casa de vegetação podem impedir o desenvolvimento de sintomas foliares (Scherm \& Yang, 1996; Rupe, 1999). A temperatura do solo influencia de maneira diferente o desenvolvimento dos sintomas nas raízes e nas folhas pois, em casa de vegetação, enquanto os sintomas foram mais severos nas raízes quando a temperatura foi mais baixa $\left(15^{\circ} \mathrm{C}\right)$, havendo efeito linear decrescente com o acréscimo da temperatura do solo, a severidade dos sintomas foliares foi maior com temperaturas intermediárias (22 a 24ํㅡ), decrescendo rapidamente com o aumento da temperatura (Scherm \& Yang, 1996). Neste mesmo trabalho, também se observou que a severidade dos sintomas foliares decresceu rapidamente com a diminuição da umidade do solo de $-0,003 \mathrm{MPa}$ para $-0,01 \mathrm{Mpa}(-2,2$ a $-7,5$ $\mathrm{cm}$ de $\mathrm{Hg}$ ), estando negativamente correlacionada com o número de dias que o potencial matricial de água no solo esteve menor do que -0,01 MPa. Melgar et al. (1995) também observaram associação entre o grau de severidade da PVR e o teor de umidade do solo, sugerindo que a redução no nível de $\mathrm{O}_{2}$ do solo prejudicaria o desempenho das funções das raízes e poderia explicar, pelo menos em parte, a maior predisposição das plantas de soja a PVR em solos com maior teor de umidade.

Além da temperatura e da umidade do solo, outros fatores podem influenciar a reação dos genótipos a PVR, como a presença do nematóide de cisto da soja (NCS) e os nematóides formadores de galhas, assim como outras doenças do sistema radicular. 


\subsection{ANÁLISE DIALÉLICA DE JINKS-HAYMAN}

Em programas de melhoramento envolvendo hibridações, dois itens são de importância fundamental para a obtenção de maior eficiência: o primeiro é a escolha adequada dos genitores e, o segundo, é o método de condução das populações segregantes.

Desta forma, torna-se necessário o conhecimento da concentração de alelos favoráveis em cada genitor, assim como das populações segregantes mais promissoras, além da natureza dos sistemas gênicos que controlam as características de interesse e do grau de influência dos efeitos ambientais sobre a expressão destas características. Tendo-se estas informações, com certeza, os ganhos genéticos esperados serão maiores e obtidos mais rapidamente do que aqueles atingidos somente com a capacidade de observação do melhorista.

Dentre as metodologias que permitem a análise genética, sem dúvidas, o estudo de cruzamentos dialélicos é a que fornece mais subsídios para o melhorista conduzir seu programa de melhoramento envolvendo hibridações artificiais. Neste sentido, destacam-se as metodologias de análise dialélica propostas por Jinks \& Hayman (1953), por Griffing (1956) e por Gardner \& Eberhart (1966). Nesta última, são avaliados os efeitos de variedades e da heterose varietal, a qual é separada nos seus diversos componentes (Gardner \& Eberhart, 1966), enquanto na metodologia de Griffing (1956) são estimados os efeitos da capacidade geral (CGC) e específica (CEC) de combinação. Já na metodologia de Jinks e Hayman (Jinks \& Hayman, 1953; Hayman, 1954a, 1954b, 1958 e 1960; Jinks, 1954 e 1956) são obtidas estimativas que quantificam as variações gênicas aditivas e dominantes, o grau médio de dominância, a distribuição dos alelos nos genitores e a herdabilidade nos sentidos amplo e restrito, além de se obter um indicativo dos limites teóricos de seleção. Apesar desta última ser mais conhecida apenas como metodologia de Hayman, a denominação mais adequada seria "Método de Jinks e Hayman", pois ambos foram autores do trabalho em que esta metodologia foi proposta pela primeira vez, segundo o artigo de Jinks \& Hayman (1953). Porém, após 1953, cada autor detalhou a proposta inicial e publicou seus trabalhos individualmente, tornando-se mais conhecidos os artigos de Hayman. Assim, de agora em diante, passará a se denominar este método como de Jinks-Hayman, da mesma forma que Ferreira (1985 e 1988) e Ramalho et al. (1993). Provavelmente, a denominação de "Método ce Hayman" se deva ao fato de que a maioria dos autores utilizam como referência o trabalho de Hayman (1954a), o qual é mais completo que o de Jinks \& Hayman (1953) e mais claro e detalhado que o de Jinks (1954).

Apesar das críticas de alguns autores (por exemplo: Kempthorne, 1956; Arunachalam, 1976; Sokol \& Baker, 1977; Baker, 1978) sobre a validade das conclusões das análises dialélicas, esta metodologia é bastante utilizada e, com certeza, o método proposto por Griffing (1956) é o de uso mais comum. Segundo Ramalho et al. (1993), no método de Jinks-Hayman 
estimam-se principalmente variâncias, as quais seriam menos úteis para os melhoristas de autógamas do que os componentes de média estimados pelos métodos de Griffing e de Gardner \& Eberhart. Por outro lado, o método de Jinks-Hayman foi considerado bastante poderoso para a análise de ação gênica, pelo grau de detalhamento das análises, o que o torna muito mais informativo que os demais (Toledo \& Kiihl, 1982; Hill et al., 2001). De forma resumida, enquanto o método de Griffing fornece estimativas de apenas dois componentes genéticos (CGC e CEC), o método de Jinks-Hayman fornece a estimativa de quatro componentes da variação genética $(\mathrm{D}=$ efeitos gênicos aditivos; $\mathrm{F}=$ covariância entre efeitos gênicos aditivos e dominantes, indicando a frequência relativa dos alelos dominantes e recessivos nos genitores; $H_{1}=$ efeitos gênicos dominantes; $H_{2}=$ efeito gênico dominante corrigido para a distribuição dos genes, indicando a simetria dos efeitos positivos e negativos dos genes), além de fornecer a distribuição relativa dos alelos nos genitores.

Embora menos difundido que o método de Griffing, dezenas de autores têm utilizado a metodologia de Jinks-Hayman. Entre estes citam-se os seguintes: Toledo \& Kiihl (1982), Freire Filho (1988), Bonato (1989), Martins Filho (1999) e Lopes (2001), todos trabalhando com soja; Tandon et al. (1970) e Barriga B. (1979) com trigo; Jones et al. (1972) com fumo; Oliveira et al. (2001) com pimentão; Santos (1984) e McPhee et al. (2002) com feijoeiro; Xu \& Shen (1991), Chaubey et al. (1994) e Hill et al. (2001) com arroz; e Amaral Júnior et al. (1999) com tomateiro.

Provavelmente, o maior entrave para a utilização mais ampla do método de JinksHayman seja o atendimento de todas as restrições impostas ao modelo genético em estudo. Segundo Hayman (1954a) seis hipóteses (na proposta original de Jinks \& Hayman, 1953, eram apenas quatro) devem ser atendidas para que o modelo aditivo-dominante proposto possa ser utilizado; caso contrário, terá que se utilizar um modelo genético mais complexo, com a inclusão de outros parâmetros. $O$ autor considera as seguintes hipóteses ou restrições para a utilização do método:

a) Segregação diplóide;

b) Ausência de diferenças entre cruzamentos recíprocos;

c) Ação independente de genes não-alélicos;

d) Ausência de alelismo múltiplo;

e) Genitores homozigóticos;

f) Genes independentemente distribuídos entre os genitores.

Pela importância destas restrições, são pertinentes os seguintes comentários a cada uma delas, mais especificamente quando se estuda a resistência a PVR em soja:

a) A segregação diplóide é o normal da espécie;

b) A maioria dos caracteres de importância agronômica em soja não apresenta efeito recíproco entre cruzamentos (efeito materno), com exceção de alguns caracteres associados æ̀ 
sementes (por exemplo, os teores de óleo e de proteína). Como se trata de resistência a PVR, então excluí-se a presença de efeito materno;

c) A presença de epistasia é testada pela própria metodologia, sendo que esta rão pode ser utilizada caso se detectem efeitos epistáticos (coeficiente angular da equação de regressão de $W_{i}$ em função de $V_{i}$ diferente de 1,0); no trabalho com marcadores moleculares de lqbal et al. (2001), envolvendo seis QRLs que condicionam resistência a PVR, não foi detectada a presença de efeitos epistáticos entre estes locos, indicando o atendimento desta restrição;

d) Com o uso de marcadores moleculares codominantes (multialélicos), como os microssatélites, ligados aos QRLs cujos efeitos estão sendo estudados, é possível certificar-se da presença ou não de multialelismo. Neste sentido, nos trabalhos de Mudge et al. (1997) e Bell-Johnson et al. (1998), envolvendo o uso de marcadores moleculares microssatélites, foi citada a presença de multialelismo em locos condicionando a resistência a PVR no grupo de ligação G. Isto comprova a dificuldade de se atender a esta restrição. Entretanto, o próprio Hayman (1954a) comenta que, na ausência de segregação, ou seja, trabalhando-se com a geração $F_{1}$, a presença de multialelismo é equivalente a "bialelismo poligênico exibindo interação gênica e distribuição correlacionada" e que qualquer grupo de $2^{p}$ alelos múltiplos equivale, de maneira geral, a "p" pares de alelos; porém, podem existir sistemas mais complexos $\left(2^{\mathrm{p}}\right)$ e com efeitos extremamente complicados. Por outro lado, Johnson, citado por Toledo \& Kiihl (1982), comenta que é possível restringir o sistema gênico para apenas dois alelos por loco sem prejuízo nas análises;

e) Por se tratar de espécie autógama, esta restrição é plenamente atendida quando são utilizadas linhagens homozigóticas ou cultivares;

f) Quando são utilizados genitores divergentes, com certeza, esta restrição é razoavelmente atendida, apesar de que a base genética da soja no Brasil seja considerada estreita. Hayman (1954a) fez comentários sobre o que pode acontecer com os resultados quando a distribuição dos genes nos genitores é correlacionada, como por exemplo: se as estimativas de $\mathrm{F}=0$ e $\mathrm{H}_{1}=\mathrm{H}_{2}$ a medida da frequência gênica não é afetada; dependendo do caso, o grau médio de dominância pode ser superestimado, entre outras considerações. Segundo Nassar (1965), numa simulação envolvendo 180 dialelos de diferentes tamanhos (6x6,

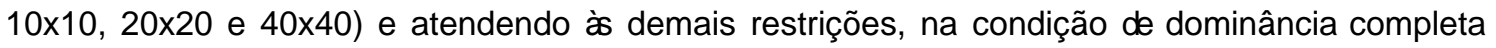
a distribuição correlacionada dos genes entre os genitores conduziu às seguintes conclusões na análise gráfica: 1) O coeficiente angular da regressão (b) tende a assumir valores inferiores a $1,0 ; 2) \mathrm{O}$ intercepto tende a assumir valores menores que zero (negativos), conduzindo a um falso efeito de sobredominância (pseudo-sobredominância); 3) A intensidade destes desvios (itens 1 e 2) foi maior no menor dialelo, diminuindo com o aumento do número de genitores do dialelo. $O$ autor sugeriu que os desvios relacionados com o coeficiente da regressão e 0 
intercepto são mais intensos em presença de sobredominância, do que na condição de dominância parcial, assim como os desvios são menores quando a dominância não for unidirecional. Estas observações ajudam a comprovar a sensibilidade do teste de suficiência do modelo em detectar o não-atendimento das restrições impostas para a sua utilização. Ferreira (1988) também avaliou os efeitos da distribuição não-independente dos genes nos genitores, formulando novas estimativas para os componentes genéticos $\mathrm{D}, \mathrm{H}_{1}, \mathrm{H}_{2}$ e $F$ do modelo de Jinks-Hayman com robustez suficiente para suportar desvios nesta restrição. Segundo o autor, a vantagem relativa do uso das novas estimativas diminuiu à medida que aumentou o tamanho do dialelo, o que confirmou a informação de Nassar (1965) de que a intensidade das distorções foi maior em dialelos menores.

$O$ atendimento de todas estas restrições é testado de maneira conjunta pelo teste de suficiência do modelo aditivo-dominante. Como consequência do ajuste ao modelo e atendimento das restrições impostas, os valores de $\mathrm{W}_{\mathrm{i}}-\mathrm{V}_{\mathrm{i}}$ (covariâncias menos variâncias dentro da i-ésima linha ou coluna) são constantes, independendo da linha (ou coluna) considerada (Hayman, 1954a). No entanto, o autor comenta que a homogeneidade dos valores de $W-V_{i}$ também pode ser consequência de que a falha em uma hipótese é compensada pela falha em outra. Os testes para verificar a suficiência do modelo aditivo-dominante são os seguintes (Hayman, 1954a):

1) Quando se dispõe de repetições do experimento (tabela dialélica): procede-se a uma análise de variância, considerando-se como fontes de variação as repetições da tabela dialélica e as linhas (ou colunas) dentro de cada tabela. Se o efeito de linhas é significativo, isto indica que há falhas nas pressuposições, porém, a principal falha estatística deste teste é que os " $\mathrm{n}$ " valores de $W_{i}-V_{i}$ são correlacionados;

2) Quando se dispõe de apenas uma tabela dialélica: neste caso, o teste baseia-se no gráfico da análise de regressão de $W$ em função de $V_{i}$. Para fornecer um teste com mesmo peso para $\mathrm{W}_{\mathrm{i}}$ e $\mathrm{Vi}$, faz-se uma rotação de $45^{\circ}$ no eixo do gráfico, de tal maneira que as coordenadas dos pontos tornam-se proporcionais a $W_{i}+V_{i}$ e $W_{i}-V_{i}$. Após isto, testa-se a significância do coeficiente de regressão no novo eixo $\left(\mathrm{H}_{0}\right.$ : $\left.b^{\prime}=0\right)$ por um teste " $\mathrm{t}$ " com " $\mathrm{n}-2$ " graus de liberdade. Se o resultado der significativo, há falha nas hipóteses. A limitação deste teste é que ele detecta somente as variações nos valores de $W_{i}-V_{i}$ que estão correlacionadas com os efeitos de dominância dos genitores. No entanto, a variação que aumenta apenas a dispersão dos pontos em torno da linha de regressão, sem alterar a sua inclinação, é detectada no teste anterior.

Outra maneira de testar o coeficiente de regressão (b), quando se dispõe de apenas uma tabela dialélica, é verificar se ele é igual a 1,0 ( $\left.\mathrm{H}_{0}: \mathrm{b}=1,0\right)$ utilizando-se o teste " $\mathrm{t}$ " com " $\mathrm{n}-2$ " graus de liberdade (Cruz \& Regazzi, 1997). Se o resultado do teste for significativo há falha nas 
hipóteses.

Quando se dispõe de repetições da tabela dialélica também é possível se proceder à análise de variância dos valores de $\mathrm{W}_{1}+\mathrm{V}_{\mathrm{i}}$, de maneira semelhante àquela para os valores de $W_{i}-V_{i}$. Se o efeito de $W_{i}+V_{i}$ for significativo, há evidências de que há efeito de dominância (Mather \& Jinks, 1984). Procedendo-se a uma análise de variância mais detalhada, é possível testar a significância dos componentes genéticos aditivos (fonte de variação "a") e de dominância (fonte de variação "b"), assim como da decomposição da variância de dominância (fonte de variação "b") (Hayman, 1954b; Jones, 1965; Mather \& Jinks, 1982; Santos, 1984; Ramalho et al., 1993), utilizando-se como resíduo o erro experimental calculado com base na média das repetições da tabela dialélica (Ramalho et al., 1993). Com a decomposição da variância de dominância (fonte de variação "b") testam-se os seguintes efeitos: "b1" - diferença entre a média dos genitores e a média dos cruzamentos; " $\mathrm{b}_{2}$ " - proporção de alelos dominantes nos genitores; " $\mathrm{b}_{3}$ " - desvios de dominância específicos para cada cruzamento, ou seja, a presença de capacidade específica de combinação. Esta análise também permite que se comparem os resultados do método de Hayman (1954b) com os métodos de Griffing (1956) e de Gardner \& Eberhart (1966), pois as fontes de variação são idênticas para as três metodologias, havendo diferenças apenas nas informações que cada uma fornece; devendo-se lembrar que o método de Griffing (1956) também difere dos demais por não decompor a CEC (Ramalho et al., 1993). Assim, segundo estes autores, as fontes de variação "a", "b", "b 1 ", "b2" e " $b_{3}$ " correspondem, respectivamente, aos efeitos de cultivares, heterose, heterose média de cruzamentos, heterose de cultivares e heterose específica (CEC) do método de Gardner \& Eberhart (1966). Por outro lado, as fontes de variação "a" e "b" correspondem, respectivamente, a CGC e CEC do método 2 de Griffing (1956) e, a fonte de variação "b3", a CEC do método 4 de Griffing (1956), mas esta última precisa de adequação do número de graus de liberdade para ser testada corretamente.

A análise dialélica de Jinks-Hayman pode ser aplicada tanto para a geração $F_{1}$ como para $F_{2}$, assim como para tabelas dialélicas completas e para meias tabelas dialélicas (sem os recíprocos), desde que se façam as devidas adaptações. Pela ausência de efeito de cruzamentos recíprocos para a maioria dos caracteres de interesse agronômico, conforme já comentado, as meias tabelas dialélicas são as mais utilizadas no caso da soja. Com relação à utilização da geração $F_{2}$, há críticas no sentido de que a segregação observada em diferentes populações $F_{2}$ de um mesmo cruzamento não seria a mesma, além de exigir a avaliação de um grande número de indivíduos (Arunachalam, 1976). Porém, para as espécies autógamas em que há dificuldade para se produzir um grande número de sementes $F_{1}$, como é o caso da soja, é mais prático se utilizar a geração $F_{2}$, especialmente quando se pretende avaliar caracteres que sofrem elevada influência do ambiente, exigindo a avaliação de dezenas de plantas e, até 
mesmo, em mais de um ambiente, para a obtenção de resultados mais seguros. Além disso, a avaliação de plantas individuais $F_{2}$ e dos genitores também possibilita que se estime a variância genética dentro de cada cruzamento, informação útil para a discriminação de cruzamentos mais promissores para a seleção posterior, nas gerações mais avançadas de autofecundação. 


\section{MATERIAL E MÉTODOS}

\subsection{Estudo da herança da resistência da soja a PVR}

\subsubsection{Obtenção das sementes $F_{1}$ e $F_{2}$}

Na safra 1999/2000 foram realizados todos os cruzamentos biparentais possíveis, com exceção dos recíprocos, entre seis genitores, sendo quatro com reação de resistência a PVR: MG/BR-46 (Conquista), IAC-4, Forrest e Ripley; e dois com reação de suscetibilidade: FT-Cristalina e FT-Estrela; num total de 15 cruzamentos $\{[n(n-1)] / 2\}$, os quais foram efetuados em telado tropical, no Setor de Genética Aplicada às Espécies Autógamas do Departamento de Genética da ESALQ/USP. Posteriormente, a cultivar Ripley e seus cruzamentos foram excluídos dos trabalhos, por esta ter se manifestado altamente suscetível a PVR em teste de inoculação efetuado. Após este mesmo teste, a cultivar IAC-4 passou a ser considerada moderadamente resistente.

As cultivares utilizadas foram originadas dos seguintes cruzamentos:

- MG/BR-46 (Conquista): Lo 76-4484 x Numbaíra;

- IAC-4: IAC-2 x Hardee;

- Forrest: Dyer x Bragg;

- Ripley: Hodgson x V68-1034;

- FT-Cristalina: seleção em UFV-1, mas pode ser um cruzamento natural de UFV-1 x Davis (Spehar, 1994);

- FT-Estrela: M-2 x FT-1.

Com exceção da cultivar Davis, ancestral de 'Conquista' e possível genitor de 'Cristalina', e que a linhagem M-2 é irmã de 'Cristalina', não se observou a existência de nenhum outro ancestral comum entre estas cultivares .

Para a realização dos cruzamentos, o grupo dos genitores foi semeado em quinze épocas, a partir de 04/10/1999, com intervalos de uma semana, visando-se obter maior coincidência do florescimento entre os genótipos e, também, aumentar o período com flores disponíveis para serem cruzadas. Em cada época de semeadura foi semeado um vaso de 
cerâmica (com capacidade para cerca de quatro litros de solo) para cada cultivar, colocando-se dez sementes por vaso, sendo deixadas apenas três plântulas em cada um após o desbaste. A irrigação foi efetuada manualmente, diariamente ou quando necessário, e o tutoramento das plantas foi efetuado com uma estaca de bambu (com cerca de 2,5 m de comprimento) colocada em cada vaso. Quando necessário, fez-se o controle de insetos (mosca branca, tripes e ácaros) e de oídio, com inseticidas apropriados.

Inicialmente, os cruzamentos foram realizados no final da manhã e início da tarde e, posteriormente, concentraram-se no final da tarde, pela maior taxa de pegamento verificada neste horário. As flores do genitor feminino utilizadas para os cruzamentos foram aquelas ainda no estádio de botão, ou seja, as quais abririam dentro de um ou dois dias. Estas tiveram suas sépalas e pétalas retiradas com o auxílio de uma pinça, de modo a expor o estigma, mas não foram emasculadas completamente, pois ainda não estavam maduras. Assim, apenas parte das anteras foi retirada, para não causar danos aos órgãos femininos. As flores fornecedoras de pólen (genitor masculino) foram aquelas que se abriram no dia do cruzamento, sendo extraído o seu conjunto de estigma e anteras, o qual foi friccionado levemente sobre o estigma exposto do genitor feminino, ou simplesmente deixado sobre este, para se proceder à polinização. Cultivares com flores brancas (marcador fenotípico recessivo) foram sempre utilizadas como genitor feminino, de forma a facilitar a separação dos híbridos $F_{1}$ de indivíduos provenientes de autofecundação.

Após a polinização foi efetuada a identificação do cruzamento com uma etiqueta de relojoeiro contendo o número do genitor masculino, o número de flores polinizadas por inflorescência, a data do cruzamento e as iniciais da pessoa que o realizou (se necessário). Posteriormente, com o desenvolvimento das vagens, procedeu-se a verificações nas inflorescências utilizadas nos cruzamentos, eliminando-se vagens não oriundas de cruzamentos e também a etiqueta de identificação de inflorescências nas quais nenhum cruzamento pegou, de forma a reduzir o risco de colher vagens provenientes de autofecundação e facilitar a colheita das vagens híbridas, além de proporcionar melhores condições para o desenvolvimento destas.

As vagens oriundas dos cruzamentos, à medida que se aproximaram da maturação, foram colhidas individualmente (confirmando-se a presença de "cicatriz" na região das sépalas) com as respectivas etiquetas, colocadas em pequenos sacos de papel identificados e deixadas para completar a secagem à sombra, após o que foram armazenadas em câmara fria $\left( \pm 15^{\circ} \mathrm{C}\right)$ e seca (UR $\pm 45 \%)$.

Para a obtenção das sementes $F_{2}$, na safra de 2000/2001, em telado tropical, cada vagem $F_{1}$ foi semeada individualmente, em vasos de cerâmica com cerca de quatro litros de solo, colocando-se cada semente em uma cova, num total de dez vasos por cruzamento e por 
genitor. A semeadura foi efetuada em 17/11/2000. Também se fez a semeadura de parte das sementes $F_{1}$ no campo, em 22/11/2000, na Estação Experimental de Anhembi, pertencente ao Departamento de Genética da ESALQ/USP, semeando-se três covas, espaçadas de 0,8 x $1,0 \mathrm{~m}$, para cada cruzamento ou genitor. Cada cova recebeu as sementes de apenas uma vagem.

Como nos cruzamentos não foi efetuada a emasculação completa, tornou-se necessária a eliminação de plantas provenientes de autofecundação, pela observação, quando possível, de caracteres morfológicos marcadores, como cor do hipocótilo, cor da flor, cor da pubescência e cor da vagem. As plantas nas quais o gene marcador do cruzamento não se expressou foram descartadas. Para os cruzamentos envolvendo as cultivares norte-americanas Forrest e Ripley, o ciclo e a altura da planta também foram utilizados como caracteres marcadores.

As plantas $F_{1}$ foram colhidas individualmente, debulhadas manualmente e as sementes $F_{2}$ obtidas foram utilizadas para a semeadura em vasos, para a avaliação da reação a PVR.

\subsubsection{Obtenção e manutenção do isolado do patógeno}

O isolado de F. solani f.sp. glycines utilizado foi obtido junto ao Dr. José Tadashi Yorinori, pesquisador da Embrapa Soja, Londrina-PR, sendo denominado SDS-5, o qual foi considerado como o mais patogênico entre todos os isolados coletados no Brasil pela equipe da Embrapa.

O isolado foi mantido em tubos de ensaio $(20 \times 200 \mathrm{~mm})$ ou placas de Petri, deixados sobre a bancada do laboratório, a temperatura ambiente, ou em sala climatizada $\left(22 \pm 2^{\circ} \mathrm{C}\right)$, por transferências sucessivas em meio BDA $(250 \mathrm{~g} / \mathrm{L}$ de batata : $12 \mathrm{~g} / \mathrm{L}$ de dextrosol : $18 \mathrm{~g} / \mathrm{L}$ de ágar comum ou ágar bacteriológico).

\subsubsection{Testes de inoculação}

No primeiro teste de inoculação artificial utilizando-se grãos de sorgo colonizados com o patógeno causador da PVR, este foi obtido a partir de plantas com sintomas foliares e radiculares típicos da doença, coletadas no município de Uberaba-MG, em março de 2000. A semeadura foi efetuada em 29/04/2000, em casa de vegetação de vidro, com controle automático de temperatura, no Departamento de Genética da ESALQ/USP. Foram utilizadas duas cultivares contrastantes quanto à resistência a PVR (Forrest e Cristalina), dois tipos de 
recipientes (vasos de cerâmica, com capacidade para três litros de solo esterilizado em autoclave, e sacos pláticos pretos, com cerca de $20 \mathrm{~cm}$ de diâmetro e $20 \mathrm{~cm}$ de altura, contendo cinco litros de solo esterilizado), duas quantidades de grãos de sorgo colonizados com o patógeno (dois e quatro grãos por cova) e duas repetições.

No segundo teste de inoculação utilizou-se o isolado SDS-5, obtido junto a Embrapa Soja, Londrina-PR, o qual também foi utilizado em todos os experimentos posteriores. A semeadura foi realizada em 19/06/2000, na mesma casa de vegetação. Foram utilizados vasos de cerâmica com capacidade para três litros de solo (esterilizado em autoclave), duas quantidades de grãos de sorgo (três e seis grãos por cova) e oito cultivares: Conquista, Cristalina, Estrela, Forrest, IAC-4, Ripley, IAC-8 e OCEPAR-9 (SS-1). As seis primeiras fizeram parte do dialelo $6 \times 6$ e as duas últimas foram utilizadas em outros trabalhos.

Um terceiro teste de inoculação também foi instalado na mesma casa de vegetação, com semeadura em 31/08/2000. Foram utilizados vasos de cerâmica com capacidade para três litros de solo (esterilizado em autoclave). Utilizou-se o delineamento em blocos ao acaso, com quatro repetições, sendo que os tratamentos consistiram de oito cultivares: Conquista, Cristalina, Estrela, Forrest, IAC-4, Ripley, IAC-8 e OCEPAR-9 (SS-1). Para a inoculação, em duas covas de cada vaso foi colocado $0,5 \mathrm{~mL}$ de inóculo, o qual conteve cerca de $1,5 \times 10^{5}$ fragmentos de micélio/mL, obtido a partir da trituração de grãos de sorgo colonizados com o patógeno, o que foi efetuado em liquidificador (um minuto em velocidade 1), após adicionar-se água destilada autoclavada até cerca de $1 \mathrm{~cm}$ acima do nível dos grãos. Em outras duas covas de cada vaso, na extremidade oposta das anteriores, foram colocados dois grãos de sorgo colonizados com o patógeno. Na última cova, localizada no centro de cada vaso, não foi colocado nenhum inóculo. Em duas repetições, a quantidade de ambas as formas de inóculo foi duplicada.

Um quarto teste de inoculação foi instalado em telado (sem controle de temperatura). A semeadura foi efetuada em 08/07/2002. Foram utilizados vasos de cerâmica com capacidade para três litros de solo, o qual não foi esterilizado. Utilizou-se um experimento no esquema fatorial, em blocos ao acaso, com quatro repetições. Os tratamentos consistiram da combinação de nove cultivares: Conquista, Cristalina, Estrela, Forrest, IAC-4, IAC-8, IAC-8-2, OCEPAR-9 (SS-1) e Essex, e dois tipos de grãos colonizados com o patógeno: grãos de sorgo (cinco grãos por cova) e grãos de soja (um grão por cova, cuja colonização com o patógeno foi efetuada de maneira semelhante aos grãos de sorgo, com a diferença de que o período de incubação foi de apenas sete dias). O inóculo foi colocado no fundo das covas, a $5 \mathrm{~cm}$ de profundidade e, diretamente sobre este, foram colocadas duas sementes de soja por cova. 


\subsubsection{Preparo do inóculo e inoculação das plantas da geração $F_{2}$}

Foram conduzidos três experimentos com a geração $F_{2}$, sendo um em telado do tipo tropical (sem controle de temperatura) e dois em casa de vegetação de plástico, sendo esta com controle automático de temperatura e umidade relativa do ar e com sombrite externo ( tipo "aluminet", movimentado manualmente por meio de corrente).

Tanto nas avaliações em telado quanto em casa de vegetação, foram utilizados vasos de cerâmica, com capacidade para três litros de solo (não esterilizado). O solo utilizado no experimento do telado foi proveniente de composto orgânico e o utilizado nos experimentos da casa de vegetação de uma área virgem (não cultivada).

Cada vaso recebeu dez sementes de soja, dispostas em cinco covas, sendo mantida apenas uma planta por cova após o desbaste, realizado logo após a emergência. Este procedimento também foi o mesmo para todos os testes de inoculação relatados anteriormente. Em todos os experimentos, os vasos (e também sacos plásticos do teste de inoculação) utilizados apresentavam um orifício na parte inferior, para a drenagem do excesso de água, assim como, cada vaso (ou saco plástico) foi colocado sobre um prato de plástico, a fim de evitar a disseminação do patógeno e também de auxiliar na manutenção da umidade no seu interior.

Para a inoculação das plantas foi utilizado o método dos grãos de sorgo (do tipo vermelho) colonizados com o patógeno, cujo procedimento foi semelhante ao proposto originalmente por Lim (1991), o qual utilizou grãos de aveia, seguindo-se as modificações efetuadas por Hartman et al. (1997) e Balardin \& Rubin (1999), os quais utilizaram grãos de sorgo.

O inóculo foi produzido utilizando-se frascos Erlenmeyer de $250 \mathrm{~mL}$, em cada qual foram colocados cerca de $100 \mathrm{~cm}^{3}$ de grãos de sorgo vermelho e adicionado água destilada em volume suficiente para promover a sua embebição durante uma noite (cerca de 12 horas). No dia seguinte, a água restante foi eliminada e os frascos contendo as sementes embebidas foram autoclavados duas vezes, durante 20 minutos a $120^{\circ} \mathrm{C}$, com intervalo de 24 horas. Após o resfriamento, cada frasco recebeu oito discos, com $5 \mathrm{~mm}$ de diâmetro, de meio BDA com o fungo em desenvolvimento por cerca de 15 dias, sendo então incubados em sala climatizada, durante cerca de três semanas, à temperatura de $22 \pm 2^{\circ} \mathrm{C}$ e com fotoperíodo de 12 horas. Para o preparo do inóculo do segundo experimento da casa de vegetação (2002), foram utilizados Erlenmeyers de $500 \mathrm{~mL}$ e cerca de $200 \mathrm{~cm}^{3}$ de grãos de sorgo autoclavados em cada um, cuja colonização com o patógeno foi efetuada pela adição de 15 discos de meio BDA com o fungo e, em seguida, adicionaram-se $10 \mathrm{~mL}$ de água destilada estéril para promover um melhor espalhamento dos esporos e micélio e o umedecimento dos grãos de sorgo. Para promover o 
crescimento uniforme do micélio do fungo em torno dos grãos de sorgo e para manter os grãos soltos, os frascos foram agitados periodicamente, conforme necessário (diariamente ou a cada dois a três dias).

Para a inoculação, no momento da semeadura foram colocados no solo, no fundo de cada cova (a $\pm 5 \mathrm{~cm}$ de profundidade), três grãos de sorgo colonizados com o patógeno. Estes foram cobertos com uma camada de solo de cerca de $2 \mathrm{~cm}$ de altura e, em seguida, foram colocadas as sementes de soja, as quais também foram cobertas com solo. Desta forma, os grãos de sorgo ficaram cerca de $2 \mathrm{~cm}$ abaixo das sementes de soja, evitando-se o contato direto destas com o inóculo. No segundo experimento realizado na casa de vegetação (2002) utilizaram-se covas com $4 \mathrm{~cm}$ de profundidade e as sementes de soja foram colocadas em contato direto com os três grãos de sorgo colonizados com o patógeno; aos 13 dias após a emergência foi efetuada outra inoculação, após o quase encharcamento do solo, pressionandose dois grãos de sorgo colonizados (a cerca de $1 \mathrm{~cm}$ de profundidade), com o auxílio de um bastão de vidro, junto àregião do colo de cada planta e em posição oposta.

\subsubsection{Instalação e condução dos experimentos de inoculação com a geração $F_{2}$}

Foram conduzidos três experimentos com a geração $F_{2}$, no Departamento de Genética da ESALQ/USP, nos seguintes locais de instalação e épocas de semeadura:

- TE-JUL01: instalado em telado, em 09 e 10/07/2001;

- CV-SET01: instalado em casa de vegetação, em 27 e 28/09/2001;

- CV-JUL02: instalado em casa de vegetação em 31/07/2002.

Utilizou-se o delineamento de blocos ao acaso, com cinco repetições, no primeiro e segundo experimentos, sendo cada genitor disposto em dois vasos e cada geração $F_{2}$ em seis vasos, distribuídos aleatoriamente dentro de cada repetição. No terceiro experimento utilizou-se o delineamento inteiramente casualizado, com dez repetições (vasos) para cada genitor e 30 repetições (vasos) para cada geração $F_{2}$. Os tratamentos constituiram-se de 15 genótipos (cinco genitores e dez populações segregantes em $F_{2}$ ). Avaliaram-se 50 plantas de cada genitor (dez vasos) e 150 plantas de cada geração $F_{2}$ (30 vasos), num total de 1.750 plantas por experimento (totalizando 350 vasos).

Os vasos foram irrigados manualmente, diariamente ou quando necessário (de preferência no período da manhã), utilizando-se uma mangueira, em cuja extremidade adaptouse uma ponteira em forma de chuveiro, para proporcionar uma irrigação mais uniforme. A irrigação foi normal até 15 dias após a emergência, quando então passou a se limitar a quantidade de água, a fim de provocar um pequeno estresse hídrico nas plantas e acentuar a 
manifestação dos sintomas foliares da PVR. Na casa de vegetação, em 2001, fez-se o acompanhamento do teor de umidade do solo com um tensiômetro, instalado a $10 \mathrm{~cm}$ de profundidade, procurando-se mantê-la, no mínimo, a $-22,0 \mathrm{~cm}$ de $\mathrm{Hg}$ (cerca de -0,3 atm), após os 15 dias da emergência. Em 2002 não se limitou a quantidade de água fornecida às plantas, procurando-se manter a umidade do solo, no mínimo, a -4 cm de $\mathrm{Hg}$ (cerca de -0,05 atm).

Diariamente, foram anotadas as temperaturas máxima e mínima, e as temperaturas do ar e do solo (entre as 15 e 16 horas). Em 2001, a temperatura do solo foi medida em cada uma das repetições, com termômetros comuns, cuja extremidade do bulbo foi enterrada a $5 \mathrm{~cm}$ de profundidade (profundidade de colocação do inóculo). No segundo experimento da casa de vegetação (CV-JUL02) acompanhou-se a temperatura mínima e máxima do solo, com termômetro digital instalado a $4 \mathrm{~cm}$ de profundidade, apenas no ponto de maior temperatura (conforme observado em 2001).

No experimento da casa de vegetação em 2002 (CV-JUL02), no dia da emergência procedeu-se à aplicação de inoculante (Bradyrhizobium japonicum), diluindo-se $10 \mathrm{~mL}$ de inoculante oleoso Noctin (Síntesis Química, Buenos Aires) em cinco litros de água, volume este que foi aplicado com regador em cada bancada (70 vasos). Cinco dias após a emergência também foram aplicadas cerca de $5 \mathrm{~g}$ de sulfato de amônio em cada vaso, para prevenir possível deficiência de Nitrogênio causada pelo excesso de umidade do solo.

Quando necessário, fez-se o controle de insetos (mosca branca, tripes e ácaros) com inseticidas apropriados.

Até o término das avaliações dos sintomas foliares da PVR, para o controle de oídio foi utilizado bicarbonato de sódio (na concentração de 1\%), no início do aparecimento dos sintomas desta doença. Após o término das avaliações, quando necessário, foi utilizado o fungicida Score (difenoconazole), na concentração de 1,0 mL por litro de água.

\subsubsection{Avaliação dos sintomas da PVR}

No experimento com a geração $F_{2}$ no telado (CV-JUL01) foram avaliados os sintomas radiculares e os sintomas foliares, enquanto na casa de vegetação (CV-SET01 e CV-JUL02) avaliaram-se somente os sintomas foliares, assim como nos testes de inoculação.

Os sintomas radiculares foram avaliados um dia após a emergência medindo-se o comprimento das lesões $(\mathrm{mm})$ e a severidade dos sintomas, na raiz principal das plantas arrancadas durante $o$ desbaste, com base na seguinte escala de notas:

$\mathbf{1}=$ ausência de sintomas radiculares visíveis;

$\mathbf{2}=$ leve desenvolvimento dos sintomas, com presença de pequenas lesões em forma de listas 
ou pontos marrom-avermelhados, formando uma área contínua passível de ter seu comprimento medido (extensão inferior a $5 \mathrm{~mm}$ );

$\mathbf{3}=$ moderado desenvolvimento dos sintomas, com presença de lesões de coloração marromavermelhada se estendendo superficialmente por vários milímetros (extensão superior a $5 \mathrm{~mm}$ ), porém sem circundar uniformente a raiz;

4= elevado desenvolvimento dos sintomas, com presença de lesões de coloração marromescura ou negra, se estendendo profundamente por vários milímetros (extensão superior a 5 $\mathrm{mm}$ ) e circundando toda a raiz;

$\mathbf{5}=$ severo desenvolvimento dos sintomas, com a raiz principal totalmente necrosada (coloração negra) desde a região de início da lesão até a sua extremidade (coifa).

A severidade dos sintomas foliares da doença foi avaliada segundo a escala de notas utilizada por Hartman et al. (1997), modificada para o seguinte:

$\mathbf{1}=$ ausência de sintomas foliares visíveis;

$\mathbf{2}=$ leve desenvolvimento dos sintomas, com clorose em mosaico, e deformação ou encarquilhamento dos folíolos;

$\mathbf{3}=$ moderado desenvolvimento dos sintomas, com clorose internerval e necrose na borda dos folíolos;

4= elevado desenvolvimento dos sintomas, com clorose e necrose internerval (até $50 \%$ de área foliar afetada por necrose);

$\mathbf{5}=$ severo desenvolvimento dos sintomas, com clorose e necrose internerval e/ou plantas mortas ou severa restrição no desenvolvimento das plantas (51 a 100\% de área foliar afetada por necrose).

Em 2001, no telado, a avaliação da severidade dos sintomas foliares foi efetuada aos 30 e 40 dias após a emergência, enquanto que na casa de vegetação somente aos 30 dias após a emergência, considerando-se o folíolo com sintomas mais intensos em ambos. Em 2002 (CV-JUL02) as plantas foram avaliadas a cada três ou quatro dias, após o aparecimento dos primeiros sintomas, procedendo-se a oito avaliações entre os 14 e 37 dias após a emergência, dando-se uma nota para o folíolo com sintomas mais intensos e outra para o aspecto geral da planta, mas somente os dados da última avaliação foram utilizados nas análises.

A incidência da doença foi avaliada pela contagem do número de plantas com sintomas foliares da doença, manifestada pela presença de clorose ou necrose internerval (nota de severidade dos sintomas foliares superior a 1), dentro de cada vaso (cinco plantas), e após foi calculada a porcentagem de incidência da doença.

Nos testes de inoculação foram utilizados os mesmos procedimentos para avaliação dos sintomas foliares da PVR, alterando-se apenas a época de avaliação. 


\subsubsection{Análises de variância com a geração $F_{2}$}

Fez-se a análise prévia de resíduos para todas as variáveis analisadas, utilizando-se o teste do $F_{\max }$. de Hartley para verificação da homogeneidade de variâncias (David, 1952) e o teste de Shapiro-Wilk para verificação da presença de normalidade. Foi considerado que as variâncias foram homogêneas e que os resíduos apresentaram distribuição normal quando os testes efetuados deram resultado não-significativo a $5 \%$ de probabilidade. Esta análises foram realizadas segundo os procedimentos de Garcia et al. (2001). Como os números de parcelas de genitores e de cruzamentos $F_{2}$ foram diferentes, calculou-se a média harmônica do número de parcelas, a qual foi utilizada para se proceder ao teste do $F_{\max }$. de Hartley de forma aproximada. No experimento conduzido no delineamento inteiramente casualizado, adicionalmente, também se aplicou o teste de Bartlett para verificar a homogeneidade de variâncias de tratamentos (genótipos), o qual foi efetuado por meio do comando "means tratamentos/hovtest=Bartlett" do programa SAS (SAS Institute, 1999).

As médias de parcelas (vasos) para o comprimento das lesões nas raízes e para a severidade dos sintomas radiculares (somente no experimento com a geração $F_{2}$ conduzido no telado) e foliares foram utilizadas para as análises de variância. Os dados de comprimento das

lesões nas raízes $(\mathrm{mm})$ foram transformados para $\sqrt{\mathrm{x}+0,5}$, assim como os dados obtidos na forma de notas, quando necessário.

Para a análise de variância da incidência da doença também foi considerada como parcela experimental cada vaso contendo cinco plantas $F_{2}$ ou dos genitores. Em seguida, foi calculada a porcentagem de plantas com sintomas (incidência) em cada parcela (vaso).

Também foi calculado um índice de doença (ID) para cada parcela (vaso), multiplicando-se os valores de incidência (I) e de severidade média da doença (S) na parcela e dividindo-os pela nota máxima [ID $=(I \times S) / 5]$, de maneira semelhante a Njiti et al. (1996). Estes dados, quando necessário, foram transformados para arco seno $\sqrt{\mathrm{x} / 100}$.

Os esquemas das análises de variância estão apresentados nas Tabelas 2 e 3 . Os efeitos de genótipos foram considerados como fixos e, no caso dos experimentos em blocos ao acaso, os efeitos de blocos e vasos dentro de genótipos como aleatórios. Utilizou-se o teste de homogeneidade de variâncias de Bartlett (Steel \& Torrie, 1980) para verificar se os resíduos das diferentes fontes de variação foram homogêneos.

Para todas as variáveis analisadas, as médias de tratamentos foram comparadas utilizando-se a decomposição dos graus de liberdade da fonte de variação genótipos em contrastes ortogonais, analisando-se sua significância pelo teste $F$, a $5 \%$ e $1 \%$ de probabilidade. Os contrastes ortogonais entre médias foram estabelecidos da seguinte forma: 
1) Genitores vs. Cruzamentos $F_{2}$;

2) ('Forrest' + 'Conquista') vs. demais Genitores: grupo do genitores tidos como resistentes a PVR contra o grupo dos demais, considerados como "não-resistentes";

3) 'Forrest' vs. 'Conquista': para verificar diferenças entre genitores considerados resistentes;

4) ('Cristalina' + 'Estrela') vs. 'IAC-4': grupo dos genitores suscetíveis contra o genitor tido como moderadamente resistente;

5) 'Cristalina' vs. 'Estrela': para verificar diferenças entre os genitores considerados suscetíveis a PVR;

6) ('Conquista' x 'Forrest') vs. demais Cruzamentos: cruzamento entre os dois genitores tidos como resistentes contra os demais cruzamentos $F_{2}$;

7) Cruzamentos "Suscetíveis" vs. Cruzamentos "Resistentes": cruzamentos envolvendo genitores "não-resistentes" ('Cristalina', 'Estrela' ou 'IAC-4') contra os cruzamentos envolvendo um genitor tido como resistente ('Conquista' ou 'Forrest');

8) ('Cristalina'x'IAC-4' + 'Cristalina'x'Estrela') vs. ('IAC-4'x'Estrela'): cruzamentos envolvendo 'Cristalina' contra o cruzamento do outro genitor suscetível com o moderadamente resistente;

9) ('Cristalina' $x$ 'IAC-4') vs. ('Cristalina' $x$ 'Estrela'): cruzamento envolvendo 'Cristalina' com o genitor considerado moderadamente resistente contra 'Cristalina' com o outro genitor suscetível;

10) ('Conquista'x'Cristalina' + 'Conquista'x'IAC-4' + 'Conquista'x'Estrela') vs. ('Forrest'x 'Cristalina' + 'Forrest'x'IAC-4' + 'Forrest'x'Estrela'): cruzamentos envolvendo 'Conquista' contra os cruzamentos envolvendo 'Forrest';

11) ('Conquista'x'Cristalina' + 'Conquista'x'Estrela') vs. ('Conquista'x'IAC-4'): cruzamentos entre 'Conquista' com os genitores suscetíveis contra o cruzamento com o genitor moderadamente resistente;

12) ('Conquista' x 'Cristalina') vs. ('Conquista' x 'Estrela'): cruzamento de 'Conquista' com um genitor suscetível contra o cruzamento com o outro genitor suscetível;

13) ('Forrest'x'Cristalina' + 'Forrest'x'Estrela') vs. ('Forrest' $x$ 'IAC-4'): cruzamentos entre 'Forrest' com os genitores suscetíveis contra o cruzamento com o genitor moderadamente resistente;

14) ('Forrest' $x$ 'Cristalina') vs. ('Forrest' $x$ 'Estrela'): cruzamento de 'Forrest' com um genitor suscetível contra o cruzamento com o outro genitor suscetível.

As análises estatísticas foram realizadas com auxílio dos programas SAS (SAS Institute, 1999) e Excel (Microsoft ${ }^{\circledR}$ Excel 97). Este último foi utilizado para o preparo dos dados para a análise estatística, assim como para o cálculo dos níveis de significância do teste $\mathrm{F}$ não fornecidos corretamente pelo SAS, evitando-se, assim, a interpolação harmônica manual nas tabelas dos valores de $\mathrm{F}$. 


\subsubsection{Análise dialélica de Jinks-Hayman para a geração $F_{2}$}

\subsubsection{Análises de variâncias e covariâncias}

Inicialmente, procedeu-se à análise de variância das tabelas dialélicas obtidas, seguindo-se os procedimentos de Ramalho et al. (1993), cuja análise é derivada de tabelas dialélicas completas, segundo proposto por Hayman (1954b), a qual foi adaptada para meias tabelas por Jones (1965). Utilizando-se os dados médios de repetições, efetuou-se um novo cálculo da soma de quadrados da fonte de variação "genótipos" e outra decomposição desta em: "a" - efeito aditivo dos genes, e "b" - efeito de dominância dos genes. A fonte de variação "b", por sua vez, foi decomposta nos seguintes componentes: "b $b_{1}$ " - diferença entre a média dos genitores e a média dos cruzamentos, o qual será significativo se os desvios de dominância forem predominantes em uma direção (negativos ou positivos); " $\mathrm{b}_{2}$ " - proporção de alelos dominantes nos genitores, o qual será significativo se alguns genitores apresentarem maior proporção de alelos dominantes do que outros, indicando heterogeneidade entre os desvios de dominância das progênies de meios irmãos; " $b_{3}$ " - desvios de dominância específicos para cada cruzamento, cuja significância indica heterogeneidade entre estes, ou seja, a presença de capacidade específica de combinação propriamente dita.

Os quadrados médios destas fontes de variação foram testados com o quadrado médio do resíduo geral obtido nas análises de maiância iniciais (item 3.1.7), o qual foi dividido pela média harmônica dos números de parcelas (experimentos em blocos ao acaso) ou repetições (experimento inteiramente casualizado), de genitores e cruzamentos $F_{2}$, ou seja, dividido por 18 .

As somas de quadrados e os respectivos graus de liberdade de cada fonte de variação foram obtidas da seguinte forma:

$$
S Q_{\text {genótipos }}=\sum Y_{i i}^{2}+\sum_{i<j} Y_{i j}^{2}-\frac{2\left(Y_{. . .}\right)^{2}}{n(n+1)}
$$

$\operatorname{com}\left[\frac{\mathrm{n}(\mathrm{n}+1)}{2}-1\right]$ graus de liberdade, em que:

$Y_{i i}=Y_{i j}$, para $i=j$, ou seja, corresponde aos valores da diagonal dos genitores;

$Y_{. .}=\sum_{i \leq j} Y_{i j}$, ou seja, corresponde a soma dos valores da diagonal dos genitores mais os valores acima desta. 


$$
S Q_{a}=\frac{\sum_{i} A_{i}^{2}-\frac{\left(\sum_{i} A_{i}\right)^{2}}{n}}{n+2}
$$

com (n-1) graus de liberdade, em que:

$A_{i}=Y_{i}+2 Y_{i i}$, para a résima linha da tabela dialélica, após completada com os valores de $Y_{i j}$ (para $\mathrm{i}<\mathrm{j}$ ) nos locais dos recíprocos $\mathrm{Y}_{\mathrm{ij}}$ (para $\mathrm{i}>\mathrm{j}$ ) correspondentes, em que:

$\mathrm{Y}_{\mathrm{i} .}=\sum_{\mathrm{i}<\mathrm{j}} \mathrm{Y}_{\mathrm{ij}}$, ou seja, corresponde a soma dos valores dos cruzamentos da i-ésima linha.

$$
S Q_{b_{1}}=\frac{[2 Y . .-(n+1) Y]^{2}}{n\left(n^{2}-1\right)}
$$

com um grau de liberdade, em que:

$Y=\sum_{i=j} Y_{i i}$

$$
S Q_{b_{2}}=\frac{\sum_{i} D_{i}^{2}-\frac{\left(\sum_{i} D_{i}\right)^{2}}{n}}{n^{2}-4}
$$

com (n-1) graus de liberdade, em que:

$D_{i}=2 A_{i}-(n+2) Y_{i i}$, para a i-ésima linha da tabela dialélica.

$$
S Q_{\mathrm{b}_{3}}=S Q_{\text {genótipos }}-\left(\mathrm{SQ}_{\mathrm{a}}+\mathrm{SQ}_{\mathrm{b}_{1}}+\mathrm{SQ}_{\mathrm{b}_{2}}\right)
$$

com $\left[\frac{\mathrm{n}(\mathrm{n}-3)}{2}\right]$ graus de liberdade;

$$
S Q_{b}=S Q_{b_{1}}+S Q_{b_{2}}+S Q_{b_{3}}
$$

com $\left[\frac{\mathrm{n}(\mathrm{n}-1)}{2}\right]$ graus de liberdade.

Após esta análise de variância inicial procedeu-se à análise dialélica dos dados obtidos com a geração $F_{2}$ segundo as bases teóricas desenvolvidas para a geração $F_{1}$ (Hayman, 1954a), adaptadas para a geração $F_{2}$, utilizando-se meias tabelas dialélicas com " $n$ " genitores (Santos, 1984; Singh \& Singh, 1984a; Freire Filho, 1988). A partir destas tabelas foram 
estimadas as seguintes variâncias e covariâncias para cada variável analisada (Cruz \& Regazzi, 1997):

a) Variância entre genitores $\left(V_{g}\right)$ :

$$
\hat{V}_{g}=\frac{1}{n-1}\left(\sum_{i} Y_{i i}^{2}-\frac{1}{n} Y_{g}^{2}\right)
$$

b) Variância dentro de cada "i" linha da tabela dialélica $\left(V_{i}\right)$ :

$$
\hat{V}_{i}=\frac{1}{n-1}\left(\sum_{j} Y_{i j}^{2}-\frac{1}{n} Y_{i}^{2}\right)
$$

c) Média das variâncias estimadas dentro das linhas da tabela dialélica $(\bar{\nabla})$ :

$$
\overline{\hat{V}}=\frac{1}{n}\left(\sum_{i} \hat{V}_{i}\right)
$$

d) Variância entre as médias das linhas da tabela dialélica $\left(V_{M}\right)$ :

$$
\hat{V}_{M}=\frac{1}{n-1}\left[\sum_{i} \bar{Y}_{i .}^{2}-\frac{1}{n}\left(\sum_{i} \bar{Y}_{i .}\right)^{2}\right]
$$

e) Covariância entre a diagonal dos genitores e os genótipos da i-ésima linha da tabela dialélica $\left(\mathrm{W}_{\mathrm{i}}\right)$ :

$$
\hat{W}_{i}=\frac{1}{n-1}\left[\left(\sum_{j} Y_{j j} Y_{i j}\right)-\frac{1}{n}\left(\sum_{j} Y_{j j} \sum_{j} Y_{i j}\right)\right]
$$

f) Média das covariâncias estimadas entre a diagonal dos genitores e os genótipos da iésima linha da tabela dialélica $(\overline{\mathrm{W}})$ :

$$
\overline{\hat{W}}=\frac{1}{n}\left(\sum_{i} \hat{W}_{i}\right)
$$

Em seguida foi efetuada a análise gráfica, com base na regressão linear entre os valores de $\hat{W}_{i}$ e $\hat{V}_{i}$, na qual as equações das estimativas de $W_{i}=a+b V_{i}$ e $W_{i}^{2}=V_{g} V_{i}$ permitem, respectivamente, a construção da reta e da parábola limitante. As estimativas dos 
valores de "a" (intercepto) e "b" (coeficiente angular) foram obtidas pelas seguintes expressões (Cruz \& Regazzi, 1997):

$$
\begin{aligned}
& \hat{a}=\overline{\hat{W}}_{i}-\hat{b} \overline{\hat{V}}_{i} \\
& \hat{b}=\frac{\operatorname{Côv}\left(\hat{W}_{i}, \hat{V}_{i}\right)}{\hat{V}\left(\hat{V}_{i}\right)}
\end{aligned}
$$

A estimativa do erro de $b\left(s_{b}\right)$ foi obtida pela seguinte expressão (Singh \& Chaudhary, 1979):

$$
S_{b}=\sqrt{\frac{\hat{V}\left(\hat{W}_{i}\right)-\left[\hat{b} \operatorname{Cov}\left(\hat{W}_{i}, \hat{V}_{i}\right)\right.}{(n-2) \hat{V}\left(\hat{V}_{i}\right)}}
$$

Os testes de suficiência do modelo aditivo-dominante, ou seja, a verificação se os dados de cada variável analisada atenderam às restrições impostas para a utilização do modelo genético de Jinks-Hayman, foram efetuados de duas maneiras (Hayman, 1954a; Cruz \& Regazzi, 1997): no primeiro teste, aplicado somente aos experimentos em blocos ao acaso, as variâncias e covariâncias foram calculadas para cada linha em cada uma das cinco repetições e, em seguida, a variação entre os valores de $\hat{W}_{i}-\hat{V}_{i}$ de cada repetição foi avaliada por meio de uma análise de variância, em blocos ao acaso, tendo-se como fontes de variação os blocos e as linhas de cada tabela dialélica; se o teste F foi não-significativo para o efeito de "linhas", aceitou-se a hipótese de homogeneidade entre os valores de $\hat{W}_{i}-\hat{V}_{i}$, atendendo-se æ̀s pressuposições do modelo. No segundo teste, a significância do coeficiente angular da reta (b), obtido pela regressão linear entre os valores de $\hat{W}_{i}$ e $\hat{V}_{i}$ após a rotação de 45o no eixo do gráfico $\left(H_{0}: b^{\prime}=0\right.$ vs. $\left.H_{1}: b^{\prime} 0\right)$, foi testada utilizando-se um teste $F\left(=" t^{2}\right.$ ") com 1 e "n-2" graus de liberdade:

$$
F=t^{2}=\frac{n-2}{4}\left\{\frac{\left[\hat{V}\left(\hat{V}_{i}\right)-\hat{V}\left(\hat{W}_{i}\right)\right]^{2}}{\left[\hat{V}\left(\hat{W}_{i}\right) \hat{V}\left(\hat{V}_{i}\right)\right]-\operatorname{Covv}^{2}\left(\hat{V}_{i}, \hat{W}_{i}\right)}\right\}
$$

Um terceiro teste, conforme indicado por Cruz \& Regazzi (1997), também foi realizado, no qual foi testado se o coeficiente angular "b" foi igual a $1,0\left(H_{0}: b=1,0\right.$ vs. $\left.H: b \quad 1,0\right)$, utilizando-se a análise de regressão de $\hat{W}_{i}$ em função de $\hat{V}_{i}$ para se obter o valor do quadrado 
médio do desvio da regressão $\left(\mathrm{QM}_{\text {desvio }}\right)$ e depois a variância de "b" $[\hat{\mathrm{V}}(\hat{\mathrm{b}})]$, procedendo-se então a um teste "t" com "n-2" graus de liberdade:

$$
t=\frac{\hat{b}-1}{\sqrt{\hat{V}(\hat{b})}}
$$

em que:

$\hat{V}(\hat{b})=\frac{Q M_{\text {desvio }}}{\sum_{i}\left(\hat{V}_{i}-\hat{V}\right)^{2}}$

Se o coeficiente angular da reta foi diferente de zero e igual a 1,0, houve atendimento das restrições do modelo.

Caso um destes testes tenha demonstrado o não-atendimento das restrições do modelo para alguma variável, efetuou-se a análise com subtabelas dialélicas que atenderam a estas restrições.

O gráfico obtido com base na regressão linear entre os valores de $\hat{W}_{i}$ e $\hat{V}_{i}$ foi utilizado para se obter uma estimativa aproximada do grau médio de dominância. Segundo Singh \& Singh (1984b), como o grau médio de dominância em $F_{2}$ é reduzido à metade daquele observado em $F_{1}$, as seguintes interpretações são sugeridas, já que nesta análise não se considera o efeito de ambiente:

a) Dominância completa: se a interseção da reta de regressão com a ordenada (eixo $\hat{W}_{\mathrm{i}}$ ) ocorrer no ponto "AB/2";

b) Dominância parcial: se a interseção ocorrer entre "B" e "AB/2";

c) Sobredominância: se a interseção ocorrer abaixo de "AB/2".

$O$ ponto "A" corresponde à interseção da reta de regressão com a ordenada e o ponto " $B$ " à interseção da reta paralela à reta de regressão, e tangente à parábola limitante, com a ordenada.

Para que estas estimativas feitas graficamente ficassem menos distorcidas, procurou-se manter a mesma escala para os eixos das abcissas e das ordenadas no gráfico de regressão de $\hat{W}_{i}$ em função de $\hat{V}_{i}$. 


\subsubsection{Estimativa dos componentes de variação genética}

Os seguintes componentes de variação genética foram calculados:

D : estimativa do componente de variância devido aos efeitos gênicos aditivos;

$\hat{\mathrm{H}}_{1}$ : estimativa do componente de variância devido aos efeitos de dominância dos genes;

$\hat{\mathrm{H}}_{2}$ : estimativa do componente de variância genética dominante corrigido para a distribuição gênica; indica a assimetria dos efeitos positivos e negativos dos genes; teoricamente, $\hat{H}_{1}>\hat{H}_{2}$; se $\hat{H}_{1}=\hat{H}_{2}$, isto indica simetria entre os genes de efeito positivo e aqueles de efeito negativo;

$\hat{\mathrm{F}}$ : estimativa do componente genético correspondente à covariância entre os efeitos aditivos e dominantes dos genes; indica a freqüência relativa dos alelos dominantes e recessivos no conjunto dos genitores; o seu valor será positivo se os alelos dominantes estiverem em maior frequência que os recessivos e, negativo, se os alelos recessivos predominarem.

Para a estimação destes componentes de variação genética foram utilizadas as seguintes fórmulas, adaptadas para meias tabelas dialélicas, com dados provenientes da geração $F_{2}$, segundo Singh \& Singh (1984a):

$$
\begin{gathered}
\hat{D}=\hat{V}_{g}-E_{0} \\
\hat{H}_{1}=4 \hat{V}_{g}+16 \overline{\hat{V}}_{i}-16 \overline{\hat{W}}_{i}-\frac{4\left[n E_{0}+4(n-1) E_{2}\right]}{n} \\
\hat{H}_{2}=16 \overline{\hat{V}}_{i}-16 \hat{V}_{M}-\frac{16\left[(n-1) E_{0}+\left(n^{2}-2 n+1\right) E_{2}\right]}{n^{2}} \\
\hat{F}=4 \hat{V}_{g}-8 \overline{\hat{W}}-\frac{4(n-2) E_{0}}{n}
\end{gathered}
$$

Como para cada genitor foram avaliadas dez parcelas (cada uma representada por um vaso com cinco plantas) e para cada população $F_{2} 30$ parcelas, respectivamente duas e seis parcelas (vasos) por repetição, no caso de blocos ao acaso, utilizaram-se os resíduos específicos, representados por $E_{0}$ (quadrado médio da fonte de variação blocos $\mathrm{x}$ vasos de genitores dividido por 10 ) e $E_{2}$ (quadrado médio da fonte de variação blocos $x$ vasos de cruzamentos $F_{2}$ dividido por 30 ). Estes procedimentos foram semelhantes para o experimento inteiramente casualizado (CV-JUL02), utilizando-se também os resíduos específicos $E_{0}$ e $E_{2}$, 
pois foram utilizadas 10 e 30 repetições, respectivamente, para genitores e cruzamentos $F_{2}$.

O componente $\hat{h}^{2}$ não foi estimado, visto que Jinks (1956), Hayman (1958) e Singh \& Singh (1984a), assim como outros autores que trabalharam com dados da geração $F_{2}$ (Verhalen \& Murray, 1969; Park \& Davis, 1976; Santos, 1984; Freire Filho, 1988; Lopes, 2001) e também Mather e Jinks (1982) não fazem referência a este componente. Além disso, não se encontrou na literatura uma fórmula para a estimativa deste componente para meias tabelas dialélicas com a geração $F_{2}$ que leve em consideração os resíduos específicos $E_{0}$ e $E_{2}$. Como este componente é utilizado apenas para o cálculo da estimativa do número de genes que exibem dominância, este foi então calculado por meio do número de fatores efetivos $(\mathrm{N})$ de Jinks (1954), adaptado para a geração $F_{2}$. Por outro lado, como Ferreira (1988) cita que o componente $\hat{\mathrm{h}}^{2}$, em tabelas dialélicas completas, não necessita de um termo de correção para o efeito de ambiente, então, o número de genes que exibem dominância foi calculado de forma idêntica ao número de fatores efetivos de Jinks (1954).

O desvio padrão de cada componente genético foi estimado a partir da seguinte variância (Hayman, 1954a):

$$
\hat{s}^{2}=\frac{\hat{V}\left(\hat{W}_{i}-\hat{V}_{i}\right)}{2}
$$

Essa variância foi então multiplicada pelos coeficientes específicos para cada componente genético, fornecidos para a geração $F_{2}$ por Hayman (1958, Tabela 3 ) e corrigidos para meias tabelas dialélicas, e após se extraiu a raiz quadrada do valor obtido para se obter o respectivo desvio padrão de cada componente. A correção do valor de cada coeficiente para meias tabelas dialélicas foi efetuada a partir da diferença observada, em porcentagem, entre os valores dos coeficientes específicos de cada componente, para o tamanho de dialelo consideradado ( $5 \times 5$ ou $4 \times 4)$, fornecidos para a geração $F_{1}$ com dados de tabela dialélica completa por Hayman (1954a, Tabela 1) e, com dados de meia tabela, também para a geração $F_{1}$, por Ferreira (1985, Tabela 2); o fator de correção obtido para cada coeficiente foi multiplicado pelo coeficiente fornecido para a geração $F_{2}$ (Hayman, 1958, Tabela 3). A significância de cada componente foi, então, testada pelo teste "t", com "n-2" graus de liberdade, sendo que o valor de "t" foi obtido pela divisão da estimativa de cada componente pelo seu respectivo desvio padrão (Singh \& Chaudhary, 1979). 


\subsubsection{Estimativa dos parâmetros genéticos}

A partir das estimativas dos componentes genéticos $D, H_{1}, H_{2}$ e $F$ foram então estimados os seguintes parâmetros, cujas interpretações se referem exclusivamente ao grupo de genitores utilizados no presente estudo (modelo fixo):

1) Grau médio de dominância, fornecido pela expressão de Hayman (1954a, 1958):

$$
g \hat{m} d=\sqrt{\frac{\hat{H}_{1}}{\hat{D}}}
$$

A interpretação do valor obtido foi a seguinte:

- Ausência de dominância: ĝ̂md $=0$;

- Dominância parcial: $0<\mathrm{gmid}<1$;

- Dominância completa: $\mathrm{g} \hat{\mathrm{md}}=1$;

- Sobredominância: gîmd >1.

2) Proporção entre alelos dominantes $\left(K_{D}\right)$ e recessivos $\left(K_{R}\right)$ nos genitores, estimada pela expressão fornecida por Hayman 1954a):

$$
\frac{\hat{K}_{D}}{\hat{K}_{R}}=\frac{\sqrt{4 \hat{D} \hat{H}_{1}}+\hat{F}}{\sqrt{4 \hat{D} \hat{H}_{1}}-\hat{F}},
$$

se:

$\frac{\hat{\mathrm{K}}_{\mathrm{D}}}{\hat{\mathrm{K}}_{\mathrm{R}}} \cong 1$ : indica distribuição uniforme dos alelos dominantes e recessivos nos genitores;

$\frac{\hat{K}_{D}}{\hat{K}_{R}}>1$ : indica maior freqüência de alelos dominantes em relação aos recessivos;

$\frac{\hat{\mathrm{K}}_{\mathrm{D}}}{\hat{\mathrm{K}}_{\mathrm{R}}}<1$ : indica maior freqüência de alelos recessivos em relação aos dominantes.

Esta relação exige que os locos tenham efeitos iguais sobre a expressão do caráter (Santos, 1984). Porém, este parâmetro não é afetado se a dominância é no sentido de aumentar o caráter em parte dos locos e reduzir em outros (Vencovsky \& Barriga, 1992).

3) Produto das freqüências médias dos alelos de efeitos positivos e negativos nos locos em que ocorre dominância (simetria), estimado pela expressão de Hayman (1954a):

$$
\overline{i v}=\frac{\hat{H}_{2}}{4 \hat{H}_{1}}
$$


Se o valor de $\overline{\mathrm{i} v}$ for igual a 0,25 (valor máximo teórico), os alelos positivos e negativos, dos locos em que ocorre dominância, estão distribuídos uniformemente (simetricamente) nos genitores. Valores inferiores a 0,25 indicam distribuição desuniforme dos alelos positivos e negativos nos genitores.

4) Constância da relação entre efeitos de dominância (h) e efeitos aditivos (d), estimada pela expressão de Mather \& Jinks (1982, p.258):

$$
(\hat{i}-v) \frac{h}{d}=\sqrt{\frac{\left(\frac{\hat{F}}{2}\right)^{2}}{\hat{D}\left(\hat{H}_{1}-\hat{H}_{2}\right)}}
$$

Quando o valor obtido for próximo ou igual a 1,0, isto indica que a razão entre efeitos de dominância e efeitos aditivos é constante, correspondendo a uma contribuição uniforme de todos os locos para o grau médio de dominância do caráter. Se o valor obtido for próximo de zero, isto indica que os valores de "h" e de "d" variam independentemente nos diferentes locos. Esta expressão só tem validade quando a freqüência dos alelos dominantes e recessivos for diferente (Santos, 1984).

5) Número de fatores efetivos $(\hat{N})$, estimado a partir da fórmula de Jinks (1954), adaptada para a geração $F_{2}$ (Verhalen \& Murray, 1969; Santos, 1984):

$$
\hat{\mathrm{N}}=\frac{16\left(\mathrm{ML}_{2}-\mathrm{ML}_{0}\right)^{2}}{\hat{\mathrm{H}}_{2}} \text {, }
$$

em que:

$\mathrm{ML}_{2}$ é a média dos cruzamentos $F_{2}$;

$\mathrm{ML}_{0}$ é a média dos genitores.

O valor de $\hat{\mathrm{N}}$ será subestimado se os efeitos de dominância dos locos não forem iguais em magnitude e direção e se a distribuição dos genes nos genitores for correlacionada, além de que o valor obtido considera apenas os locos que exibem dominância (Jinks, 1954).

6) Herdabilidades no sentido restrito $\left(h_{r}^{2}\right)$ e amplo $\left(h_{a}^{2}\right)$, calculadas em nível de média de repetições, segundo as expressões de Mather \& Jinks (1982):

$$
\hat{h}_{\mathrm{r}}^{2}=\frac{\frac{\hat{D}}{2}+\frac{\hat{H}_{1}}{2}-\frac{\hat{H}_{2}}{2}-\frac{\hat{F}}{2}}{\frac{\hat{D}}{2}+\frac{\hat{H}_{1}}{2}-\frac{\hat{H}_{2}}{4}-\frac{\hat{F}}{2}+\frac{\hat{E}}{r}}
$$




$$
\hat{\mathrm{h}}_{\mathrm{a}}^{2}=\frac{\frac{\hat{\mathrm{D}}}{2}+\frac{\hat{\mathrm{H}}_{1}}{2}-\frac{\hat{\mathrm{H}}_{2}}{4}-\frac{\hat{\mathrm{F}}}{2}}{\frac{\hat{\mathrm{D}}}{2}+\frac{\hat{\mathrm{H}}_{1}}{2}-\frac{\hat{\mathrm{H}}_{2}}{4}-\frac{\hat{\mathrm{F}}}{2}+\frac{\hat{\mathrm{E}}}{\mathrm{r}}}
$$

Para os experimentos em blocos ao acaso (2001) o valor de $\hat{E} / r$ foi obtido a partir da divisão do quadrado médio do resíduo geral (interação blocos $x$ vasos) pelo número de repetições, ou seja, dividido por cinco. No experimento inteiramente casualizado (2002), o valor de $\hat{E} / r$ foi obtido a partir da divisão do quadrado médio do resíduo geral pela média harmônica do número de repetições de genitores e cruzamentos $F_{2}$, ou seja, dividido por 18. A média harmônica $\left(H_{y}\right)$ foi obtida pela seguinte expressão (Sokal \& Rolf, 1995):

$$
\frac{1}{\mathrm{H}_{\mathrm{y}}}=\frac{1}{\mathrm{n}} \sum \frac{1}{\mathrm{y}}
$$

Além destes parâmetros genéticos também foram obtidas as seguintes informações genéticas:

1) Relação entre alelos favoráveis e dominância (r):

A média genotípica do caráter pode ser aumentada pelo efeito de alelos dominantes ou recessivos, sendo que uma maneira de medir esta æsociação é utilizar a correlação entre o valor médio do genitor $Y_{i i}$ e o seu valor de $\hat{W}_{i}+\hat{V}_{i}$, o qual representa uma medida da sua concentração de alelos dominantes ou recessivos. Esta correlação é estimada pela seguinte expressão (Cruz \& Regazzi, 1997):

$$
r=\frac{\operatorname{Côv}\left(Y_{i i}, \hat{W}+\hat{V}\right)}{\sqrt{\hat{V}(\hat{W}+\hat{V}) \hat{V}_{g}}}
$$

Valor de "r" próximo de 1 indica que os alelos recessivos, em sua maioria, contribuem para aumentar a média do caráter; se próximo de -1 , os alelos dominantes é que contribuem para aumentar a média do caráter; e se próximo de zero, há ausência de dominância direcional.

2) Concentração de alelos dominantes e recessivos nos genitores:

Os genitores com maior número de alelos dominantes originarão progênies com variância $\left(\hat{V}_{i}\right)$ mínima entre si, assim como com covariância genitor-progênie $\left(\hat{W}_{i}\right)$ mínima, enquanto que genitores com maior número de alelos recessivos originarão progênies com elevados valores de $\hat{V}_{i}$ e $\hat{W}_{i}$; desta forma, a soma $\hat{W}_{i}+\hat{V}_{i}$ é considerada um indicador da concentração relativa de alelos dominantes e recessivos nos genitores (Cruz \& Regazzi, 1997).

Esta informação é obtida pela observação do gráfico construído previamente com base 
na regressão linear entre os valores de $\hat{W}_{i}$ e $\hat{V}_{i}$, dada pela equação $\hat{W}_{i}=\hat{a}+\hat{b} \hat{V}_{i}$. $A$ distribuição dos genitores ao longo da reta de regressão indica a sua constituição genética para o caráter. Assim, genitores com os menores valores de $\hat{V}_{i}$ e $\hat{W}_{i}$, ou seja, aqueles situados na parte inferior esquerda do gráfico, apresentam maior proporção de alelos dominantes; enquanto que os genitores com os maiores valores de $\hat{V}_{i}$ e $\hat{W}_{i}$, ou seja, aqueles situados na parte superior direita do gráfico, apresentam maior proporção de alelos recessivos. Genitores situados em posição intermediária apresentam proporções equivalentes de alelos dominantes e recessivos.

3) Limites teóricos de seleção:

Quando possível (valor do r $^{2}$ próximo de 1), também foram estimados os limites teóricos de seleção, com base na equação de predição dada pela regressão linear de $Y_{i i}$ em função da soma das covariâncias e variâncias $\left(\hat{\mathrm{W}}_{\mathrm{i}}+\hat{\mathrm{V}}_{\mathrm{i}}\right)$ :

$$
\hat{\mathrm{Y}}_{\mathrm{ii}}=\hat{a}_{0}+\hat{a}_{1}\left(\hat{\mathrm{W}}_{\mathrm{i}}+\hat{\mathrm{V}}_{\mathrm{i}}\right)
$$

sendo:

$$
\begin{aligned}
& \hat{a}_{0}=\bar{Y}_{i i}-a_{1}(\overline{\hat{W}}+\overline{\hat{V}}) \\
& \hat{a}_{1}=\frac{\operatorname{Côv}\left(Y_{i i}, \hat{W}+\hat{V}\right)}{\hat{V}(\hat{W}+\hat{V})}
\end{aligned}
$$

Os valores estimados das variâncias e covariâncias, correspondentes ao genótipo completamente dominante, são $\hat{V}_{D}$ e $\hat{W}_{D}$, e ao genótipo completamente recessivo são $\hat{V}_{R}$ e $\hat{W}_{R}$. Os valores de $\hat{W}_{D}$ e $\hat{W}_{R}$ correspondem às raízes da equação $\hat{W}_{i}^{2}=\frac{\hat{V}_{g}\left(\hat{W}_{i}-\hat{a}\right)}{\hat{b}}$, a qual representa a interseção da reta $\hat{W}_{i}=\hat{a}+\hat{b} \hat{V}_{i}$ com a parábola $\hat{W}_{i}^{2}=\hat{V}_{g} \hat{V}_{i}$. Após a substituição de cada valor de $\hat{W}_{D}$ e $\hat{W}_{R}$ na equação da reta, obtiveram-se os valores de $\hat{V}_{D}$ e $\hat{V}_{R}$. Com isto, foi possível então se estimar os valores do caráter para os genótipos com a máxima concentração de alelos dominantes $\left(\hat{Y}_{D}\right)$ e recessivos $\left(\hat{Y}_{R}\right)$, dados pelas seguintes equações:

$$
\hat{Y}_{D}=\hat{a}_{0}+\hat{a}_{1}\left(\hat{W}_{D}+\hat{V}_{D}\right)
$$




$$
\hat{\mathrm{Y}}_{\mathrm{R}}=\hat{a}_{0}+\hat{a}_{1}\left(\hat{\mathrm{W}}_{\mathrm{R}}+\hat{\mathrm{V}}_{\mathrm{R}}\right)
$$

Quando as análises foram realizadas com dados transformados, os valores obtidos para os limites teóricos de seleção foram apresentados na escala original.

As análises dialélicas foram efetuadas por intermédio de planilhas eletrônicas concebidas no programa Excel (Microsoft ${ }^{\circledR}$ Excel 97), com exceção dos limites teóricos de seleção, os quais foram obtidos utilizando-se o programa Genes (Cruz, 2001).

\subsubsection{Experimento de campo com a geração $F_{3: 2}$}

As plantas $F_{2}$ resistentes ou moderadamente resistentes (nota máxima de severidade dos sintomas foliares da PVR igual a 2) foram conduzidas até o final de seu ciclo e as progênies $F_{3: 2}$ foram semeadas no campo, na safra 2001/2002, para avaliação de suas características agronômicas.

Como critério de seleção, além da segregação para a resistência a PVR também se considerou a segregação para resistência ao cancro da haste da soja (CHS) nos cruzamentos efetuados. Assim, nos cruzamentos 'Conquista' x 'Cristalina', 'Conquista' x 'Estrela', 'Conquista' $x$ 'Forrest', 'Conquista' $x$ 'IAC-4' e 'Estrela' $x$ 'Forrest' foram selecionadas todas as plantas com nota máxima 2. Já para os cruzamentos 'Cristalina' x 'Estrela', 'Cristalina' x 'Forrest', 'Cristalina' $x$ 'IAC-4', 'Estrela' x 'IAC-4' e 'Forrest' x 'IAC-4' foram selecionadas apenas as plantas correspondentes æ̀ covas um e três (ou dois e quatro, na ausência de alguma planta nas posições um e três) de cada vaso e com nota máxima igual a 2. Algumas plantas dos genitores também bram mantidas, a fim de se dispor de sementes com boa qualidade fisiológica para 0 experimento de campo. Todas as plantas foram conduzidas individualmente, sendo cada uma sustentada por um barbante de algodão preso a um arame esticado na parte superior do telado sobre cada fileira de vasos.

A colheita das plantas selecionadas no telado foi encerrada no final de novembro. Cada planta foi colhida individualmente e suas vagens debulhadas manualmente, para evitar o risco de mistura mecânica durante a debulha.

O experimento de campo foi instalado em 05/12/2001, na Estação Experimental Anhembi (Piracicaba-SP). Utilizou-se o delineamento inteiramente casualizado, com parcelas na forma de covas (método "SHDT - Single Hill Descent Thinned" - descendência de uma única

cova desbastada, segundo Vello, 1992), colocando-se de 6 a 12 sementes por cova na semeadura, com espaçamento entre covas de 0,8 x 1,0 m. Após o desbaste, foi deixada apenas 
uma planta por cova.

Este experimento foi composto de 685 parcelas (610 das plantas $F_{3: 2}$ mais 15 parcelas de cada genitor) e as características avaliadas foram: número de dias para o florescimento e para a maturidade, altura da planta, acamamento (escala de 1 a 5), reação ao cancro da haste (escala de 1 a 5), valor agronômico (escala de 1 a 5), produtividade de grãos por planta e as cores da flor, pubescência e vagem.

Como o número de parcelas (covas) de cada cruzamento foi diferente, variando entre 28 e 102, além da análise com todos os dados na forma usual (delineamento inteiramente casualizado com número diferente de repetições), procedeu-se a uma segunda análise, uniformizando-se o número de repetições dentro dos cruzamentos e dentro dos genitores. Para esta uniformização, dentro dos cruzamentos, foram mantidas apenas as plantas provenientes das covas de posições um e três, referentes ao experimento da geração $F_{2}$ no telado, para aqueles cruzamentos em que no procedimento de seleção não havia sido considerado este item durante a seleção, ou seja, aqueles com segregação para resistência a PVR e ao CHS. Após isto, descartando-se também as parcelas perdidas do experimento de campo com a geração $F_{3: 2}$, chegou-se ao número mínimo de 27 repetições (ou covas) em um dos cruzamentos. Assim, nos demais, foram simplesmente descartadas as repetições excedentes. Entre os genitores foram apenas eliminadas as parcelas perdidas no experimento de campo, sendo então uniformizados para o número mínimo de 12 repetições.

\subsection{Utilização de marcadores moleculares}

Esta etapa foi desenvolvida no Laboratório de Genética Molecular do Departamento de Entomologia, Fitopatologia e Zoologia Agrícola da ESALQ/USP. Quando necessário, também foram utilizados equipamentos do Laboratório Central de Biologia Molecular do Departamento de Genética da ESALQ/USP.

Foram utilizadas plantas provenientes da geração $F_{2}$ do cruzamento entre as cultivares MG/BR-46 (Conquista) e FT-Estrela, sendo a primeira considerada resistente a PVR e, a segunda, suscetível.

Para a extração de DNA foi coletada uma folha unifoliolada de cada planta (aos 17 dias após a emergência no telado e aos 10 dias após a emergência na casa de vegetação), no início do aparecimento dos sintomas foliares da PVR. Estas folhas foram acondicionadas em sacos plásticos de $5 \times 8 \mathrm{~cm}$, os quais foram fechados com grampo, identificados e armazenados em "ultrafreezer", a $-80^{\circ} \mathrm{C}$.

A maceração das folhas unifolioladas foi efetuada individualmente, em tubos 
"eppendorf" de 1,5 mL, utilizando-se $\mathrm{N}_{2}$ líquido e uma furadeira elétrica (suspensa em um suporte), cuja broca foi substituída por um pistilo (com encaixe perfeito no fundo do "eppendorf"), inicialmente de plástico (Imprint do Brasil) e depois de aço inox. As amostras foram descongeladas apenas durante a transferência para o "eppendorf" (efetuada com auxílio de uma pinça de ponta lisa), para evitar o seu quebramento. Antes e após a maceração as amostras foram conservadas em recipiente com $\mathrm{N}_{2}$ e, após maceradas, foram novamente colocadas em "ultrafreezer", onde ficaram armazenadas até se proceder àextração.

A extração de DNA seguiu o protocolo CTAB proposto por Saghai-Maroof et al. (1984), com algumas modificações. Após a adição de $700 \mu \mathrm{L}$ de tampão de extração (aquecido a $\left.65^{\circ} \mathrm{C}\right)$, contituído de Tris-HCl pH 7,5 (100 mM), EDTA pH 8,0 (50 mM), NaCl (71 mM), CTAB $(1,0 \% \mathrm{v} / \mathrm{v}), \quad \beta$-mercaptoetanol $(0,02 \% \mathrm{v} / \mathrm{v})$ e água destilada, em cada tubo devidamente identificado, estes foram agitados manualmente e colocados em banho-maria (65을 $\mathrm{C}$, por aproximadamente uma hora, sendo agitados por inversão a cada dez minutos. Ao fim do tempo de banho-maria adicionaram-se $500 \mu \mathrm{L}$ de clorofórmio:álcool isoamílico (24:1) e agitou-se manualmente as amostras, por inversão, durante dez minutos. Em seguida, as amostras foram centrifugadas a $13.000 \mathrm{rpm}$, por 20 minutos, em centrífuga modelo Eppendorf 5415C (Brinkmann Instruments, Westbury, NY). O sobrenadante (fase aquosa) foi então transferido para novos tubos, aos quais se adicionaram $500 \mu \mathrm{L}$ de clorofórmio:álcool isoamílico, procedendo-se à agitação manual, por inversão, durante dez minutos e depois centrifugando-se a $13.000 \mathrm{rpm}$, por 12 minutos. O sobrenadante foi transferido para novos tubos, aos quais se adicionaram $400 \mu \mathrm{L}$ de isopropanol gelado. Em seguida, procedeu-se à homogeneização, por meio de suaves inversões dos tubos, após o que estes foram colocados em congelador $\left(-20^{\circ} \mathrm{C}\right)$ por cerca de três horas, para favorecer a precipitação dos ácidos nucléicos. Após este período, centrifugou-se novamente as amostras, a $13.000 \mathrm{rpm}$ por 20 minutos e, em seguida, descartouse o sobrenadante (fase aquosa), tomando-se o cuidado de não descartar os "pellets". Estes foram então lavados três vezes, pela adição de $100 \mu \mathrm{L}$ de etanol gelado em cada tubo, na concentração de $75 \%$, 90\% e 100\%, respectivamente. Os tubos foram mantidos invertidos, sobre papel toalha, e os "pellets" foram então deixados para secar à temperatura ambiente, por cerca de 20 minutos. Após isto os ácidos nucléicos foram ressuspendidos em $50 \mu \mathrm{L}$ de TE (10 $\mathrm{mM}$ de Tris- $\mathrm{HCl}$ pH 8,0 e 1,0 mM de EDTA) contendo RNAse (10 $\mu \mathrm{g}$ de RNAse por $\mathrm{mL}$ de TE) e os tubos foram então colocados em estufa, à $37^{\circ} \mathrm{C}$, por três horas, para digestão do RNA presente nas amostras. As amostras de DNA foram conservadas em geladeira e quantificadas com fluorímetro modelo DyNA Quant 200 (Hoeffer Pharmacia Biotech, San Francisco, CA). Para as reações de PCR (Reação da Polimerase em Cadeia) foram utilizadas soluções de trabalho com diluições das amostras de DNA em TE para a concentração de $10 \mathrm{ng} / \mu \mathrm{L}$. 
Os marcadores microssatélites utilizados foram os seguintes, por serem citados na literatura como ligados a QRLs da PVR:

a) Grupo de ligação C2: Satt371 (lqbal et al., 2001);

a) Grupo de ligação G: Satt038 (Bell-Johnson et al., 1998; Prabhu et al., 1999), Satt163 (BellJohnson et al., 1998; Njiti et al., 2002), Satt309 (Bell-Johnson et al., 1998; Meksem et al., 1999a; lqbal et al., 2001) e Satt570 (lqbal et al., 2001);

c) Grupo de ligação I: Satt354 (Iqbal et al., 2001).

A sua sequência foi obtida junto ao banco de dados "Soybase" (http://129.186.26.94/ ssr.html) e a síntese dos "primers" ("forward" e "reverse") foi efetuada pela empresa Life Technologies do Brasil (Gibco BRL). As sequências dos "primers" utilizados são as seguintes:

a) Satt038

Forward: GGG AAT CTT TTT TTC TTT CTA TTA AGT T

Reverse: GGG CAT TGA AAT GGT TTT AGT CA

b) Satt163

Forward: AAT AGC ACG AGA AAA GGA GAG A

Reverse: GTG TAT GTG AAG GGG AAA AAC TA

c) Satt309

Forward: GCG CCT TCA AAT TGG CGT CTT

Reverse: GCG CCT TAA ATA AAA CCC GAA ACT

d) Satt354

Forward: GCG AAA ATG GAC ACC AAA AGT AGT TA

Reverse: GCG ATG CAC ATC AAT TAG AAT ATA CAA

e) Satt371

Forward: TGC AAA CTA ACT GGA TTC ACT CA

Reverse: GAG ATC CCG AAA TTT TAG TGT AAC A

f) Satt570

Forward: CTC ATG TGG TCC TAC CCA GAC TCA

Reverse: CGC TAT CCC TTT GTA TTT TCT TTT GC

As reações de PCR dos marcadores microssatélites foram realizadas em termociclador PTC-100 (MJ Research, Watertown, MA), com um volume total de $15 \mu \mathrm{L}$, o qual conteve $10 \mathrm{mM}$ de Tris- $\mathrm{HCl}\left(\mathrm{pH}\right.$ 8,3), $50 \mathrm{mM}$ de $\mathrm{KCl}, 3 \mathrm{mM}$ de $\mathrm{MgCl}_{2}, 0,25 \mathrm{mM}$ de cada um dos desoxinucleotídeos (dATP, dTTP, dGTP e dCTP), 0,2 $\mu \mathrm{M}$ de cada "primer" ("forward" e "reverse"), uma unidade da enzima Taq DNA polimerase e $30 \mathrm{ng}$ de DNA ( $3 \mu \mathrm{L})$. O programa de amplificação utilizado foi constituído de uma etapa inicial de quatro minutos a $94^{\circ} \mathrm{C}$, seguida de 35 ciclos de um minuto a $94^{\circ} \mathrm{C}$, um minuto a $50^{\circ} \mathrm{C}$ e dois minutos a $72^{\circ} \mathrm{C}$, e uma etapa final de sete minutos a $72^{\circ} \mathrm{C}$. 
Os fragmentos amplificados foram separados em gel de agarose ultra pura (Life Technologies do Brasil-Gibco BRL) a $3 \%$, contendo $0,4 \mu \mathrm{g} / \mathrm{mL}$ de brometo de etídio e tampão TBE 0,5 X (45 mM de Tris Base, $45 \mathrm{mM}$ de Ácido Bórico e $1 \mathrm{mM}$ de EDTA). Antes do carregamento do gel cada amostra recebeu $3 \mu \mathrm{L}$ de corante composto de azul de bromofenol $(0,25 \% \mathrm{v} / \mathrm{v})$ e sacarose $(40 \% \mathrm{v} / \mathrm{v})$, diluídos em água milli-Q. A eletroforese foi efetuada entre 70 e 80 volts, durante duas a três horas, conforme necessário para cada marcador. Como referência de peso molecular foram empregados $3 \mu \mathrm{L}$ de DNA "step ladder" 50 pb (Promega).

Além dos marcadores microssatélites também se utilizou o marcador RAPD OPE02 ${ }_{1000}$ (Operon), cuja sequência é 5'-GGT GCG GGA A3', o qual também é ligado a um dos QRLs responsáveis pela resistência a PVR no grupo de ligação G (Chang et al., 1996; Torto et al., 1996; lqbal et al., 2001). Embora este marcador foi citado como OE02 ${ }_{1000}$, segundo a nomenclatura de Michelmore \& al. (1991) a sua denominação mais correta seria OPE02 ${ }_{1000}$, como será feito de agora em diante. A reação de PCR deste marcador foi realizada em termociclador PTC-100 (MJ Research, Watertown, MA), com um volume total de $15 \mu \mathrm{L}$, o qual conteve $10 \mathrm{mM}$ de Tris- $\mathrm{HCl}\left(\mathrm{pH}\right.$ 8,3), $50 \mathrm{mM}$ de $\mathrm{KCl}, 2,4 \mathrm{mM}$ de $\mathrm{MgCl}_{2}, 0,1 \mathrm{mM}$ de cada um dos desoxinucleotídeos (dATP, dTTP, dGTP e dCTP), 0,2 $\mu \mathrm{M}$ do "primer" OPE02 ${ }_{1000}$, uma unidade da enzima Taq DNA polimerase e $30 \mathrm{ng}$ de DNA ( $3 \mu \mathrm{L})$. O programa de amplificação utilizado foi constituído de 45 ciclos de um minuto a $94^{\circ} \mathrm{C}$, um minuto a $36^{\circ} \mathrm{C}$ e dois minutos a $72^{\circ} \mathrm{C}$, e uma etapa final de sete minutos a $72^{\circ} \mathrm{C}$, segundo Hnetkovsky et al. (1996). Os fragmentos amplificados foram separados em gel de agarose ultra pura (Life Technologies do Brasil-Gibco BRL) a 1,4\%, contendo $0,4 \mu \mathrm{g} / \mathrm{mL}$ de brometo de etídio e tampão TBE 0,5 X (45 mM de Tris Base, $45 \mathrm{mM}$ de Ácido Bórico e $1 \mathrm{mM}$ de EDTA). Antes do carregamento do gel cada amostra recebeu $3 \mu \mathrm{L}$ de corante composto de azul de bromofenol $(0,25 \% \mathrm{v} / \mathrm{v})$ e sacarose $(40 \% \mathrm{v} / \mathrm{v})$, diluídos em água milli-Q. A eletroforese foi efetuada a 60 volts, durante quatro a cinco horas.

A observação dos fragmentos amplificados de DNA foi efetuada em transiluminador de luz ultravioleta, os quais foram registrados com câmara fotográfica do aparelho Image Master VDS (Pharmacia Biotech, San Francisco, CA), cuja imagem também foi capturada por computador.

Os fragmentos microssatélites amplificados também foram separados em gel de poliacrilamida a $6 \%$ (20:1 de acrilamida:biscrilamida, 7,5 M de uréia e TBE $1 \mathrm{X}$ ). Antes do carregamento do gel, cada tubo contendo $15 \mu \mathrm{L}$ com o DNA amplificado recebeu $8 \mu \mathrm{L}$ de tampão de corrida de formamida ( $10 \mathrm{~mL}$ de formamida, $200 \mu \mathrm{L}$ de EDTA 0,5 M pH 8,0, $10 \mathrm{mg}$ de azul de bromofenol e $10 \mathrm{mg}$ de cianol xileno) e passou por uma denaturação de cinco minutos a $94^{\circ} \mathrm{C}$. Após a montagem da cuba de gel de sequenciamento vertical contendo TBE $1 \mathrm{X}$, o gel foi aquecido (uma hora a $80 \mathrm{~W}$ ), antes de receber as amostras. Cada poço do gel recebeu $11 \mu \mathrm{L}$ de amostra. A eletroforese foi efetuada em voltagem constante de $60 \mathrm{~W}$, por 
cerca de quatro horas ou até o tampão formamida atingir cerca de dois terços do comprimento do gel. A coloração do gel de poliacrilamida foi efetuada com prata. Após se retirar o gel da moldura este passou pelas seguintes etapas (soluções): a) Fixação (etanol 10\% e ácido acético glacial 1\%) por dez minutos; b) Lavagem por um minuto; c) Pré-tratamento (ácido nítrico 1,5\%) por dois minutos e quarenta segundos; d) Lavagem por um minuto; e) Impregnação (nitrato de prata $0,2 \%$ ) por 20 minutos; f) Lavagem por 30 segundos (duas vezes); g) Revelação (30 g/L de carbonato de sódio e $0,54 \mathrm{~mL} / \mathrm{L}$ de formaldeído) por cerca de cinco a dez minutos (divididos em duas etapas: até o início do aparecimento das bandas e até a coloração final, em bandejas separadas); h) Bloqueio (ácido acético glacial 5\%); e i) Lavagem por um minuto. Após isto o gel foi secado a temperatura ambiente por 24 horas antes de ser analisado. Todas as etapas foram feitas sob lenta agitação, em mesa agitadora, utilizando-se 2,0 L de cada solução, com exceção da etapa de revelação, na qual a bandeja foi agitada manualmente e contendo apenas 1,0 $\mathrm{L}$ de solução de cada vez. Todas as soluções foram mantidas resfriadas em geladeira até a sua utilização, com exceção da solução de revelação, mantida em congelador por duas a três horas, e da solução de impregnação, mantida a temperatura ambiente.

Durante a etapa de discriminação dos marcadores polimórficos, além das cultivares MG/BR-46 (Conquista) e FT-Estrela, também foram genotipadas todas as cultivares de interesse para o presente trabalho, sendo estas as seguintes: Forrest, IAC-4, FT-Cristalina, Ripley, Essex, OCEPAR-9 (SS-1), IAC-8 e IAC-8-2. Destas, as quatro primeiras também participaram dos cruzamentos dialélicos, 'Essex' serviu como testemunha de suscetibilidade e, as três últimas, de outros trabalhos.

A análise de ligação entre genes de resistência e marcadores moleculares foi efetuada pela análise de co-segregação utilizando-se 126 plantas $F_{2}$ do cruzamento 'Conquista' $x$ 'Estrela', do experimento conduzido no telado (TE-JUL01). Cada planta foi genotipada com os marcadores polimórficos (Satt163 e Satt354) e esta informação foi utilizada para classificar as plantas em uma das três classes genotípicas esperadas em uma população $F_{2}$.

A análise de ligação consistiu na comparação estatística entre as classes genotípicas para a variável severidade dos sintomas foliares (escala de notas de 1 a 5), cujos valores foram transformados para $\sqrt{\mathrm{x}+0,5}$. Realizou-se a análise de variância para cada loco marcador segundo o delineamento inteiramente casualizado (análise de marcas individuais). Também se fez a decomposição dos graus de liberdade da fonte de variação genótipos nos seguintes contrastes ortogonais: $Y_{A}=\hat{I}_{M M}-\hat{I}_{m m}$ e $Y_{D}=2 \hat{i}_{M m}-\left(\hat{i}_{M M}+\hat{I}_{m m}\right)$, respectivamente, para testar as estimativas do efeito aditivo e de dominância de cada loco marcador. Testes de Tukey também foram realizados para comparações das médias das classes genotípicas de cada loco marcador. 
O valor do coeficiente de determinação $\left(r^{2}\right)$ do modelo da análise de variância foi utilizado para estimar a porcentagem de variação fenotípica explicada por cada marcador.

A proporção da variação fenotípica da resistência das plantas a PVR, explicada por cada marcador foi um dos indicativos utilizados para avaliar a eficiência da seleção com base nos marcadores moleculares. Esta eficiência, em termos de porcentagem, também foi calculada por meio de tabelas de contingência (Mudge et al., 1997), comparando-se o número de indivíduos classificados como resistentes (nota máxima de severidade dos sintomas foliares da PVR igual a 2) ou suscetíveis, com base na seleção pelos marcadores moleculares ou pela seleção fenotípica. Testes de $X^{2}$ foram efetuados para se verificar distorções da segregação 3:1 para cada loco marcador. 


\section{RESULTADOS E DISCUSSÃO}

\subsection{Estudo da herança da resistência da soja a PVR}

\subsubsection{Bloco de cruzamentos}

Segundo o acompanhamento efetuado no bloco de cruzamentos (safra 1999/2000), foram realizados 1.162 hibridações, obtendo-se um sucesso (flores cruzadas que desenvolveram sementes) médio de $26,2 \%$. Também se observou que, nas hibridações efetuadas no final da manhã e início da tarde, durante todo o mês de dezembro de 1999, a taxa de sucesso foi de $17,9 \%$, variando de 4,3 a $33,3 \%$ entre as 15 combinações das cultivares utilizadas (dialelo 6x6). Posteriormente, até a terceira semana de fevereiro de 2000, as hibridações foram realizadas somente à tarde (após às 16 horas do horário de verão), quando então se obteve uma taxa de sucesso média de $50 \%$, variando de 25 a $80 \%$. Boa parte deste aumento na taxa de sucesso, provavelmente, foi devida à ocorrência de condições climáticas mais favoráveis, como maior umidade relativa do ar, a partir de janeiro. Porém, com certeza, o horário de final da tarde foi mais favorável para o sucesso das hibridações, principalmente, pela menor exposição das flores, utilizadas como receptoras de pólen, às condições de temperatura e umidade relativa do ar desfavoráveis logo após efetuada a hibridação, visto estar mais próximo do período noturno.

Também se efetuou a contagem do número de sementes nas vagens oriundas das hibridações, observando-se maior porcentagem de vagens com duas sementes $(62,7 \%)$, seguida de uma semente $(28,2 \%)$ e três sementes $(9,1 \%)$, obtendo-se, em média, 1,8 sementes/vagem. Os valores observados de sucesso e número médio de sementes por vagem formada em uma flor hibridizada estão dentro da faixa de valores normalmente esperados em condições tropicais. 


\subsubsection{Testes de inoculação}

No primeiro teste de inoculação não se conseguiu a reprodução dos sintomas foliares típicos da podridão vermelha das raízes da soja (PVR), constatando-se apenas a presença de lesões necróticas nas raízes e leve clorose em mosaico nas folhas mais novas, na terceira semana após a emergência. Posteriormente, estas folhas voltaram a ter aspecto normal e apenas a necrose radicular evoluiu, mas sem efeitos negativos visíveis sobre 0 desenvolvimento das plantas. Procedendo-se ao isolamento do patógeno a partir de fragmentos de raízes infectadas, o fungo obtido correspondeu exatamente àquele inoculado, cujos esporos não apresentavam coloração azulada. A análise morfológica detalhada em lupa e microscópio, confirmou tratar-se de Fusarium solani f.sp. phaseoli (FSB), conforme a descrição de Roy et al. (1989) e Roy (1997), embora o patógeno inoculado tenha sido isolado a partir de plantas com sintomas típicos da PVR, tanto nas raízes quanto na parte aérea. Segundo Roy et al. (1989) várias espécies de Fusarium foram isoladas a partir de plantas de soja com sintomas típicos da PVR, sendo as freqüências de isolamento de 76 e 51\%, respectivamente, para FSB e FSA. Isto ajuda a explicar o fato ocorrido, pois a forma causadora da PVR, ou seja, a FSA, foi isolada em menor freqüência que FSB. Além disso, embora a distinção entre as duas formas de F. solani (FSA e FSB) tenha sido descrita em 1989 (Roy et al., 1989), vários anos depois ainda existiam dúvidas a respeito da sua identificação e da doença que cada uma provocava (Roy, 1997). Assim, apenas em 1997 é que foi sugerido que FSA fosse classificada como $F$. solani f.sp. glycines, sendo a presença de esporos de coloração azulada a sua principal característica morfológica (Roy, 1997).

De qualquer forma, este primeiro teste foi útil por demonstrar que nos sacos plásticos a temperatura média do solo (a $5 \mathrm{~cm}$ de profundidade), por volta do meio-dia, no mês de maio, foi de $25,4^{\circ} \mathrm{C}$ (variando entre 15 e $37^{\circ} \mathrm{C}$ ), enquanto que nos vasos de cerâmica a média foi de $21,2^{\circ} \mathrm{C}$ (variando entre 12 e $29^{\circ} \mathrm{C}$ ). Com isto, observourse que os vasos de cerâmica foram mais adequados para a manutenção de uma temperatura do solo mais favorável ao desenvolvimento do patógeno, visto que, segundo Scherm \& Yang (1996), temperaturas do solo em torno de $15^{\circ} \mathrm{C}$ favoreceram a expressão dos sintomas radiculares e, entre 22 e $24^{\circ} \mathrm{C}$, dos sintomas foliares da PVR. Além disso, como F. solani f.sp. phaseoli é patogênico ao feijão, este teste também demonstrou a possibilidade de multiplicação deste patógeno, durante o cultivo da soja, podendo isso ser problema naquelas áreas em que também se cultiva feijão.

Assim, no segundo teste de inoculação foi utilizado o isolado SDS-5, fornecido pelo Dr. José Tadashi Yorinori, pesquisador da Embrapa Soja, Londrina-PR. Neste teste, a emergência

ocorreu aos sete dias após a semeadura e os primeiros sintomas foliares da PVR foram observados aos nove dias após a emergência das plântulas, mas apenas na cultivar IAC-4. Aos 
13 dias após a emergência, as cultivares Estrela e Ripley apresentaram os primeiros sintomas foliares, seguidas das demais cultivares, de tal forma que aos 18 dias se fez a primeira avaliação e, aos 21 dias, a segunda, cujos dados estão apresentados na Tabela 4. De maneira geral, observou-se uma grande variação na severidade dos sintomas foliares da PVR entre as plantas de um mesmo vaso, a qual tendeu a ser maior nas cultivares que se mostraram mais suscetíveis. Também se observou que a severidade média e o índice de doença dos sintomas foliares pareceram mais adequados que a porcentagem de incidência da doença para a discriminação da resistência das cultivares utilizadas. Com base nesses resultados, apesar do pequeno número de plantas avaliadas em cada cultivar, confirmou-se, preliminarmente, a maior suscetibilidade das cultivares Cristalina e Estrela e a maior resistência de Forrest e Conquista, enquanto que Ripley foi a mais suscetível, ao contrário do esperado. Isto porque, em vários trabalhos conduzidos nos Estados Unidos, foi citado que a cultivar Ripley era resistente a PVR em experimentos com inoculação artificial (Stephens et al., 1993a; Heavner et al., 1996; Ringler \& Nickell, 1996; Hartman et al., 1997; Njiti et al., 2001) e também a campo (Njiti et al., 1997a; Luo et al., 1999). Por outro lado, Klingelfuss et al. (2001a), também utilizando o isolado SDS-5, classificaram a cultivar Ripley como moderadamente suscetível a PVR, embora em um dos experimentos o seu nível de resistência não tenha diferido de 'Conquista', classificada como moderadamente resistente. Gray \& Achenbach (1996), também observaram comportamento instável da cultivar Ripley sob inoculação artificial. Assim, três fatores principais poderiam estar contribuindo para a cultivar Ripley ter apresentado comportamento suscetível: a) Maior agressividade do isolado SDS-5 em relação aos isolados dos EUA; b) Maior pressão de inóculo; c) Condições ambientais mais favoráveis ao desenvolvimento do patógeno e/ou para a expressão dos sintomas foliares da PVR. Desta forma, a cultivar Ripley e seus cruzamentos não foram incluídos nas avaliações com a geração $F_{2}$, permitindo um aumento de $50 \%$ (de 100 para 150) no número de plantas $F_{2}$ a serem avaliadas em cada cruzamento, num mesmo experimento. Além da cultivar Ripley, IAC-4 também teve comportamento inesperado, já que havia relatos dela ser altamente resistente a PVR (Yorinori et al., 1993; Vello ${ }^{2}$ ). Isto fez com que ela passasse a ser considerada como moderadamente resistente a PVR, conforme resultados já observados por Yorinori \& Nomura (1994).

No terceiro teste de inoculação não se conseguiu a reprodução dos sintomas foliares da PVR o que, a princípio, foi atribuído à época em que foi instalado este experimento (31/08), quando ocorrem temperaturas bastante elevadas e baixa umidade relativa do ar, por coincidir com o final do inverno e da época "da seca". Posteriormente, pela comparação do aspecto do fungo durante o crescimento nos grãos de sorgo (crescimento intenso de micélio branco e

${ }^{2}$ VELLO, N. A. (Universidade de São Paulo. Escola Superior de Agricultura "Luiz de Queiroz", Departamento de Genética, Piracicaba). Comunicação pessoal, 1999. 
aspecto rosado em vez de azulado) e pela pequena quantidade de macroconídios observada, concluiu-se que a quantidade de esporos presente foi insuficiente para permitir uma boa inoculação do patógeno.

No quarto teste de inoculação efetuado, instalado no telado em pleno inverno (08/07), a emergência demorou 15 dias, sendo que em algumas covas nenhuma plântula emergiu, provavelmente, porque as sementes foram colocadas a $5 \mathrm{~cm}$ de profundidade. De maneira geral, observou-se diferença significativa entre os dois métodos de inoculação para todas as características avaliadas nas quatro épocas, sendo que a utilização de cinco grãos de sorgo sempre causou sintomas foliares da PVR mais intensos do que um grão de soja (Tabelas 5 e 6). Houve interação cultivares $x$ métodos de inoculação significativa apenas para a severidade dos sintomas foliares, aos 26 dias após a emergência (Tabela 5), e para a porcentagem de incidência, aos 33 dias após a emergência (Tabela 6). No primeiro caso, as cultivares apresentaram diferenças significativas entre si para a severidade apenas quando se utilizaram grãos de sorgo para a inoculação (Tabela 5), mas os resultados não seguiram o esperado, pois as cultivares Cristalina e Estrela estiveram entre as mais resistentes, não diferindo de 'Forrest', e a cultivar resistente Conquista esteve entre as mais suscetíveis, não diferindo de 'IAC-4', a qual foi a mais suscetível, embora esta também não tenha diferido de 'Forrest'; quando se comparou os dois métodos de inoculação para cada cultivar, houve diferenças significativas entre estes apenas para 'Conquista', 'IAC-4' e 'SS-1', sendo que os grãos de sorgo causaram maior severidade dos sintomas foliares que os grãos de soja. No segundo caso, as cultivares apresentaram diferenças significativas entre si para a incidência apenas quando foram utilizados grãos de soja para a inoculação (Tabela 6), sendo que 'SS-1' foi a mais resistente, diferindo de 'Forrest' e de 'Estrela'. Esta última foi a mais suscetível, mas não diferiu da cultivar resistente 'Forrest'; quando se comparou o método de inoculação dentro de cada cultivar, diferenças significativas foram observadas nas cultivares Conquista, Cristalina, IAC-4, IAC-8-2 e SS-1, sendo a maior incidência obtida com os grãos de sorgo. De maneira geral, embora não tenham sido observadas diferenças significativas entre as cultivares, a não ser nos casos comentados, houve tendência da avaliação aos 40 ou 47 dias após a emergência proporcionar discriminação razoável entre os genótipos, sendo que a severidade dos sintomas foliares pareceu ser a variável mais adequada. Além disso, pelo comportamento das cultivares Estrela e Essex, comprovadamente suscetíveis, e Forrest e Conquista, consideradas resistentes, parece que a utilização de cinco grãos de sorgo colonizados com o patógeno e colocados em contato direto com as sementes de soja, embora não tenha sido o suficiente para provocar uma severa manifestação dos sintomas foliares da PVR (notas próximas do valor máximo 5) nas cultivares suscetíveis, talvez tenha causado sintomas em demasia nas cultivares resistentes, principalmente em 'Conquista'. O mesmo comportamento foi observado com a cultivar SS-1, 
que se comportou como resistente em teste anterior (Tabela 4). Isto sugere que, para a intensidade de inóculo utilizada, talvez fosse mais adequado utilizar apenas três grãos de sorgo em contato direto com as sementes, ou os cinco grãos colocados um pouco abaixo (cerca de $1 \mathrm{~cm}$ ) das sementes de soja, evitando-se o seu contato direto com o inóculo. Além disso, para prevenir a diminuição do número de plântulas emergidas, pelo aumento do tempo para a emergência devido à baixa temperatura do solo, seria necessário colocar as sementes em covas com menor profundidade, talvez $3 \mathrm{~cm}$ no máximo.

\subsubsection{Análises de resíduos}

Segundo a análise de resíduos, realizada para se testar 0 atendimento das pressuposições da análise de variância em termos de normalidade dos resíduos e homogeneidade de variâncias de tratamentos, nos experimentos com a geração $F_{2}$, não foi possível se proceder à análise de variância ao nível de plantas individuais, principal mente porque os resíduos não apresentaram distribuição normal. Desta forma, as análises de variância foram realizadas com as médias de parcelas (vasos com cinco plantas), não sendo possível estimar as herdabilidades com base em plantas individuais. Além disso, para algumas variáveis, a normalidade dos resíduos só foi atingida com a transformação dos dados, principalmente, nos experimentos de 2001 (Apêndice 1). No experimento de 2002 (CV-JUL02), o índice de doença com base no aspecto geral da planta e a incidência apresentaram problemas. Com relação ao índice de doença, como não se conseguiu melhorar a homogeneidade das variâncias mesmo com a transformação de arco seno, pois, apesar de ser uma variável adimensional, a sua variação é entre 0 e 100, as análises foram realizadas mesmo assim, visto que os testes foram aproximados, já que o experimento foi desbalanceado.

Para o caso específico da variável incidência da doença (em porcentagem), mesmo com a transformação dos dados, os resíduos não apresentaram distribuição normal e nem houve homogeneidade de variâncias, de forma que os resultados desta variável foram apresentados apenas em termos de médias, sem se proceder à análise de variância. De qualquer forma, as evidências indicaram que, de maneira geral, não seriam encontradas diferenças significativas entre as médias de tratamentos caso a análise de variância para a incidência da doença fosse realizada. Isto indicou que, ao contrário do observado em experimentos realizados a campo, sob inoculação natural (Hershman et al., 1990; Chang et al., 1996 e 1997; Hnetkovsky et al., 1996; Njiti et al., 1998b e 2002; lqbal et al., 2001), a qual, normalmente, proporciona baixos níveis de severidade dos sintomas foliares, sob condições de inoculação artificial, a porcentagem de incidência da doença não seria adequada para a 
discriminação do nível de resistência de diferentes genótipos de soja a PVR. No entanto, Klingelfuss et al. (2001a), utilizando inoculação artificial pelo método do palito de dente, concluíram que a incidência da doença, denominada como a porcentagem de plantas afetadas pela PVR, foi o melhor critério de avaliação para a distinção da reação de genótipos, seguido pela escala de notas de 1 a 5 .

\subsubsection{Análises de variância com a geração $F_{2}$}

Os resultados das análises de variância para todos os caracteres analisados, assim como das análises de variância dos contrastes ortogonais estabelecidos, estão apresentados nas Tabelas 7 a 12.

Com raras exceções, os coeficientes de variação foram sempre elevados na maioria dos experimentos, situando-se entre 20 e $30 \%$ ou, até mais, em alguns casos, o que não impediu a detecção de diferenças altamente significativas entre os tratamentos para a maioria dos caracteres analisados. Em todos os experimentos, o índice de doença foi o caráter que sempre apresentou maior coeficiente de variação (Tabelas 7, 9 e 11). Como ainda não se dispõe de um método de inoculação capaz de promover a infecção uniforme das plantas inoculadas, aliado ao fato da intensidade de manifestação dos sintomas foliares da PVR ser altamente dependente das condições ambientais, principalmente, intensidade de inóculo, temperatura e umidade do solo, em termos gerais, esta menor precisão experimental já era esperada. Hartman et al. (1997), também utilizando inoculação artificial com grãos de sorgo colonizados com o patógeno, obtiveram coeficientes de variação entre 18 e $20 \%$. Utilizando o método do palito de dente, Gásperi (2000) obteve $C V=20 \%$, enquanto que Klingelfuss et al. (2001a) obtiveram CV's entre 5,7 e $\mathfrak{B}, 8 \%$, dependendo da forma de avaliação dos sintomas foliares e do experimento considerado (duas épocas diferentes). Segundo estes últimos autores, a utilização da escala de notas de severidade de 1 a 5 proporcionou CV de 15,9\%.

O efeito de blocos foi significativo na maioria dos casos (Tabelas 7 e 9), demonstrando o aumento da precisão experimental pela sua utilização, principalmente, em termos de uniformização da temperatura do solo dos vasos dentro das repetições, pois estas variaram bastante entre os bocos (vide apêndices), por causa da sua diferente exposição ao sol, apesar de serem ambientes protegidos. Já no experimento CV-JUL02, conduzido no delineamento inteiramente casualizado, foram tomadas algumas providências para uniformizar a temperatura do solo dos vasos, como por exemplo a colocação de placas de isopor na lateral das bancadas para se evitar a exposição direta dos vasos ao sol, diminuindo o aquecimento do solo destes vasos, além da abertura da cobertura de "aluminet" durante o período da manhã, a fim de elevar 
a temperatura do solo dos vasos situados nas bancadas mais sombreadas e de se proceder à irrigação, preferencialmente, no período da manhã.

Em nenhum dos casos se observou heterogeneidade entre os resíduos específicos, de forma que sempre foi utilizado o resíduo geral para os testes de significância nas análises de variância (Tabelas 7, 9 e 11).

Apenas para o comprimento das lesões nas raízes não foram detectadas diferenças significativas entre os 15 genótipos avaliados (Tabela 7). Assim, foram observadas diferenças significativas entre os genitores para a maioria dos caracteres analisados, com exceção da severidade e comprimento das lesões nas raízes, no experimento TE-JUL01 (Tabela 7), e do índice de doença dos sintomas foliares (IDF e IDP), no experimento CV-JUL02 (Tabela 11). Entre os cruzamentos $F_{2}$ somente não se observaram diferenças significativas para 0 comprimento das lesões nas raízes (Tabela 7 ). O contraste "genitores vs. cruzamentos $F_{2}$ " indicou diferenças entre o grupo das cultivares e o grupo dos cruzamentos somente no experimento CV-JUL02 (Tabela 11), indicando a presença de efeito de heterose média nos caracteres analisados neste experimento, com exceção da severidade dos sintomas foliares desconsiderando-se as plantas com nota 1 (SP1). Os demais contrastes realizados, normalmente, indicaram diferenças significativas nos caracteres severidade e índice de doença dos sintomas foliares para ('Forrest' + 'Conquista') vs. demais genitores (Tabelas 8, 10 e 12), ('Conquista' $x$ 'Forrest') vs. demais cruzamentos (Tabelas 8 e 12) e cruzamentos "suscetíveis" vs. cruzamentos "resistentes" (Tabelas 8,10 e 12). Além destes, também cumpre comentar a significância dos contrastes ('Cristalina' + 'Estrela') vs. 'IAC-4' e ('Conquista' x 'Cristalina') vs. ('Conquista' x 'Estrela'), no experimento CV-SET01 (Tabela 10), e ('Conquista' x 'Cristalina' + 'Conquista' $x$ 'Estrela') vs. ('Conquista' x 'IAC-4'), ('Forrest' x 'Cristalina' + 'Forrest' x 'Estrela') vs. ('Forrest' $x$ 'IAC-4') e cruzamentos envolvendo 'Conquista' vs. cruzamentos envolvendo 'Forrest' no experimento CV-JUL02 (Tabela 12).

Pela significância destes contrastes confirmou-se a maior resistência de 'Forrest' e 'Conquista', assim como a maior suscetibilidade de 'Cristalina' e 'Estrela', e o comportamento instável da cultivar IAC-4. Além disso, apesar da desuniformidade observada na manifestação dos sintomas foliares da PVR dentro dos tratamentos e pelo fato dos genitores não serem muito divergentes, já que não se dispunha de nenhum genótipo altamente resistente ou imune a PVR, o método dos grãos de sorgo ainda permitiu uma boa discriminação dos tratamentos com relação àresistência a PVR.

Estes resultados demonstraram as variações existentes entre os tratamentos, as quais, apesar de serem de pequena magnitude, ainda assim foram significativas, permitindo a realização da análise dialélica posterior. Desta forma, com base nestes resultados, não se procedeu à análise dialélica apenas para os caracteres severidade e comprimento das lesões 
nas raízes, cuja avaliação foi realizada somente nas plantas desbastadas no experimento TEJUL01. Com relação a estes dois caracteres, foi possível a avaliação de 1.257 plantas, das 1.750 covas semeadas, pois nem todas as sementes germinaram. Uma grande dificuldade enfrentada, além de ser um trabalho moroso e difícil, foi o grande número de raízes arrebentadas. Apesar de se ter utilizado um solo com bastante matéria orgânica (proveniente de compostagem orgânica) e de se encharcar o solo antes de se proceder àavaliação, 39,7\% das plantas desbastadas ainda tiveram parte da raiz rompida, prejudicando, em maior ou menor grau, as avaliações feitas nas raízes. Outra dificuldade é que, æ̀s vezes, foi difícil separar as lesões causadas pelo fungo (de coloração marrom-avermelhada), daquelas lesões (de aspecto mais enegrecido) causadas por saprófitas durante a decomposição dos grãos de sorgo que veicularam o inóculo. Assim, este tipo de avaliação, embora mais prático do que se efetuado em raízes de plantas adultas, não se mostrou adequado para a discriminação do grau de resistência dos genótipos. Além disso, dependendo da intensidade de inóculo (número de macroconídios presentes nos grãos de sorgo e número de grãos de sorgo/cova) e de outros fatores como a temperatura do solo e o período transcorrido entre a semeadura e emergência, os sintomas radiculares podem ainda não estarem visíveis durante a emergência das plântulas, conforme observado no experimento CV-JUL02.

\subsubsection{Análise dialélica de Jinks-Hayman com a geração $F_{2}$}

\subsubsection{Testes das restrições do modelo genético}

\section{a) Análises de variância de $\hat{W}_{i}-\hat{V}_{i}$}

Os resultados das análises de variância de $\hat{W}_{i}-\hat{V}_{i}$ estão apresentados na Tabela 13 , na qual também se encontram os resultados das análises de variância de $\hat{W}_{i}+\hat{V}_{i}$ para os experimentos em blocos ao acaso (TE-JUL01 e CV-SET01), nos quais se utilizou o mesmo número de repetições para todos os tratamentos.

Tanto as análises de variância de $\hat{\mathrm{W}}_{\mathrm{i}}-\hat{\mathrm{V}}_{\mathrm{i}}$ quanto de $\hat{\mathrm{W}}_{\mathrm{i}}+\hat{\mathrm{V}}_{\mathrm{i}}$ para severidade e índice de doença dos sintomas foliares da PVR, em ambos experimentos, não apresentaram efeito significativo da fonte de variação "linhas" (Tabela 13). Para a variável $\hat{W}_{i}-\hat{V}_{i}$ isto representa o atendimento das restrições impostas para a utilização do modelo genético de Jinks-Hayman. 
Esta homogeneidade de $\hat{W}_{i}-\hat{V}_{i}$ sugere que as diferenças genéticas existentes entre os tratamentos foram explicadas pelas ações gênicas aditiva ou de dominância ou, pela presença de ambas. Já para a variável $\hat{\mathrm{W}}_{\mathrm{i}}+\hat{\mathrm{V}}_{\mathrm{i}}$, a ausência de efeito significativo de "linhas" é um indício de que os efeitos de dominância, se presentes no controle da resistência a PVR, não se manifestaram em magnitude suficiente para serem significativos, sugerindo apenas a presença de efeitos gênicos aditivos no controle da resistência a PVR nestes experimentos.

Em todos os casos observou-se efeito altamente significativo de blocos (Tabela 13), de forma semelhante àquela já observada nas análises de variância anteriores (Tabelas 7 e 9). Desta forma, como a manifestação da característica de resistência foi bastante sensível às condições do ambiente, conforme indicado pelos elevados coeficientes de variação obtidos (Tabelas 7, 9 e 11), pode ter ocorrido interação elevada de $\hat{W}_{i}+\hat{V}_{i}$ com blocos, impedindo a observação de efeitos significativos de dominância pela heterogeneidade dos valores de $\hat{\mathrm{W}}_{\mathrm{i}}+\hat{\mathrm{V}}_{\mathrm{i}}$ nas análises de variância (Tabela 13), de forma semelhante à comentada por Santos (1984). Da mesma forma, a presença de elevada interação de $\hat{W}_{i}-\hat{V}_{i}$ com blocos poderia estar mascarando os resultados da análise de variância, inflacionando o resíduo e conduzindo à conclusão de homogeneidade dos valores de $\hat{\mathrm{W}}_{\mathrm{i}}-\hat{\mathrm{V}}_{\mathrm{i}}$ quando, na realidade, isto não estaria ocorrendo. Isto conduz à necessidade de se analisar o controle genético do caráter resistência por meio de outros métodos, mais precisos e, também, de se utilizar outros métodos de avaliação do atendimento das restrições do modelo genético de Jinks-Hayman, como apresentado adiante.

\section{b) Análise de regressão linear de $\hat{W}_{i}$ em função de $\hat{V}_{i}$}

Os resultados dos testes de suficiência do modelo genético aditivo-dominante de JinksHayman, com base na análise de regressão linear de $\hat{W}_{i}$ em função de $\hat{V}_{i}$, apresentados na Tabela 14, mostraram que, tanto pelo teste $t$ como pelo teste $F$, o coeficiente de regressão linear $(\hat{b})$ foi estatisticamente igual a 1,0, indicando o atendimento das restrições do modelo genético aditivo-dominante de Jinks-Hayman e ausência de epistasia no controle da resistência

a PVR para todos os caracteres analisados. O maior valor de $\hat{b}$ encontrado foi de 1,04 , para a severidade dos sintomas foliares (SF) no experimento TE-JUL01, e o menor de 0,43, para o índice de doença (IDF) no experimento CV-JUL02. Para este último caráter também se 
observou o menor valor de $r^{2}(52,0 \%)$.

Como a maioria dos valores de $\hat{F}$ foi inferior a $90 \%$ e os desvios padrões de $\hat{b}$ foram maiores que 0,1 (Tabela 14), provavelmente, a influência dos fatores ambientais ajudou a mascarar a relação entre $\hat{W}_{i}$ e $\hat{V}_{i}$ dos caracteres analisados. Por outro lado, também pode ser que as restrições do modelo foram atendidas apenas marginalmente para alguns caracteres. Segundo Jinks \& Hayman (1953), a redução da heterozigosidade na geração $F_{2}$ torna mais difícil a detecção de anomalias nos dados por este método, realizado com base nos efeitos de dominância. Assim, as causas mais prováveis de distorções poderiam ser a distribuição nãoindependente de genes entre os genitores e a presença de multialelismo, sendo pouco provável a ocorrência de epistasia. Isto porque, em trabalhos com marcadores moleculares, lqbal et al. (2001) não detectaram a presença de epistasia entre os locos marcadores ligados a QRLS (locos controladores de resistência quantitativa) que condicionaram a resistência a PVR, enquanto que Bell-Johnson et al. (1998) citaram a presença de multialelismo em locos microssatélites associados com a resistência a PVR no grupo de ligação G. A presença de multialelismo também foi constatada no presente trabalho, conforme será comentado no tópico sobre a utilização de marcadores moleculares, mas fica a dúvida se o multialelismo existente nos locos dos marcadores realmente corresponde à sua ocorrência nos locos que condicionam a resistência a PVR.

Com relação à distribuição não -independente de genes entre os genitores, é certo que esta restrição não tenha sido atendida, visto que, a linhagem M-2, genitora de 'Estrela', é irmã de 'Cristalina'. Além disso, se 'Cristalina' for resultante de cruzamento natural entre as cultivares UFV-1 e Davis, conforme citado por Spehar (1994), mas 'Davis' também é ancestral de 'Conquista'. Segundo Hayman (1954a), pela presença de distribuição correlacionada de genes entre genitores, uma conseqüência provável é a superestimação do grau médio de dominância, cuja estimativa será discutida posteriormente. Porém, ambas situações foram descobertas posteriormente æ̀s avaliações, sendo o único procedimento possível a exclusão da cultivar Cristalina das análises dialélicas. Assim, as análises de índice de doença dos sintomas foliares (IDF e IDP), no experimento CV-JUL02, foram refeitas sem o genitor 'Cristalina' pois, nestes dois casos, embora o valor de $\hat{b}$ não tenha diferido significativamente de 1,0 , os seus valores foram os menores observados, o mesmo ocorrendo com o valor de $r^{2}$ (Tabela 14), além de que, apenas para IDF e IDP é que se observou que o valor de $\hat{W}_{i}-\hat{V}_{i}$ da cultivar Cristalina era muito diferente dos demais genitores. Como conseqüência, após a exclusão de 'Cristalina', observouse uma sensível melhoria nos valores de $\hat{b}$ e de $r^{2}$ para estas duas variáveis; porém, o modelo de regressão ainda assim não foi significativo a $5 \%$ de probabilidade, mas apenas a $10 \%$, para 
os dois caracteres. Testes com outros caracteres, no experimento CV-JUL02, não demonstraram melhora nos resultados com a exclusão de 'Cristalina', sendo esta então mantida nas análises dos demais caracteres.

Quanto às demais restrições do modelo genético de Jinks-Hayman, ou seja, segregação diplóide, ausência de diferenças entre cruzamentos recíprocos e genitores homozigóticos, estas estariam sendo plenamente atendidas no presente caso.

De qualquer forma, pelos resultados obtidos, conclui-se que o modelo genético aditivodominante de Jinks-Hayman foi o suficiente para explicar o controle genético da resistência a PVR, com base na severidade e no índice de doença dos sintomas foliares, nos experimentos conduzidos e no grupo de cultivares utilizado.

\subsubsection{Análise genética}

Os resultados das análises de variância dos componentes genéticos aditivo e de dominância estão apresentados nas Tabelas 15, 16 e 17.

Nos experimentos conduzidos em 2001 (TE-JUL01 e CV-SET01) foram observados efeitos altamente significativos apenas da fonte de variação "a" para os dois caracteres analisados (Tabela 15). Isto indica que, nas condições em que foram realizados estes experimentos, apenas a ação aditiva dos genes contribuiu para a variância genética observada entre os tratamentos. Embora não tenha havido tendência de nenhum outro componente apresentar efeito significativo, provavelmente, o elevado efeito de ambiente sobre a expressão dos sintomas e a pequena magnitude das diferenças observadas entre os tratamentos, fizeram com que as diferenças entre estes fossem devidas apenas à variação genética presente entre os genitores utilizados, manifestada também no seu comportamento médio nos cruzamentos.

Por outro lado, no experimento CV-JUL02, este mesmo comportamento foi observado apenas para a severidade dos sintomas foliares da PVR desconsiderando-se as plantas com nota igual a 1 (Tabela 16). Para todos os outros caracteres analisados, além dos efeitos altamente significativos da fonte de variação "a", a fonte de variação "b" também apresentou efeito altamente significativo para o índice de doença (IDF e IDP) e significativo para severidade (SF e SP) (Tabelas 16 e 17). Isto indica que, para estes caracteres, tanto a ação gênica aditiva como de dominância contribuíram para o controle da resistência a PVR.

Entre os caracteres que exibiram dominância, o componente " $b_{1}$ " apresentou efeitos altamente significativos em todos estes, com exceção da severidade com base na nota do folíolo com sintomas mais intensos (SF), cuja significância ocorreu a $5 \%$ de probabilidade (Tabelas 16 e 17). Como por este componente se avalia a diferença entre a média dos 
genitores e a média dos cruzamentos, a sua significância indica que os desvios de dominância foram predominantemente em uma direção (Ramalho et al., 1993). Assim, conclui-se que a dominância foi no sentido de aumentar a resistência a PVR, pois a média dos cruzamentos $F_{2}$ foi sempre menor que a dos genitores (vide apêndices).

Quanto ao componente " $\mathrm{b}_{2}$ ", houve efeito significativo para o índice de doença (IDF e IDP) e tendência de significância (a até $10 \%$ de probabilidade) para a severidade dos sintomas foliares da PVR (Tabelas 16 e 17). Isto indica que há evidências de que alguns genitores apresentam maior proporção de alelos dominantes do que outros. Isto implica, então, na presença de assimetria na distribuição dos alelos (Hayman, 1954b) favoráveis e desfavoráveis nos locos em que ocorre dominância. Segundo Ramalho et al. (1993), isto evidencia heterogeneidade entre os desvios médios de dominância das progênies de meios irmãos da tabela dialélica. Em outras palavras, alguns genitores tiveram desempenho significativamente melhor do que outros quando considerada a média dos cruzamentos em que cada um participou.

Comparando-se as análises realizadas com todos os genitores e com a subtabela sem a cultivar Cristalina, os resultados foram idênticos (Tabelas 16 e 17), com exceção do nível de significância do componente " $\mathrm{b}_{2}$ " para o índice de doença (IDF), o qual foi significativo a apenas $5 \%$ de probabilidade na segunda análise (Tabela 17). Além disso, também se observou tendência do componente " $b_{3}$ " ser significativo $(P=0,081$ e 0,085 , respectivamente, para IDF e IDP)(Tabela 17). Isto indica que houve tendência de heterogeneidade dos desvios de dominância específicos para cada cruzamento, ou seja, de haver a presença de capacidade específica de combinação, embora o teste $F$, neste caso, não seja realizado de forma a testá-la corretamente (Ramalho et al., 1993).

Por outro lado, comparando-se os resultados obtidos com as notas de severidade considerando o folíolo com os sintomas mais intensos (SF e IDF) ou o aspecto geral da planta (SP e IDP), os resultados foram bastante semelhantes (Tabela 16) ou idênticos (Tabela 17), indicando que qualquer uma das avaliações poderia ser utilizada.

As estimativas dos componentes genéticos $\hat{D}, \hat{H}_{1}, \hat{H}_{2}$ e $\hat{F}$, assim como seus respectivos desvios padrões, estão apresentadas na Tabela 18.

De maneira geral, observou-se que os erros associados às estimativas dos componentes genéticos foram elevados e, em alguns casos, ultrapassaram os valores das próprias estimativas (Tabela 18). É importante salientar que o próprio Hayman (1954a) comenta que, como os desvios padrões de cada estimativa são calculados com base na variância de $\hat{\mathrm{W}}_{\mathrm{i}}-\hat{\mathrm{V}}_{\mathrm{i}}$, os seus valores não são muito precisos, sendo mais adequado obtê-los a partir das diferenças entre as estimativas de cada componente, em cada repetição, quando o experimento 
apresentar repetições. Assim, o erro de cada estimativa dos componentes genéticos corresponderia ao desvio padrão das estimativas obtidas por repetição, em torno de sua média, como utilizado por Santos (1984), a partir das sugestões de Nelder (1953). Segundo Crumpacker \& Allard (1962) esta seria a maneira mais adequada de estimar os desvios padrões dos componentes genéticos. Porém, como no caso dos experimentos em blocos ao acaso (TEJUL01 e CV-SET01), dentro de cada bloco tinha-se mais de uma parcela de cada tratamento e, ainda, em número diferente para genitores e cruzamentos $F_{2}$, optou-se pela forma mais simplificada, conforme sugerido por Hayman (1954a), apesar de não ser a mais precisa. Situação semelhante também ocorreu no experimento de 2002 (CV-JUL02), quando foi utilizado número diferente de repetições para os genitores e os cruzamentos $F_{2}$, seguindo-se 0 delineamento inteiramente casualizado. No entanto, cuidado foi tomado para se calcular da maneira mais correta possível o desvio padrão de cada estimativa, pois na literatura foram encontrados trabalhos utilizando dados da geração $F_{2}$ e os coeficientes de Ferreira (1985), específicos para a geração $F_{1}$; ou então, para testar a significância da estimativa de cada componente, dividindo o seu valor pelo seu respectivo desvio padrão e, se o resultado for superior a 1,96, considerá-lo significativo a $5 \%$ de probabilidade, conforme comentado especificamente no exemplo com oito genitores, fornecido por Singh \& Chaudhary (1979, p.115), e sugerido para qualquer número de genitores por Cruz \& Regazzi (1997, p.201).

Como os desvios padrões dos componentes genéticos foram elevados, a significância dos efeitos destes componentes, para cada caráter analisado (Tabela 18), nem sempre acompanhou os resultados das análises de variância (Tabelas 15, 16 e17), os quais são considerados mais precisos. Assim, é mais seguro tirar conclusões juntamente com os resultados das análises de variância comentadas anteriormente (Tabelas 15, 16 e 17). A principal discordância observada foi a ausência de efeito significativo do componente genético $\hat{D}$, o qual representa a variância devida aos efeitos gênicos aditivos, sendo estatisticamente igual a zero no experimento CV-JUL02, com exceção do caráter SP1 (Tabela 18), ao contrário do observado para a fonte de variação "a" (efeitos gênicos aditivos) nas análises de variância (Tabelas 15, 16 e 17). Os componentes $\hat{H}_{1}$ e $\hat{H}_{2}$, mesmo negativos, foram significativamente diferentes de zero no experimento TE-JUL01, o que também discordou da análise de variância, pois a fonte de variação "b" (efeitos gênicos de dominância) não foi significativa (Tabela 15). Isto pode ter ocorrido pela falta de precisão dos testes de significância dos componentes genéticos, conforme já comentado, podendo-se considerá-los iguais a zero nestes casos, por terem sido negativos e, talvez, também pela sua pequena magnitude. De fato, as análises de variância, cujos resultados são mais precisos, não demonstraram a presença de efeitos de dominância ("b") significativos para os caracteres em que foram obtidos valores negativos para 
os componentes $\hat{H}_{1}$ e $\hat{H}_{2}$ (Tabelas 15 e 16), ocorrendo o mesmo na análise de variância de $\hat{W}_{\mathrm{i}}+\hat{\mathrm{V}}_{\mathrm{i}}$ realizada anteriormente (Tabela 13). Estimativas negativas de $\hat{H}_{1}$ e $\hat{H}_{2}$ æ̀ vezes ocorrem, conforme encontrado em alguns trabalhos (Jones et al., 1972; Freire Filho, 1988; Xu \& Shen, 1991) e não seriam devidas a causas genéticas, pois como são componentes quadráticos, não poderiam ser negativos e significativos (Hill et al., 2001). Conforme se observa pelas expressões de cálculo dos componentes $\hat{H}_{1}$ e $\hat{H}_{2}$, provavelmente, a ocorrência de estimativas negativas seja devida à pequena magnitude dos valores das variâncias estimadas $\left(\hat{V}_{g}\right.$ e/ou $\left.\hat{V}_{\mathrm{i}}\right)$, pelas pequenas diferenças obtidas entre as médias de tratamentos, e/ou à ocorrência de elevados erros experimentais, representados pelos quadrados médios dos resíduos de genitores e cruzamentos $F_{2}$, respectivamente $E_{0}$ e $E_{2}$.

Desta forma, observou-se que a variância devida aos efeitos gênicos aditivos ("a" ou D) foi a principal responsável para explicar as diferenças entre os tratamentos, com base nos sintomas foliares da PVR, tanto para a severidade (SF) quanto para o índice de doença (IDF), nos experimentos TE-JUL01 e CV-SET01 (Tabelas 13, 15 e 18). No entanto, no experimento CV-JUL02, observou-se que as diferenças entre os tratamentos foram explicadas pelos efeitos gênicos aditivos ("a" ou D̂) e de dominância ("b" ou $\hat{H}_{1}$ ), com exceção da severidade dos sintomas foliares desconsiderando as plantas com nota 1 (SP1), cujas diferenças foram explicadas apenas pelos efeitos gênicos aditivos (Tabelas 16, 17 e 18). Em 2002, também se observou que os efeitos gênicos de dominância foram mais acentuados para 0 índice de doença (IDF e IDP) do que para a severidade (SF e SP) dos sintomas foliares, visto que, nas análises de variância os efeitos da fonte de variação "b" foram altamente significativos $(P<0,01)$ apenas para os índices de doença calculados (Tabelas 16 e 17); por outro lado, apenas para a severidade (SF e SP) as estimativas do componente genético D foram superiores ao seu respectivo desvio padrão, embora não diferiram significativamente de zero (Tabela 18).

Com relação æ̀ estimativas do componen te genético $\hat{F}$, na maioria dos casos estas foram pouco superiores que os seus desvios padrões e negativas, sendo positivas apenas para - experimento CV-SET01 e para a severidade dos sintomas foliares desconsiderando as plantas com nota 1 (SP1) no experimento CV-JUL02 (Tabela 18). Assim, embora nenhuma estimativa do componente genético $\hat{F}$ tenha sido significativamente diferente de zero, com exceção da severidade dos sintomas foliares (SF) no experimento TE-JUL01, esta maior freqüência de valores negativos pode ser um indicativo da predominância de alelos recessivos no grupo dos genitores o que, de certa forma, é comprovado pelo nível de resistência destes e também é mais um indicativo de que a resistência a PVR, no grupo de cultivares em estudo, é 
controlada por genes dominantes. Como a fonte de variação " $\mathrm{b}_{2}$ " foi significativa para o índice de doença (IDF e IDP) dos sintomas foliares da PVR (Tabelas 16 e 17), isto indica diferenças na proporção de alelos dominantes entre os genitores, podendo também ser um indicativo de que as cultivares tidas como resistentes (Forrest e Conquista) apresentam maior concentração de alelos dominantes que as demais.

As estimativas dos parâmetros genéticos, apresentadas na Tabela 19, ajudam a reforçar certos resultados já comentados anteriormente, embora nem todos os parâmetros puderam ser calculados para todos os caracteres analisados, pela ocorrência de algumas estimativas negativas dos componentes genéticos $\hat{H}_{1}$ e $\hat{H}_{2}$, principalmente, nos experimentos TE-JUL01 e CV-SET01 (Tabela 18). Por outro lado, pelas análises de variância de $\hat{\mathrm{W}}_{\mathrm{i}}+\hat{\mathrm{V}}_{\mathrm{i}}$ (Tabela 13) e das fontes de variação "a" e "b" (Tabela 15), e pelas estimativas dos componentes genéticos (Tabela 18), houve evidências de apenas efeitos gênicos aditivos nos experimentos de 2001 (TE-JUL01 e CV-SET01); todavia, pela análise gráfica do grau médio de dominância (Figuras 1 a 4), constatou-se a presença de dominância parcial (reta de regressão interceptando o eixo das ordenadas entre o ponto "B" e "AB/2"). Isto é um indicativo de que, no caso destes experimentos, os parâmetros genéticos calculados com base nos efeitos de dominância dos genes não fornecem informações seguras, pois os componentes de dominância não diferiram significativamente de zero. Portanto, conclusões mais seguras, com relação aos parâmetros genéticos calculados, somente foram obtidas no experimento CV-JUL02, o qual será discutido com mais detalhes, com ressalvas apenas para o caráter severidade dos sintomas foliares desconsiderando as plantas com nota 1 (SP1). De qualquer forma, foram apresentados todos os resultados obtidos, para demonstrar o que pode acontecer nas referidas situações, ou seja, a presença de valores teoricamente inesperados pode ocorrer porque, na prática, não seria adequado calculá-los. Então, isto leva a crer que, as conclusões obtidas pela observação da ordem decrescente de dominância $\left(\hat{\mathrm{W}}_{\mathrm{i}}+\hat{\mathrm{V}}_{\mathrm{i}}\right)$ e da relação entre alelos favoráveis e dominância (r), no experimento conduzido no telado (Tabela 19), e também pelos gráficos de regressão linear de $\hat{W}_{i}$ em função de $\hat{V}_{i}$ (Figuras 1 e 2), não foram condizentes com a realidade, ou seja, a resistência a PVR, na sua maior parte, não foi controlada por genes recessivos, como se pode observar nos outros dois experimentos (CV-SET01 e CV-JUL02). No entanto, pelos altos valores de "r" obtidos no experimento TE-JUL01, não se descarta a hipótese de que alelos recessivos também possam estar contribuindo para aumentar a resistência a PVR. Da mesma forma, os resultados obtidos no experimento CV-SET01 (Tabela 19 e Figuras 3 e 4), devem ser observados com ressalvas, embora estejam mais de acordo com os do experimento CV-JUL02. 
Considerando o experimento conduzido na casa de vegetação em 2002 (CV-JUL02), os valores obtidos para o grau médio de dominância ( $g \hat{m} \mathrm{~d}$ ), em geral, foram elevados, variando de 1,8 a 7,0 (Tabela 19), o que demonstra a presença de sobredominância, a qual também é constatada observado-se o ponto em que a reta de regressão intercepta o eixo das ordenadas nas Figuras 5 a 10 . Pelos resultados comentados anteriormente nas análises de variância (Tabelas 16 e 17) e estimativas dos componentes genéticos (Tabela 18), somando-se a estes os gráficos apresentados nas Figuras 5 a 10, fica comprovada a existência de dominância no controle da resistência a PVR neste experimento. Porém, os valores do grau médio de dominância parecem estar superestimados (Tabela 19), principalmente, para os índices de doença dos sintomas foliares (IDF e IDP). Segundo Ferreira (1988), as fórmulas de cálculo dos componentes genéticos pelo método original de Jinks-Hayman (Jinks \& Hayman, 1953; Hayman, 1954a; Jinks, 1954) conduzem a superestimativas dos valores de $\hat{D}$ e $\hat{H}_{1}$, os quais provocariam uma superestimação no grau médio de dominância que atingiria $85 \%$ do valor deste parâmetro em um dialelo 6x6. Conforme comentado por Hayman (1954a) e por outros autores (Nassar, 1965; Baker, 1978; Ferreira, 1988), a distribuição não-independente dos genes nos genitores seria a causa de superestimativas no grau médio de dominância. Assim, quando se analisou o grau médio de dominância na subtabela sem o genitor 'Cristalina', pelos motivos já comentados anteriormente (item 4.1.5.1 a), o grau médio de dominância apresentou redução considerável (Tabela 19), apesar de ainda continuar elevado. Além disso, considerando que os presentes dialelos $(4 \times 4$ e 5×5) são de tamanho inferior ao $6 \times 6$ citado por Ferreira (1988), supõese que os graus médios de dominância aqui calculados estejam com superestimação superior a $85 \%$. Infelizmente, no presente trabalho, não foi possível a utilização das fórmulas de Ferreira (1988), pois estas foram expressas apenas para tabelas dialélicas completas (incluindo os recíprocos), com dados obtidos na geração $F_{1}$ e utilizando o erro geral, ao invés dos erros específicos $\left(E_{0}\right.$ e $\left.E_{2}\right)$.

A proporção entre o número total de alelos dominantes e recessivos nos genitores $\left(\frac{\hat{\mathrm{K}}_{\mathrm{D}}}{\hat{\mathrm{K}}_{\mathrm{R}}}\right)$ foi sempre inferior a 1,0 no experimento CV-JUL02 (Tabela 19), indicando maior freqüência de alelos recessivos nos genitores. Este resultado concorda com a tendência observada para as estimativas do componente genético $\hat{F}$, apesar de nenhuma delas ter sido significativamente diferente de zero (Tabela 18). Porém, esta relação exige que os locos tenham efeitos iguais sobre a expressão do caráter (Santos, 1984), o que é muito difícil de ocorrer na prática.

Trabalhos com marcadores moleculares ligados a QRLs da PVR demonstraram que o 
efeito de cada loco sobre a variação fenotípica da resistência é muito variável, estando entre 10 e $81 \%$, dependendo da característica avaliada (Chang et al., 1996; Hnetkovsky et al., 1996; Torto et al., 1996; Meksem et al., 1999a; Iqbal et al., 2001; Njiti et al., 2002). Especificamente para os sintomas foliares, a quantidade de variação fenotípica explicada por cada loco marcador detectado variou entre 11,5 e $24,1 \%$, entre os seis QRLs detectados entre RILs (linhagens endogâmicas recombinantes) do cruzamento 'Forrest' x 'Essex', explicando 90\% da variação fenotípica total do índice de doença (lqbal et al., 2001) (Tabela 1). Porém, apesar de serem fortemente ligados aos QRLs da PVR na população segregante utilizada, estes marcadores podem não estar representando o verdadeiro efeito médio de cada loco (QRL) responsável pela resistência a PVR, pois não são os genes propriamente ditos, e sim apenas marcadores moleculares, cuja distância entre cada um e o respectivo gene de resistência a PVR pode variar em outras populações segregantes ou cultivares. Neste sentido, utilizando RILs do cruzamento 'Pyramid' x 'Douglas', Njiti et al. (2002) encontraram outros marcadores moleculares microssatélites ligados a dois QRLs já relatados por lqbal et al. (2001). De qualquer forma, como entre as cinco cultivares utilizadas apenas duas ('Forrest' e 'Conquista') apresentam resistência parcial a PVR, este parâmetro confirma o baixo nível de esistência geral observado no grupo dos genitores, sugerindo o predomínio de alelos recessivos e reforçando a evidência de que a resistência a PVR é controlada por genes que exibem dominância.

O produto das freqüências médias dos alelos de efeitos positivos e negativos nos locos em que ocorre dominância ( $\overline{\mathrm{i} v}$ ), variou entre 0,20 e 0,23 (Tabela 19). Isto indica a presença de pequena assimetria na distribuição dos alelos positivos e negativos nos genitores, a qual foi mais acentuada quando as análises dialélicas foram realizadas com todos os genitores, ou seja, sem a exclusão do genitor 'Cristalina', demonstrando que esta cultivar, embora classificada como suscetível, deve conter genes de resistência que interferem na manifestação dos sintomas foliares da PVR. Também se observou que, para o índice de doença dos sintomas foliares, os valores do parâmetro $\overline{i v}$ foram exatamente iguais quando nas avaliações se considerou a nota do folíolo com sintomas mais intensos (IDF) ou o aspecto geral da planta (IDP). Comparando-se estes resultados com aqueles das análises de variância, as significâncias e tendências observadas para o componente " $b_{2}$ " (Tabelas 16 e 17) concordam com os resultados aqui obtidos (Tabela 19), embora algumas estimativas dos componentes genéticos $\hat{H}_{1}$ e $\hat{H}_{2}$ não foram significativamente maiores que zero (Tabela 18).

A constância da relação entre efeitos de dominância e efeitos aditivos nos locos que exibem dominância $[(\grave{i}-\mathrm{v}) \mathrm{h} / \mathrm{d}]$, variou entre 0,87 e 1,67 (Tabela 19). O valor máximo teórico 
esperado é 1,0 e a estimativa deste parâmetro só tem validade quando a freqüência dos alelos dominantes e recessivos for diferente. Como esta segunda condição deve estar sendo atendida, conforme se observa pelos valores estimados de $\hat{K}_{D} / \hat{K}_{R}$, então pode ser que a magnitude das estimativas dos componentes genéticos é que esteja distorcendo os resultados, visto que nenhuma das estimativas de $\hat{D}$ e $\hat{F}$ foi significativamente diferente de zero (Tabela 18). Por outro lado, apesar dos valores anormais encontrados, a fórmula utilizada parece ser a mais adequada, por aceitar valores de $\hat{F}$ negativos, sendo a que Mather \& Jinks (1982, p.258) utilizaram no seu exemplo numérico, deduzindo-a um pouco mais. Pelos valores obtidos para a severidade (SF) e índice de doença (IDP sem o genitor 'Cristalina') dos sintomas foliares da PVR, os quais estão próximo de 1,0 , é evidenciada a contribuição uniforme de todos os locos para o grau médio de dominância, indicando que os efeitos gênicos de dominância (h) e os efeitos gênicos aditivos (d) foram constantes entre os locos que exibiram dominância.

O número de fatores efetivos $(\hat{N})$ variou entre 2,01 e 2,95, sendo as estimativas um pouco maiores quando se considerou o aspecto geral da planta na avaliação dos sintomas foliares da PVR (Tabela 19). Os resultados obtidos indicaram que existem, pelo menos, três locos ou blocos gênicos que exibiram dominância e conferiram resistência à manifestação dos sintomas foliares da PVR, devendo este caráter ser controlado por maior número de locos, pois efeitos gênicos aditivos também foram constatados (Tabelas 16 e 17). Normalmente, este valor é subestimado, pois não considera os locos que exibem pouca ou nenhuma dominância, além de exigir que os efeitos de dominância dos locos sejam iguais em magnitude e direção e que a distribuição dos genes nos genitores seja independente (Jinks, 1954). Neste sentido, de forma geral, observou-se que os efeitos de dominância dos locos foram aproximadamente iguais em magnitude e direção, porém, conforme já comentado, por causa da cultivar Cristalina, a condição de independência na distribuição dos genes entre os genitores não foi atendida, havendo tendência de um pequeno acréscimo na estimativa de $\hat{\mathrm{N}}$ com a exclusão deste genitor (Tabela 19). Conforme Ferreira (1988), as subestimações observadas em seu trabalho atingiram, aproximadamente, $70 \%$ do valor deste parâmetro, embora este se referiu ao número de blocos gênicos calculado pela fórmula de Hayman (1954a), ou seja, $\hat{h}^{2} / \hat{H}_{2}$. Porém, esta fórmula é quase idêntica a do número de fatores efetivos $(\hat{N})$ aqui utilizada, sendo a única diferença que o numerador, o qual corresponde ao componente genético $\hat{h}^{2}$ de Hayman (1954a), apresenta correção para o efeito ambiental. Assim, segundo cálculos realizados paralelamente com o erro geral (pois não se dispõe de uma fórmula para o cálculo de $\hat{h}^{2}$ adaptada para meias tabelas dialélicas com dados da geração $F_{2}$ e que utilize os erros 
específicos de genitores e cruzamentos), utilizando a expressão fornecida por Ferreira (1985) e adaptando-a para a geração $F_{2}$, esta forneceu estimativas pouco inferiores que as obtidas para $\hat{\mathrm{N}}$. Com relação à severidade dos sintomas foliares desconsiderando as plantas com nota 1 (SP1), o valor de $\hat{\mathrm{N}}$ igual a 0,52 com certeza, não condiz com a realidade. Isto porque, em trabalhos efetuados com marcadores moleculares, embora em avaliações a campo, já foram detectados sete QRLs condicionando resistência a PVR (Chang et al., 1996; Hnetkovsky et al., 1996; Iqbal et al., 2001; Njiti et al., 2002; Triwitayakorn et al., 2002). Como estes trabalhos utilizaram como genitor resistente a cultivar Forrest, a qual apresentou cinco dos sete QRLS relatados, novamente se confirma a subestimação do número de locos que controlaram a resistência a PVR, pois esta cultivar também foi incluída no presente dialelo. Além disso, nas outras cultivares que participaram do dialelo, provavelmente, devem haver outros locos contribuindo para o controle da resistência a PVR, pois os alelos de resistência podem estar presentes tanto em genitores resistentes como suscetíveis à doença, conforme já demonstrado (Chang et al., 1996; Hnetkovsky et al., 1996; Njiti et al., 1998a e 2002; lqbal et al., 2001).

A herdabilidade no sentido restrito $\left(\hat{h}_{r}^{2}\right)$ foi pouco maior quando se considerou a severidade dos sintomas foliares da PVR (SF, SP e SP1), ficando em torno de 0,60 (Tabela 19). Quando se considerou o índice de doença dos sintomas foliares, os valores estimados foram um pouco menores, reduzindo-se ainda mais com a exclusão da cultivar Cristalina. De certa forma, este comportamento acompanhou as diferenças em magnitude observadas entre as estimativas dos componentes genéticos aditivos e de dominância para os caracteres avaliados (Tabela 18). Assim, menor discrepância entre as variâncias genéticas aditivas $(\hat{D})$ e de dominância $\left(\hat{H}_{1}\right)$ foi observada para a severidade dos sintomas foliares (SF e SP) e, maior, para o índice de doença excluindo-se a cultivar Cristalina, indicando que os efeitos de dominância foram mais expressivos sobre o controle da resistência a PVR quando esta foi avaliada com base no índice de doença. Estes valores de herdabilidade foram inferiores aos obtidos em experimentos de campo com linhagens, os quais variaram entre 0,68 e 0,83 para a severidade dos sintomas foliares da PVR, sendo de 0,75 na média de seis ambientes (Njiti et al., 1996). Na média de cinco locais, Chang et al. (1996) obtiveram herdabilidade de 0,78 para a severidade dos sintomas foliares da PVR em "RILs" (linhagens endogâmicas recombinantes) $F_{11: 5}$ do cruzamento 'Forrest' $x$ 'Essex'. Na média de quatro locais, Meksem et al. (1999a) obtiveram herdabilidade de 0,70 para o índice de doença na parte aérea e de 0,78 para a severidade de infecção nas raízes em "NILs" (linhagens quase isogênicas) $F_{11: 9: 5}$ também do cruzamento 'Forrest' x ‘Essex'.

A herdabilidade no sentido amplo $\left(\hat{h}_{a}^{2}\right)$ apresentou comportamento inverso (Tabela 19), 
ou seja, foi pouco menor quando se considerou apenas a severidade dos sintomas foliares da PVR (SF e SP), indicando que a severidade foi afetada pelo ambiente em proporção pouco maior que o índice de doença. Para o caso da severidade sem considerar as plantas com nota 1 (SP1), o valor obtido reforçou ainda mais a presença de somente ação gênica aditiva. De maneira geral, confirmou-se a presença de ação gênica aditiva e de dominância no controle da resistência a PVR neste experimento, além de que as herdabilidades no sentido amplo foram elevadas. Provavelmente, o uso de um grande número de repetições reduziu a participação dos erros experimentais, resultando em valores altos para as herdabilidades no sentido amplo.

A ordem decrescente de dominância, ou seja, a ordem crescente da soma $\hat{W}_{i}+\hat{V}_{i}$, para cada caráter analisado, está apresentada na Tabela 19, juntamente com a relação entre alelos favoráveis e dominância (r); e os gráficos das análises de regressão linear de $\hat{W}_{i}$ em função de $\hat{V}_{i}$ estão apresentados nas Figuras 1 a 11.

No experimento TE-JUL01, para a severidade dos sintomas foliares da PVR, a classificação das cultivares, pela ordem decrescente de dominância, foi a seguinte: 'Estrela', 'Cristalina', 'IAC-4', 'Conquista' e 'Forrest' (Tabela 19 e Figura 1). As cultivares Estrela e Cristalina situaram-se na extremidade inferior esquerda do gráfico, demonstrando apresentarem mais genes dominantes, enquanto 'IAC-4' e 'Conquista' situaram-se em posição intermediária, apresentando genes dominantes e recessivos em proporção semelhante; já 'Forrest' situou-se na extremidade superior direita, demonstrando apresentar mais genes recessivos. Como a relação entre alelos favoráveis e dominância ( $r$ ) foi $-0,70$ (Tabela 19), além de que a cultivar Forrest foi a mais resistente a PVR, isto indicou que os alelos recessivos foram os responsáveis pelo controle genético da resistência a PVR, avaliada pela severidade dos sintomas foliares, neste experimento. Porém, pela significância apenas dos efeitos gênicos aditivos (Tabela 15), estes resultados devem ser interpretados com ressalvas, apesar de, graficamente, ter se detectado a presença de dominância parcial (Figuras 1 e 2).

Para o índice de doença dos sintomas foliares (IDF), também no experimento TEJUL01, a situação foi semelhante, sendo a ordem decrescente de dominância a seguinte: 'Cristalina', 'Estrela', 'IAC-4', 'Conquista' e 'Forrest' (Tabela 19), com as quatro primeiras cultivares se localizando na extremidade inferior esquerda do gráfico e, 'Forrest', na extremidade superior direita (Figura 2). Neste caso, o valor de "r" foi de -0,94 (Tabela 19), o que forneceu um valor de " $r$ " de 0,88 , permitindo que se estimassem os limites teóricos de seleção com precisão aceitável. Assim, o valor estimado de índice de doença para o genitor com máxima concentração de alelos dominantes $\left(\hat{Y}_{D}\right)$ foi de 39,5 e, de alelos recessivos $\left(\hat{Y}_{R}\right)$, foi de 19,9, indicando a possibilidade de se selecionar, nas populações segregantes derivadas do 
dialelo, genótipos ainda mais resistentes a PVR.

No experimento conduzido na casa de vegetação em 2001 (CV-SET01), a ordem decrescente de dominância nas cultivares alterou-se bastante, tanto para a severidade quanto para o índice de doença dos sintomas foliares da PVR (Tabela 19 e Figuras 3 e 4). Para a severidade (SF), a ordem decrescente de dominância das cultivares foi: 'Forrest', 'Estrela', 'Conquista', 'IAC-4' e 'Cristalina', sendo que 'Forrest' e 'Cristalina' inverteram totalmente de posição em relação ao experimento TE-JUL01, enquanto que 'Estrela' passou para uma posição intermediária, e 'Conquista' e 'Estrela' continuaram na porção intermediária (Figuras 1 e 3). Pelo valor de "r" igual a 0,05 (Tabela 19), há ausência de dominância direcional, ou seja, alguns locos que exibiram dominância contribuíram para aumentar a resistência a PVR e, outros, para diminuir, indicando que, neste caso, a resistência estaria sendo controlada por uma mistura de genes dominantes e recessivos. Quanto ao índice de doença (IDF), a ordem decrescente de dominância foi a seguinte: 'Forrest', 'IAC-4', 'Conquista', 'Estrela' e 'Cristalina', a qual foi praticamente a inversa da observada no experimento TE-JUL01 (Tabela 19), sendo que apenas 'IAC-4' tendeu a permanecer na mesma posição, mas, na margem da parábola limitante (Figuras 2 e 4). O valor de "r" foi 0,44 (Tabela 19), demonstrando a presença de dominância direcional, sendo que os genes dominantes contribuíram para aumentar a resistência a PVR. De maneira semelhante aos resultados anteriores, observou-se significância apenas dos efeitos gênicos aditivos neste experimento (Tabelas 15 e 18), fato este que impõe ressalvas nas interpretações dos parâmetros genéticos e dos gráficos feitos com base nos efeitos gênicos de dominância, embora, graficamente, constata-se a presença de dominância parcial (Figuras 3 e 4). Por outro lado, o comportamento diferenciado das cultivares nos dois experimentos, quanto à ordem de dominância, poderia estar demonstrando que os genes dominantes, responsáveis pela resistência a PVR, foram influenciados de maneira diferente pelos fatores ambientais, conforme sugerido por Santos (1984). Reforçam esta idéia as observações de Crumpacker \& Allard (1962), de que o comportamento instável de alguns genótipos, em diferentes ambientes, foi associado em magnitude muito maior com a instabilidade dos efeitos gênicos de dominância do que com a instabilidade dos efeitos gênicos aditivos. Comportamento diferente de cultivares para um mesmo caráter, quanto à ordem de dominân cia em ambientes diferentes, também foi observado por outros autores (Park \& Davis, 1976; Santos, 1984; Lopes, 2001), havendo genitores com comportamento mais estável do que outros.

No experimento CV-JUL02 a ordem de dominância foi quase sempre a mesma, sendo a seguinte: 'Conquista', 'Cristalina', 'Forrest', 'Estrela' e 'IAC-4', havendo apenas alteração da ordem entre 'Cristalina' e 'Forrest' para a severidade dos sintomas foliares desconsiderando as plantas com nota 1 (Tabela 19). Nos gráficos de regressão também se observa que 'Conquista' e 'IAC-4' apresentaram a maior e menor concentração de genes dominantes, respectivamente; 
porém, entre os outros três genitores, localizados em posições intermediárias nos gráficos, é necessário considerar a distância entre cada um e o ponto de origem. Para os caracteres SF, IDF e IDP, 'Cristalina' apresentou maior concentração de genes dominantes que 'Forrest' (Figuras 5, 6 e 9), enquanto que para SP a concentração de genes dominantes em 'Cristalina' foi igual a de 'Forrest' (Figura 8).

Como se pode observar nas Figuras 7 e 10, com a exclusão de 'Cristalina', os valores de " $r$ " aumentaram consideravelmente, assim como o valor do coeficiente de regressão linear $(\hat{b})$, indicando que a ausência desta cultivar no dialelo ajudou a melhorar a adequação dos dados ao modelo genético aditivo-dominante de Jinks-Hayman, conforme já constatado anteriormente (Tabela 14), por ter ancestrais em comum com 'Estrela' e, provavelmente, com 'Conquista'. Conforme se pode observar nas Figuras 5, 6, 8 e 9, a cultivar Cristalina também tendeu a se situar em posição marginal à parábola limitante, o que é mais um indicativo da sua influência negativa no ajuste dos dados ao modelo genético. Além disso, também chama atenção o fato de que, para o índice de doença, foram obtidos valores de $\hat{W}_{\mathrm{i}}$ negativos (Figuras 6, 7, 9 e 10), cuja presença persistiu mesmo após a exclusão de 'Cristalina' do dialelo (Figuras 7 e 10). Segundo Nassar (1965), este tipo de ocorrência não é incomum, sendo um forte indicativo de que existe interação em alguns dos cruzamentos. Porém, não foram feitas análises especulativas procurando identificar estes possíveis cruzamentos e substituí-los por estimativas, visto que, nos casos em que isto ocorreu, ainda houve boa adequação dos dados ao modelo genético aditivo-dominante de Jinks-Hayman.

Com relação à severidade dos sintomas foliares da PVR desconsiderando as plantas com nota 1 (SP1), como apenas os efeitos gênicos aditivos foram significativos (Tabelas 16 e 18), o gráfico de regressão de $\hat{W}_{i}$ em função de $\hat{V}_{i}$ deve ser interpretado com ressalvas, apesar de ter sido constatada, graficamente, a presença de dominância parcial (Figura 11) e da ordem de dominância nas cultivares ter sido semelhante à esperada (Tabela 19), com exceção da posição de 'Cristalina' no gráfico (Figura 11).

\subsubsection{Experimento de campo com a geração $F_{3: 2}$}

A análise de resíduos deste experimento indicou ausência de normalidade dos resíduos e de homogeneidade de variâncias dos tratamentos para todos os caracteres analisados, mesmo após a transformação para $\log (\mathrm{x})$ dos dados de número de dias para maturidade, altura da planta e produtividade de grãos por planta e, para $\sqrt{x+0,5}$, dos dados de valor agronômico. 
Esta ausência de normalidade, provavelmente, é conseqüência da análise realizada com base em dados de plantas individuais (parcelas em covas com apenas uma planta) sendo, talvez, mais adequado se utilizar parcelas com 12 covas de plantas individuais, procedendo-se à avaliação de plantas individuais e depois calculando-se a média de parcelas, conforme utilizado por outros autores que utilizaram o método SHDT - descendência de uma única cova desbastada (Nass, 1989; Gomes, 1995; Alliprandini, 1996; Lopes, 2001). Quanto à homogeneidade de variâncias, por se tratar de geração $F_{3: 2}$ e contendo alguns cruzamentos bastante contrastantes com relação à características agronômicas de seus genitores (Tabelas 20 e 21), este resultado já era esperado. Porém, pela grande desuniformidade observada entre as variâncias dos genitores, principalmente para os caracteres número de dias para a maturidade e produtividade de grãos por planta, isto reforça a necessidade de se utilizar parcelas com várias covas para tornar possível a realização da análise de variância com dados médios de parcelas. De qualquer forma, nesta etapa, a média e variância de cada cruzamento $F_{3: 2}$ já são um bom indicativo do seu potencial para a seleção em gerações posteriores e um dos principais objetivos é discriminar os melhores dos piores cruzamentos. Assim, procedeu-se somente à apresentação dos resultados em termos de médias e variâncias, juntamente com a ordem decrescente de classificação, a qual foi colocada separada para cruzamentos e genitores (Tabelas 20 e 21). Especificamente para a média do número de dias para maturidade, a ordem crescente de classificação seria a mais importante, pelo maior interesse nos genótipos mais precoces. Então, para facilitar a visualização conjunta com os melhores genótipos para todos os caracteres, os genótipos foram classificados em ordem crescente do número de dias para maturidade, ou seja, em ordem decrescente de precocidade, de forma que os melhores genótipos foram sempre os primeiros colocados para todos os caracteres.

De maneira geral, os cruzamentos 'Conquista' x 'Cristalina', 'Cristalina' x 'Estrela' e 'Conquista' $\mathrm{x}$ 'Estrela' apresentaram as maiores médias para produtividade de grãos por planta, altura da planta e valor agronômico, assim como as maiores variâncias para produtividade de grãos por planta e altura da planta (Tabela 20). No entanto, 'Conquista' x 'Cristalina' e 'Cristalina' $x$ 'Estrela' apresentaram as maiores médias e menores variâncias para o número de dias para a maturidade, sendo os cruzamentos mais tardios e com menor segregação para a duração do ciclo total. No outro extremo ficaram os cruzamentos 'Estrela' x 'Forrest' e 'Forrest' $x$ 'IAC-4', os quais foram os mais precoces, mas com as menores médias e variâncias para altura da planta, produtividade de grãos por planta e valor agronômico (Tabela 20). O cruzamento 'Conquista' x 'Forrest', o qual seria o de maior interesse por ter ambos os genitores resistentes a PVR, segregação para resistência ao CHS e boa média e variância para precocidade, esteve entre aqueles que apresentaram as menores médias e variâncias para os demais caracteres avaliados. Desta forma, para aumentar a chance de sucesso na seleção de indivíduos mais 
resistentes a PVR e com bons caracteres agronômicos neste cruzamento, uma das alternativas seria a condução de um maior número de indivíduos, decisão que já poderia ter sido tomada na geração $F_{2}$ com base apenas nas características destes dois genitores. Como a cultivar Forrest é um genótipo exótico e considerado "clássico" quanto ao período juvenil, já era esperado este comportamento na maioria dos cruzamentos em que participou, apresentando maior potencial apenas quando cruzada com a cultivar Cristalina, a qual foi a mais tardia e a mais produtiva (Tabela 20).

Quando se uniformizou o número de plantas avaliadas nos cruzamentos para apenas 27, correspondendo a 27 repetições, embora estas não o sejam no sentido exato deste termo, visto que cada repetição foi representada por um genótipo $F_{3: 2}$ diferente, apesar de pertencerem a um mesmo cruzamento, e que, originalmente, a maioria dos cruzamentos apresentava mais do que 27 repetições, os resultados foram idênticos ou muito semelhantes (Tabela 21). Assim, embora ocorreram pequenas diferenças nas magnitudes dos valores, pode-se dizer que se obteve praticamente a mesma ordem de classificação do que na avaliação com todas as plantas para as médias de todos os caracteres avaliados, assim como para as variâncias da produtividade de grãos por planta (Tabelas 20 e 21). Com relação aos melhores e piores cruzamentos se chegaram às mesmas conclusões já comentadas, apesar de ser apenas um experimento e com poucos tratamentos. Isto demonstrou que, utilizando-se o método SHDT, a avaliação de apenas 27 parcelas de plantas individuais (covas) de cada cruzamento poderia ser o suficiente para indicar o seu potencial de seleção, em gerações mais avançadas de autofecundação, para as características agronômicas avaliadas, desde que o potencial agronômico apresentado na semeadura em covas seja correspondente àquele apresentado em cultivos em fileiras.

Neste sentido, embora com semeadura em 21/01 e utilização de irrigação complementar, Nass (1989) comparou a utilização de parcelas com nove covas (SHDT), espaçadas de $0,60 \mathrm{~cm}$ e com cinco repetições (totalizando 45 plantas em cada tratamento), e fileiras de 1,0 e 3,0 m de comprimento (com 16 plantas $/ \mathrm{m}$ ), também espaçadas de 0,60 m e com quatro repetições, na geração $F_{2}$ de um dialelo $10 \times 10$. Nas 39 comparações (30 populações $F_{2}$ e nove genitores) que foram possíveis entre as parcelas em covas e fileiras de $1,0 \mathrm{~m}$, o autor obteve correlações fenotípicas elevadas e altamente significativas para o número de dias para a maturidade $(r=0,94)$, número de internódios na maturidade $(r=0,75)$, altura da planta na maturidade $(r=0,74)$, valor agronômico $(r=0,70)$ e produtividade de plantas individuais $(r=0,62)$, as quais, na maioria dos casos, foram pouco menores nas 19 comparações possíveis entre covas e fileiras de 3,0 m. Toledo (1993) utilizou covas espaçadas de 0,20 m e bordaduras em fileiras, com densidade normal e espaçamento de $0,50 \mathrm{~m}$, em comparação com o sistema tradicional (quatro fileiras de 5,0 m e espaçamento de 0,50 m), e obteve correlação de posto de 
0,74 entre a ordem de classificação das cultivares em ambos os sistemas. Também utilizando o método SHDT, Alliprandini (1996), fazendo avaliações nas gerações $F_{2}$ e $F_{3: 2}$, concluiu que este método foi eficiente para a condução de um grande número de populações com tamanho efetivo adequado, sendo este, em média, de 39 plantas. Nass (1989) já havia utilizado apenas 45 plantas de cada população $F_{2}$. Já Gomes (1995) comparou a utilização de parcelas com 12 covas, espaçadas de 0,5 m, na geração $F_{6}$ de 44 cruzamentos, com fileiras $F_{7: 6}$ de 2,0 m de comprimento e espaçamento de $0,5 \mathrm{~m}$, e observou correlação média de $-0,07$ (variando de 0,63 a 0,43 ) para a produtividade de grãos e de 0,27 (variando de $-0,43$ a 0,76 ) para o valor agronômico. Porém, estes dois experimentos foram conduzidos em anos diferentes e como há elevada interação genótipos $x$ ambientes, os valores de correlação, provavelmente, estão mascarados, principalmente para a produtividade de grãos. Segundo Toledo ${ }^{3}$, durante a condução de gerações em "bulks", a avaliação de 40 a 50 plantas individuais $F_{3}$, tomadas ao acaso de cada cruzamento, com base nas suas médias e variâncias, já seria um bom indicativo do seu potencial para a seleção em gerações mais avançadas. Pelos resultados obtidos, utilizando-se covas, este número poderia ser reduzido para, praticamente, a metade. Porém, implicaria em utilização de mão-de-obra e espaço adicional se as gerações de autofecundação estivessem sendo conduzidas por outro método. Caso as populações segregantes estivessem sendo conduzidas pelo método SHDT, provavelmente em número maior de covas que o utilizado, usualmente 72 (6 repetições x 12 plantas/parcela), segundo Vello (1992), para não restringir em demasia a variabilidade genética, então apenas uma parte delas, tomadas ao acaso em $\mathrm{F}_{3: 2}$ poderia ser avaliada, conforme aqui efetuado.

Um procedimento sugerido para ser testado seria a semeadura de 72 (no máximo 96) covas desbastadas de $F_{3: 2}$ para cada cruzamento, constituindo-se parcelas com seis ou oito covas, e avaliar apenas cinco ou quatro repetições, respectivamente (30 e 32 plantas avaliadas individualmente, respectivamente) em cada cruzamento. Nas gerações seguintes, os cruzamentos de interesse poderiam continuar sendo conduzidos em covas (método SHDT), ou então em "bulks", ou fileiras de 2,0 m ou, outro método, a critério do melhorista. Um método que vem sendo utilizado na Embrapa Soja, para a condução e avaliação de populações segregantes, é a utilização do delineamento inteiramente casualizado, com aleatorização individual de plantas, no método SHDT, com espaçamento entre covas na fileira e entre linhas, de $0,20 \mathrm{~m}$ e $1,5 \mathrm{~m}$, respectivamente; entre cada fileira útil (covas) são semeadas duas fileiras de bordadura, na densidade comercial, resultando no espaçamento final de 0,50 m entre fileiras (Arias et al., 1999).

\footnotetext{
${ }_{3}^{3}$ TOLEDO, J.F.F. Programa de melhoramento de soja da Embrapa Soja. Palestra proferida em visita técnica a Embrapa Soja, Londrina, 2001.
} 
Pelos resultados obtidos nas Tabelas 20 e 21, houve alta correlação fenotípica entre as médias de produtividade de grãos por planta e o valor agronômico nas duas situações, respectivamente, 0,82 e 0,83 , ambas altamente significativas $(P<0,01)$, conseguindo-se separar os três piores cruzamentos ('Forrest' x 'IAC-4', 'Conquista' x 'Forrest' e 'Estrela' x 'Forrest'), assim como o melhor ('Conquista' x 'Cristalina'), para a produtividade de grãos por planta, com base no valor agronômico, havendo também boa correspondência para a colocação dos demais cruzamentos. Além disso, também houve correspondência entre a variância da produtividade de grãos por planta e do valor agronômico dos dois piores cruzamentos ('Estrela' x 'Forrest' e 'Forrest' x 'IAC-4'). Isto leva a crer que, durante a condução de populações segregantes pelo método SHDT, talvez seja possível tomar como única medida o valor agronômico de plantas individuais $F_{3: 2}$, podendo este ser avaliado em todas as plantas dos cruzamentos ou em apenas parte destas (cerca de 30), como demonstrado (Tabelas 20 e 21), para se ter um indicativo do potencial de cada um para a seleção em gerações mais avançadas de autofecundação, com base nos caracteres avaliados, se houver correspondência entre o valor agronômico de plantas semeadas em covas e em fileiras. Como o comportamento agronômico das plantas na semeadura em covas teve alta correlação fenotípica $(r=0,70)$ com a semeadura em fileiras de 1,0 m (Nass, 1989), este é mais um fator que demonstra a possibilidade de utilização do valor agronômico, o qual equivale à seleção visual comumente utilizada no método genealógico. Como o número de dias para a maturidade e o valor agronômico foram menos influenciados pelo ambiente, Gomes (1995) também sugeriu que linhagens superiores em produtividade poderiam ser selecionadas pelo seu valor agronômico. No entanto, Alliprandini (1996) concluiu que a seleção precoce de plantas em $\mathrm{F}_{2}$ foi mais eficiente quando se utilizou conjuntamente os caracteres produtividade de grãos, valor agronômico e número de dias para a maturidade, combinados em um índice de seleção.

Com relação às cultivares, houve inversão das posições entre 'Cristalina' e 'Conquista' e entre 'Estrela' e 'IAC-4', quando se considerou o valor agronômico em comparação com a produtividade de grãos por planta, embora com diferenças pequenas (Tabelas 20 e 21). Provavelmente, entre 'Cristalina' e 'Conquista', isto tenha ocorrido por causa do ciclo mais tardio de 'Cristalina', desfavorecendo-a na avaliação visual de seus caracteres agronômicos. Além disso, observou-se que as variâncias de 'Cristalina' e de 'Estrela' para a produtividade de grãos por planta, em comparação com 'Conquista' e 'IAC-4', respectivamente, foram bem maiores, o que deve ter se refletido com maior intensidade na nota de valor agronômico das plantas menos produtivas. Desta forma, a presença de plantas pouco produtivas e que receberam uma nota bastante baixa de valor agronômico deve ter sido o principal motivo para reduzir a média de valor agronômico de 'Cristalina' e de 'Estrela'. Por outro lado, as elevadas variâncias de 'Cristalina' e 'Estrela' demonstram a presença de elevada interação genótipos $x$ ambientes. 
Moreira (1992) trabalhou com a geração $F_{3}$ (semeadura em 07/02), em parcelas constituídas de 15 covas espaçadas de 0,2 × 0,6 m, colocando uma fileira de bordadura, com densidade de 20 plantas $/ \mathrm{m}$, entre cada parcela, e também obteve variâncias elevadas dentro dos genitores, observando que, dentre os 44 cruzamentos avaliados, 79,5\% apresentaram interação genótipos $x$ ambientes para a produtividade de grãos por planta, e que $88,6 \%$ dos cruzamentos apresentaram efeitos aditivos significativos, enquanto que $40,9 \%$ apresentaram efeitos de dominância significativos para este caráter. Apesar da semeadura fora da época tradicional, este experimento demonstrou que os efeitos de dominância presentes na geração $F_{3}$ foram inferiores aos efeitos aditivos, correspondendo a cerca de $50 \%$ destes, o que aumenta a garantia dos resultados obtidos no teste de geração precoce em $F_{3}$ para a produtividade de grãos.

\subsection{Utilização de marcadores moleculares}

\subsubsection{Genotipagem das cultivares}

Inicialmente, para os marcadores microssatélites, foram utilizados géis de agarose a 3 ou $3,5 \%$ para esta etapa mas, com a constatação de multialelismo, ou seja, da presença de mais de dois fragmentos de DNA amplificados (bandas) entre as cultivares genotipadas, foram utilizados géis de poliacrilamida a $6 \%$, apenas com as cinco cultivares incluídas nos estudos com a geração $F_{2}$ ('Forrest', 'Conquista', 'IAC-4', 'Cristalina' e 'Estrela'). Porém, como nem todos os alelos de resistência estão presentes em 'Forrest' (utilizada também como uma testemunha resistente) e como apenas o marcador Satt163 não apresentou multialelismo para estas cinco cultivares, as dúvidas de interpretação ainda persistiram, mesmo em gel de poliacrilamida. Assim, foi necessária a obtenção de sementes da cultivar americana suscetível Essex, a qual participou, junto com 'Forrest', dos experimentos para a detecção de ligação dos marcadores moleculares utilizados, no trabalho de lqbal et al. (2001). Desta forma, após a extração de DNA de plantas da cultivar Essex, novas genotipagens foram efetuadas, somente em géis de poliacrilamida, com todas as dez cultivares, cujos resultados estão apresentados na Tabela 22 e na Figura 12.

Confirmou-se a presença dos alelos marcadores de resistência na cultivar Forrest para os marcadores Satt163, Satt309, Satt570 e OPE02 1000 (ou OE02 ${ }_{1000}$ ) e dos alelos marcadores de suscetibilidade para Satt354 e Satt371 (Tabela 22), abrangendo-se todos os seis QRLs relatados por lqbal et al. (2001). Porém, não se conseguiu boa definição dos fragmentos amplificados com os marcadores Satt163 e Satt371, mesmo em géis de poliacrilamida 6\% 
(Figura 12). Para 0 marcador RAPD OPE02 ${ }_{1000}$ também restaram algumas dúvidas de interpretação, mesmo após a realização de seis eletroforeses em gel de agarose a 1,4\% (Figura 12).

Pela Tabela 22, a cultivar brasileira Conquista, tida como resistente a PVR apresentou os alelos marcadores de resistência em apenas um (Satt354) dos seis QRLs considerados, indicando que a maior parte de sua característica de resistência, provavelmente, seja devida à presença de outros QRLs no seu genoma. Porém, se confirmada a presença dos alelos de resistência en OPE02 ${ }_{1000}$, a maior parte da sua resistência pode ser devida à presença deste QRL, pois Chang et al. (1996) citam que o QRL ligado ao marcador OPE02 $2_{1000}$ foi o mais fortemente associado com a severidade dos sintomas foliares da PVR entre os quatro QRLs até então detectados. lqbal et al. (2001) também fazem um comentário sobre este marcador, citando que as linhagens mais resistentes, com base na incidência da doença, foram aquelas que apresentaram os alelos de resistência dos marcadores OPE02 ${ }_{1000}$ e Satt371.

Com relação à cultivar IAC-4, tida como moderadamente resistente a PVR, esta apresentou os alelos marcadores de resistência em dois QRLs (Satt163 e OPE02 ${ }_{1000}$ ), podendo também apresentar os alelos marcadores de resistência do QRL ligado ao marcador Satt309. Porém, na avaliação fenotípica, geralmente, ela se comportou como suscetível, conforme verificado no primeiro teste de inoculação e nos experimentos TE-JUL01 e CV-JUL02 (Tabela 4 e Apêndices 8 e 10). Já as cultivares suscetíveis Estrela e Cristalina apresentaram os alelos de resistência em apenas um loco marcador (Satt163 e Satt354, respectivamente) e, embora 'Cristalina' tenha deixado dúvidas quanto ao marcador Satt309, de maneira geral, a avaliação fenotípica comprovou a maior suscetibilidade destas cultivares (Tabelas 4 e 5 e Apêndices 8, 9 e 10).

Quanto æ̀ demais cultivares, SS -1 apresentou os alelos marcadores de resistência de três QRLs (Satt163, Sat354 e OPE02 ${ }_{1000}$ ), confirmando apenas os resultados do primeiro teste de inoculação (Tabela 4), enquanto que 'IAC-8' e 'IAC-8-2' apresentaram os alelos marcadores de resistência de apenas um QRL (Satt354). 'IAC-8' apresentou uma certa discordância entre os testes de inoculação (Tabelas 4, 5 e 6), enquanto que 'IAC-8-2' confirmou os resultados do único teste de inoculação em que participou (Tabelas 5 e 6). Por outro lado, a cultivar Ripley, tida como resistente a PVR nos Estados Unidos, apresentou apenas os alelos marcadores de resistência de dois QRLs (Satt163 e OPE02 ${ }_{1000}$ ), de certa forma confirmando os resultados do primeiro teste de inoculação, situação em que foi a mais suscetível a PVR (Tabela 4).

Quanto ao marcador Satt038, citado em alguns trabalhos como associado com a resistência a PVR (Bell-Johnson et al., 1998; Prabhu et al., 1999; Njiti et al., 2002) e localizado próximo aos marcadores Satt163 e Satt309, comprovou-se a presença dos alelos de resistência de 'Forrest' e de suscetibilidade de 'Essex' (Tabela 22). As cultivares Conquista, IAC-4, IAC-8 e 
Cristalina também apresentaram os alelos de resistência e não foi possível fazer nenhuma associação com a presença dos alelos de Satt163 ou Satt309 nas cultivares avaliadas, de forma que ainda restam dúvidas se Satt038 representaria ou não um outro QRL ou se realmente também poderia ser utilizado na seleção auxiliada por marcadores.

Pela diversidade alélica apresentada, apesar do pequeno número de cultivares utilizado, provavelmente, os alelos de resistência dos marcadores Satt371 e Satt570, e talvez Satt309, estejam presentes em menor freqüência nas cultivares brasileiras, dificultando o acúmulo de alelos de resistência nos cruzamentos efetuados nos programas de melhoramento. Porém, pelas diferentes combinações alélicas observadas e pelos resultados da avaliação fenotípica, parece ser perfeitamente possível o "piramidamento" de QRLs durante o desenvolvimento de linhagens mais resistentes a PVR, desde que se conheça quais genes de resistência cada genitor contém. Neste sentido, os marcadores moleculares citados poderiam ser utilizados para a escolha de genitores em cruzamentos direcionados para este objetivo.

\subsubsection{Análise de ligação no cruzamento 'Conquista' $x$ 'Estrela'}

Pelos resultados apresentados na Tabela 22, foi possível utilizar os marcadores Satt163 e Satt354 para genotipar as plantas $F_{2}$ provenientes do cruzamento 'Conquista' x 'Estrela', em gel de agarose $3 \%$.

Como em 2001 os sintomas foliares das plantas $F_{2}$ avaliadas na casa de vegetação (CV-SET01) foram menos severos que no experimento do telado (TE-JUL01), optou-se por trabalhar somente com as amostras de folhas coletadas no experimento TE-JUL01, embora também neste a severidade dos sintomas tenha ficado aquém da esperada.

Os resultados da análise de ligação para severidade dos sintomas foliares da PVR com os marcadores Satt163 e Satt354 não indicaram associações significativas $(P<0,005)$ pelo teste

$F$, porém, houve tendência de ligação fraca $(P=0,077$ e 0,084 , respectivamente, para cada marcador) com os QRLs da PVR, ambos explicando, individualmente, apenas cerca de $4 \%$ da variação fenotípica para a severidade dos sintomas foliares da PVR (Tabelas 23 e 24). Na Tabela 23 também estão apresentados os contrastes efetuados para testar os efeitos aditivos e de dominância de cada loco marcador. Embora nenhum dos efeitos tenha sido significativo, nota-se leve tendência a favor de efeitos aditivos para o marcador Satt163 e a favor de efeitos dominantes para Satt354. Adicionalmente, também se procedeu à análise de variância segundo o modelo fatorial (cada marcador constituindo um fator), a qual não demonstrou efeito significativo $(P<0,05)$ da interação entre os dois marcadores utilizados, evidenciando a ausência de epistasia entre os dois locos. A análise dos dados com o programa Mapmaker (Lincoln et al., 
1992) confirmou que os dois marcadores não estão ligados, conforme relatado nos trabalhos de lqbal et al. (2001) e Njiti et al. (2002), por pertencerem a grupos de ligação diferentes.

Para o marcador Satt163, as médias de severidade das classes genotípicas seguiram o esperado (Tabela 24), já que a cultivar Estrela apresentou os alelos marcadores de resistência, havendo tendência de diferença entre as classes, as quais indicaram que os alelos de resistência, provavelmente, sejam recessivos (Tabelas 24 e 25). Para o marcador Satt354, houve comportamento contrário ao esperado, pois as análises anteriores indicaram a presença dos alelos marcadores de resistência na cultivar Conquista (Tabela 22).

Torto et al. (1996), utilizando dois métodos de inoculação artificial (grãos de aveia e fubá+areia colonizados com o patógeno) e 40 RILs do cruzamento 'Forrest' x 'Essex', não observaram associação entre os marcadores ligados a QRLs da PVR em experimentos de campo e nos experimentos de casa de vegetação. Em análises posteriores, utilizando dez linhagens de cada extremo desta população em avaliação de campo, estes autores observaram que três marcadores moleculares RAPD (OC01 650 , OE02 ${ }_{1000}$ e OR10 400 ) ligados a QRLs da PVR nos experimentos de campo, também foram associados com algumas características de resistência na casa de vegetação; porém, os dois experimentos na casa de vegetação detectaram diferentes marcadores associados com a resistência a PVR, além de que, para os marcadores $\mathrm{OC01}_{650}$ (associado com peso seco da parte aérea) e OE02 ${ }_{1000}$ (associado com peso seco de raízes e da parte aérea), os alelos marcadores favoráveis na casa de vegetação foram o oposto daqueles observados no campo. Os autores atribuíram estas diferenças à falta de associação entre os resultados da avaliação fenotípica a campo e em casa de vegetação, além da possibilidade de se detectar, nesta última, caracteres ligados à resistência a PVR e que não foram avaliados nos experimentos de campo, nos quais se avaliaram apenas a incidência e severidade dos sintomas foliares.

Com relação à eficiência da seleção a uxiliada por marcadores moleculares, em comparação com a seleção fenotípica, ambos marcadores apresentaram valores semelhantes, respectivamente, 50,8\% e 52\% (Tabela 25). Para o cálculo destes valores, levou-se em consideração a porcentagem de indivíduos considerados resistentes pela avaliação fenotípica e pela avaliação com o marcador molecular, em relação ao total de indivíduos considerados e, depois, fez-se o mesmo com os indivíduos suscetíveis, somando-se os dois valores de porcentagem obtidos para se obter a eficiência de seleção. No entanto, estas porcentagens de eficiência de seleção somente serão confiáveis se a avaliação fenotípica for realizada com segurança e se os marcadores moleculares utilizados realmente estiverem ligados, de preferência fortemente, aos QRLs da PVR. Neste sentido, Prabhu et al. (1999), após verificarem pela análise de ligação que o marcador Satt038 estava fortemente associado $(P=0,0001$, $r^{2}=28,0 \%$ ) com a severidade de infecção da PVR nas raízes, em RILs do cruzamento 'Flyer' $x$ 
'Hartwig', obtiveram 78\% de eficiência na seleção utilizando apenas este marcador molecular, quando a média do genitor resistente ('Hartwig') foi utilizada como ponto de corte na seleção fenotípica.

Com certeza, a precisão da avaliação fenotípica, por se estar trabalhando apenas com a geração $F_{2}$ (em vez de "genotipar" plantas $F_{2}$ e fazer a avaliação fenotípica em suas progênies $F_{3: 2}$ ), seja uma das principais explicações para os resultados encontrados. Isto porque, pelo efeito de ambiente (no qual também se incluem a variação na intensidade do inóculo e outras limitações do método de inoculação), um número elevado de plantas dos genitores, comprovadamente suscetíveis, se comportaram como resistentes (escapes), o mesmo ocorrendo nos cruzamentos (Apêndice 5). Assim, pelo grande efeito de ambiente sobre a manifestação dos sintomas foliares da PVR, talvez fosse necessária a avaliação de mais algumas dezenas ou centenas de plantas $F_{2}$, ou famílias $F_{3: 2}$, para se chegar a conclusões mais seguras e se certificar da ausência de ligação entre os marcadores utilizados e os respectivos QRLs da PVR no cruzamento avaliado. Segundo Lande \& Thompson (1990), o número necessário de indivíduos a serem avaliados para se detectar uma fração substancial da variância genética aditiva associada com um loco marcador molecular pode ser tão grande quanto centenas ou milhares, dependendo da herdabilidade do caráter e do número de QTLs que contribuem para a variância genética aditiva. Outro fator que também influencia na determinação do número adequado de indivíduos a ser analisado é o tipo de delineamento genético que se está utilizando (plantas $F_{2}$, famílias $F_{3: 2}$, retrocruzamentos, RILs, NILs ou linhagens dihaplóides).

Além disso, com exceção de Satt163, os marcadores utilizados foram associados à incidência da doença e não à severidade, durante a análise de ligação efetuada para a sua detecção, além de terem sido utilizados dados de vários experimentos de campo com RILs (Iqbal et al., 2001; Njiti et al.; 2002). Cumpre salientar também que o marcador Satt163 foi utilizado no lugar de Satt214, segundo recomendação de lqbal (2002), por não se dispor da seqüência de Satt214, mas no trabalho de lqbal et al. (2001) este foi mapeado a 11,8 cM de Satt214 e, embora citado que o QRL desta região estava contido no intervalo entre estes dois marcadores, nada foi citado sobre a ligação de Satt163 com este QRL. Porém, Njiti et al. (2002), os quais utilizaram RILs do cruzamento 'Pyramid' x 'Douglas', concluíram que Satt163 estava fortemente ligado $\left(P=0,0005,{ }^{2}=16,0 \%\right)$ a um dos QRLs da PVR no grupo de ligação $G$. Neste trabalho, os autores também encontraram que os marcadores Satt038 e Satt309, localizados a 2,2 e 7,6 cM, respectivamente, de Satt163, foram fracamente associados com a incidência da PVR ( $P=0,0011$ e $P=0,007$, respectivamente). Já lqbal et al. (2001) encontraram que Satt309 foi fortemente associado com o índice de doença da PVR ( $\left.P=0,0001, r^{2}=16,3 \%\right)$ e foi localizado a 10,7 cM de Satt163. Njiti et al. (2002) também encontraram que o marcador 
Satt307 (grupo de ligação C2) foi fortemente associado com a incidência da PVR ( $P=0,0008, r^{2}=$ 13,6\%), estando localizado a 86,6 cM distante de Satt371, o qual foi associado significativamente $\left(P=0,0019, r^{2}=12,0 \%\right)$ ao índice de doença da PVR no trabalho de lqbal et al. (2001). Njiti et al. (2002) também detectaram um marcador microssatélite no grupo de ligação $N$ (Satt080), o qual foi fortemente associado $\left(P=0,0009, P^{2}=15,6 \%\right)$ com a incidência da PVR e atribuído como sendo ligado ao mesmo QRL relatado anteriormente por Hnetkovsky et al. (1996), os quais trabalharam com marcadores RAPD em RILs do cruzamento 'Forrest' $x$ 'Essex'. Porém, Iqbal et al. (2001) trabalhando com a mesma população, relataram que este loco marcador do grupo de ligação $\mathrm{N}$ não foi relacionado com a resistência a PVR.

Estes resultados demonstram a dificuldade da utilização generalizada, nos programas de melhoramento, dos marcadores moleculares associados a QRLs da PVR já detectados. Em resumo, uma das principais dificuldades a serem superadas é a presença de multialelismo entre as cultivares e linhagens, o que pode gerar muitas dúvidas na interpretação dos resultados, mesmo em géis de poliacrilamida, conforme constatado no presente trabalho. Isto porque, além dos alelos (bandas) reconhecidamente responsáveis pela resistência ou suscetibilidade, podem surgir muitos outros, cuja associação com o efeito fenotípico do caráter pode não ser conhecida ou, ainda, não representar a variabilidade alélica dos locos do caráter em questão. Neste sentido, segundo Rongwen et al. (1995) já foram descritos locos microssatélites com até 26 alelos em estudo com 96 genótipos de soja. Toda esta diversidade é praticamente impossível de ser encontrada em locos controladores de caracteres que se expressam fenotipicamente. Outra grande dificuldade é a variação na distância estimada, em centimorgans, entre o loco do marcador molecular e do QRL propriamente dito, a qual pode variar grandemente entre diferentes genótipos, como conseqüência de recombinações ou de mutações, diminuindo a eficiência da seleção com base nos marcadores pela ocorrência de recombinação entre o loco do marcador e do QRL. Como a detecção e localização de QRLs é baseada em uma análise estatística, a utilização de diferentes métodos e bases de dados, assim como a exposição a diferentes erros, são outros fatores que também podem contribuir para a variação nos resultados, principalmente, nas estimativas das distâncias entre marcadores e QRLs e na quantificação dos efeitos estimados de cada loco. Desta forma, estas dificuldades somente serão totalmente superadas quando os genes de resistência a PVR forem clonados e passarem a ser sintetizados marcadores moleculares com base na seqüência dos próprios genes, o que deve ser conseguido num futuro muito próximo, pois de acordo com Triwitayakorn et al. (2002), três genes (Rfs1, Rfs2 e Rfs6) localizados no grupo de ligação G já foram seqüenciados, sendo os próximos os genes Rfs4 e Rfs5, respectivamente, dos grupos de ligação C2 e I, faltando apenas outros dois dos sete já relatados. 


\subsection{Considerações gerais}

Pelas condições e resultados dos testes de inoculação e dos três experimentos com a geração $F_{2}$, pode-se dizer que cada um constituiu um ambiente bastante distinto dos demais, sendo esta, provavelmente, a principal causa ch grande variação nos resultados obtidos entre experimentos. As diferenças entre os ambientes foram devidas, provavelmente, aos seguintes fatores: local de instalação (telado e casa de vegetação sem ou com "aluminet"), época de semeadura (associada com as temperaturas do ar e do solo), quantidade de inóculo (resultante do número de esporos presentes nos grãos de sorgo, número de grãos de sorgo utilizados por cova e posição dos grãos de sorgo em relação à sementes de soja), tipo de solo (esterilizado ou não e textura e fertilidade) e teor de umidade do solo (aplicação de estresse hídrico ou solo mantido próximo da capacidade de campo).

Dentre os experimentos com a geração $F_{2}$, os melhores resultados foram obtidos na casa de vegetação em 2002 (CV-JUL02), provavelmente, pelas condições mais favoráveis ao desenvolvimento do patógeno e para a manifestação dos sintomas foliares da doença, principalmente pela maior umidade do solo, associada com temperaturas amenas, além de que a colocação das sementes de soja em contato direto com o inóculo pode ter ajudado no aumento da severidade dos sintomas. Por outro lado, a colocação de mais dois grãos de sorgo colonizados com o patógeno na base de cada planta, aos 13 dias após a emergência, pareceu não ter contribuído para o agravamento dos sintomas foliares da doença, pois o período transcorrido até a última avaliação, efetuada aos 37 dias após a emergência, foi relativamente curto. De acordo com Gásperi (2000), a inoculação de grãos de sorgo colonizados com o patógeno, na região do colo de cada planta, no estádio V2, não foi o suficiente para a manifestação de sintomas foliares típicos da PVR na parte aérea das plantas, após 30 dias da inoculação; todavia provocou sintomas no sistema radicular, o qual foi então utilizado para a avaliação da resistência das cultivares.

Apesar das limitações do método dos grãos de sorgo colonizados com o patógeno para a inoculação artificial, principalmente no que se refere à uniformidade da quantidade de inóculo aplicada, a avaliação de um grande número de plantas de cada tratamento permitiu a discriminação dos genótipos com razoável segurança. Desse modo, com exceção da cultivar IAC-4, as demais cultivares que participaram do dialelo $5 \times 5$ apresentaram comportamento bastante estável, aumentando a segurança da metodologia utilizada.

Além das limitações do método de inoculação, outra grande dificuldade observada foi relacionada com a precisão das avaliações dos sintomas foliares, apesar de ter sido utilizada uma escala de notas de 1 a 5 , na qual se procurou minimizar o máximo possível a subjetividade por parte do avaliador, principalmente, pela consideração apenas do folíolo com os sintomas 
mais intensos. Porém, mesmo assim, as dificuldades começam a aparecer quando houver grande variação na manifestação dos sintomas foliares dentro de uma mesma planta, agravando-se ainda mais se este fato estiver associado com a queda prematura do folíolo mais afetado, o que faz com que o aspecto geral da planta deva ser preferido para as avaliações. A necessidade de se utilizar valores intermediários na escala também representou outra dificuldade em certas situações, mas permitiu maior flexibilidade quando se considerou o aspecto geral da planta. Especificamente quanto à nota 1,5, æ̀s vezes, foi difícil concluir se determinado sintoma era realmente o início da manifestação da doença ou não, por não ser muito típico, havendo casos, também, de diminuição da nota em avaliações posteriores, por ocorrer recuperação da planta, a qual, em alguns casos, deveu-se à emissão de folhas novas, sem sintomas da doença, aumentando a proporção de folhas sadias. No experimento da casa de vegetação em 2002 (CV-JUL02), para esclarecer certas dúvidas, em dois tratamentos foi realizada a análise de macro e micronutrientes de folhas aparentemente normais (cruzamento 'Conquista' x 'Cristalina') e daquelas duvidosas (cultivar Forrest), sendo constatada diminuição dos teores de $\mathrm{N}$ e $\mathrm{S}$ e aumento dos teores de $\mathrm{Ca}, \mathrm{B}, \mathrm{Mn}$ e $\mathrm{Zn}$ nestas últimas (vide apêndices), as quais também podem ser devidas a diferenças varietais, não sendo possível uma maior associação com os sintomas apresentados, além da presença de clorose leve em plantas da cultivar Forrest. Outra observação que levantou dúvidas foi o encarquilhamento inicial dos folíolos, o qual, posteriormente, conduziu a sintomas típicos da PVR ("folha carijó") nas plantas mais suscetíveis, sendo descartada a presença de viroses, pois sempre se procedeu ao controle de tripes e mosca branca.

Com relação às diferenças encontradas nos resultados da análise dia lélica de JinksHayman entre os três experimentos com a geração $F_{2}$, ficou comprovada, uma vez mais, a grande influência do ambiente sobre o controle da resistência a PVR, quando esta for avaliada pela manifestação dos sintomas foliares e sob condições de inoculação artificial. Como as maiores contradições foram observadas no experimento conduzido no telado, pode ser que isto tenha sido conseqüência do desenvolvimento diferenciado das plantas neste ambiente, as quais apresentaram intenso estiolamento e redução no tamanho das folhas, além de desenvolvimento geral mais lento, em comparação aos experimentos em casa de vegetação, nos quais o desenvolvimento das plantas foi bastante semelhante ao de experimentos de campo. Além disso, também como conseqüência de ser um ambiente mais sombreado, a necessidade de irrigação nas plantas do telado foi bem menor que na casa de vegetação, indicando menor demanda hídrica e também menor evapotranspiração no telado. Dessa forma, pode ser que todos estes fatores tenham contribuído para reduzir a translocação de toxina, produzida pelo fungo instalado no sistema radicular, para a parte aérea das plantas, alterando o seu comportamento frente à presença do patógeno. Isto porque, nos experimentos com inoculação 
artificial se compara, principalmente, a reação dos genótipos de soja à toxina produzida pelo fungo, o qual também deve ser o mecanismo de resistência primário no campo (Rupe, 1999). Apesar do mecanismo de resistência ser desconhecido, este pode estar relacionado com a redução no acúmulo da toxina ou na sua translocação, destoxificação ou, ainda, à combinação destes e de outros fatores (Hartman et al., 1997), sendo também necessário o conhecimento das condições que favorecem a produção da toxina e como os fatores ambientais, fisiológicos e bioquímicos influenciam o movimento da toxina e o potencial de degradação das plantas (Huang \& Hartman, 1998).

Por outro lado, a expressão dos sintomas foliares da PVR também deve estar relacionada com o grau de destruição do sistema radicular das plantas infectadas, prejudicando a absorção de água e nutrientes e também sua posterior translocação para a parte aérea, pelos danos causados ao sistema vascular na parte inferior das plantas. Neste sentido, uma constatação interessante ocorreu no experimento do telado (TE-JUL01): após se fazer a segunda e última avaliação dos sintomas foliares da PVR, aos 40 dias após a emergência, foram arrancadas várias plantas dos genitores suscetíveis ('Cristalina' e 'Estrela'), assim como de seu cruzamento, as quais haviam recebido nota um (ausência de sintomas foliares da doença). Notou-se que a raiz principal destas plantas estava totalmente necrosada desde a coifa até um certo ponto, a partir do qual tinha ocorrido intensa emissão de raízes secundárias, as quais se apresentavam sadias e com intenso desenvolvimento e, provavelmente, permitiram que as plantas tolerassem a presença do patógeno sem manifestar nenhum sintoma foliar da doença. Dessa forma, posteriormente, se concluiu que esta era uma das limitações do método de inoculação com os grãos de sorgo, devendo-se tomar o cuidado de não colocá-los muito profundamente no solo. Com isso, a profundidade das covas foi diminuída para $4 \mathrm{~cm}$ no experimento da casa de vegetação em 2002 (CV-JUL02).

Quanto ao comportamento das cultivares utilizadas no dialelo $5 \times 5$, chamou atenção a instabilidade apresentada por 'IAC-4', tanto nas avaliações dos seus sintomas foliares (Tabelas 4 e 5 e Apêndices 8, 9 e 10) como na ordem decrescente de dominância (Tabela 19). $O$ comportamento instável de determinadas cultivares quanto à reação a PVR, em diferentes experimentos, também é comentado por outros autores, entre eles Rupe et al. (1991) e Njiti et al. (1996), sendo constatada também a presença de interação genótipos $x$ ambientes significativa (Rupe \& Gbur, 1995; Njiti et al., 1996 e 1997a). Desta forma, recomendou-se a avaliação em mais de um local e ano (Rupe et al., 1991; Njiti et al., 1996). Pelo número de alelos marcadores de resistência apresentado na análise com os seis marcadores moleculares utilizados (Tabela 22) e supondo-se que eles representem a realidade, apesar da dúvida com o marcador Satt309, é mais provável que 'IAC-4' se comporte mais como suscetível do que como resistente, se não existirem mais alelos de resistência no seu genoma. Porém, fica difícil 
concluir que 'IAC-4' apresente mais alelos recessivos que 'Estrela', conforme demonstrado na análise dialélica do experimento CV-JUL02 (Tabela 19). No entanto, 'IAC-4' parece ter comportamento semelhante a 'Ripley', segundo o teste de inoculação em que ambas participaram (Tabela 4) e, pela análise molecular, a principal diferença poderia ser os alelos marcadores de resistência de Satt309 (Tabela 22). Com isto, pode-se supor que 'Ripley' e 'IAC-4' apresentem mecanismos de resistência semelhantes, os quais seriam altamente dependentes da pressão de inóculo, podendo estar relacionado mais com a redução da taxa de infecção inicial do patógeno do que com a capacidade de degradação (destoxificação) da toxina produzida pelo fungo causador da PVR e/ou com o seu transporte para a parte aérea. Segundo Njiti et al. (1997a) e Luo et al. (1999), 'Ripley’ apresentou menor taxa de colonização das raízes pelo patógeno, característica do grupo de genótipos considerados resistentes, em comparação com o grupo dos suscetíveis; porém, utilizando inoculação artificial, Gray \& Achenbach (1996) também observaram comportamento instável para esta cultivar. Isto sugere que ambas as características (destoxificação e menor taxa de colonização) estariam presentes nos genótipos mais resistentes, enquanto que em 'Ripley' e 'IAC-4' a resistência poderia estar relacionada apenas com a taxa de colonização do patógeno. Assim, com uma pressão de inóculo maior, embora a taxa de colonização nestas duas cultivares possa ser menor que naquelas consideradas suscetíveis, poderá haver colonização em nível suficiente para permitir a translocação de uma grande quantidade de toxina para a parte aérea, a tal ponto de fazê-las se comportarem como suscetíveis a PVR pela avaliação apenas dos sintomas foliares.

As hipóteses anteriores são corroboradas pelos resultados do experimento CV-JUL02, pois os cruzamentos de 'IAC-4' com 'Forrest' e 'Conquista' apresentaram as menores médias de severidade (SF e SP) e índice de doença (IDF e IDP) dos sintomas foliares da PVR (Apêndice 10). Além disso, para estas variáveis, observou-se diferença significativa para o contraste ('Conquista'x'Cristalina' + 'Conquista'x'Estrela') vs. ('Conquista'x'IAC-4') e altamente significativa $(P<0,01)$ para 0 contraste ('Forrest'x'Cristalina' + 'Forrest'x'Estrela') vs. ('Forrest'x'IAC-4'), sendo um indicativo de combinações alélicas mais favoráveis dos genitores resistentes com 'IAC-4' do que com as duas cultivares suscetíveis, além de sugerir que 'Forrest' x 'IAC-4' seria o melhor cruzamento. Fazendo-se inferências considerando apenas os seis locos da análise molecular (Tabela 22) e a resistência controlada por genes dominantes, embora o cruzamento 'Forrest' $x$ 'Conquista' pudesse originar os indivíduos transgressivos mais resistentes a PVR, os quais apresentariam os alelos de resistência dos QRLs ligados aos marcadores Satt163, Satt309, Satt354, Satt570 e OPE02 ${ }_{1000}$, a menor média de sintomas foliares da PVR, independentemente do efeito de cada $Q R L$, seria esperada no cruzamento 'Forrest' x 'IAC-4', por este apresentar fixado os alelos de resistência dos QRLs ligados a Satt163 e OPE02 ${ }_{1000}$ e, talvez, a Satt309, tendência esta observada no experimento CV-JUL02. 
Com base na análise molecular das cultivares também é possível se especular sobre o atendimento ou não das restrições impostas à utilização da análise dialélica de Jinks -Hayman. Pelos resultados da Tabela 22, se os marcadores moleculares representam a diversidade alélica existente nos locos que controlam a resistência a PVR, fica comprovada a presença de multialelismo e o não-atendimento desta restrição. Com relação à distribuição de genes independente nos genitores, mesmo que um dos genitores de 'Estrela' seja uma linhagem irmã de 'Cristalina', ambas não apresentaram os mesmos alelos marcadores de resistência e nem os mesmos alelos marcadores de suscetibilidade, embora, para estes últimos, isto possa ser questionado por causa do multialelismo. Já entre 'Cristalina' e 'Conquista', as duas apresentaram os alelos marcadores de resistência de Satt354, mas não é possível dizer se a presença destes alelos se deve ao provável ancestral em comum 'Davis', pois não se dispõe da análise molecular deste.

Comparando-se os resultados da análise dialélica do experimento TE-JUL01 com os resultados da análise de ligação utilizando os marcadores Satt163 e Satt354 e as plantas do cruzamento 'Conquista' $x$ 'Estrela' do mesmo experimento, observa-se que as tendências foram semelhantes, pois em ambas análises houve indícios de que os genes de resistência seriam recessivos (Tabelas 19 e 25). Porém, este resultado foi contrário ao observado nos outros dois experimentos (CV-SET01 e CV-JUL02), nos quais houve evidências de que o controle da resistência a PVR seria efetuado por genes predominantemente dominantes (Tabelas 19), embora exista a possibilidade de que um ou mais locos apresentem alelos de resistência recessivos, visto que foram também detectados efeitos aditivos dos genes (Tabelas 15, 16, 17 e 18) e a relação entre alelos favoráveis e dominância ( $r$ ), em nenhum dos casos, foi igual a 1,0 (Tabela 19). Além disso, o número mínimo de locos ou blocos gênicos que exibiram dominância, apesar de subestimado, esteve entre dois e três, mas se sabe que existem, pelo menos, sete locos já relatados que participam do controle da resistência a PVR e, segundo a análise molecular, pelo menos cinco genes de resistência estariam presentes nos cinco genitores utilizados no dialelo, sendo quatro encontrados em 'Forrest' e outro em 'Conquista' e 'Cristalina' (Tabela 22). Porém, ainda há outro encontrado em 'Forrest', segundo Hnetkovsky et al. (1996) e Njiti et al. (2002), totalizando pelo menos seis genes de resistência presentes nos genitores.

De qualquer forma, em resumo, conclui-se que a resistência a PVR foi herdada quantitativamente, sendo do tipo incompleta e, apesar dos efeitos aditivos dos genes também estarem presentes, os efeitos de dominância se manifestaram em proporção muito maior, havendo também elevado efeito de ambiente. Isto sugere que a seleção de genótipos mais resistentes a PVR deve ser efetuada em gerações avançadas de autofecundação, a exemplo de outros caracteres quantitativos quando, em conseqüência da maior homozigose, se 
acumulam os efeitos aditivos dos genes e se estabilizam as interações entre alelos (efeitos de dominância) e genes (efeitos epistáticos) distintos. Além disso, pelas dificuldades e pelos custos da avaliação da resistência a PVR, sugere-se que esta seja feita somente nas linhagens mais promissoras para outras características agronômicas de interesse e, de preferência, em vários ambientes ou utilizando-se a associação de metodologias (avaliação a campo, inoculação artificial e marcadores moleculares) para garantir maiores chances de sucesso no desenvolvimento de cultivares mais resistentes a PVR.

\subsection{Estratégias para a utilização da inoculação com grãos de sorgo colonizados com o patógeno para avaliação da resistência da soja a PVR}

Diante das condições em que foram realizados os diferentes testes e experimentos e pelos resultados obtidos, sugere-se que as condições mais adequadas para a obtenção de melhores resultados com a utilização do método de inoculação com grãos de sorgo colonizados com o patógeno seriam as seguintes:

- Semeadura em casa de vegetação no período do outono-inverno ou quando as temperaturas mínimas do solo, no interior dos vasos, não forem inferiores a $10^{\circ} \mathrm{C}$ e nem superiores a $25^{\circ} \mathrm{C}$ (de preferência, entre 15 a $20^{\circ} \mathrm{C}$ ) e com temperaturas máximas do ar na casa de vegetação de $30^{\circ} \mathrm{C}$ (de preferência, $28^{\circ} \mathrm{C}$ ). Se necessário, utilizar sombrite externo tipo "aluminet";

- Semeadura em vasos de cerâmica com perfuração no fundo, para evitar encharcamento do solo, e colocados sobre pratos plásticos, para manter a umidade do solo mais uniforme e também para evitar a disseminação de solo contaminado com Fusarium. Estes vasos podem ser com capacidade para 3,0 L de solo, para a condução de quatro ou cinco plantas (talvez apenas três plantas seja melhor se os sintomas foliares demorarem mais para se manifestar), ou com $0,5 \mathrm{~L}$ (ou 1,0 L) de solo, para a condução de plantas individuais e/ou para a avaliação dos sintomas radiculares;

- De preferência, o solo a ser utilizado deve ser esterilizado, de forma a evitar a presença de outros patógenos de solo, principalmente dos gêneros Rhizoctonia e Pythium, ou de antagônicos, como Trichoderma. No entanto, se o solo a ser utilizado for reconhecidamente livre destes fungos, pode-se então utilizá-lo diretamente;

- A abertura das covas deve ser feita com o solo úmido ou quase encharcado, podendo ser utilizado um bastão de madeira, o qual pode ser com a ponta recoberta por metal (como o do "kit" de jardinagem Tramontina), para diminuir a aderência de solo e facilitar a sua limpeza (apenas agitação em balde com água) entre um vaso e outro, ou quando necessário, de forma 
a manter a dimensão das covas uniforme. As covas devem ter cerca de $3,0 \mathrm{~cm}$ de profundidade (no máximo $4,0 \mathrm{~cm}$ ), principalmente, para evitar que as plantas venham emitir um grande número de raízes secundárias acima da região lesionada da raiz principal e passem a suportar melhor a presença do patógeno, ou seja, evitando-se que plantas suscetíveis se comportem como resistentes;

- Utilizar cinco grãos de sorgo colonizados com o patógeno por cova e colocá-los cerca de $1,0 \mathrm{~cm}$ abaixo das sementes de soja (duas por cova), de forma a garantir quantidade suficiente de inóculo e que as raízes das plântulas entrem em contato com o patógeno, evitando-se o contato direto deste com as sementes em germinação, o que também causaria lesões precoces na parte aérea (hipocótilo e cotilédones). Os grãos de sorgo devem estar cobertos com boa quantidade de macroconídios, de preferência com coloração tendendo para azul claro, devendo-se evitar aqueles grãos com cobertura muito desuniforme, grudados uns nos outros ou com coloração do micélio apenas branca ou tendendo para rosa;

- A umidade do solo deve ser mantida elevada (próxima da capacidade de campo), de forma a nunca permitir o seu ressecamento. A aplicação de um estresse hídrico nas plantas, cerca de 15 dias após a emergência, diminuindo as irrigações, acentuou a severidade dos sintomas, nos dias seguintes ao estresse, nas plantas que já manifestavam os sintomas da doença na parte aérea, mas pareceu evitar a progressão dos sintomas nas demais plantas;

- Para a avaliação das plantas sugere-se a observação dos sintomas foliares da PVR, em plantas individuais, utilizando-se a escala de severidade com notas de um a cinco apresentada no presente trabalho. De forma a se obter melhor discriminação entre os genótipos, podem ser efetuadas avaliações semanais, ou a cada dez dias, iniciando-se aos 20 dias após a emergência, e depois utilizar a época de avaliação com resultados mais contrastantes. Além da média de severidade, a variância de cada genótipo (com base em plantas individuais) pode ser uma variável auxiliar na discriminação dos genótipos mais resistentes a PVR, ou seja, aqueles com menor variância;

- Pela grande variação observada dentro dos tratamentos, sugere-se a avaliação de um grande número de plantas, no mínimo 20 de cada genótipo e, se possível, distribuídas em mais do que quatro repetições. 


\section{CONCLUSÕES}

a) A reação a PVR, avaliada pelos sintomas foliares, mostrou herança quantitativa, com forte influência do ambiente;

b) Estimou-se um número mínimo de três genes de resistência, os quais obedeceram a um modelo aditivo-dominante, com maior importância de efeitos dominantes (sobredominância, dominância e recessividade);

c) Os marcadores moleculares microssatélites evidenciaram a presença de multialelismo e de cinco genes de resistência no dialelo: quatro genes presentes em 'Forrest' e um gene em 'Conquista' e 'Cristalina';

d) No cruzamento 'Conquista' x 'Estrela' os marcadores Satt163 e Satt354 mostraram tendências de ligação com alelos recessivos de QRLs;

e) A cultivar IAC-4, tida como resistente ou moderadamente resistente, apresentou comportamento instável, enquanto que as cultivares Forrest e Conquista confirmaram sua maior resistência a PVR e, as cultivares Cristalina e Estrela, a sua maior suscetibilidade;

f) As cultivares Conquista e Forrest demonstraram serem boas fontes de resistência a PVR, tendo comportamento relativamente estável, enquanto a cultivar IAC-4 precisa ser melhor avaliada, pois deve conter QRLs de interesse;

g) O método dos grãos de sorgo colonizados com o patógeno foi relativamente eficiente para a discriminação do nível de resistência dos genótipos a PVR;

h) A incidência da doença não se mostrou adequada para a discriminação do nível de resistência dos diferentes genótipos avaliados em telado e casa de vegetação. 
ANEXOS 
Tabela 1. Referências a marcadores moleculares associados à reação a PVR em soja encontradas na literatura.

\begin{tabular}{|c|c|c|c|c|}
\hline \multirow[b]{2}{*}{ Referência } & \multirow{2}{*}{$\begin{array}{l}\text { Tipo de } \\
\text { Marcador }\end{array}$} & \multirow{2}{*}{$\begin{array}{c}\text { Denominação } \\
\text { do Marcador }\end{array}$} & \multicolumn{2}{|c|}{ Associação } \\
\hline & & & Característica $^{1}$ & $r^{2 *}$ \\
\hline \multirow[t]{8}{*}{ Chang et al. (1996) } & RAPD & $\mathrm{OIO}_{450}$ & DI e DS & 20 e 12 \\
\hline & RAPD & OE04450 & DI e DS & 16 e 20 \\
\hline & RAPD & OE02 ${ }_{1000}$ & DI e DS & 10 e 12 \\
\hline & RAPD & OG13490 & DI e DS & 17 e 10 \\
\hline & RAPD & $0005_{250}$ & DI & 13 \\
\hline & RAPD & OC01650 & DI & 16 \\
\hline & RFLP & Bng122D-1 & DS & 12 \\
\hline & RFLP & K455D-1 & $\mathrm{DI}$ & 16 \\
\hline \multirow[t]{4}{*}{ Hnetkovsky et al. (1996) } & RAPD & 0005250 & $\mathrm{DI}$ & 26 \\
\hline & RAPD & OC01650 & DI e DS & 30 e 28 \\
\hline & RAPD & OF04 1600 & DI & 19 \\
\hline & RFLP & K455D-1 & DI & 22 \\
\hline \multirow[t]{5}{*}{ Torto et al. (1996) } & RAPD & $0019_{400}$ & altura da planta & 35 \\
\hline & RAPD & $0019_{400}$ & M.S. parte aérea & 20 \\
\hline & RAPD & OE02 1000 & M.S. raízes & 81 \\
\hline & RAPD & OE02 ${ }_{1000}$ & M.S. parte aérea & 71 \\
\hline & RAPD & OC01650 & M.S. parte aérea & 44 \\
\hline Chang et al. (1997) & RAPD & $\mathrm{OIO3}_{450}$ & DI & 20 \\
\hline Doubler et al. (1997) & RAPD e RFLP & Ol03450 e Bng122D & DX & 38 \\
\hline Prabhu et al. (1997) & RAPD & $\mathrm{O} 03_{512}$ & - & - \\
\hline Bell-Johnson et al. (1998) & $\begin{array}{c}\text { microssatélite } \\
\text { (SSR) }\end{array}$ & $\begin{array}{c}\text { Satt038, } 163,214 \\
275 \text { e } 309\end{array}$ & - & - \\
\hline Njiti et al. (1998a) & RAPD e RFLP & Ol03512 e Bng122D-1 & DXe IS & 38 e 47 \\
\hline \multirow[t]{5}{*}{ Meksem et al. (1999a) } & SSR & Satt 309 & $\mathrm{DX}$ & 25 e 63 \\
\hline & RAPD & Ol03512 & DX & 38 \\
\hline & RAPD & $\mathrm{OlO3}_{512}$ & IS & 39 e 47 \\
\hline & RFLP & Bng122D & $\mathrm{DX}$ & 32 e 38 \\
\hline & RFLP & Bng122D & IS & 38 e 73 \\
\hline Prabhu et al. (1999) & SSR & Satt038 & IS & 28 \\
\hline \multirow[t]{6}{*}{ Iqbal et al. (2001) } & RAPD & OE02 1000 & $\mathrm{DI}$ & 12,6 \\
\hline & SSR & Satt214 & DI & 24,1 \\
\hline & SSR & Satt309 & DI & 16,3 \\
\hline & SSR & Satt354 & DI & 11,5 \\
\hline & SSR & Satt371 & DI & 12,0 \\
\hline & SSR & Satt570 & $\mathrm{DI}$ & 19,2 \\
\hline \multirow[t]{3}{*}{ Njiti et al. (2002) } & SSR & Satt080 & DI & 15,6 \\
\hline & SSR & Satt163 & DI & 16,0 \\
\hline & SSR & Satt307 & $\mathrm{DI}$ & 13,6 \\
\hline
\end{tabular}

Porcentagem da variação fenotípica explicada pelo marcador pela análise de regressão.

${ }^{1} \mathrm{DI}=$ incidência da doença; $\mathrm{DS}=$ severidade da doença; $\mathrm{DX}=$ índice de doença = $(\mathrm{DIxDS}) / 9$; $I S=$ severidade de infecção nas raízes; M.S.= massa seca. 
Tabela 2. Esquema geral da análise de variância (ao nível de médias de parcelas) para a geração $F_{2}$ do dialelo $5 \times 5$, em blocos ao acaso e respectivas decomposições dos graus de liberdade.

\begin{tabular}{|c|c|c|c|c|}
\hline \multirow[b]{2}{*}{ Fontes de Variação } & \multirow[b]{2}{*}{ GL } & \multirow[b]{2}{*}{$\mathrm{QM}$} & \multicolumn{2}{|c|}{$F^{1}$} \\
\hline & & & Homogeneidade & Heterogeneidade \\
\hline Blocos (B) & B-1 & $Q_{1}$ & $\mathrm{Q}_{1} / \mathrm{Q}_{10}$ & $\mathrm{Q}_{1} / \mathrm{Q}_{10}$ \\
\hline Vasos (V) & $V-1$ & $\mathrm{Q}_{2}$ & $Q_{1} / Q_{10}$ & $Q_{1} / Q_{10}$ \\
\hline Genótipos (T) & $\mathrm{T}-1$ & $Q_{3}$ & $\mathrm{Q}_{1} / \mathrm{Q}_{10}$ & $\mathrm{Q}_{1} / \mathrm{Q}_{10}$ \\
\hline Genitores (G) & G-1 & $\mathrm{Q}_{4}$ & $\mathrm{Q}_{1} / \mathrm{Q}_{10}$ & $Q_{1} / Q_{11}$ \\
\hline Cruzamentos $F_{2}(C)$ & C-1 & $Q_{5}$ & $Q_{1} / Q_{10}$ & $\mathrm{Q}_{1} / \mathrm{Q}_{12}$ \\
\hline G vs. C & 1 & $\mathrm{Q}_{6}$ & $\mathrm{Q}_{1} / \mathrm{Q}_{10}$ & $\mathrm{Q}_{1} / \mathrm{Q}_{13}$ \\
\hline Vasos/Genótipos & $\left(V_{G-1}\right) G+\left(V_{C}-1\right) C$ & $Q_{7}$ & $\mathrm{Q}_{1} / \mathrm{Q}_{10}$ & $\mathrm{Q}_{1} / \mathrm{Q}_{10}$ \\
\hline Vasos/Genitores & $\left(V_{G-1}\right) G$ & $\mathrm{Q}_{8}$ & $\mathrm{Q}_{1} / \mathrm{Q}_{10}$ & $\mathrm{Q}_{1} / \mathrm{Q}_{11}$ \\
\hline Vasos/Cruzamentos $F_{2}$ & $\left(V_{C}-1\right) C$ & $Q_{9}$ & $\mathrm{Q}_{1} / \mathrm{Q}_{10}$ & $\mathrm{Q}_{1} / \mathrm{Q}_{12}$ \\
\hline Resíduo (Blocos x Vasos) & $(\mathrm{B}-1)(\mathrm{V}-1)$ & $Q_{10}$ & --- & --- \\
\hline Blocos x Vasos de Genitores & $(B-1)\left[\left(V_{G} G\right)-1\right]$ & $Q_{11}$ & --- & --- \\
\hline Blocos $\times$ Vasos de Cruzam. $F_{2}$ & $(\mathrm{~B}-1)\left[\left(\mathrm{V}_{\mathrm{C}} \mathrm{C}\right)-1\right]$ & $\mathrm{Q}_{12}$ & --- & --- \\
\hline Blocos x (VG vs. VC) & $B-1$ & $\mathrm{Q}_{13}$ & --- & --- \\
\hline (Resíduo Entre Parcelas) & {$\left[\left(V_{G}-1\right) G+\left(V_{C}-1\right) C+(B-1)(V-1)\right]$} & $\mathrm{Q}_{14}$ & --- & --- \\
\hline Total & {$\left[B\left(V_{G} G+V_{C} C\right)\right]-1$} & --- & --- & --- \\
\hline
\end{tabular}
resultados do teste de Bartlett para verificação da homogeneidade dos resíduos.

B, V, T, G e C: número de blocos, vasos (dentro de cada bloco), genótipos, genitores e cruzamentos $F_{2}$, respectivamente.

VG e VC: vasos de genitores e de cruzamentos $F_{2}$, respectivamente.

$V_{G}$ e $V_{C}$ : número de vasos dentro de genitores e de cruzamentos $F_{2}$, respectivamente. 
Tabela 3. Esquema geral da análise de variância (ao nível de médias de parcelas) para a geração $F_{2}$ do dialelo $5 \times 5$, no delineamento inteiramente ao acaso e respectivas decomposições dos graus de liberdade.

\begin{tabular}{|c|c|c|c|c|}
\hline \multirow[b]{2}{*}{ Fontes de Variação } & \multirow[b]{2}{*}{$\mathrm{GL}$} & \multirow[b]{2}{*}{ QM } & \multicolumn{2}{|c|}{$\mathrm{F}^{1}$} \\
\hline & & & Homogeneidade & Heterogeneidade \\
\hline Genótipos (T) & $\mathrm{T}-1$ & $Q_{1}$ & $Q_{1} / Q_{5}$ & $Q_{1} / Q_{5}$ \\
\hline Genitores (G) & G-1 & $\mathrm{Q}_{2}$ & $Q_{1} / Q_{5}$ & $Q_{1} / Q_{6}$ \\
\hline Cruzamentos $F_{2}(C)$ & C-1 & $\mathrm{Q}_{3}$ & $Q_{1} / Q_{5}$ & $Q_{1} / Q_{7}$ \\
\hline G vs. C & 1 & $\mathrm{Q}_{4}$ & $Q_{1} / Q_{5}$ & $Q_{1} / Q_{5}$ \\
\hline Resíduo & {$\left[\left(J_{G}-1\right) G+\left(J_{C}-1\right) C\right]$} & $Q_{5}$ & --- & --- \\
\hline Resíduo de Genitores & $\left(J_{G}-1\right) G$ & $\mathrm{Q}_{6}$ & --- & --- \\
\hline Resíduo de Cruzamentos $F_{2}$ & $\left(J_{C}-1\right) C$ & $\mathrm{Q}_{7}$ & --- & --- \\
\hline Total & {$\left[\left(J_{G} G+J_{C} C\right)\right]-1$} & --- & --- & --- \\
\hline \multicolumn{5}{|c|}{$\begin{array}{l}\text { Cada coluna corresponde, respectivamente, à forma de realização do teste } \mathrm{F} \text { após os } \\
\text { resultados do teste de Bartlett para verificação da homogeneidade dos resíduos. }\end{array}$} \\
\hline \multicolumn{5}{|c|}{ T, G e C: número de genótipos, genitores e cruzamentos $F_{2}$, respectivamente. } \\
\hline \multicolumn{5}{|c|}{$\mathrm{J}_{\mathrm{G}}$ e $\mathrm{J}_{\mathrm{C}}$ : número de repetições de genitores e de cruzamentos $\mathrm{F}_{2}$, respectivamente. } \\
\hline
\end{tabular}


Tabela 4. Avaliação preliminar da severidade (escala de 1 a 5) dos sintomas foliares da PVR, com base no folíolo com os sintomas mais intensos, em plantas individuais e severidade média (SM), incidência em porcentagem (IP) e índice de doença (ID), de oito cultivares de soja, em casa de vegetação, aos 21 dias após a emergência, utilizando-se inoculação com três ou seis grãos de sorgo/cova colonizados com o patógeno. Soja, Piracicaba-SP, semeadura em 19/06/2000.

\begin{tabular}{|c|c|c|c|c|c|c|c|c|c|c|c|c|c|c|c|c|c|c|c|}
\hline \multirow[b]{3}{*}{ Cultivar } & \multicolumn{8}{|c|}{ Três grãos de sorgo/cova } & \multicolumn{8}{|c|}{ Seis grãos de sorgo/cova } & \multirow{2}{*}{\multicolumn{3}{|c|}{ Média geral }} \\
\hline & \multicolumn{5}{|c|}{ Planta } & \multicolumn{3}{|c|}{ Média de vaso } & \multicolumn{5}{|c|}{ Planta } & \multicolumn{3}{|c|}{ Média de vaso } & & & \\
\hline & 1 & 2 & 3 & 4 & 5 & SM & IP & ID & 1 & 2 & 3 & 4 & 5 & SM & IP & ID & SM & $\mathrm{IP}$ & ID \\
\hline Conquista & 1,5 & 1,5 & 2,0 & 1,5 & 2,0 & 1,7 & 100 & 34,0 & 2,5 & 1,5 & 1,0 & 1,0 & 1,5 & 1,5 & 60 & 18,0 & 1,6 & 80 & 26,0 \\
\hline Cristalina & 3,0 & 2,0 & 2,0 & 2,0 & 3,0 & 2,4 & 100 & 48,0 & 4,0 & 2,0 & 4,0 & 2,0 & 4,0 & 3,2 & 100 & 64,0 & 2,8 & 100 & 56,0 \\
\hline Estrela & 2,0 & 2,0 & 3,0 & 2,5 & 2,0 & 2,3 & 100 & 46,0 & 4,0 & 2,0 & 4,0 & 3,0 & 2,5 & 3,1 & 100 & 62,0 & 2,7 & 100 & 54,0 \\
\hline Forrest & 1,5 & 1,0 & 2,0 & 2,0 & 1,5 & 1,6 & 80 & 25,6 & 1,0 & 2,5 & 2,0 & 2,0 & 2,0 & 1,9 & 80 & 30,4 & 1,7 & 80 & 28,0 \\
\hline IAC-4 & 4,0 & 3,0 & 2,0 & 1,5 & 3,5 & 2,8 & 100 & 56,0 & 3,0 & 3,0 & 1,5 & 1,5 & 4,0 & 2,6 & 100 & 52,0 & 2,7 & 100 & 54,0 \\
\hline IAC-8 & 3,0 & 1,5 & 2,0 & 1,5 & 1,0 & 1,8 & 80 & 28,8 & 2,0 & 2,5 & 2,0 & 2,0 & 2,0 & 2,1 & 100 & 42,0 & 1,9 & 90 & 35,4 \\
\hline Ripley & 4,0 & 5,0 & 2,0 & 2,0 & 2,0 & 3,0 & 100 & 60,0 & 3,5 & 4,0 & 4,0 & 3,5 & 1,5 & 3,3 & 100 & 66,0 & 3,1 & 100 & 63,0 \\
\hline SS-1 & 2,0 & 1,5 & 1,5 & 2,0 & 2,0 & 1,8 & 100 & 36,0 & 1,5 & 1,5 & 1,0 & 1,0 & 2,0 & 1,4 & 60 & 16,8 & 1,6 & 80 & 26,4 \\
\hline
\end{tabular}


Tabela 5. Severidade média (escala de 1 a 5) dos sintomas foliares da PVR, com base no aspecto geral da planta em quatro épocas, em teste de inoculação com nove cultivares de soja e dois métodos de inoculação (cinco grãos de sorgo/cova ou um grão de soja/cova colonizados com o patógeno), conduzido em telado. Soja, Piracicaba-SP, semeadura em 08/07/2002.

\begin{tabular}{|c|c|c|c|c|c|c|c|c|c|c|c|c|}
\hline \multirow[b]{3}{*}{ Cultivares } & \multicolumn{12}{|c|}{ Dias após a emergência } \\
\hline & \multicolumn{3}{|c|}{26} & \multicolumn{3}{|c|}{33} & \multicolumn{3}{|c|}{40} & \multicolumn{3}{|c|}{47} \\
\hline & Sorgo & Soja & Média & Sorgo & Soja & Média & Sorgo & Soja & Média & Sorgo & Soja & Média \\
\hline Conquista & $2,02 \mathrm{abA}$ & $1,04 \mathrm{~B}$ & 1,53 & 2,40 & 1,31 & 1,85 & 2,61 & 1,48 & 2,04 & 2,73 & 1,72 & 2,22 \\
\hline Cristalina & $1,64 \mathrm{a}$ & 1,36 & 1,50 & 2,16 & 1,56 & 1,86 & 2,32 & 1,56 & 1,94 & 2,66 & 1,71 & 2,18 \\
\hline Estrela & $1,67 \mathrm{a}$ & 1,28 & 1,47 & 1,97 & 1,88 & 1,92 & 2,15 & 1,90 & 2,02 & 2,40 & 2,13 & 2,26 \\
\hline Essex & $1,77 a b$ & 1,49 & 1,63 & 2,00 & 1,90 & 1,95 & 2,15 & 2,14 & 2,13 & 2,60 & 2,29 & 2,44 \\
\hline Forrest & $1,72 \quad b$ & 1,37 & 1,54 & 1,92 & 1,52 & 1,72 & 1,80 & 1,42 & 1,61 & 2,00 & 1,49 & 1,74 \\
\hline IAC-4 & $2,59 \mathrm{bA}$ & $1,37 \mathrm{~B}$ & 1,98 & 3,10 & 1,57 & 2,33 & 3,03 & 1,72 & 2,37 & 2,96 & 1,94 & 2,45 \\
\hline IAC-8 & $1,50 \mathrm{a}$ & 1,17 & 1,33 & 2,13 & 1,48 & 1,80 & 2,35 & 1,62 & 1,98 & 2,73 & 1,89 & 2,31 \\
\hline IAC-8-2 & $1,69 a$ & 1,71 & 1,70 & 2,42 & 2,19 & 2,30 & 2,73 & 2,09 & 2,41 & 3,13 & 2,48 & 2,80 \\
\hline SS-1 & $1,88 \mathrm{abA}$ & $1,16 \mathrm{~B}$ & 1,52 & 2,32 & 1,32 & 1,82 & 2,87 & 1,55 & 2,21 & 2,97 & 1,60 & 2,28 \\
\hline Média & 1,83 & 1,33 & 1,58 & $2,27 \mathrm{~A}$ & $1,64 \mathrm{~B}$ & 1,95 & $2,45 \mathrm{~A}$ & $1,72 \mathrm{~B}$ & 2,08 & $2,69 \mathrm{~A}$ & $1,92 \mathrm{~B}$ & 2,30 \\
\hline
\end{tabular}

Médias seguidas de letras diferentes, minúsculas nas colunas e maiúsculas nas linhas, dentro de uma mesma época, diferem entre si, a $5 \%$ de probabilidade, pelo teste de Tukey-Kramer. 
Tabela 6. Incidência em porcentagem e índice de doença dos sintomas foliares da PVR, com base no aspecto geral da planta em quatro épocas, em teste de inoculação com nove cultivares de soja e dois métodos de inoculação (cinco grãos de sorgo/cova ou um grão de soja/cova colonizados com o patógeno), conduzido em telado. Soja, Piracicaba-SP, semeadura em 08/07/2002.

\begin{tabular}{|c|c|c|c|c|c|c|c|c|c|c|c|c|c|}
\hline \multirow[b]{3}{*}{ Caráter } & \multirow[b]{3}{*}{ Cultivares } & \multicolumn{12}{|c|}{ Dias após a emergência } \\
\hline & & \multicolumn{3}{|c|}{26} & \multicolumn{3}{|c|}{33} & \multicolumn{3}{|c|}{40} & \multicolumn{3}{|c|}{47} \\
\hline & & Sorgo & Soja & Média & Sorgo & Soja & Média & Sorgo & Soja & Média & Sorgo & Soja & Média \\
\hline \multirow{10}{*}{ Incidência } & Conquista & 61,2 & 11,8 & 36,5 & $67,5 \mathrm{~A}$ & $24,3 \mathrm{ab} B$ & 45,9 & 72,5 & 23,3 & 47,9 & 66,2 & 22,6 & 44,4 \\
\hline & Cristalina & 48,7 & 37,5 & 43,1 & $70,0 \mathrm{~A}$ & $36,2 \mathrm{abcB}$ & 53,1 & 65,0 & 21,2 & 43,1 & 63,7 & 31,2 & 47,4 \\
\hline & Estrela & 60,0 & 25,0 & 42,5 & 85,0 & 93,7 & 89,3 & 85,0 & 75,0 & 80,0 & 90,0 & 75,0 & 82,5 \\
\hline & Essex & 51,2 & 43,7 & 47,4 & 73,7 & $75,4 a b c$ & 74,5 & 78,7 & 71,6 & 75,1 & 83,7 & 75,4 & 79,5 \\
\hline & Forrest & 60,0 & 50,0 & 55,0 & 75,0 & $78,7 \quad b c$ & 76,8 & 70,0 & 63,7 & 66,8 & 80,0 & 68,7 & 74,3 \\
\hline & IAC-4 & 78,7 & 37,5 & 58,1 & $90,0 \mathrm{~A}$ & $37,5 \mathrm{abcB}$ & 63,7 & 85,0 & 42,5 & 63,7 & 85,0 & 42,5 & 63,7 \\
\hline & IAC-8 & 42,9 & 20,9 & 31,9 & 93,8 & $58,3 \mathrm{abc}$ & 76,0 & 92,5 & 47,3 & 69,9 & 83,4 & 64,6 & 74,0 \\
\hline & IAC-8-2 & 55,8 & 70,0 & 62,9 & $83,7 \mathrm{~A}$ & $43,3 \mathrm{abcB}$ & 63,5 & 82,5 & 48,3 & 65,4 & 95,0 & 65,8 & 80,4 \\
\hline & SS-1 & 66,2 & 27,5 & 46,8 & $72,5 \mathrm{~A}$ & 20,0 a $\quad B$ & 46,2 & 82,5 & 30,0 & 56,2 & 87,5 & 30,0 & 58,7 \\
\hline & Média & $58,3 \mathrm{~A}$ & $36,0 \mathrm{~B}$ & 47,1 & 79,0 & 51,9 & 65,4 & $79,3 \mathrm{~A}$ & $47,0 \mathrm{~B}$ & 63,1 & $81,6 \mathrm{~A}$ & $52,9 \mathrm{~B}$ & 67,2 \\
\hline \multirow{10}{*}{$\begin{array}{c}\text { Índice de } \\
\text { Doença }\end{array}$} & Conquista & 26,9 & 1,4 & 14,1 & 36,6 & 7,0 & 21,8 & 41,2 & 8,4 & 24,8 & 38,7 & 9,7 & 24,2 \\
\hline & Cristalina & 17,9 & 10,7 & 14,3 & 33,9 & 12,3 & 23,1 & 32,5 & 9,7 & 21,1 & 38,4 & 12,9 & 25,6 \\
\hline & Estrela & 20,4 & 7,8 & 14,1 & 34,8 & 35,9 & 35,3 & 38,1 & 28,9 & 33,5 & 45,0 & 32,2 & 38,6 \\
\hline & Essex & 19,1 & 16,1 & 17,6 & 29,7 & 30,0 & 29,8 & 34,2 & 32,4 & 33,3 & 44,9 & 35,2 & 40,0 \\
\hline & Forrest & 21,0 & 14,3 & 17,6 & 29,0 & 23,9 & 26,4 & 25,4 & 19,1 & 22,2 & 32,8 & 21,2 & 27,0 \\
\hline & IAC-4 & 41,3 & 11,1 & 26,2 & 56,7 & 12,3 & 34,5 & 53,7 & 15,3 & 34,5 & 52,5 & 17,6 & 35,0 \\
\hline & IAC-8 & 16,3 & 5,1 & 10,7 & 40,5 & 17,7 & 29,1 & 44,8 & 17,6 & 31,2 & 48,7 & 24,7 & 36,7 \\
\hline & IAC-8-2 & 19,4 & 26,5 & 22,9 & 40,6 & 29,0 & 34,8 & 45,4 & 29,0 & 37,2 & 59,7 & 39,5 & 49,6 \\
\hline & SS-1 & 29,2 & 6,7 & 17,9 & 37,8 & 6,6 & 22,2 & 51,5 & 11,2 & 31,3 & 55,7 & 11,6 & 33,6 \\
\hline & Média & $23,5 \mathrm{~A}$ & $11,1 \mathrm{~B}$ & 17,3 & $37,7 \mathrm{~A}$ & $19,4 \mathrm{~B}$ & 28,6 & $40,8 \mathrm{~A}$ & $19,1 \mathrm{~B}$ & 29,9 & $46,3 \mathrm{~A}$ & $22,7 \mathrm{~B}$ & 34,5 \\
\hline
\end{tabular}

Médias seguidas de letras diferentes, minúsculas nas colunas e maiúsculas nas linhas, dentro de uma mesma época, diferem entre si, a $5 \%$ de probabilidade, pelo teste de Tukey-Kramer. 
Tabela 7. Análise de variância (média de cinco plantas/vaso) para sintomas radiculares (severidade= escala de 1 a 5 , e comprimento da lesão, em $\mathrm{mm}$ ) e foliares da PVR (severidade= escala de 1 a 5 , e índice de doença), na geração $F_{2}$ do dialelo $5 \times 5$ conduzido em telado (TE-JUL01). Soja, Piracicaba-SP.

\begin{tabular}{|c|c|c|c|c|c|c|}
\hline \multirow[b]{3}{*}{ Fontes de Variação } & \multirow[b]{3}{*}{$\mathrm{GL}$} & \multicolumn{2}{|c|}{ Quadrados Médios } & \multirow[b]{3}{*}{ GL } & \multicolumn{2}{|c|}{ Quadrados Médios } \\
\hline & & \multicolumn{2}{|c|}{ Sintomas Radiculares } & & \multicolumn{2}{|c|}{ Sintomas Foliares } \\
\hline & & Severidade & Comprimento Lesão $^{1}$ & & Severidade $^{1}$ & Índice de Doença \\
\hline Blocos & 4 & $0,7447^{*}$ & 0,7828 & 4 & $0,1147^{\star *}$ & $582,29^{*}$ \\
\hline Vasos & 69 & $0,4753^{\star *}$ & 0,4774 & 69 & 0,0330 & 251,23 \\
\hline Genótipos & 14 & $0,7309^{\star *}$ & 0,3729 & 14 & $0,0605^{\star *}$ & $420,53^{\star}$ \\
\hline Genitores (G) & 4 & 0,2190 & 0,3333 & 4 & $0,0775^{\star}$ & $557,38^{\star}$ \\
\hline Cruzamentos $F_{2}(C)$ & 9 & $0,9793^{\star *}$ & 0,4366 & 9 & $0,0585^{\star}$ & 402,13 \\
\hline G vs. C & 1 & 0,5601 & 0,0003 & 1 & 0,0106 & 38,73 \\
\hline Vasos/Genótipos & 55 & 0,4102 & 0,5041 & 55 & 0,0261 & 208,13 \\
\hline Vasos/Genitores & 5 & $0,7397^{\star}$ & 0,6807 & 5 & 0,0094 & 114,95 \\
\hline Vasos/Cruzamentos $F_{2}$ & 50 & 0,3771 & 0,4864 & 50 & 0,0277 & 217,45 \\
\hline Resíduo (Blocos x Vasos) & 272 & 0,3069 & 0,4470 & 276 & 0,0276 & 231,27 \\
\hline Blocos x Vasos de Genitores & 36 & 0,3839 & 0,3640 & 36 & 0,0355 & 294,21 \\
\hline Blocos $\times$ Vasos de Cruzamentos $F_{2}$ & 232 & 0,2914 & 0,4451 & 236 & 0,0266 & 224,69 \\
\hline Blocos x (Vasos de G vs. Vasos de C) & 4 & 0,5158 & 1,3043 & 4 & 0,0136 & 53,00 \\
\hline Total & 345 & --- & --- & 349 & --- & --- \\
\hline Qui-quadrado (teste de Bartlett) & --- & 1,89 & 4,10 & --- & 2,48 & 4,04 \\
\hline C.V. (\%) & --- & 25,1 & 24,3 & --- & 11,8 & 50,9 \\
\hline
\end{tabular}

${ }^{1}$ Dados transformados para $\sqrt{\mathrm{x}+0,5}$.

${ }^{*},{ }^{* \star}$ Significativo pelo teste $\mathrm{F}$ (ou qui-quadrado), a $5 \%$ e $1 \%$ de probabilidade, respectivamente. 
Tabela 8. Resumo da análise de variância (média de cinco plantas/vaso) de contrastes para sintomas radiculares (severidade= escala de 1 a 5, e comprimento da lesão, em $\mathrm{mm}$ ) e foliares da PVR (severidade= escala de 1 a 5 , e índice de doença), na geração $F_{2}$ do dialelo $5 \times 5$ conduzido em telado (TE-JUL01). Soja, Piracicaba-SP.

\begin{tabular}{|c|c|c|c|c|c|}
\hline \multirow[b]{3}{*}{ Contrastes Ortogonais } & \multirow[b]{3}{*}{$\mathrm{GL}$} & \multicolumn{4}{|c|}{ Quadrados Médios } \\
\hline & & \multicolumn{2}{|c|}{ Sintomas Radiculares } & \multicolumn{2}{|c|}{ Sintomas Foliares } \\
\hline & & Severidade & Comp. Lesão ${ }^{1}$ & Severidade $^{1}$ & Índice Doença \\
\hline Genitores vs. Cruzamentos $F_{2}$ & 1 & 0,5601 & 0,0003 & 0,0106 & 38,73 \\
\hline 'Forrest' vs. 'Conquista' & 1 & 0,1901 & 0,9595 & 0,0324 & 485,11 \\
\hline ('Forrest' + 'Conquista') vs. demais Genitores & 1 & 0,0031 & 0,1890 & $0,2489^{\star *}$ & $1616,11^{* *}$ \\
\hline ('Cristalina' + 'Estrela') vs. 'IAC-4' & 1 & 0,4788 & 0,0319 & 0,0260 & 15,00 \\
\hline 'Cristalina' vs. 'Estrela' & 1 & 0,2040 & 0,1526 & 0,0029 & 113,29 \\
\hline ('Conquista'x'Forrest') vs. demais Cruzamentos & 1 & 0,5479 & 0,1320 & $0,2840^{* *}$ & $1806,63^{\star *}$ \\
\hline Cruzamentos "Suscetíveis" vs. Cruzamentos "Resistentes" & 1 & 0,1207 & 0,0017 & 0,1029 & $925,12^{*}$ \\
\hline ('Cristalina'x'IAC-4' + 'Cristalina'x'Estrela') vs. ('IAC-4'x'Estrela') & 1 & $3,0027^{* *}$ & $2,5992^{* *}$ & 0,0200 & 235,53 \\
\hline ('Cristalina'X'IAC-4’) vs. ('Cristalina'X'Estrela') & 1 & 0,0871 & 0,0000 & 0,0312 & 61,81 \\
\hline $\begin{array}{l}\text { ('Conquista'x'Cristalina' + 'Conquista'x'IAC-4' + 'Conquista'x'Estrela') vs } \\
\text { ('Forrest'x'Cristalina' + 'Forrest'x'IAC-4' + 'Forrest'x'Estrela') }\end{array}$ & 1 & 0,4986 & 0,0372 & 0,0309 & 58,94 \\
\hline ('Conquista'x'Cristalina' + 'Conquista'x’Estrela') vs. ('Conquista'x'IAC-4') & 1 & $2,5833^{\star *}$ & 0,5344 & 0,0260 & 131,93 \\
\hline ('Conquista'x'Cristalina') vs. ('Conquista'x'Estrela') & 1 & 0,7216 & 0,1909 & 0,0123 & 68,91 \\
\hline ('Forrest'x'Cristalina' + 'Forrest'x'Estrela') vs. ('Forrest'x'IAC-4') & 1 & 0,1413 & 0,0394 & 0,0028 & 44,70 \\
\hline ('Forrest'x'Cristalina') vs. ('Forrest'x'Estrela') & 1 & 1,0935 & 0,3976 & 0,0160 & 285,58 \\
\hline
\end{tabular}

\footnotetext{
${ }^{1}$ Dados transformados para $\sqrt{\mathrm{x}+0,5}$.

*,** Significativo pelo teste $\mathrm{F}$, a $5 \%$ e $1 \%$ de probabilidade, respectivamente.
} 
Tabela 9. Análise de variância (média de cinco plantas/vaso) para sintomas foliares da PVR (severidade $=$ escala de 1 a 5 , e índice de doença), na geração $F_{2}$ do dialelo $5 \times 5$ conduzido em casa de vegetação (CV-SET01). Soja, Piracicaba-SP.

\begin{tabular}{|c|c|c|c|}
\hline \multirow[b]{2}{*}{ Fontes de Variação } & \multirow[b]{2}{*}{$\mathrm{GL}$} & \multicolumn{2}{|c|}{ Quadrados Médios } \\
\hline & & Severidade $^{1}$ & Índice de Doença \\
\hline Blocos & 4 & $0,4483^{\star \star}$ & $2240,37^{\star \star}$ \\
\hline Vasos & 69 & $0,0279^{\star *}$ & $199,43^{\star *}$ \\
\hline Genótipos & 14 & $0,0468^{* *}$ & $314,45^{\star *}$ \\
\hline Genitores (G) & 4 & $0,0608^{\star *}$ & $395,69^{*}$ \\
\hline Cruzamentos $\mathrm{F}_{2}(\mathrm{C})$ & 9 & $0,0456^{* *}$ & $307,60^{*}$ \\
\hline Genitores vs. Cruzamentos $F_{2}$ & 1 & 0,0014 & 51,11 \\
\hline Vasos/Genótipos & 55 & $0,0231^{*}$ & 170,16 \\
\hline Vasos/Genitores & 5 & 0,0132 & 87,71 \\
\hline Vasos/Cruzamentos $F_{2}$ & 50 & $0,0240^{*}$ & $178,70^{*}$ \\
\hline Resíduo (Blocos x Vasos) & 276 & 0,0166 & 127,27 \\
\hline Blocos x Vasos de Genitores & 36 & 0,0130 & 92,30 \\
\hline Blocos $x$ Vasos de Cruzamentos $F_{2}$ & 236 & 0,0172 & 133,62 \\
\hline Blocos x (Vasos de G vs. Vasos de C) & 4 & 0,0111 & 67,27 \\
\hline Total & 349 & --- & --- \\
\hline Qui-quadrado (teste de Bartlett) & --- & 2,03 & 2,30 \\
\hline C.V. (\%) & --- & 7,3 & 25,6 \\
\hline
\end{tabular}

${ }^{1}$ Dados transformados para $\sqrt{x+0,5}$.

${ }^{*},{ }^{* \star}$ Significativo pelo teste $\mathrm{F}$ (ou qui-quadrado), a $5 \%$ e $1 \%$ de probabilidade, respectivamente. 
Tabela 10. Resumo da análise de variância (média de cinco plantas/vaso) de contrastes para os sintomas foliares da PVR (severidade= escala de 1 a 5 , e índice de doença), na geração $F_{2}$ do dialelo $5 \times 5$ conduzido em casa de vegetação (CV-SET01). Soja, Piracicaba-SP.

\begin{tabular}{|c|c|c|c|}
\hline \multirow[b]{2}{*}{ Contrastes Ortogonais } & \multirow[b]{2}{*}{$\mathrm{GL}$} & \multicolumn{2}{|c|}{ Quadrados Médios } \\
\hline & & Severidade $^{1}$ & Índice de Doença \\
\hline Genitores vs. Cruzamentos $F_{2}$ & 1 & 0,0014 & 51,11 \\
\hline 'Forrest' vs. 'Conquista' & 1 & 0,0170 & 223,78 \\
\hline ('Forrest' + 'Conquista') vs. demais Genitores & 1 & 0,0568 & $628,72^{*}$ \\
\hline ('Cristalina' + 'Estrela') vs. 'IAC-4' & 1 & $0,1613^{\star *}$ & $690,20^{*}$ \\
\hline 'Cristalina' vs. 'Estrela' & 1 & 0,0081 & 40,04 \\
\hline ('Conquista'x'Forrest') vs. demais Cruzamentos & 1 & 0,0465 & 268,10 \\
\hline Cruzamentos "Suscetíveis" vs. Cruzamentos "Resistentes" & 1 & $0,0961^{*}$ & $632,45^{\star}$ \\
\hline ('Cristalina'X'IAC-4' + 'Cristalina'x’Estrela') vs. ('IAC-4’X’Estrela') & 1 & 0,0005 & 26,60 \\
\hline ('Cristalina'x'IAC-4’) vs. ('Cristalina’X’Estrela') & 1 & 0,0438 & 416,07 \\
\hline $\begin{array}{l}\text { ('Conquista'x'Cristalina' + 'Conquista'x'IAC-4' + 'Conquista'x'Estrela } \\
\text { 'Cristalina' + 'Forrest'x'IAC-4' + 'Forrest'x'Estrela') }\end{array}$ & 1 & 0,0367 & 112,02 \\
\hline ('Conquista'x'Cristalina' + 'Conquista'x’Estrela') vs. ('Conquista'x'IAC-4’) & 1 & 0,0053 & 135,20 \\
\hline ('Conquista’x'Cristalina') vs. ('Conquista’x’Estrela') & 1 & $0,1795^{\star *}$ & $909,48^{* *}$ \\
\hline ('Forrest'x'Cristalina' + 'Forrest'x'Estrela') vs. ('Forrest'x'IAC-4') & 1 & 0,0007 & 17,17 \\
\hline ('Forrest'x'Cristalina') vs. ('Forrest'x'Estrela') & 1 & 0,0019 & 251,33 \\
\hline
\end{tabular}

${ }^{1}$ Dados transformados para $\sqrt{\mathrm{x}+0,5}$.

*, ${ }^{* *}$ Significativo pelo teste $\mathrm{F}$, a $5 \%$ e $1 \%$ de probabilidade, respectivamente. 
Tabela 11. Análise de variância (média de cinco plantas/vaso) para severidade (notas 1 a 5) e índice de doença dos sintomas foliares da PVR, considerando a nota do folíolo com sintomas mais intensos (SF e IDF) ou o aspecto geral da planta (SP e IDP), e severidade desconsiderando plantas com nota de aspecto geral igual a 1 (SP1), na geração $F_{2}$ do dialelo $5 \times 5$ conduzido em casa de vegetação (CV-JUL02). Soja, Piracicaba-SP.

\begin{tabular}{|c|c|c|c|c|c|c|}
\hline \multirow[b]{2}{*}{ Fontes de Variação } & \multirow[b]{2}{*}{$\mathrm{GL}^{1}$} & \multicolumn{5}{|c|}{ Quadrados Médios } \\
\hline & & SF & IDF & SP & IDP & SP1 \\
\hline Genótipos & 14 & $4,3377^{\star \star}$ & $3624,3^{\star *}$ & $4,0193^{\star *}$ & $3190,7^{* *}$ & $2,5538^{* *}$ \\
\hline Genitores (G) & 4 & $2,1714^{*}$ & 745,5 & $2,1995^{\star *}$ & 740,5 & $3,5117^{\star *}$ \\
\hline Cruzamentos $\mathrm{F}_{2}(\mathrm{C})$ & 9 & $5,4492^{\star *}$ & $4759,5^{\star *}$ & $4,9087^{\star *}$ & $4112,3^{* *}$ & $2,4094^{\star *}$ \\
\hline G vs. C & 1 & $2,9995^{\star}$ & $4922,8^{* *}$ & $3,2939^{*}$ & $4696,8^{* *}$ & 0,0553 \\
\hline Resíduo & 335 & 0,7411 & 542,2 & 0,6106 & 447,0 & 0,5492 \\
\hline Resíduo de Genitores & 45 & 0,7910 & 515,8 & 0,7250 & 463,0 & 0,6122 \\
\hline Resíduo de Cruzamentos $F_{2}$ & 290 & 0,7334 & 546,3 & 0,5928 & 444,5 & 0,5395 \\
\hline Total & 349 & --- & --- & --- & --- & --- \\
\hline Qui-quadrado (teste de Bartlett) & --- & 0,10 & 0,06 & 0,85 & 0,03 & 0,28 \\
\hline C.V. (\%) & --- & 27,4 & 38,3 & 28,8 & 39,9 & 24,1 \\
\hline
\end{tabular}


Tabela 12. Resumo da análise de variância (média de anco plantas/vaso) de contrastes para severidade (notas 1 a 5 ) e índice de doença dos sintomas foliares da PVR, considerando a nota do folíolo com sintomas mais intensos (SF e IDF) ou o aspecto geral da planta (SP e IDP), e severidade desconsiderando plantas com nota de aspecto geral igual a 1 (SP1), na geração $F_{2}$ do dialelo $5 \times 5$ conduzido em casa de vegetação (CV-JUL02). Soja, Piracicaba-SP.

\begin{tabular}{|c|c|c|c|c|c|c|}
\hline \multirow[b]{2}{*}{ Contrastes Ortogonais } & \multirow[b]{2}{*}{$\mathrm{GL}$} & \multicolumn{5}{|c|}{ Quadrados Médios } \\
\hline & & SF & IDF & SP & IDP & SP1 \\
\hline Genitores vs. Cruzamentos $F_{2}$ & 1 & $2,9995^{\star}$ & $4922,8^{\star \star}$ & $3,2918^{*}$ & $4696,8^{* *}$ & 0,0552 \\
\hline 'Forrest' vs. 'Conquista' & 1 & 0,0690 & 161,0 & 0,0061 & 206,1 & 0,6501 \\
\hline ('Forrest' + 'Conquista') vs. demais Genitores & 1 & $7,7040^{\star *}$ & $2081,7^{\star}$ & $8,4336^{\star *}$ & $2354,2^{*}$ & $13,1879^{* *}$ \\
\hline ('Cristalina' + 'Estrela') vs. 'IAC-4' & 1 & 0,0094 & 2,5 & 0,0001 & 0,1 & 0,1830 \\
\hline 'Cristalina' vs. 'Estrela' & 1 & 0,9031 & 736,9 & 0,3645 & 401,4 & 0,1441 \\
\hline ('Conquista'x'Forrest') vs. demais Cruzamentos & 1 & $6,3864^{\star \star}$ & $4045,9^{\star \star}$ & $6,2763^{* *}$ & $3718,5^{\star \star}$ & $2,8070^{*}$ \\
\hline Cruzamentos "Suscetíveis" vs. Cruzamentos "Resistentes" & 1 & $23,3372^{\star *}$ & $16028,3^{* *}$ & $22,1843^{* *}$ & $14692,2^{\star *}$ & $10,5896^{* *}$ \\
\hline ('Cristalina'X'IAC-4' + 'Cristalina'x'Estrela') vs. ('IAC-4'x'Estrela') & 1 & 0,0028 & 257,3 & 0,0710 & 127,2 & 1,6675 \\
\hline ('Cristalina'x'IAC-4') vs. ('Cristalina'x’Estrela') & 1 & 0,6988 & 198,0 & 1,2398 & 378,5 & $2,1945^{\star}$ \\
\hline $\begin{array}{l}\text { ('Conquista'x'Cristalina' + 'Conquista'x'IAC-4' + 'Conquista'x'Estrela') vs } \\
\text { ('Forrest'x'Cristalina' + 'Forrest'x'IAC-4' + 'Forrest'x'Estrela') }\end{array}$ & 1 & 1,4625 & $4091,2^{\star *}$ & 1,3377 & $3572,5^{\star *}$ & $2,5782^{*}$ \\
\hline ('Conquista'x'Cristalina' + 'Conquista'x’Estrela') vs. ('Conquista'x'IAC-4') & 1 & $3,5001^{*}$ & $3612,4^{*}$ & $3,0853^{*}$ & $3196,2^{* *}$ & 0,0017 \\
\hline ('Conquista'x'Cristalina') vs. ('Conquista'x’Estrela') & 1 & 0,6477 & 557,6 & 0,2734 & 317,9 & 0,1653 \\
\hline ('Forrest'x'Cristalina' + 'Forrest'x'Estrela') vs. ('Forrest'x'IAC-4') & 1 & $12,7201^{* *}$ & $13224,2^{* *}$ & $9,5602^{* *}$ & $10444,0^{\star *}$ & 1,3898 \\
\hline ('Forrest'x'Cristalina') vs. ('Forrest'x'Estrela') & 1 & 0,2870 & 820,2 & 0,1568 & 563,7 & 0,1434 \\
\hline
\end{tabular}

${ }^{*, \star \star}$ Significativo pelo teste $\mathrm{F}$, a $5 \%$ e $1 \%$ de probabilidade, respectivamente. 
Tabela 13. Análise de variância de $\hat{W}_{i}-\hat{V}_{i}$ e $\hat{W}_{i}+\hat{V}_{i}$ para severidade (SF) e índice de doença (IDF) dos sintomas foliares da PVR, em dois experimentos conduzidos com a geração $F_{2}$ do dialelo 5x5, durante 2001 (TE-JUL01 e CV-SET01). Soja, PiracicabaSP.

\begin{tabular}{|c|c|c|c|c|c|c|}
\hline \multirow[b]{3}{*}{ Variáveis } & \multirow{3}{*}{$\begin{array}{l}\text { Fontes de } \\
\text { Variação }\end{array}$} & \multirow[b]{3}{*}{$\mathrm{GL}$} & \multicolumn{4}{|c|}{ Quadrados Médios } \\
\hline & & & \multicolumn{2}{|c|}{ Telado } & \multicolumn{2}{|c|}{ Casa de Vegetação } \\
\hline & & & Severidade $^{1}$ & Índice Doença & Severidade $^{1}$ & Índice Doença \\
\hline \multirow{3}{*}{$\hat{W}_{i}-\hat{V}_{i}$} & Blocos & 4 & $0,059382^{\star \star}$ & $125668,2^{* *}$ & $0,218054^{\star \star}$ & $792221,1^{* *}$ \\
\hline & Linhas & 4 & 0,000019 & 591,7 & 0,000080 & 2689,8 \\
\hline & Resíduo & 16 & 0,000011 & 634,6 & 0,000033 & 1105,2 \\
\hline \multirow{3}{*}{$\hat{W}_{i}+\hat{V}_{i}$} & Blocos & 4 & $0,061896^{\star *}$ & $119661,0^{\star *}$ & $0,222910^{\star \star}$ & $843396,5^{\star *}$ \\
\hline & Linhas & 4 & 0,000061 & 4271,3 & 0,000070 & 2864,5 \\
\hline & Resíduo & 16 & 0,000082 & 4788,4 & 0,000075 & 3766,7 \\
\hline
\end{tabular}

${ }^{1}$ Dados transformados para $\sqrt{\mathrm{x}+0,5}$.

** Significativo pelo teste $\mathrm{F}$, a $1 \%$ de probabilidade. 
Tabela 14. Testes de suficiência do modelo genético aditivo-dominante de Jinks-Hayman, com base na análise de regressão linear de $\hat{W}_{i}$ em função de $\hat{V}_{i}$, para severidade (notas 1 a 5) e índice de doença dos sintomas foliares da PVR, considerando a nota do folíolo com sintomas mais intensos (SF e IDF) ou o aspecto geral da planta (SP e IDP), e severidade desconsiderando plantas com nota de aspecto geral igual a 1 (SP1), em três experimentos com a geração $F_{2}$ do dialelo $5 \times 5$. Soja, Piracicaba-SP.

\begin{tabular}{|c|c|c|c|c|c|}
\hline Experimentos & Caracteres & $\hat{b} \pm s_{b}$ & $r^{2}(\%)$ & $\begin{array}{l}\text { valor de } t \\
\left(H_{0}: b=1\right)\end{array}$ & $\begin{array}{c}\text { valor de } F=" t^{2,} \\
\left(H_{0}: b^{\prime}=0\right)\end{array}$ \\
\hline \multirow[t]{2}{*}{ TE-JUL01 } & $\mathrm{SF}^{1}$ & $1,04 \pm 0,08$ & $98,2^{\star \star 4}$ & 0,50 & 0,40 \\
\hline & IDF & $0,96 \pm 0,11$ & $96,0^{\star \star}$ & $-0,36$ & 0,03 \\
\hline \multirow[t]{5}{*}{ CV-SET01 } & $\mathrm{SF}^{1}$ & $0,94 \pm 0,29$ & $78,4^{*}$ & $-0,21$ & 0,05 \\
\hline & IDF & $0,97 \pm 0,29$ & $78,8^{*}$ & $-0,10$ & 0,12 \\
\hline & SF & $0,74 \pm 0,20$ & $82,0^{*}$ & $-1,30$ & 0,69 \\
\hline & IDF & $0,43 \pm 0,23$ & 52,0 & $-2,45$ & 1,94 \\
\hline & IDF $^{2}$ & $0,72 \pm 0,20$ & 80,9 & $-1,16$ & 0,56 \\
\hline \multirow[t]{4}{*}{ CV-JUL02 } & $\mathrm{SP}$ & $0,80 \pm 0,18$ & $86,7^{*}$ & $-1,08$ & 0,49 \\
\hline & IDP & $0,50 \pm 0,24$ & 59,8 & $-2,07$ & 1,45 \\
\hline & $\mathrm{IDP}^{2}$ & $0,72 \pm 0,20$ & 81,0 & $-1,11$ & 0,50 \\
\hline & $\mathrm{SP} 1^{3}$ & $0,74 \pm 0,30$ & 66,9 & $-0,88$ & 0,10 \\
\hline
\end{tabular}

${ }^{1}$ Dados transformados para $\sqrt{\mathrm{x}+0,5}$.

${ }^{2}$ Análise realizada sem o genitor 'Cristalina'.

${ }^{3}$ Plantas com nota de aspecto geral igual a 1 foram consideradas escapes e não participaram das análises.

${ }^{4}$ Resultado da análise de variância do modelo de regressão linear.

*,** Significativo pelo teste $\mathrm{F}$, a $5 \%$ e $1 \%$ de probabilidade, respectivamente. 
Tabela 15. Resumo da análise de variância para severidade (SF) e índice de doença (IDF) dos sintomas foliares da PVR, considerando a nota do folíolo com sintomas mais intensos, com as respectivas decomposições de genótipos nos componentes aditivo e de dominância, em dois experimentos (TE-JUL01 e CV-SET01) conduzidos com a geração $F_{2}$ do dialelo $5 \times 5$. Soja, Piracicaba-SP.

\begin{tabular}{|c|c|c|c|c|c|}
\hline \multirow{3}{*}{$\begin{array}{l}\text { Fontes de } \\
\text { Variação }\end{array}$} & \multirow[b]{3}{*}{ GL } & \multicolumn{4}{|c|}{ Quadrados Médios } \\
\hline & & \multicolumn{2}{|c|}{ Telado } & \multicolumn{2}{|c|}{ Casa de Vegetação } \\
\hline & & Severidade $^{1}$ & Índice Doença & Severidade $^{1}$ & Índice Doença \\
\hline Genótipos & 14 & $0,003528^{\star \star}$ & $24,7503^{*}$ & $0,002724^{\star \star}$ & $19,4881^{\star \star}$ \\
\hline a & 4 & $0,010899^{\star *}$ & $73,9264^{* *}$ & $0,007412^{\star \star}$ & $54,7260^{* *}$ \\
\hline$b$ & 10 & 0,000579 & 5,0798 & 0,000848 & 5,3929 \\
\hline$b_{1}$ & 1 & 0,000827 & 3,0083 & 0,000109 & 5,5642 \\
\hline$b_{2}$ & 4 & 0,000620 & 9,0473 & 0,000987 & 1,3661 \\
\hline$b_{3}$ & 5 & 0,000497 & 2,3201 & 0,000885 & 8,5801 \\
\hline Resíduo & 276 & 0,001533 & 12,8484 & 0,000921 & 7,0706 \\
\hline
\end{tabular}

${ }^{1}$ Dados transformados para $\sqrt{\mathrm{x}+0,5}$.

*,** Significativo pelo teste $\mathrm{F}$, a 5 e $1 \%$ de probabilidade, respectivamente. 
Tabela 16. Resumo da análise de variância para severidade (notas 1 a 5) e índice de doença dos sintomas foliares da PVR, considerando a nota do folíolo com sintomas mais intensos (SF e IDF) ou o aspecto geral da planta (SP e IDP), e severidade desconsiderando plantas com nota de aspecto geral igual a 1 (SP1), com as respectivas decomposições de genótipos nos componentes aditivo e de dominância, na geração $F_{2}$ do dialelo $5 \times 5$ conduzido em casa de vegetação (CV-JUL02). Soja, Piracicaba-SP.

\begin{tabular}{|c|c|c|c|c|c|c|}
\hline \multirow{2}{*}{$\begin{array}{l}\text { Fontes de } \\
\text { Variação }\end{array}$} & \multirow[b]{2}{*}{$\mathrm{GL}^{1}$} & \multicolumn{5}{|c|}{ Quadrados Médios } \\
\hline & & SF & IDF & SP & IDP & SP1 \\
\hline Genótipos & 14 & $0,195463^{* *}$ & $150,63^{\star *}$ & $0,186379^{* *}$ & $135,38^{* *}$ & $0,155052^{* *}$ \\
\hline a & 4 & $0,475577^{\star \star}$ & $267,27^{\star *}$ & $0,481969^{\star *}$ & $259,11^{\star *}$ & $0,474957^{\star \star}$ \\
\hline$b$ & 10 & $0,083417^{*}$ & $103,97^{\star *}$ & $0,068143^{*}$ & $85,89^{* *}$ & 0,027089 \\
\hline$b_{1}$ & 1 & $0,233307^{\star}$ & $382,78^{\star *}$ & $0,256040^{\star \star}$ & $365,40^{\star \star}$ & 0,004392 \\
\hline$b_{2}$ & 4 & 0,091180 & $103,21^{\star *}$ & 0,063778 & $79,04^{\star}$ & 0,025541 \\
\hline$b_{3}$ & 5 & 0,047229 & 48,82 & 0,034055 & 35,47 & 0,032867 \\
\hline Resíduo & 335 & 0,041172 & 30,12 & 0,033916 & 24,83 & 0,030513 \\
\hline
\end{tabular}

${ }^{*},{ }^{* *}$ Significativo pelo teste $\mathrm{F}$, a $5 \%$ e $1 \%$ de probabilidade, respectivamente.

${ }^{1}$ Para o caráter SP1 o número de graus de liberdade para a fonte de variação Resíduo foi 328. 
Tabela 17. Resumo da análise de variância (sem o genitor 'Cristalina') para o índice de doença dos sintomas foliares da PVR, considerando a nota do folíolo com sintomas mais intensos (IDF) e o aspecto geral da planta (IDP), com as respectivas decomposições de genótipos nos componentes aditivo e de dominância, na geração $F_{2}$ do dialelo $5 \times 5$ conduzido em casa de vegetação (CV-JUL02). Soja, Piracicaba-SP.

\begin{tabular}{|c|c|c|c|}
\hline \multirow{2}{*}{$\begin{array}{l}\text { Fontes de } \\
\text { Variação }\end{array}$} & \multirow[b]{2}{*}{$\mathrm{GL}$} & \multicolumn{2}{|c|}{ Quadrados Médios } \\
\hline & & IDF & IDP \\
\hline Genótipos & 9 & $199,50^{* *}$ & $175,20^{\star *}$ \\
\hline a & 3 & $260,10^{\star *}$ & $241,98^{\star *}$ \\
\hline$b$ & 6 & $169,20^{* *}$ & $141,81^{* *}$ \\
\hline$b_{1}$ & 1 & $619,27^{\star *}$ & $528,84^{\star *}$ \\
\hline$b_{2}$ & 3 & $82,00^{\star}$ & $68,40^{*}$ \\
\hline$b_{3}$ & 2 & 74,97 & 58,42 \\
\hline Resíduo & 210 & 29,40 & 23,38 \\
\hline
\end{tabular}

*,** Significativo pelo teste $\mathrm{F}$, a 5 e $1 \%$ de probabilidade, respectivamente. 
Tabela 18. Estimativas dos componentes genéticos, com seus respectivos desvios padrões, do modelo genético aditivo-dominante de Jinks-Hayman, para severidade (notas 1 a 5) e índice de doença dos sintomas foliares da PVR, considerando a nota do folíolo com sintomas mais intensos (SF e IDF) ou o aspecto geral da planta (SP e IDP), e severidade desconsiderando plantas com nota de aspecto geral igual a 1 (SP1), em três experimentos conduzidos com a geração $F_{2}$ do dialelo $5 \times 5$. Soja, Piracicaba-SP.

\begin{tabular}{|c|c|c|c|c|c|}
\hline \multirow[b]{2}{*}{ Experimentos } & \multirow[b]{2}{*}{ Caracteres } & \multicolumn{4}{|c|}{ Componentes Genéticos $^{1}$} \\
\hline & & $\hat{\mathrm{D}}$ & $\hat{\mathrm{H}}_{1}$ & $\hat{\mathrm{H}}_{2}$ & $\hat{\mathrm{F}}$ \\
\hline \multirow[t]{2}{*}{ TE-JUL01 } & $\mathrm{SF}^{2}$ & $0,0042^{* *} \pm 0,0003$ & $-0,0159^{* *} \pm 0,0005$ & $-0,0106^{* *} \pm 0,0003$ & $-0,0035^{\star} \pm 0,0006$ \\
\hline & IDF & $26,32^{\star \star} \pm 3,75$ & $-129,86^{\star \star} \pm 7,94$ & $-96,10^{* *} \pm 4,60$ & $-22,74 \pm 9,32$ \\
\hline \multirow[t]{5}{*}{ CV-SET01 } & $\mathrm{SF}^{2}$ & $0,0032^{* *} \pm 0,0006$ & $0,0024 \pm 0,0013$ & $0,0024 \pm 0,0008$ & $0,0032 \pm 0,0016$ \\
\hline & IDF & $30,34^{\star *} \pm 4,69$ & $-4,82 \pm 9,94$ & $10,98 \pm 5,77$ & $11,98 \pm 11,68$ \\
\hline & SF & $0,1380 \pm 0,0705$ & $0,6874^{*} \pm 0,1494$ & $0,5575^{\star \star} \pm 0,0867$ & $-0,2334 \pm 0,1755$ \\
\hline & IDF & $23,00 \pm 91,03$ & $1127,81^{\star} \pm 192,85$ & $901,90^{\star *} \pm 111,84$ & $-218,75 \pm 226,49$ \\
\hline & $\mathrm{IDF}^{3}$ & $64,32 \pm 74,43$ & $1818,55^{\star \star} \pm 155,07$ & $1660,40^{\star \star} \pm 90,00$ & $-210,54 \pm 185,11$ \\
\hline \multirow[t]{4}{*}{ CV-JUL02 } & SP & $0,1476 \pm 0,0533$ & $0,4753^{\star} \pm 0,1130$ & $0,4160^{* *} \pm 0,0655$ & $-0,2523 \pm 0,1327$ \\
\hline & IDP & $27,74 \pm 72,35$ & $879,35^{\star} \pm 153,28$ & $718,39^{\star \star} \pm 88,90$ & $-223,53 \pm 180,02$ \\
\hline & $\mathrm{IDP}^{3}$ & $69,21 \pm 69,15$ & $1524,64^{\star \star} \pm 144,07$ & $1390,43^{\star *} \pm 83,61$ & $-178,90 \pm 171,98$ \\
\hline & $\mathrm{SP} 1^{4}$ & $0,2981^{* *} \pm 0,0238$ & $-0,0077 \pm 0,0505$ & $0,0407 \pm 0,0293$ & $0,1299 \pm 0,0593$ \\
\hline
\end{tabular}

${ }^{1}$ Os desvios padrões de cada estimativa foram calculados segundo Hayman (1958) e corrigidos com base em Ferreira (1985).

${ }^{2}$ Dados transformados para $\sqrt{\mathrm{x}+0,5}$.

${ }^{3}$ Análise realizada sem o genitor 'Cristalina'.

${ }^{4}$ Plantas com nota de aspecto geral igual a 1 foram consideradas escapes e não participaram das análises.

*, ${ }^{* *}$ Significativo pelo teste $\mathrm{t}$, a $5 \%$ e $1 \%$ de probabilidade, respectivamente. 
Tabela 19. Estimativas dos parâmetros genéticos do modelo genético aditivo-dominante de Jinks-Hayman, ordem decrescente de dominância e relação entre alelos favoráveis e dominância (r), para severidade (notas 1 a 5 ) e índice de doença dos sintomas foliares da PVR, considerando a nota do folíolo com sintomas mais intensos (SF e IDF) ou o aspecto geral da planta (SP e IDP), e severidade desconsiderando plantas com nota de aspecto geral igual a 1 (SP1), em três experimentos conduzidos com a geração $F_{2}$ do dialelo $5 \times 5$. Soja, Piracicaba-SP.

\begin{tabular}{|c|c|c|c|c|c|c|c|c|c|c|}
\hline \multirow[b]{2}{*}{ Experimentos } & \multirow[b]{2}{*}{ Caracteres } & \multicolumn{7}{|c|}{ Parâmetros Genéticos } & \multirow{2}{*}{$\begin{array}{c}\text { Ordem } \\
\text { Decrescente de } \\
\text { Dominância }^{4}\end{array}$} & \multirow[b]{2}{*}{$r$} \\
\hline & & gînd & $\frac{\hat{\mathrm{K}}_{\mathrm{D}}}{\hat{\mathrm{K}}_{\mathrm{R}}}$ & $\overline{i v}$ & $(\grave{i}-v) \frac{h}{d}$ & $\hat{\mathrm{N}}$ & $h_{r}^{2}$ & $\mathrm{~h}_{\mathrm{a}}^{2}$ & & \\
\hline \multirow[t]{2}{*}{ TE-JUL01 } & $\mathrm{SF}^{1}$ & - & - & 0,17 & 0,41 & -5 & 0,30 & -5 & ES,CR,I-4,CO,FO & $-0,7 C$ \\
\hline & IDF & - & - & 0,18 & 0,41 & -5 & 0,26 & -5 & $\mathrm{CR}, \mathrm{ES}, \mathrm{I}-4, \mathrm{CO}, \mathrm{FO}$ & $-0,9$ \\
\hline \multirow[t]{2}{*}{ CV-SET01 } & $\mathrm{SF}^{1}$ & 0,71 & 2,84 & 0,25 & - & 0,22 & 0,16 & 0,29 & $\mathrm{FO}, \mathrm{ES}, \mathrm{CO}, \mathrm{l}-4, \mathrm{CR}$ & 0,05 \\
\hline & IDF & - & - & -5 & - & 1,74 & 0,04 & 0,14 & $\mathrm{FO}, \mathrm{I}-4, \mathrm{CO}, \mathrm{ES}, \mathrm{CR}$ & 0,44 \\
\hline \multirow{7}{*}{ CV-JUL02 } & SF & 2,23 & 0,45 & 0,20 & 0,87 & 2,01 & 0,58 & 0,90 & $\mathrm{CO}, \mathrm{CR}, \mathrm{FO}, \mathrm{ES}, \mathrm{I}-4$ & 0,61 \\
\hline & IDF & 7,00 & 0,19 & 0,20 & 1,52 & 2,04 & 0,48 & 0,95 & $\mathrm{CO}, \mathrm{CR}, \mathrm{FO}, \mathrm{ES}, \mathrm{I}-4$ & 0,65 \\
\hline & $\mathrm{IDF}^{2}$ & 5,32 & 0,53 & 0,23 & 1,04 & 2,49 & 0,33 & 0,96 & $\mathrm{CO}, \mathrm{FO}, \mathrm{ES}, \mathrm{l}-4$ & 0,71 \\
\hline & SP & 1,80 & 0,35 & 0,22 & 1,35 & 2,95 & 0,62 & 0,91 & $\mathrm{CO}, \mathrm{CR}, \mathrm{FO}, \mathrm{ES}, \mathrm{I}-4$ & 0,66 \\
\hline & IDP & 5,63 & 0,17 & 0,20 & 1,67 & 2,44 & 0,51 & 0,95 & $\mathrm{CO}, \mathrm{CR}, \mathrm{FO}, \mathrm{ES}, \mathrm{I}-4$ & 0,66 \\
\hline & $\mathrm{IDP}^{2}$ & 4,69 & 0,57 & 0,23 & 0,93 & 2,54 & 0,34 & 0,96 & $\mathrm{CO}, \mathrm{FO}, \mathrm{ES}, \mathrm{I}-4$ & 0,71 \\
\hline & $\mathrm{SP} 1^{3}$ & - & - & -5 & -5 & 0,52 & 0,60 & 0,70 & $\mathrm{CO}, \mathrm{FO}, \mathrm{CR}, \mathrm{ES}, \mathrm{I}-4$ & 0,70 \\
\hline
\end{tabular}

${ }^{1}$ Dados transformados para $\sqrt{\mathrm{x}+0,5}$.

${ }^{2}$ Análise realizada sem o genitor 'Cristalina'.

${ }^{3}$ Plantas com nota de aspecto geral igual a 1 foram consideradas escapes e não participaram das análises.

${ }^{4}$ Ordem crescente de $\hat{W}_{i}+\hat{V}_{i}$. CO: 'Conquista', CR: 'Cristalina', ES: 'Estrela', FO: 'Forrest' e I-4: 'IAC-4'.

${ }^{5}$ Valores negativos. 
Tabela 20. Média e variância para os caracteres número de dias para a maturidade, altura da planta na maturidade, produtividade de grãos por planta e valor agronômico de plantas $\mathrm{F}_{3: 2}$ do dialelo $5 \times 5$ conduzidas pelo método SHDT. Soja, Piracicaba-SP, semeadura em 05/12/2001.

\begin{tabular}{|c|c|c|c|c|c|c|c|c|c|}
\hline \multirow[b]{2}{*}{ Genótipos } & \multirow{2}{*}{$\begin{array}{c}\text { Número de } \\
\text { Plantas }\end{array}$} & \multicolumn{2}{|c|}{ Maturidade (dias) } & \multicolumn{2}{|c|}{ Altura da Planta $(\mathrm{cm})$} & \multicolumn{2}{|c|}{ Produtividade (g/planta) } & \multicolumn{2}{|c|}{ Valor Agronômico (1 a 5) } \\
\hline & & Média & Variância & Média & Variância & Média & Variância & Média & Variância \\
\hline Conquista & 15 & $131,6(4)^{a}$ & $2,5(5)$ & $53,7(2)$ & $62,4(1)$ & $57,0(2)$ & $352,4(3)$ & $3,13(1)$ & $0,27(2)$ \\
\hline Cristalina & 13 & $141,5(5)$ & $15,8(2)$ & $54,2(1)$ & $41,0(3)$ & $90,9(1)$ & $1813,0(1)$ & $3,12(2)$ & $0,21(3)$ \\
\hline Estrela & 13 & $118,4(2)$ & $11,8(4)$ & $41,5(3)$ & $47,4(2)$ & $51,8(3)$ & 450,8 (2) & 2,27 (4) & $0,40(1)$ \\
\hline Forrest & 15 & $108,3(1)$ & $114,4(1)$ & $35,0(5)$ & $17,9(5)$ & $25,0(5)$ & $23,7(5)$ & $1,43(5)$ & $0,07(4)$ \\
\hline IAC-4 & 12 & $129,9(3)$ & $13,0(3)$ & $41,2(4)$ & $23,3(4)$ & $49,6(4)$ & $150,5(4)$ & $2,42(3)$ & $0,27(2)$ \\
\hline Conquista $\times$ Cristalina & 74 & $137,7(10)$ & $16,7(9)$ & $53,6(1)$ & $115,3(1)$ & $70,7(1)$ & $730,0(2)$ & $3,01(1)$ & $0,45(8)$ \\
\hline Conquista $\times$ Estrela & 68 & $124,5(5)$ & $52,9(7)$ & $47,8(2)$ & $87,6(3)$ & $61,7(4)$ & $722,9(3)$ & $2,76(2)$ & $0,65(1)$ \\
\hline Conquista $\times$ Forrest & 99 & $117,6(3)$ & $110,8(2)$ & $40,1(8)$ & $53,3(8)$ & $36,8(9)$ & $422,0(8)$ & $1,91(8)$ & $0,51(5)$ \\
\hline Conquista $\times$ IAC-4 & 90 & $127,4(6)$ & $56,1(5)$ & $45,9(5)$ & $73,5(5)$ & $54,0(5)$ & $449,5(7)$ & $2,66(4)$ & $0,64(2)$ \\
\hline Cristalina $x$ Estrela & 37 & $134,3(9)$ & $39,8(8)$ & $46,9(3)$ & $111,6(2)$ & $66,0(2)$ & $892,5(1)$ & $2,65(5)$ & $0,48(7)$ \\
\hline Cristalina $x$ Forrest & 28 & $121,9(4)$ & $123,7(1)$ & $40,9(7)$ & $87,1(4)$ & $43,8(7)$ & $498,9(4)$ & $2,14(7)$ & $0,52(4)$ \\
\hline Cristalina x IAC-4 & 28 & $133,1(8)$ & $63,3(4)$ & $46,8(4)$ & $54,1(7)$ & $61,8(3)$ & $498,2(5)$ & $2,68(3)$ & $0,50(6)$ \\
\hline Estrela $x$ Forrest & 89 & $113,8(1)$ & $54,5(6)$ & $36,5(10)$ & $30,8(10)$ & $37,4(8)$ & $202,5(10)$ & $1,83(9)$ & $0,25(10)$ \\
\hline Estrela x IAC-4 & 32 & $130,1(7)$ & $63,3(4)$ & $42,5(6)$ & $56,5(6)$ & $51,6(6)$ & $493,0(6)$ & $2,32(6)$ & $0,61(3)$ \\
\hline Forrest $x$ IAC-4 & 33 & $116,3(2)$ & $67,8(3)$ & $37,6(9)$ & $40,8(9)$ & $33,8(10)$ & $242,0(9)$ & $1,82(10)$ & $0,31(9)$ \\
\hline Média genitores & $\begin{array}{c}-- \\
\end{array}$ & 125,9 & 31,5 & 45,1 & 38,4 & 54,9 & 558,1 & 2,47 & 0,24 \\
\hline Média $F_{3: 2}$ & --- & 125,7 & 64,9 & 43,9 & 71,1 & 51,8 & 515,1 & 2,38 & 0,49 \\
\hline Média geral & --- & 125,8 & 53,8 & 44,3 & 60,2 & 52,8 & 529,5 & 2,41 & 0,41 \\
\hline
\end{tabular}

\footnotetext{
${ }^{\mathrm{a}}$ Entre parênteses está a ordem de classificação entre genitores e entre cruzamentos $\mathrm{F}_{2}$.
} 
Tabela 21. Média e variância para os caracteres número de dias para a maturidade, altura da planta na maturidade, produtividade de grãos por planta e valor agronômico de plantas $\mathrm{F}_{3: 2}$ do dialelo $5 \times 5$ conduzidas pelo método SHDT (com mesmo número de parcelas entre os cruzamentos e entre os genitores). Soja, Piracicaba-SP, semeadura em 05/12/2001.

\begin{tabular}{|c|c|c|c|c|c|c|c|c|c|}
\hline \multirow[b]{2}{*}{ Genótipos } & \multirow{2}{*}{$\begin{array}{c}\text { Número de } \\
\text { Plantas }\end{array}$} & \multicolumn{2}{|c|}{ Maturidade (dias) } & \multicolumn{2}{|c|}{ Altura da Planta $(\mathrm{cm})$} & \multicolumn{2}{|c|}{ Produtividade (g/planta) } & \multicolumn{2}{|c|}{ Valor Agronômico (1 a 5) } \\
\hline & & Média & Variância & Média & Variância & Média & Variância & Média & Variância \\
\hline Conquista & 12 & $131,4(4)^{\mathrm{a}}$ & $2,1(5)$ & $55,4(1)$ & $52,1(1)$ & $59,3(2)$ & $399,4(3)$ & $3,25(1)$ & $0,20(4)$ \\
\hline Cristalina & 12 & $141,1(5)$ & $15,2(2)$ & $54,2(2)$ & $44,7(3)$ & $94,0(1)$ & $1839,3(1)$ & $3,12(2)$ & $0,23(3)$ \\
\hline Estrela & 12 & $118,5(2)$ & $12,6(4)$ & $41,7(3)$ & $51,5(2)$ & $52,8(3)$ & $475,7(2)$ & $2,25(4)$ & $0,43(1)$ \\
\hline Forrest & 12 & $109,1(1)$ & $139,5(1)$ & $35,4(5)$ & $20,3(5)$ & $26,3(5)$ & $20,6(5)$ & $1,46(5)$ & $0,07(5)$ \\
\hline IAC-4 & 12 & $129,9(3)$ & $13,0(3)$ & $41,2(4)$ & $23,3(4)$ & $49,6(4)$ & $150,5(4)$ & $2,42(3)$ & $0,27(2)$ \\
\hline Conquista $\times$ Cristalina & 27 & $138,8(10)$ & $15,6(10)$ & $55,6(1)$ & $116,0(2)$ & $76,1(1)$ & $902,9(2)$ & $3,24(1)$ & $0,45(8)$ \\
\hline Conquista $\times$ Estrela & 27 & $126,5(5)$ & $36,6(9)$ & $48,0(2)$ & $81,3(4)$ & $63,7(3)$ & $618,9(3)$ & $2,85(2)$ & $0,78(1)$ \\
\hline Conquista $\times$ Forrest & 27 & $118,0(3)$ & $113,7(2)$ & $39,6(8)$ & $49,9(7)$ & $36,2(9)$ & $399,9(8)$ & $1,87(7)$ & $0,53(4)$ \\
\hline Conquista $\times$ IAC-4 & 27 & $127,1(6)$ & $58,2(6)$ & $44,4(5)$ & $64,1(5)$ & $52,8(5)$ & $479,7(7)$ & $2,63(4)$ & $0,47(7)$ \\
\hline Cristalina $x$ Estrela & 27 & $133,9(9)$ & $42,5(8)$ & $46,3(4)$ & $118,4(1)$ & $67,6(2)$ & $1044,5(1)$ & $2,63(4)$ & $0,59(3)$ \\
\hline Cristalina $x$ Forrest & 27 & $122,4(4)$ & $122,8(1)$ & $41,1(7)$ & $89,1(3)$ & $44,5(7)$ & $504,9(4)$ & $2,17(6)$ & $0,52(5)$ \\
\hline Cristalina x IAC-4 & 27 & $133,5(8)$ & $59,9(5)$ & $46,7(3)$ & $55,8(6)$ & $60,8(4)$ & $490,5(6)$ & $2,65(3)$ & $0,50(6)$ \\
\hline Estrela $x$ Forrest & 27 & $113,9(1)$ & $49,3(7)$ & $35,6(10)$ & $27,6(10)$ & $38,1(8)$ & $220,2(10)$ & $1,76(8)$ & $0,22(10)$ \\
\hline Estrela $\times$ IAC-4 & 27 & $129,4(7)$ & $63,9(4)$ & $41,5(6)$ & $47,7(8)$ & $51,3(6)$ & $493,4(5)$ & $2,24(5)$ & $0,62(2)$ \\
\hline Forrest $x$ IAC-4 & 27 & $116,3(2)$ & $77,5(3)$ & $36,1(9)$ & $37,2(9)$ & $32,1(10)$ & $243,6(9)$ & $1,76(8)$ & $0,33(9)$ \\
\hline Média genitores & $\begin{array}{c}-- \\
\end{array}$ & 126,0 & 36,5 & 45,6 & 38,4 & 56,4 & 577,1 & 2,50 & 0,24 \\
\hline Média $F_{3: 2}$ & --- & 126,0 & 64,0 & 43,5 & 68,7 & 52,3 & 539,8 & 2,38 & 0,50 \\
\hline Média geral & --- & 126,0 & 54,8 & 44,2 & 58,6 & 53,7 & 552,3 & 2,42 & 0,41 \\
\hline
\end{tabular}

\footnotetext{
${ }^{\mathrm{a}}$ Entre parênteses está a ordem de classificação entre genitores e entre cruzamentos $\mathrm{F}_{2}$.
} 
Tabela 22. Resultado da genotipagem de dez cultivares de soja com cinco marcadores microssatélites (gel de poliacrilamida 6\%) e um marcador RAPD (gel de agarose 1,4\%) ligados a QRLs da PVR, e um marcador microssatélite próximo a QRLs do grupo de ligação $G$.

\begin{tabular}{|c|c|c|c|c|c|c|c|c|c|}
\hline \multirow[b]{2}{*}{ Cultivar } & \multicolumn{6}{|c|}{ Marcadores Ligados a QRLs da PVR } & \multirow{2}{*}{$\begin{array}{l}\text { Número } \\
\text { de QRLs }\end{array}$} & \multirow{2}{*}{$\begin{array}{l}\text { Índice } \\
\text { Aditivo }\end{array}$} & \multirow[b]{2}{*}{ Satt038 ${ }^{1}$} \\
\hline & Satt163 ${ }^{1}$ & Satt309 ${ }^{1}$ & Satt354 ${ }^{2}$ & Satt371 ${ }^{3}$ & Satt570 1 & $\mathrm{OPE} 2_{1000^{1}}$ & & & \\
\hline Forrest & $\mathrm{R}^{4}$ & $\mathrm{R}$ & $\mathrm{S}$ & $S$ & $\mathrm{R}$ & $\mathrm{R}$ & 4 & 64,1 & $\mathrm{R}$ \\
\hline Conquista & $S(?)$ & $S$ & $\mathrm{R}$ & $S$ & $S$ & $\mathrm{R}(?)$ & $1(?)$ & 11,5 & $\mathrm{R}$ \\
\hline IAC-4 & $\mathrm{R}$ & $\mathrm{R}(?)$ & $S(?)$ & $\mathrm{S}(?)$ & $S$ & $\mathrm{R}$ & 2(?) & 28,6 & $\mathrm{R}$ \\
\hline Estrela & $\mathrm{R}$ & S & $\mathrm{S}(?)$ & S & $S$ & $\mathrm{R}(?)$ & $1(?)$ & 16,0 & $\mathrm{~S}$ \\
\hline Cristalina & S & $\mathrm{R}(?)$ & $\mathrm{R}$ & $\mathrm{S}(?)$ & $?$ & $S$ & $1(?)$ & 11,5 & $\mathrm{R}$ \\
\hline SS-1 & $\mathrm{R}$ & $S$ & $\mathrm{R}$ & $S$ & $S$ & $\mathrm{R}$ & 3 & 40,1 & $\mathrm{R}$ \\
\hline IAC-8 & $S(?)$ & $S$ & $\mathrm{R}$ & $S$ & $S$ & $S$ & 1 & 11,5 & $\mathrm{R}$ \\
\hline IAC-8-2 & $\mathrm{S}(?)$ & $S$ & $\mathrm{R}$ & $S$ & $S$ & $S$ & 1 & 11,5 & $S(?)$ \\
\hline Ripley & $\mathrm{R}$ & $S$ & $S(?)$ & $S$ & $S$ & $\mathrm{R}$ & 2 & 28,6 & $\mathrm{R}$ \\
\hline Essex & $S$ & $S$ & $\mathrm{R}$ & $\mathrm{R}$ & $S$ & $S$ & 2 & 23,5 & $S$ \\
\hline
\end{tabular}

\begin{tabular}{|c|c|c|c|c|c|c|c|c|c|c|}
\hline \multicolumn{11}{|c|}{ Variação Fenotípica } \\
\hline Explicada $\left(r^{2}\right)$ & & $16,0^{5}$ & $16,3^{6}$ & $11,5^{6}$ & $12,0^{6}$ & $19,2^{6}$ & $12,6^{6}$ & 6 & 87,6 & - \\
\hline \multirow[t]{2}{*}{ Tamanho (pb) } & Alelos R & 217 & 138 & 250 & 244 & 110 & 1000 & - & - & 175 \\
\hline & Alelos S & 240 & 130 & 236 & 247 & 106 & ausência & - & & 178 \\
\hline
\end{tabular}

Grupo de ligação G.

${ }_{3}^{2}$ Grupo de ligação I.

${ }_{4}^{3}$ Grupo de ligação C2.

${ }^{4}$ R: alelos de resistência; S: alelos de suscetibilidade; ?: alelos de peso molecular diferente (microssatélites) ou banda pouco visível (RAPD).

${ }^{5}$ Segundo Njiti et al. (2002).

${ }^{6}$ Segundo lqbal et al. (2001). 
Tabela 23. Análise de variância (para marcas individuais) para os marcadores Satt163 e Satt354 para a severidade dos sintomas foliares da PVR (aos 40 dias após a emergência), após inoculação pelo método dos grãos de sorgo, em plantas $F_{2}$ do cruzamento das cultivares Conquista x Estrela, no experimento conduzido em telado (TE-JUL01). Soja, Piracicaba-SP.

\begin{tabular}{|c|c|c|c|c|}
\hline & \multicolumn{2}{|r|}{ Satt $163^{a}$} & \multicolumn{2}{|r|}{ Satt354 ${ }^{a}$} \\
\hline & $\mathrm{GL}$ & Quadrado Médio & $\mathrm{GL}$ & Quadrado Médio \\
\hline Genótipos $^{\text {b }}$ & 2 & $0,312317(0,077)$ & 2 & $0,298802(0,084)$ \\
\hline Efeito Aditivo & 1 & $0,339066(0,094)^{c}$ & 1 & $0,228282(0,167)^{\mathrm{C}}$ \\
\hline Efeito de Dominância & 1 & $0,285567(0,124)^{c}$ & 1 & $0,318223(0,104)^{c}$ \\
\hline Resíduo & 123 & 0,119356 & 122 & 0,118376 \\
\hline Total & 125 & - & 124 & - \\
\hline C.V. (\%) & - & 21,5 & - & 21,5 \\
\hline
\end{tabular}

a Os valores entre parênteses referem-se aos níves de probabilidade pelo teste F. Análise com dados transformados para $\sqrt{\mathrm{x}+0,5}$.

${ }^{\mathrm{b}}$ Classes genotípicas com base no marcador: CC, CE e EE.

${ }^{c} \mathrm{SQ}$ e QM obtidas pelos contrastes ortogonais (p. 53).

Tabela 24. Análise de ligação dos marcadores Satt163 e Satt354 para a severidade dos sintomas foliares da PVR (aos 40 dias após a emergência), após inoculação pelo método dos grãos de sorgo, em plantas $\mathrm{F}_{2}$ do cruzamento das cultivares Conquista $x$ Estrela, no experimento conduzido em telado (TE-JUL01). Soja, Piracicaba-SP.

\begin{tabular}{cccccc}
\hline & & \multicolumn{3}{c}{ Média de Severidade (1 a 5) } \\
\cline { 4 - 6 } Marcador & Probabilidade & $\mathrm{r}^{2}(\%)$ & $\mathrm{CC}(\mathrm{n})^{1}$ & $\mathrm{CE}(\mathrm{n})$ & $\mathrm{EE}(\mathrm{n})$ \\
\hline Satt163 & 0,077 & 4,1 & $2,31(27) \mathrm{a}$ & $2,33(72) \mathrm{a}$ & $1,76(27) \mathrm{a}$ \\
Satt354 & 0,084 & 4,0 & $2,21(26) \mathrm{a}$ & $2,37(66) \mathrm{a}$ & $1,82(33) \mathrm{a}$ \\
\hline
\end{tabular}

'C: alelo de 'Conquista'; E: alelo de 'Estrela'; n: número de indivíduos.

* Em cada linha (marcador), médias seguidas de mesma letra não diferem entre si, a $5 \%$ de probabilidade, pelo teste de Tukey-Kramer. Dados transformados para $\sqrt{\mathrm{x}+0,5}$. 
Tabela 25. Tabela de contingência entre a severidade dos sintomas foliares da PVR e a classificação com base nos marcadores Satt163 e Satt354 e eficiência de seleção.

\begin{tabular}{|c|c|c|c|c|c|}
\hline \multirow{2}{*}{\multicolumn{2}{|c|}{$\begin{array}{c}\text { Classificação com base } \\
\text { nos Marcadores }\end{array}$}} & \multicolumn{2}{|c|}{ Avaliação Fenotípica $^{1}$} & \multicolumn{2}{|c|}{ Número de Indivíduos } \\
\hline & & Resistentes & Suscetíveis & Observado & Esperado $^{2}$ \\
\hline \multirow{4}{*}{ Satt163 } & Resistentes & $22[17,5 \%]^{3}$ & 05 & 27 & $31,5(1)$ \\
\hline & Suscetíveis & 57 & $42[33,3 \%]$ & 99 & $94,5(3)$ \\
\hline & Total & 79 & 47 & 126 & $126,0^{(0,36) 4}$ \\
\hline & \multicolumn{3}{|c|}{ Eficiência de Seleção } & $50,8 \%$ & - \\
\hline \multirow{4}{*}{ Satt354 } & Resistentes & $26[20,8 \%]$ & 07 & 33 & $31,2(1)$ \\
\hline & Suscetíveis & 53 & $39[31,2 \%]$ & 92 & $93,8(3)$ \\
\hline & Total & 79 & 46 & 125 & $125,0^{(0,72)}$ \\
\hline & \multicolumn{3}{|c|}{ Eficiência de Seleção } & $52,0 \%$ & - \\
\hline
\end{tabular}

${ }^{1}$ Indivíduos com nota de severidade dos sintomas foliares inferior ou igual a dois foram considerados resistentes e, superior a dois, suscetíveis.

${ }^{2}$ Valores entre parênteses indicam as proporções esperadas considerando-se dois alelos por loco e a resistência como caráter recessivo.

3 Valores entre colchetes correspondem a porcentagem em relação ao número total de indivíduos (p. ex.: 22/126=17,5\%).

${ }^{4}$ Probabilidade de que os desvios entre as freqüências observadas e esperadas sejam devidos ao acaso, pelo teste de qui-quadrado. 


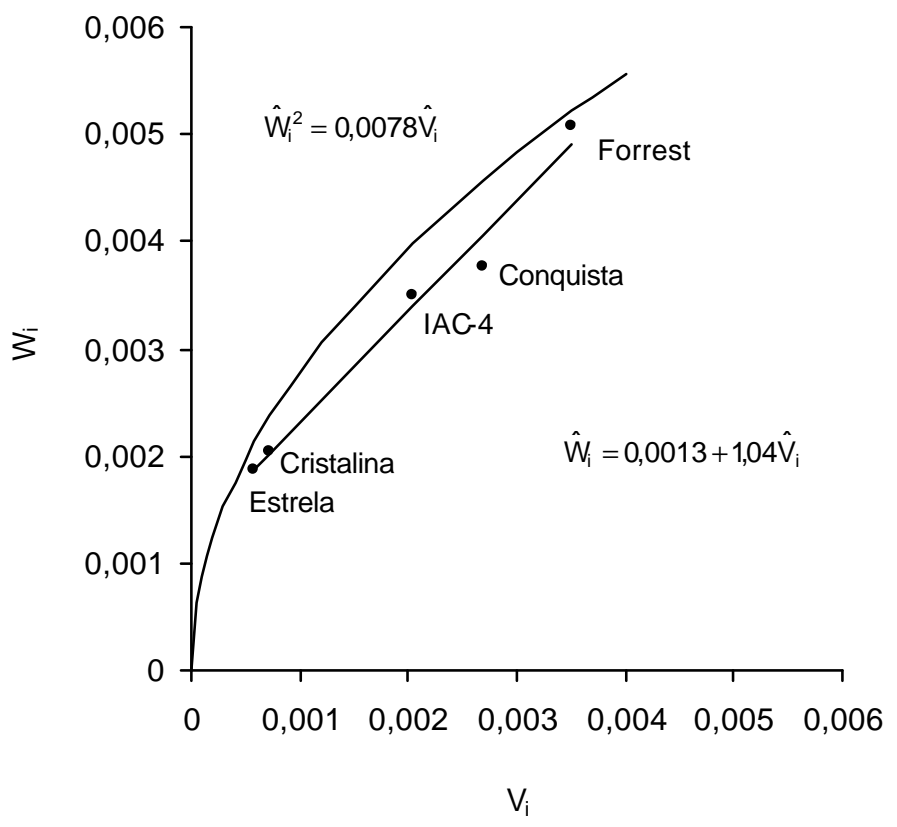

Figura 1 - Regressão de $W_{i}$ em função de $V_{i}$ para a severidade dos sintomas foliares (SF) da PVR, no experimento conduzido em telado (TE-JUL01).

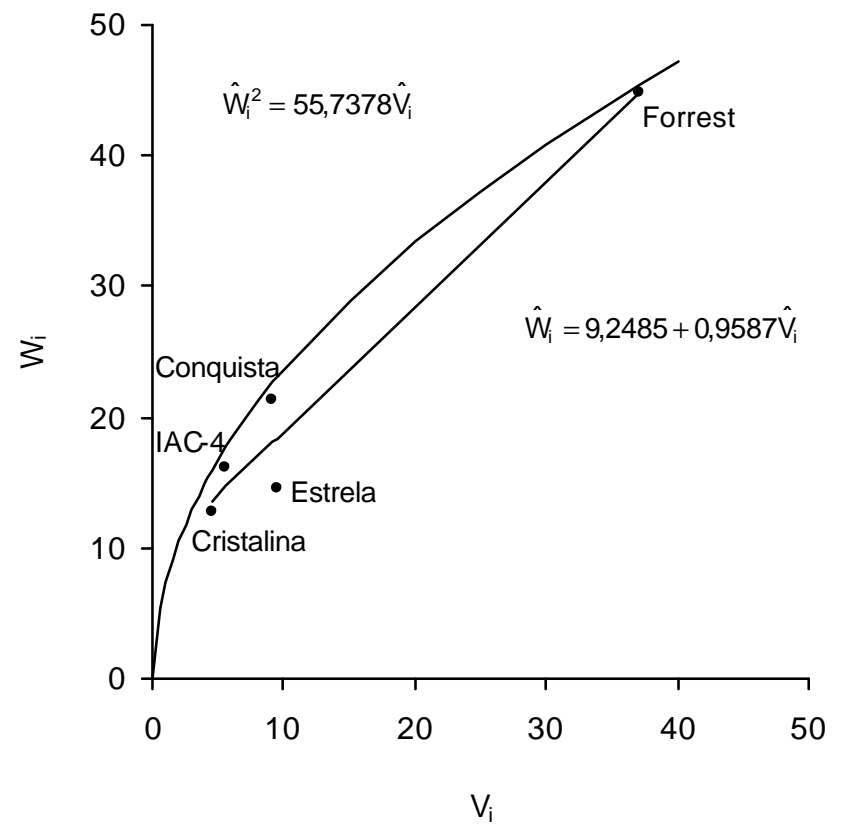

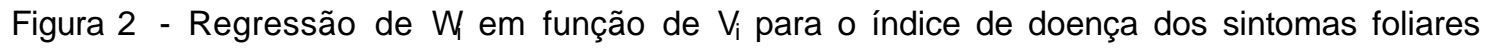
(IDF) da PVR, no experimento conduzido em telado (TE-JUL01). 


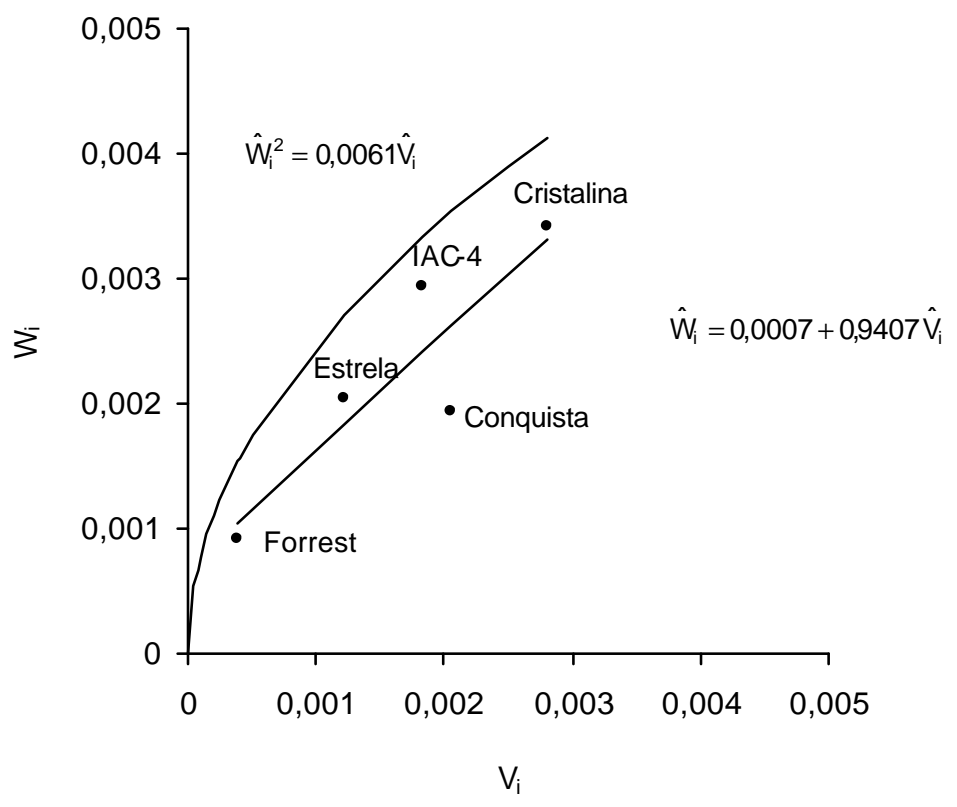

Figura 3 - Regressão de $W_{i}$ em função de $V_{i}$ para a severidade dos sintomas foliares (SF) da PVR, no experimento conduzido em casa de vegetação (CV-SET01).

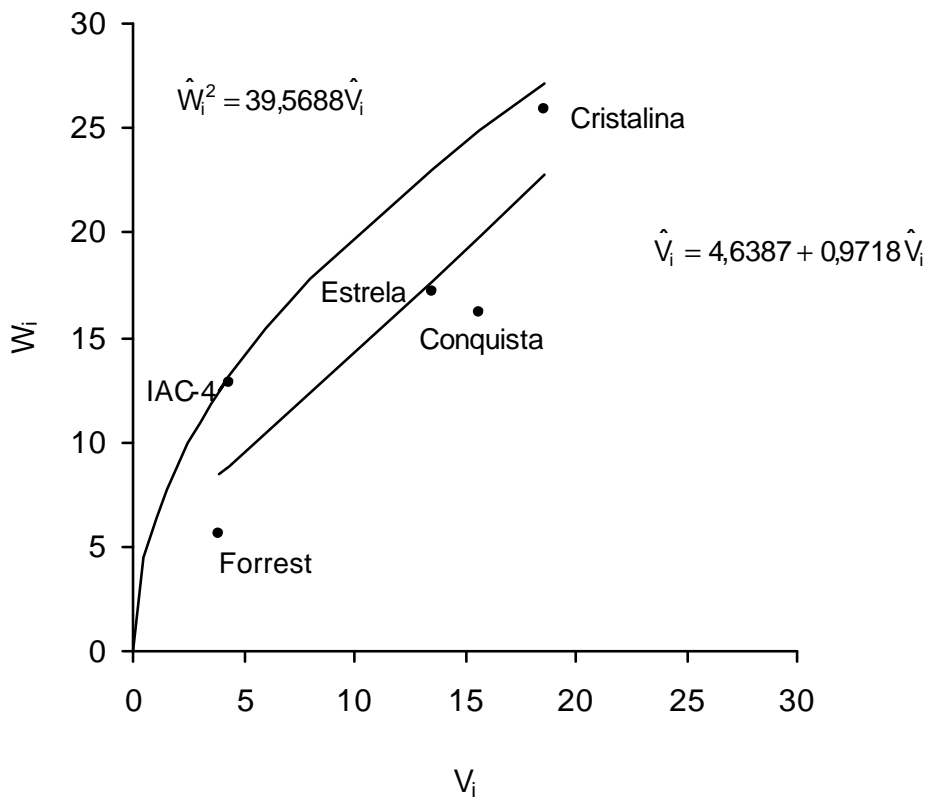

Figura 4 - Regressão de $W$ em função de $V_{i}$ para $o$ índice de doença dos sintomas foliares (IDF) da PVR, no experimento conduzido em casa de vegetação (CV-SET01). 


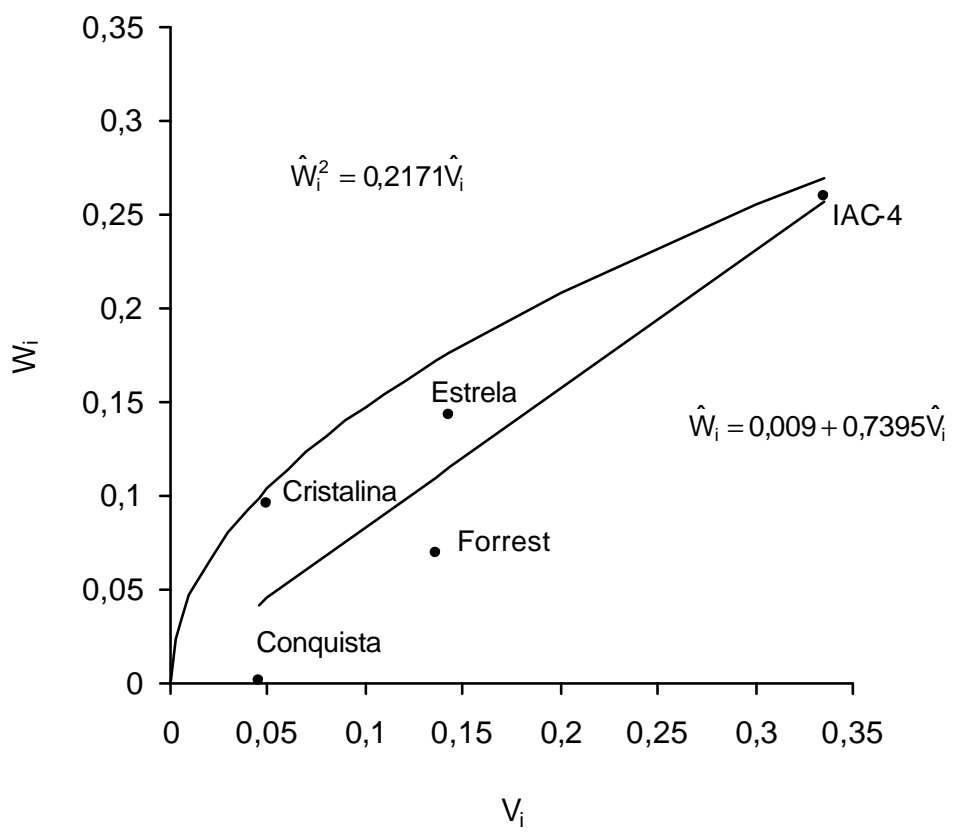

Figura 5 - Regressão de $W_{i}$ em função de $V_{i}$ para a severidade dos sintomas foliares (SF) da PVR, no experimento conduzido em casa de vegetação,(CV-JUL02).

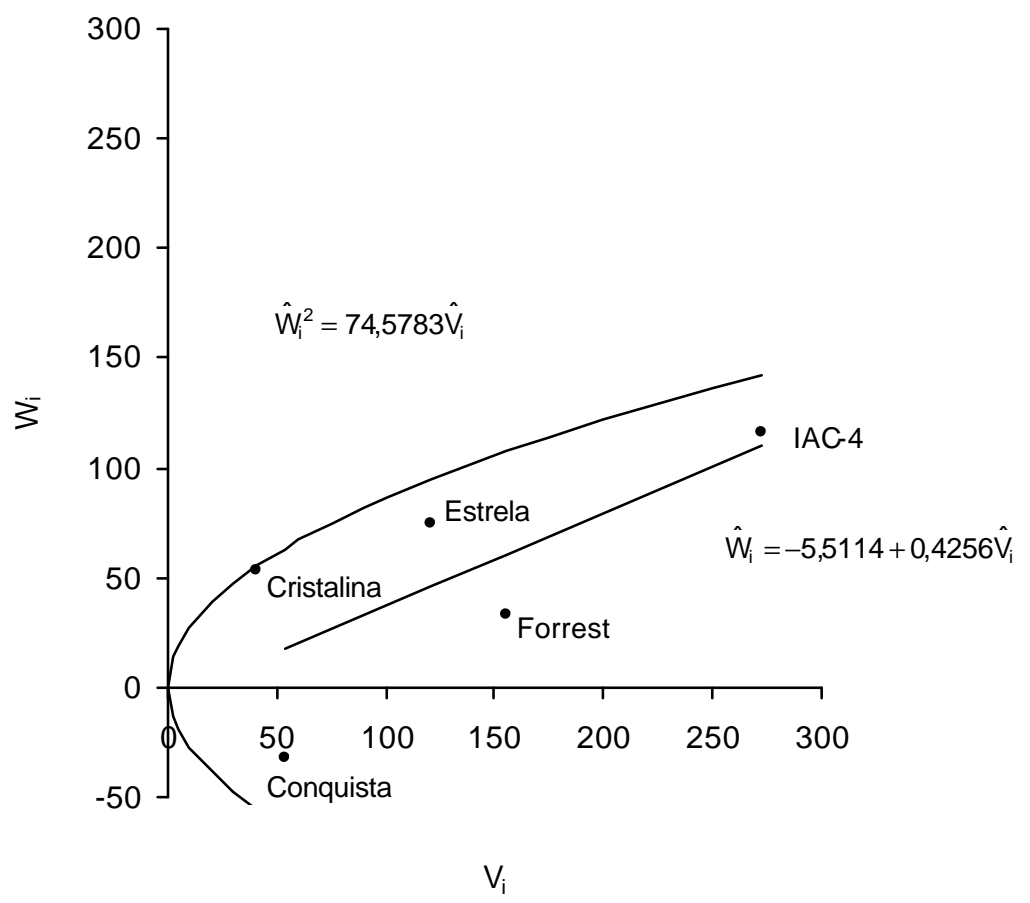

Figura 6 - Regressão de $W$ em função de $V_{i}$ para o índice de doença dos sintomas foliares (IDF) da PVR, no experimento conduzido em casa de vegetação (CV-JUL02). 


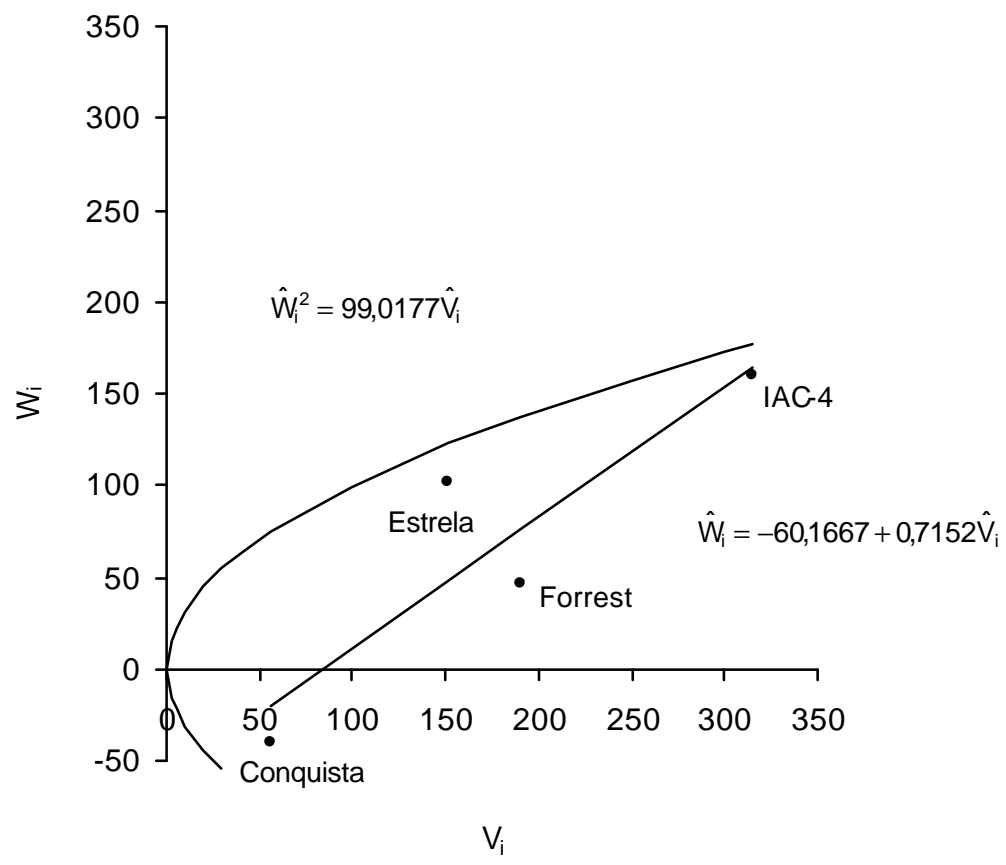

Figura 7 - Regressão de $W$ em função de $V_{i}$ para o índice de doença dos sintomas foliares (IDF) da PVR, sem o genitor 'Cristalina', no experimento conduzido em casa de vegetação (CV-JUL02).

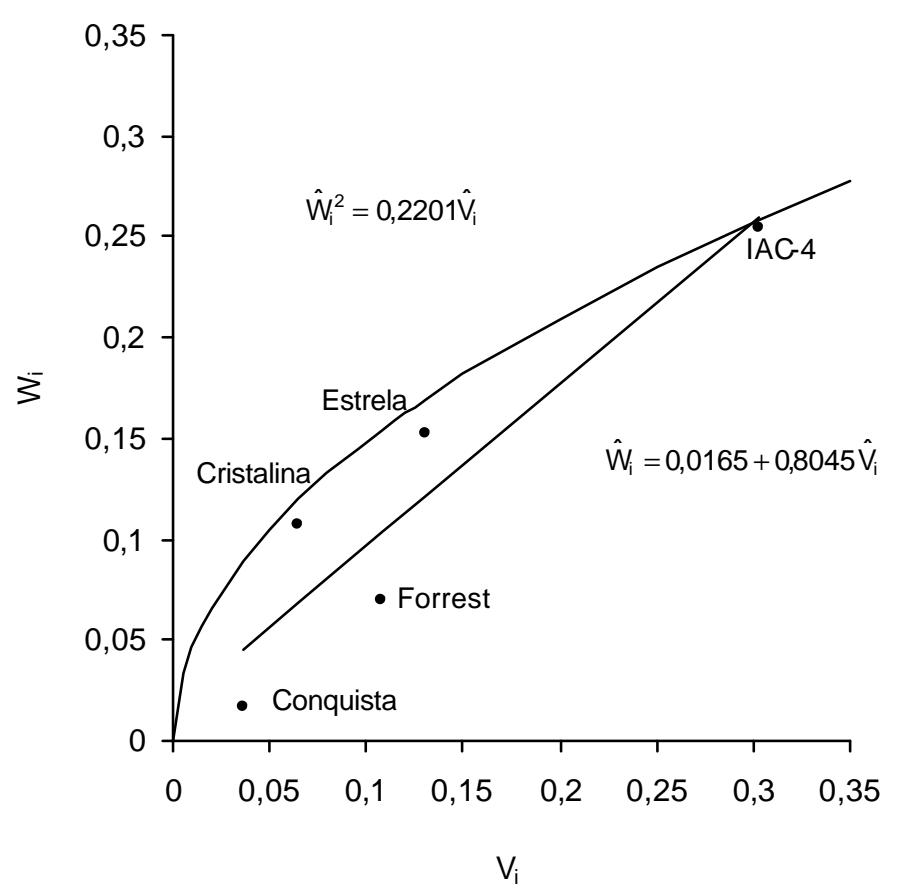

Figura 8 - Regressão de $W_{i}$ em função de $V_{i}$ para a severidade dos sintomas foliares (SP) da PVR, no experimento conduzido em casa de vegetação (CV-JUL02). 


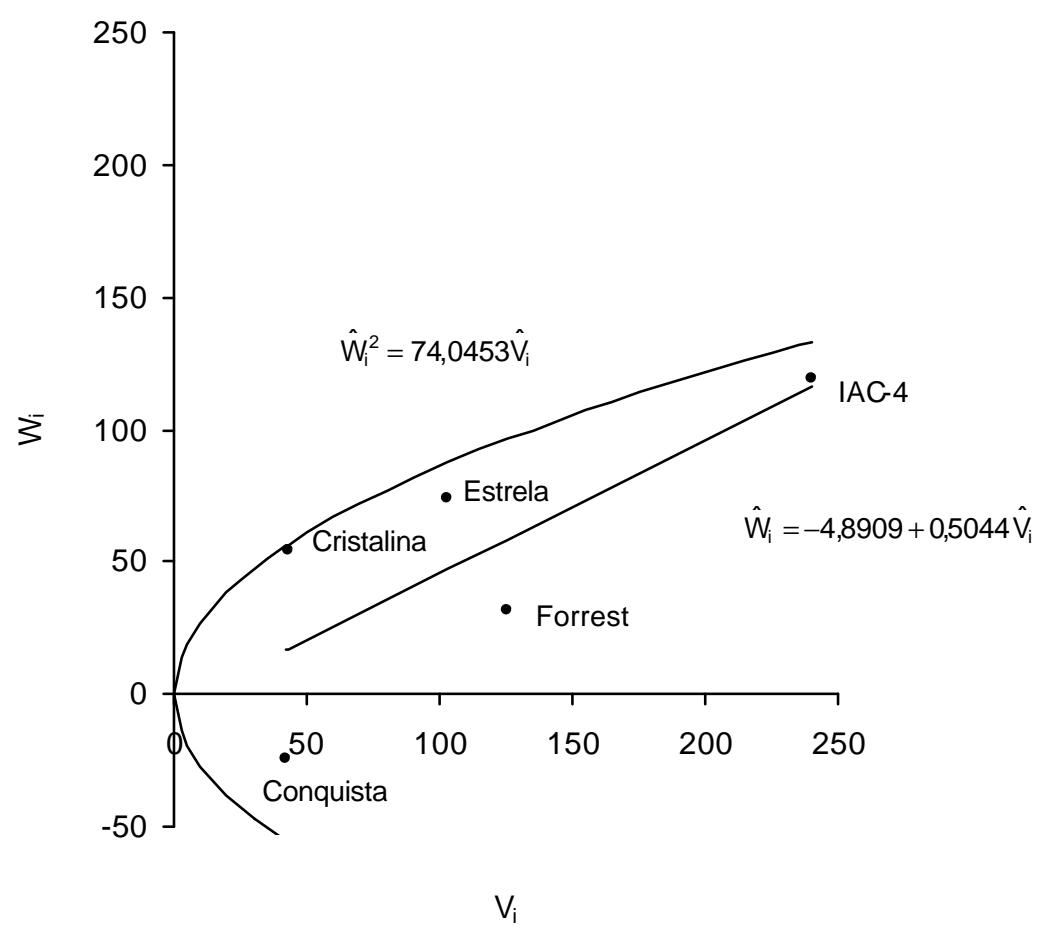

Figura 9 - Regressão de $W$ em função de $V_{i}$ para $o$ índice de doença dos sintomas foliares (IDP) da PVR, no experimento conduzido em casa de vegetação (CV-JUL02).

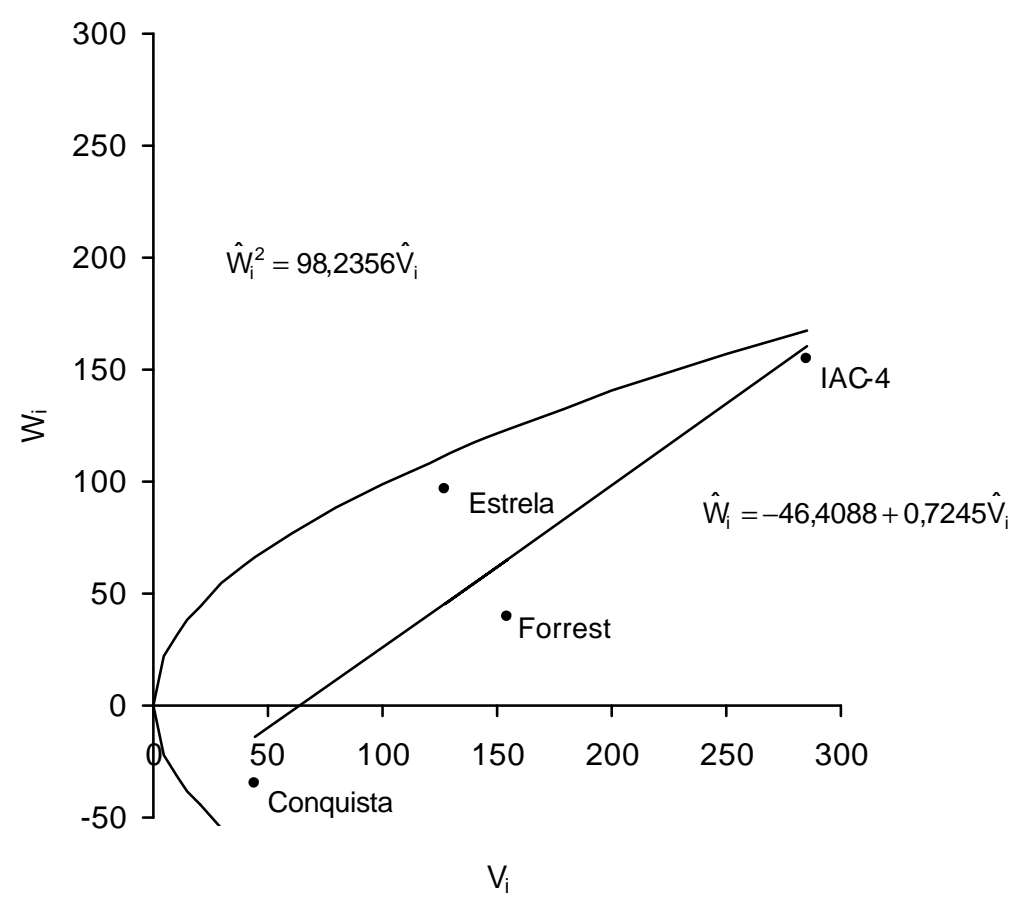

Figura 10 - Regressão de $W_{i}$ em função de $V_{i}$ para $o$ índice de doença dos sintomas foliares (IDP) da PVR, sem o genitor 'Cristalina', no experimento conduzido em casa de vegetação (CV-JUL02). 


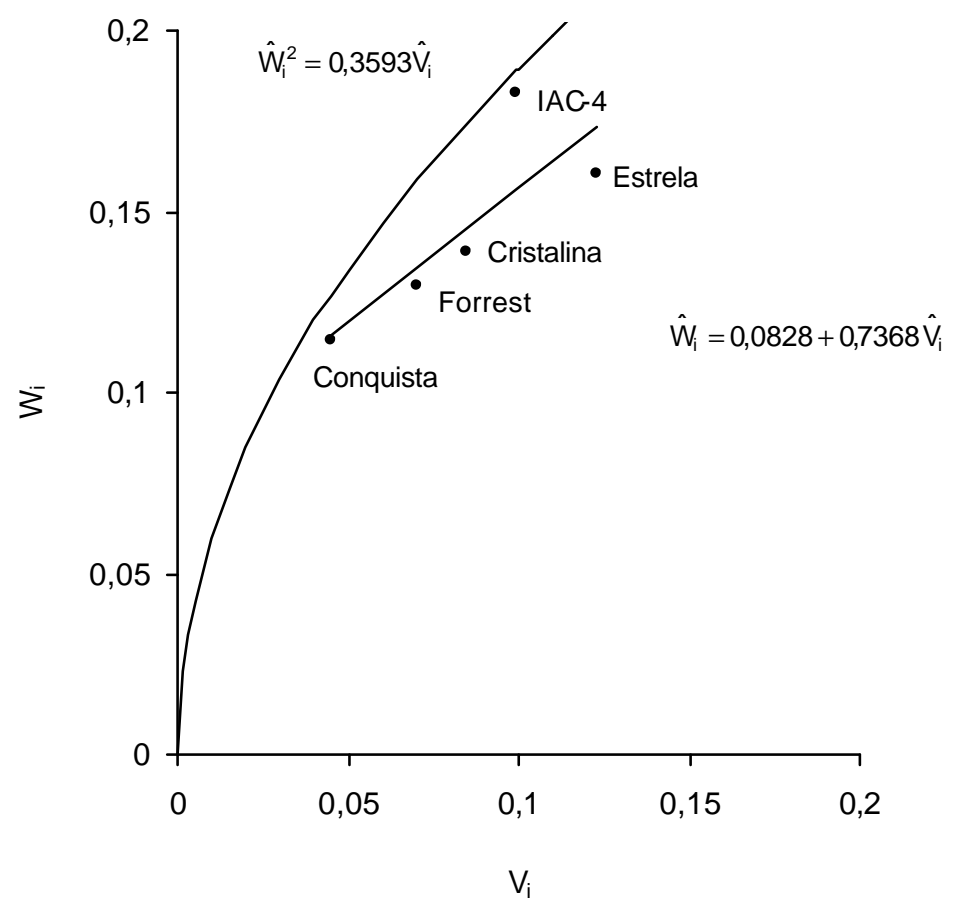

Figura 11 - Regressão de $W_{i}$ em função de $V_{i}$ para a severidade dos sintomas foliares da PVR desconsiderando as plantas com nota 1 (SP1), no experimento conduzido em casa de vegetação (CV-JUL02). 

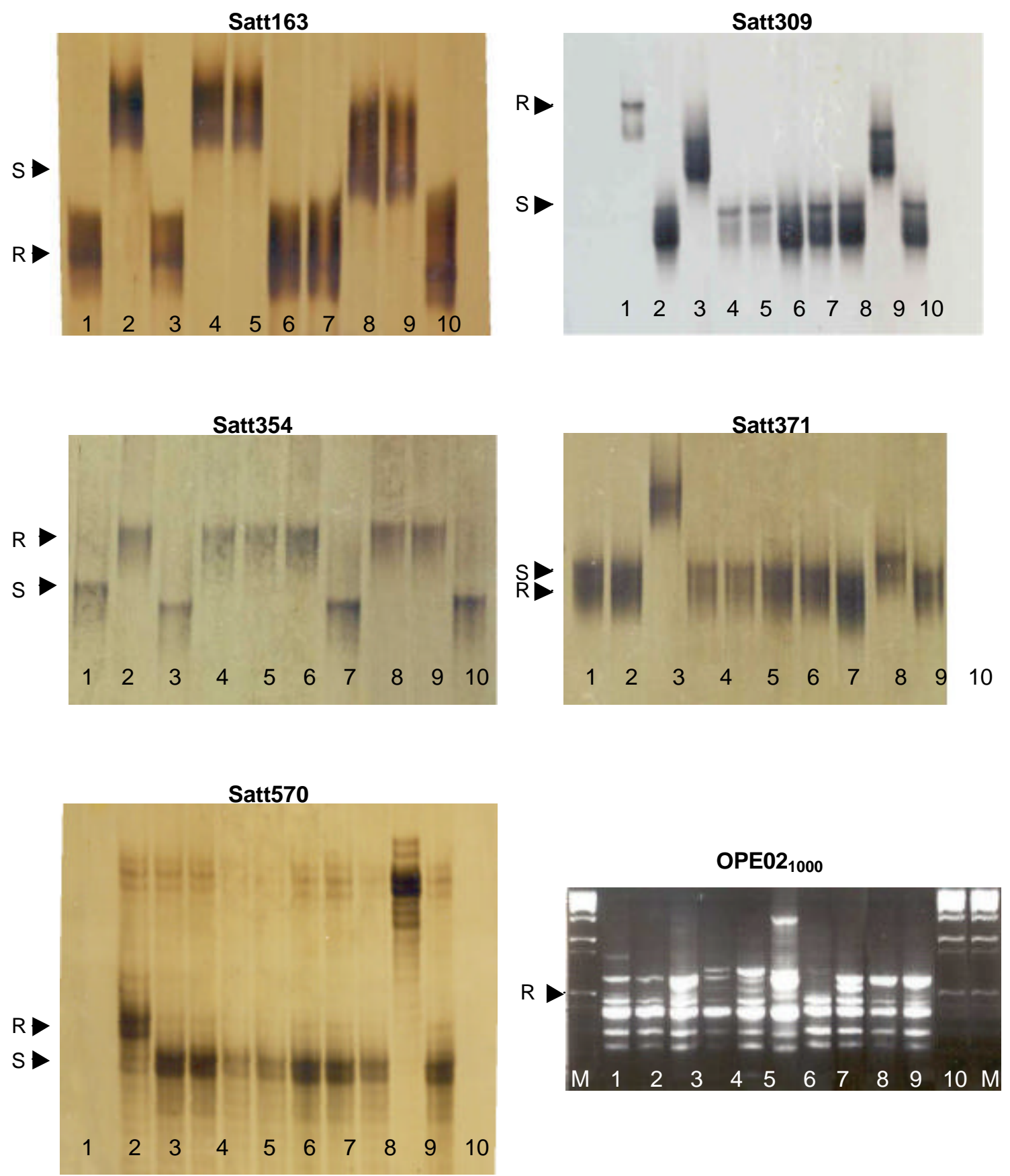

Figura 12 - Perfil de eletroforese com os marcadores moleculares microssatélites Satt163, Satt309, Satt354, Satt371 e Satt570, em poliacrilamida 6\%, e RAPD OPE02 ${ }_{1000}$, em agarose 1,4\% (1: Forrest, 2: Conquista, 3: IAC-4, 4: IAC-8, 5: IAC-8-2, 6: SS-1, 7: Estrela, 8: Essex, 9: Cristalina, 10: Ripley e M: marcador de peso molecular. R: posição dos alelos de resistência e S: posição dos alelos de suscetibilidade). 


\section{REFERÊNCIAS BIBLIOGRÁFICAS}

ABU-THREDEIH, J.; CHANG, S.J.C.; DOUBLER, T.W.; LIGHTFOOT, D.A. Integration of SDS, SCN race 3 and SCN race 14 resistance QTL with the soybean genome map. Soybean Genetics Newsletter, v.23, p.158-162, 1996.

ACHENBACH, L.A.; PATRICK, J.; GRAY, L. Use of RAPD markers as a diagnostic tool for the identification of Fusarium solani isolates that cause soybean sudden death syndrome. Plant Disease, v.80, p.1228-1232, 1996.

ACHENBACH, L.A.; PATRICK, J.; GRAY, L. Genetic homogeneity among isolates of Fusarium solani that cause soybean sudden death syndrome. Theoretical and Applied Genetics, v.95, p.474-478, 1997.

ALLIPRANDINI, L.F. Potencialidade de cruzamentos quádruplos de soja com ênfase na produtividade de grãos. Piracicaba, 1996. 174p. Tese (Doutorado) - Escola Superior de Agricultura "Luiz de Queiroz", Universidade de São Paulo.

AMARAL JÚNIOR, A.T.; CASALI, V.W.D.; CRUZ, C.D.; FINGER, F.L. Inferências genéticas na produção e qualidade de tomateiro sob cruzamento dialélico. Pesquisa Agropecuária Brasileira, v.34, n.8, p.1407-1416, 1999.

ANDERSON, T.R. First report of Fusarium solani f.sp. glycines causing sudden death syndrome of soybean in Canada. Plant Disease, v.82, p.448, 1998. /Abstract/

ARIAS, C.A.A.; TOLEDO, J.F.F.; OLIVEIRA, M.F.; BROGIN, R.L. Genética quantitativa das características de interesse do melhoramento - previsão e exploração do potencial genético da soja. In: EMPRESA BRASILEIRA DE PESQUISA AGROPECUÁRIA. Resultados de Pesquisa da Embrapa Soja 1998. Londrina: Embrapa Soja, 1999. p.156-161. 
ARUNACHALAM, V. Evaluation of diallel crosses by graphical and combining ability methods. Indian Journal of Genetics \& Plant Breeding, v.36, n.3, p.358-366,1976.

BAKER, R.J. Issues in diallel analysis. Crop Science, v.18, p.533-536, 1978.

BALARDIN, R.S.; RUBIN, S.A.L. Reação de germoplasma de soja à Fusarium solani f.sp. glycines. In: CONGRESSO BRASILEIRO DE SOJA, Londrina, 1999. Anais. Londrina: Embrapa Soja, 1999. p.461.

BARRIGA B., P. Acción génica de las áreas fotosintéticas ubicadas sobre el nudo de la hoja bandera en trigo de primavera. Agro Sur, v.7, n.1, p.19-22, 1979.

BELL-JOHNSON, B.; GARVEY, G.; JOHNSON, J.; LIGHTFOOT, D.; MEKSEM, K. Biotechnology approaches to improving resistance to SCN and SDS: methods for high throughput marker assisted selection. Soybean Genetics Newsletter, v.25, p.115-117, 1998.

BONATO, E.R. Herança do tempo para o florescimento e para a maturidade em variantes naturais de soja [Glycine max (L.) Merrill]. Piracicaba, 1989. 166p. Tese (Doutorado) Escola Superior de Agricultura "Luiz de Queiroz", Universidade de São Paulo.

CHANG, S.J.C.; DOUBLER, T.W.; KILO, V.; ABU-THREDEIH, J.; PRABHU, R.; FREIRE, V.; SUTTNER, R.; KLEIN, J.; SCHMIDT, M.E.; GIBSON, P.T.; LIGHTFOOT, D.A. Association of loci underlying field resistance to soybean sudden death syndrome (SDS) and cyst nematode (SCN) race 3. Crop Science, v.37, p.965-971, 1997.

CHANG, S.J.C.; DOUBLER, T.W.; KILO, V.; SUTTNER, R.; KLEIN, J.; SCHMIDT, M.E.; GIBSON, P.T.; LIGHTFOOT, D.A. Two additional loci underlying durable field resistance to soybean sudden death syndrome (SDS). Crop Science, v.36, p.1684-1688, 1996.

CHAUBEY, C.N.; SENADHIRA, D.; GREGORIO, G.B. Genetics analysis of tolerance for phosphorus deficiency in rice (Oriza sativa L.). Theorethical and Applied Genetics, v.89, p.313-317, 1992.

COSTA, C.L.; YORINORI, J.T. Métodos de inoculação de Fusarium solani para avaliação de resistência em soja. Fitopatologia Brasileira, v.20, p.332, 1995a. Suplemento. /Resumo/ 
COSTA, C.L.; YORINORI, J.T. Reação de cultivares de soja à podridão vermelha da raiz (PVR) (Fusarium solani), avaliada pelo método do palito. Fitopatologia Brasileira, v.20, p.332, 1995b. Suplemento. /Resumo/

COSTA, C.L.; YORINORI, J.T. Variabilidade morfológica e patologia de isolados de Fusarium solani associados à podridão vermelha da raiz em soja. In: REUNIÃO DE PESQUISA DE SOJA DA REGIÃO CENTRAL DO BRASIL, 18., Uberlândia, 1996. Ata e resumos. Uberlândia: UFU, DEAGO, 1997. p.321-322. /Resumo/

CREGAN, P.B.; JARVICK, T.; BUSH, A.L.; SHOEMAKER, R.C.; LARK, K.G.; KAHLER, A.L.; KAYA, N.; van TOAI, T.T.; LOHNES, D.G.; CHUNG, J.; SPECHT, J.E. An integrated genetic linkage map of the soybean genome. Crop Science, v.39, p.1464-1490, 1999.

CRUMPACKER, D.W.; ALLARD, R.W. A diallel cross analysis of heading date in wheat. Hilgardia, v.32, n.6, p.275-318, 1962.

CRUZ, C.D. Programa Genes: versão Windows; aplicativo computacional em genética e estatística. Viçosa: UFV, 2001. 648p.

CRUZ, C.D.; REGAZZI, A.J. Modelos biométricos aplicados ao melhoramento genético. 2.ed. Viçosa: UFV, 1997. 390p.

DAVID, H.A. Upper 5 and $1 \%$ points of the maximum F-ratio. Biometrika, v.39, p.422-424, 1952.

DOUBLER, T.W.; SUTTNER, B.; CHANG, S.J.C.; GIBSON, P.T.; LIGHTFOOT, D.A. Qualitative inheritance of quantitative trait loci. Soybean Genetics Newsletter, v.24, p.139-141, 1997.

EATHINGTON, S.R.; LIM, S.M.; NICKELL, C.D.; PATAKY, J.K.; ESGAR, R.W. Disease pressure in Illinois. Plant Disease, v.77, p.1136-1139, 1993.

EMPRESA BRASILEIRA DE PESQUISA AGROPECUÁRIA. Tecnologias de produção de soja: região Central do Brasil - 2001/2002. Londrina: Embrapa Soja, 2001. 267p. 
FARIAS NETO, A.L.; SOUZA, P.I.M., MOREIRA, C.T.; OLIVEIRA, A.B. Avaliação de genótipos de soja quanto a resistência à podridão vermelha da raiz (Fusarium solani f.sp. glycines) (compact disc). In: CONGRESSO BRASILEIRO DE MELHORAMENTO DE PLANTAS, 1., Goiânia, 2001. Anais. Goiânia: UFG/Embrapa Arroz e Feijão/AGENCIARURAL, 2001. /Area1-Resumo104/

FERREIRA, P.E. On Jinks-Hayman's analysis of half diallels. Brazilian Journal of Genetics, v.8, n.1, p.149-155, 1985.

FERREIRA, P.E. A new look at Jinks-Hayman's method for the estimation of genetical components in diallel crosses. Heredity, v.60, p.347-353, 1988.

FERREIRA, M.E.; GRATTAPAGLIA, D. Introdução ao uso de marcadores moleculares em análise genética. 3.ed. Brasília: EMBRAPA, CENARGEN, 1998. 220p.

FREIRE FILHO, F.R. Análise genética de um dialelo entre genótipos precoces de soja [Glycine $\max ($ L.) Merrill]. Piracicaba, 1988. 224p. Tese (Doutorado) - Escola Superior de Agricultura "Luiz de Queiroz", Universidade de São Paulo.

GARCIA, A.A.F.; BARBIN, D.; PIEDADE, S.M.S. LCE 602 - estatística experimental (aulas práticas). http://ce.esalq.usp.br/dce/augusto2/augusto/estexp.htm (08 jan. 2002)

GARDNER, C.O.; EBERHART, S.A. Analysis and interpretation of the variety cross diallel and related populations. Biometrics, v.22, p.439-452, 1966.

GÁSPERI, A.C. Variabilidade de isolados, reação de cultivares e danos causados por Fusarium solani f.sp. glycines em soja. Passo Fundo, 2000. 91p. Dissertação (Mestrado) - Faculdade de Agronomia e Medicina Veterinária, Universidade de Passo Fundo.

GOMES, R.L.F. Análise genética de progênies $F_{6}$ e $F_{7: 6}$ de soja obtidas de cruzamentos dialélicos. Piracicaba, 1995. 140p. Tese (Doutorado) - Escola Superior de Agricultura "Luiz de Queiroz", Universidade de São Paulo.

GRAY, L.E.; ACHENBACH, L.A. Severity of foliar symptoms and root crown rot of soybean inoculated with various isolates and inoculum rates of Fusarium solani. Plant Disease, v.80, p.1197-1199, 1996. 
GRIFFING, B. Concept of general and specific combining ability in relation to diallel crossing systems. Australian Journal of Biological Science, v.9, p.463-493, 1956.

HARTMAN, G.L.; HUANG, Y.H.; NELSON, R.L.; NOEL, G.R. Germplasm evaluation of Glycine max for resistance to Fusarium solani, the causal organism of sudden death syndrome. Plant Disease, v.81, p.515-518, 1997.

HAYMAN, B.I. The theory and analysis of diallel crosses. Genetics, v.39, p.789-809, 1954a.

HAYMAN, B.I. The analysis of variance of diallel tables. Biometrics, v.10, p.235-244, 1954b.

HAYMAN, B.I. The theory and analysis of diallel crosses. II. Genetics, v.43, p.63-85, 1958.

HAYMAN, B.I. The theory an analysis of diallel crosses. III. Genetics, v.45, p.156-172, 1960.

HEAVNER, D.L.; NICKELL, C.D.; KOLB, F.L. Genetic analysis of the response of the soybean cultivar Asgrow A4715 to Fusarium solani. Soybean Genetics Newsletter, v.23, p.144-148, 1996.

HERSHMAN, D.E.; HENDRIX, J.W.; STUCKEY, R.E.; BACHI, P.R.; HENSON, G. Influence of planting date and cultivar on soybean sudden death syndrome in Kentucky. Plant Disease, v.74, p.761-766, 1990.

HILL, J.; WAGOIRE, W.W.; ORTIZ, R.; STØLEN, O. Analysis of a combined $F_{1} / F_{2}$ diallel cross in wheat. Theorethical and Applied Genetics, v.102, p.1076-1081, 2001.

HNETKOVSKY, N.; CHANG, S.J.C.; DOUBLER, T.W.; GIBSON, P.T.; LIGHTFOOT, D.A. Genetic mapping of loci underlying field resistance to soybean sudden death syndrome (SDS). Crop Science, v.36, p.393-400, 1996.

HUANG, Y.H.; HARTMAN, G.L. Reaction of selected soybean genotypes to isolates of Fusarium solani f.sp. glycines and their culture filtrates. Plant Disease, v.82, p.999-1002, 1998.

IQBAL, J. Sequence of primer Satt214. mjiqbal@siu.edu (05 Nov. 2001) 
IQBAL, M.J.; MEKSEM, K.; NJITI, V.N.; KASSEM, M.A.; LIGHTFOOT, D.A. Microsatellite markers identify three additional quantitative trait loci for resistance to soybean sudden-death syndrome (SDS) in Essex x Forrest RILs. Theorethical and Applied Genetics, v.102, p.187-192, 2001.

JARDINE, D.J.; RUPE, J.C. First report of soybean sudden death syndrome of soybean caused by Fusarium solani in Kansas. Plant Disease, v.77, p.1264, 1993. /Abstract/

JIN, H.; HARTMAN, G.L.; NICKELL, C.D.; WIDHOLM, J.M. Characterization and purification of a phytotoxin produced by Fusarium solani, the causal agent of sudden death syndrome of soybean. Phytopathology, v.86, n.3, p.277-282, 1996a.

JIN, H.; HARTMAN, G.L.; NICKELL, C.D.; WIDHOLM, J.M. Phytotoxicity of culture filtrate from Fusarium solani, the causal agent of sudden death syndrome of soybean. Plant Disease, v.80, p.922-927, 1996b.

JINKS, J.L. The analysis of continuous variation in a diallel cross of Nicotiana rustica varieties. Genetics, v.39, p.767-788, 1954.

JINKS, J.L. The $F_{2}$ and backcross generations from a set of diallel crosses. Heredity, v.10, p.130, 1956.

JINKS, J.L.; HAYMAN, B.I. The analysis of diallel crosses. Maize Genetics Cooperation News Letter, v.27, p.48-54, 1953.

JONES, R.M. Analysis of variance of the half diallel table. Heredity, v.20, p.117-121, 1965.

JONES, J.L.; GUPTON, C.L.; TERRILL, T.R. Inheritance of resistance to isolates of Fusarium oxysporum var. batatas in burley tobacco. Crop Science, v.12, p.522-525, 1972.

KAO, C.-H.; ZENG, Z.-B.; TEASDALE, R.D. Multiple interval mapping for quantitative trait loci. Genetics, v.152, p.1203-1216, 1999.

KEMPTHORNE, O. The theory of the diallel cross. Genetics, v.41, p.451-459,1956. 
KILLEBREW, J.F.; ROY, K.W.; LAWRENCE, G.W.; McLEAN, K.S.; HODGES, H.H. Greenhouse and field evaluation of Fusarium solani pathogenicity to soybean seedlings. Plant Disease, v.72, p.1067-1070, 1988.

KILO, V.; ABU-THREDEIH, J.; SUTTNER, B.; CHANG, S.J.C.; GIBSON, P.T.; LIGHTFOOT, D.A. Coinheritance of resistance to SCN and SDS in Pyramid $x$ Douglas. Soybean Genetics Newsletter, v.24, p.126-127, 1997.

KLINGELFUSS, L.H.; DESTRO, D.; ARIAS, C.A.A.; YORINORI, J.T. Resposta de genótipos de soja à síndrome da morte súbita (compact disc). In: CONGRESSO BRASILEIRO DE MELHORAMENTO DE PLANTAS, 1., Goiânia, 2001. Anais. Goiânia: UFG/Embrapa Arroz e Feijão/AGENCIA RURAL, 2001a. /Area1-Resumo195/

KLINGELFUSS, L.H.; YORINORI, J.T.; DESTRO, D.; ARIAS, C.A.A. Resposta de genótipos de soja à síndrome da morte súbita. In: REUNIÃO DE PESQUISA DE SOJA DA REGIÃO CENTRAL DO BRASIL, 23., Londrina, 2001. Resumos. Londrina: Embrapa Soja, 2001b. p.113-114.

LANDE, R.; THOMPSON, R. Efficiency of marker-assisted selection in the improvement of quantitative traits. Genetics, v.124, p.743-756, 1990.

LANDER, E.S.; BOTSTEIN, D. Mapping Mendelian factors underlying quantitative traits using RFLP linkage maps. Genetics, v.121, p.185-199, 1989.

LEÃO, R.Z.R.; FREITAS, M.A.; CAFÉ FILHO, A.C. Reação de cultivares de soja à inoculação com isolados de diferentes espécies e formae speciales de Fusarium. Summa Phytopathologica, v.24, n.3/4, p.268-271, 1998.

LI, S.; HARTMAN, G.L.; GRAY, L.E. Chlamydospore formation, production, and nuclear status in Fusarium solani f.sp. glycines soybean sudden death syndrome-causing isolates. Mycologia, v.90, n.3, p.414-421, 1998.

LIM, S.M. A technique for inoculating soybeans in the greenhouse with Fusarium solani. Phytopathology, v.81, p.1238, 1991. /Abstract/ 
LIM, S.M.; SONG, H.S.; GRAY, L.E. Phytotoxicity of culture filtrates from Fusarium solani isolated from soybean. Phytopathology, v.80, p.1044, 1990. /Abstract/

LINCOLN, S.E.; DALY, M.J.; LANDER, E.S. MAPMAKER/EXP version $\mathbf{3 . 0}$ (software). Cambridge: Whitehead Institute for Biomedical Research/Massachussetts Institute of Technology, 1992.

LOPES, A.C.A. Análise dialélica envolvendo genótipos parentais de soja resistentes ao nematóide de cisto. Piracicaba, 2001. 122p. Tese (Doutorado) - Escola Superior de Agricultura "Luiz de Queiroz", Universidade de São Paulo.

LUO, Y.; MYERS, O.; LIGHTFOOT, D.A.; SCHMIDT, M.E. Root colonization of soybean cultivars in the field by Fusarium solani f.sp. glycines. Plant Disease, v.83, p.1155-1159, 1999.

MARTINS FILHO, S.M. Mancha olho-de-rã da soja: análise genética da resistência e identificação de marcadores moleculares. Viçosa, 1999. 59p. Tese (Doutorado) Universidade Federal de Viçosa.

MATHER, K.; JINKS, J.L. Introdução à genética biométrica . Ribeirão Preto: Sociedade Brasileira de Genética, 1984. 242p.

MATHER, K.; JINKS, J.L. Biometrical genetics: the study of continuous variation. 3.ed. Londres: Chapman and Hall, 1982. 396p.

McLEAN, K.; LAWRENCE, G.W. Interrelationship of Heterodera glycines and Fusarium solani in sudden death syndrome of soybean. Journal of Nematology, v.25, n.3, p.434-439, 1993.

McPHEE, K.E.; ZEMETRA, R.S.; BROWN, J.; MYERS, JR. Genetic analysis of the raffinose family oligosaccharides in common bean. Journal of the American Society for Horticultural Science, v.127, n.3, p.376-382, 2002.

MEKSEM, K.; DOUBLER, T.W.; CHANCHAROENCHAI, K.; NJITI, V.N.; CHANG, S.J.C.; RAO ARELLI, A.P.; CREGAN, P.E.; GRAY, L.E.; GIBSON, P.T.; LIGHTFOOT, D.A. Clustering among loci underlying soybean resistance to Fusarium solani, SDS and NCS in near-isogenic lines. Theorethical and Applied Genetics, v.99, p.1131-1142, 1999a. 
MEKSEM, K.; HYTEN, D.; CHANCHAROENCHAI, K.; RUBEN, E.; NJITI, V.N.; LIGHTFOOT, D.A. Automated marker assisted selection for dual resistance: the soybean cyst nematode and Fusarium solani. In: INTERNATIONAL CONFERENCE OF PLANT \& ANIMAL GENOME, 7., San Diego, 1999. Proceedings. San Diego, 1999b. p.248. http://www.intlpag.org/pag/7/abstracts/ pag7225.html (13 Oct. 1999)

MELGAR, J.; ROY, K.W. Soybean sudden death syndrome: cultivar reactions to inoculation in a controlled environment and host range and virulence of causal agent. Plant Disease, v.78, p.265-268, 1994.

MELGAR, J.; ROY, K.W.; ABNEY, T.S. Sudden death syndrome of soybean: etiology, symptomatology, and effects of irrigation and Heterodera glycines on incidence and severity under field conditions. Canadian Journal of Botany, v.72, p.1647-1653, 1995.

MICHELMORE, R.W.; PARAN, I.; KESSELI, R.V. Identification of markers linked to diseaseresistance genes by bulked segregant analysis: a rapid method to detect markers in specific genomic regions by using segregating populations. Proceedings of the National Academic of Sciences of USA, v.88, p.9828-9832, 1991.

MOREIRA, R.M.P. Predição do comportamento de cruzamentos dialélicos de soja avaliados na geração $F_{3}$ em cultivo de inverno. Piracicaba, 1992. 95p. Dissertação (Mestrado) - Escola Superior de Agricultura “Luiz de Queiroz", Universidade de São Paulo.

MUDGE, J.; CREGAN, P.B.; KENWORTHY, J.P.; KENWORTHY, W.J.; ORF, J.H.; YOUNG, N.D. Two microsatellite markers that flank the major soybean cyst nematode resistance locus. Crop Science, v.37, p.1611-1615, 1997.

NASS, L.L. Potencialidade de genótipos de soja (Glycine max (L.) Merrill) para cultivo de inverno avaliada por cruzamentos dialélicos. Piracicaba, 1989. 112p. Dissertação (Mestrado) - Escola Superior de Agricultura "Luiz de Queiroz", Universidade de São Paulo.

NASSAR, R.F. Effect of correlated gene distribution due to sampling on the diallel analysis. Genetics, v.52, p.9-20, 1965.

NELDER, J.A. Statistical models in biometrical genetics. Heredity, v.7, p.111-119, 1953. 
NELSON, B.D.; HANSEN, J.M.; WINDELS, C.E.; HELMS, T.C. Reaction of soybean cultivars to isolates of Fusarium solani from the Red River Valley. Plant Disease, v.81, p.664-668, 1997.

NJITI, V.N.; DOUBLER, T.W.; SUTTNER, R.J.; GRAY, L.E.; GIBSON, P.T.; LIGHTFOOT, D.A. Resistance to soybean sudden death syndrome and root colonization by Fusarium solani f.sp. glycine in near-isogenic lines. Crop Science, v.38, p.472-477, 1998a.

NJITI, V.N.; JOHNSON, J.E.; TORTO, T.A.; GRAY, L.E.; LIGHTFOOT, D.A. Inoculum rate influences selection for field resistance to soybean sudden death syndrome in the greenhouse. Crop Science, v.41, p.1726-1731, 2001.

NJITI, V.N.; MEKSEM, K.; IQBAL, M.J.; JOHNSON, J.E.; KASSEM, M.A.; ZOBRIST, K.F.; KILO, V.Y.; LIGHTFOOT, D.A. Common loci underlie field resistance to soybean sudden death syndrome in Forrest, Pyramid, Essex, and Douglas. Theoretical and Applied Genetics, v.104, p.294-300, 2002.

NJITI, V.N.; SHENAUT, M.A.; SUTTNER, R.J.; SCHMIDT, M.E.; GIBSON, P.T. Soybean response to sudden death syndrome: inheritance influenced by cyst nematode resistance in Pyramid X Douglas progenies. Crop Science, v.36, p.1165-1170, 1996.

NJITI, V.N.; SHENAUT, M.A.; SUTTNER, R.J.; SCHMIDT, M.E.; GIBSON, P.T. Relationship between soybean sudden death syndrome disease measures and yield components in $\mathrm{F}_{6}$ derived lines. Crop Science, v.38, p.673-678, 1998b.

NJITI, V.N.; SUTTNER, R.J.; GRAY, L.E.; GIBSON, P.T.; LIGHTFOOT, D.A. Rate-reducing resistance to Fusarium solani f.sp. phaseoli underlies field resistance to soybean sudden death syndrome. Crop Science, v.37, p.132-138, $1997 \mathrm{a}$.

NJITI, V.N.; TORTO, G.A.; GRAY, L.E.; LIGHTFOOT, D.A. An effective greenhouse assay for field resistance to SDS. Soybean Genetics Newsletter, v.24, p.132-135, $1997 \mathrm{~b}$.

O'DONNEL, K.; GRAY, L.E. Phylogenetic relationships of the soybean sudden death syndrome pathogen Fusarium solani f.sp. phaseoli inferred from rDNA sequence data and PCR primers for its identification. Molecular Plant-Microbe Interactions, v.8, n.5, p.709-716, 1995. 
OLIVEIRA, V.R.; CASALI, V.W.D.; CRUZ, C.D.; SCAPIM, C.A.; PIRES, N.M. Genetic analysis of sweet pepper tolerance to low phosphorus availability in the soil. Crop Breeding and Applied Biotechnology, v.1, n.4, p.329-338, 2001.

PARK, H.G.; DAVIS, D.W. Inheritance of interlocular cavitation in a six-parent diallel cross in snap beans (Phaseolus vulgaris L.). Journal of American Society for Horticultural Science, v.101, n.2, p.184-189, 1976.

PRABHU, R.R.; DOUBLER, T.W.; CHANG, S.J.C.; LIGHTFOOT, D.A. Development and utility of sequence characterized amplified regions (SCARS) from RAPD markers linked to SDS and SCN QTLs. Soybean Genetics Newsletter, v.24, p.128-131, 1997.

PRABHU, R.R.; NJITI, V.N.; BELL-JOHNSON, B.; DHNSON, J.E.; SCHMIDT, M.E.; KLEIN, J.H.; LIGHTFOOT, D.A. Selecting soybean cultivars for dual resistance to soybean cyst nematode and sudden death syndrome using two DNA markers. Crop Science, v.39, p.982987, 1999.

RAMALHO, M.A.P.; SANTOS, J.B.; ZIMMERMANN, M.J.O. Genética quantitativa em plantas autógamas: aplicações ao melhoramento do feijoeiro. Goiânia: UFG, 1993. 271p.

RINGLER, G.A.; NICKELL, C.D. Genetic resistance to Fusarium solani in Pioneer Brand 9451 soybean. Soybean Genetics Newsletter, v.23, p.149-154, 1996.

RONGWEN, J.; AKKAYA, M.S.; BHAGWAT, A.A.; LAVI, U.; CREGAN, P.B. The use of microsatellite DNA markers for soybean genotype identification. Theoretical and Applied Genetics, v.90, p.43-48, 1995.

ROY, K.W. Fusarium solani on soybean roots: nomenclature of the causal agent of sudden death syndrome and identity and relevance of $F$. solani form B. Plant Disease, v.81, p.259266, 1997.

ROY, K.W.; LAWRENCE, G.W.; HODGES, H.H.; McLEAN, K.S.; KILLEBREW, J.F. Sudden death syndrome of soybean: Fusarium solani as incitant and relation of Heterodera glycines to disease severity. Phytopathology, v.79, p.191-197, 1989. 
ROY, K.W.; RUPE, J.C.; HERSCHMAN, D.E.; ABNEY, T.S. Sudden death syndrome of soybean. Plant Disease, v.81, p.1100-1111, 1997.

RUPE, J.C.; CORRELL, J.C.; GUERBER, J.C.; BECTON, C.M.; GBUR, E.E.; CUMMINGS, M.S.; YOUNT, P.A. Differentiation of the sudden death syndrome pathogen of soybean, Fusarium solani f.sp. glycines, from other isolates of $F$. solani based on cultural morphology, pathogenicity, and mitochondrial DNA restriction fragment length polymorphisms. Canadian Journal of Botany, v.79, p.829-835, 2001.

RUPE, J.C.; GBUR, E.E. Effect of plant age, maturity group, and the environment on disease progress of sudden death syndrome of soybean. Plant Disease, v.77, p.139-143, 1995.

RUPE, J.C.; GBUR, E.E.; MARX, D.M. Cultivar responses to sudden death syndrome of soybean. Plant Disease, v.75, p.47-50, 1991.

RUPE, J.C. Epidemiology of sudden death syndrome of soybean. In: CONGRESSO BRASILEIRO DE SOJA, Londrina, 1999. Anais. Londrina: Embrapa Soja, 1999. p.139-148.

SAGHAIMAROOF, M.A.; SOLIMAN, K.M.; JORGENSEN, R.A.; ALLARD, R.W. Ribosomal DNA spacer-length polymorphisms in barley: Mendelian inheritance, chromosomal location, and population dynamics. Proceedings of the National Academic of Sciences of USA, v.81, p.8014-8019, 1984.

SANTOS, J.B. Controle genético de caracteres agronômicos e potencialidades de cultivares de feijão (Phaseolus vulgaris L.) para o melhoramento genético. Piracicaba, 1984. 223p. Tese (Doutorado) - Escola Superior de Agricultura "Luiz de Queiroz", Universidade de São Paulo.

SAS INSTITUTE. SAS System: SAS/STAT version 8.0 (software). Cary, 1999.

SCANDIANI, M.M.; RUBERTI, D.S.; PIOLI, R; GIORDA, Y.L. Síndrome de la muerte repentina de la soja en el Norte de la provincia de Buenos Aires y Sur de Santa Fe. In: CONGRESSO BRASILEIRO DE SOJA, 2., Foz do Iguaçu, 2002. Resumos. Londrina: Embrapa Soja, 2002. p.76. 
SCHERM, H.; YANG, X.B. Development of sudden death syndrome of soybean in relation to soil temperature and soil water matric potential. Phytopathology, v.86, p.642-649, 1996.

SING, R.K.; CHAUDHARY, B.D. Biometrical methods in quantitative genetic analysis. 2.ed. New Delhi: Kalyani Publishers, 1979. cap.6, p.102-120: Diallel analysis.

SINGH, M.; SINGH, R.K. Some theoretical aspects of analysis in half diallel. Biometrical Journal, v.26, n.1, p.63-68, 1984a.

SINGH, M.; SINGH, R.K. Hayman's graphical analysis in segregating generations of a diallel cross. Biometrical Journal, v.26, n.1, p.69-74, 1984b.

SOKAL, R.R.; ROHLF, F.J Biometry: the principles and practice of statistics in biological research. 3.ed. New York: W.H. Freeman and Company, 1995. 887p.

SOKOL, M.J.; BAKER, R.J. Evaluation of the assumptions required for the genetic interpretation of diallel experiments in self-pollinating crops. Canadian Journal of Plant Science, v.57, p.1185-1191, 1977.

SPEHAR, C.R. Breeding soybeans to the low latitudes of Brazilian cerrados (savannahs).

Pesquisa Agropecuária Brasileira, v.29, n.8, p.1167-1180, 1994.

STEEL, R.G.D.; TORRIE, J.H. Principles and procedures of statistics: a biometrical aproach. 2.ed. New York: McGraw-Hill, 1980. 633p.

STEPHENS, P.A.; NICKELL, C.D.; KOLB, F.L. Genetic analysis of resistance to Fusarium solani in soybean. Crop Science, v.33, p.929-930, 1993a.

STEPHENS, P.A.; NICKELL, C.D.; LIM, S.M. Sudden death syndrome development in soybean cultivars differing in resistance to Fusarium solani. Crop Science, v.33, p.63-66, 1993b.

STEPHENS, P.A.; NICKELL, C.D.; MOOTS, C.K.; LIM, S.M. Relationship between field and greenhouse reactions of soybean to Fusarium solani. Plant Disease, v.77, p.163-166, 1993c. 
TANDON, J.P.; JOSHI, A.B.; JAIN, K.B.L. Comparison of graphic and combining ability analyses of diallel crosses in wheat. Indian Journal of Genetics \& Plant Breeding, v.30, n.1, p.91-103, 1970.

TOLEDO, J.F.F. Genética quantitativa das características de interesse do melhoramento da soja. In: EMPRESA BRASILEIRA DE PESQUISA AGROPECUÁRIA. Resultados de pesquisa de soja 1989/90. Londrina: EMBRAPA, CNPSo, 1993. p.260-263.

TOLEDO, J.F.F.; KIIHL, R.A.S. Métodos de análise dialélica do modelo genético em controle das características dias para floração e número de folhas trifolioladas em soja. Pesquisa Agropecuária Brasileira, v.17, n.5, p.745-755, 1982.

TORTO, G.A.; NJITI, V.; LIGHTFOOT, D.A. Loci underlying resistance to sudden death syndrome and Fusarium solani in field and greenhouse assays do not correspond. Soybean Genetics Newsletter, v.23, p.163-166, 1996.

TRIWITAYAKORN, K.T.; JAMAI, A.; SCHULZ, J.; IQBAL, J.; MEKSEM, K., TOWN, C.; LIGHTFOOT, D.A. Genomic approaches to molecular breeding of resistance to soybean sudden death syndrome and cyst nematode in elite cultivars. In: CONGRESSO BRASILEIRO DE SOJA, 2., Foz do Iguaçu, 2002. Anais. Londrina: Embrapa Soja, 2002. p.70-71.

VELLO, N.A. Métodos de melhoramento da soja. In: CÂMARA, G.M.S.; MARCOS FILHO, J.; OLIVEIRA, E.A.M. (Ed.). In: SIMPÓSIO SOBRE A CULTURA E PRODUTIVIDADE DA SOJA, 1., Piracicaba, 1991. Anais. Piracicaba: FEALQ, 1992. p.41-59.

VENCOVSKY, R.; BARRIGA, P. Genética biométrica no fitomelhoramento. Ribeirão Preto: Sociedade Brasileira de Genética, 1992. 496p.

VERHALEN, L.M.; MURRAY, J.C. A diallel analysis of several fiber property traits in upland cotton (Gossypium hirsutum L.). Crop Science, v.9, p.311-315, 1969.

WRATHER, J.A.; ANDERSON, T.R.; ARSYAD, D.M.; GAI, J.; PLOPER, L.D.; PORTA-PUGLIA, A.; RAM, H.H.; YORINORI, J.T. Soybean disease loss estimates for the top 10 soybean producing countries in 1994. Plant Disease, v.81, p.107-110, 1997. 
XU, Y.B.; SHEN, Z.T. Diallel analysis of tiller number at different growth stages in rice (Oryza sativa L.). Theorethical and Applied Genetics, v.83, p.243-249, 1991.

YANG, X.B.; RIZVI, S.S. Fisrt report of sudden death syndrome of soybean in lowa. Plant Disease, v.78, p.830, 1994.

YORINORI, J.T. Podridão vermelha da raiz, uma séria doença da soja e do feijão, causada por Fusarium solani. Fitopatologia Brasileira, v.19, p.333, 1994. /Resumo/

YORINORI, J.T. Distribuição geográfica e níveis de danos da podridão vermelha da raiz em soja. In: REUNIÃO DE PESQUISA DE SOJA DA REGIÃO CENTRAL DO BRASIL, 18., Uberlândia, 1996. Ata e resumos. Uberlândia: UFU, DEAGO, 1997. p.320-321.

YORINORI, J.T. Situação atual das doenças potenciais no Cone Sul. In: CONGRESSO BRASILEIRO DE SOJA, 2., Foz do Iguaçu, 2002. Anais. Londrina: Embrapa Soja, 2002. p.171-186.

YORINORI, J.T.; CHARCHAR, M.J.D'A.; NASSER, L.C.B.; HENNING, A.A. Doenças da soja e seu controle. In: ARANTES, N.E.; SOUZA, P.I.M. (Ed.). Cultura da soja nos cerrados. Piracicaba: POTAFOS, 1993. p.333-397.

YORINORI, J.T.; HIROMOTO, D.M. Controle integrado de doenças de soja: determinação de perdas de vigor em soja causadas por doenças fúngicas. In: EMPRESA BRASILEIRA DE PESQUISA AGROPECUÁRIA. Resultados de pesquisa da Embrapa Soja 1997. Londrina: EMBRAPA, CNPSo, 1998. p.112-114.

YORINORI, J.T.; NOMURA, S.L. Cultivares de soja resistentes à podridão vermelha da raiz causada por Fusarium solani. Fitopatologia Brasileira, v.19, p.339, 1994. Suplemento. /Resumo/

ZENG, Z.-B. Precision mapping of quantitative trait loci. Genetics, v.136, p.1457-1468, 1994. 


\section{APÊNDICES}


APÊNDICE 1 - Resumo da análise de resíduos e resultado do teste de Bartlett $\left(\mathrm{X}^{2}\right)$ para as variáveis analisadas (média de vasos com cinco plantas) em três experimentos conduzidos com a geração $F_{2}$ do dialelo $5 \times 5$. Soja, Piracicaba-SP.

\begin{tabular}{|c|c|c|c|c|c|c|c|c|c|}
\hline Experimentos & Variável $^{1}$ & "Skewness" & Kurtose & $\mathrm{W}$ & $P<W$ & Var $_{\text {mín. }}$ & Var $_{\text {máx. }}$ & $F_{\text {máx. }}$ & $x^{2}$ \\
\hline \multirow{5}{*}{ TE-JUL01 } & SR & 0,20 & $-0,21$ & 0,993 & 0,103 & 0,21 & 0,58 & 2,72 & - \\
\hline & $\mathrm{CLR}^{2}$ & $-0,07$ & 0,28 & 0,994 & 0,191 & 0,33 & 0,88 & 2,68 & - \\
\hline & $S F^{2}$ & 0,34 & 0,27 & 0,991 & $0,029^{*}$ & 0,013 & 0,053 & 4,14 & - \\
\hline & $\mathrm{IF}^{3}$ & $-0,18$ & 0,01 & 0,977 & $<0,0001^{\star *}$ & 0,08 & 0,26 & 3,38 & - \\
\hline & IDF & 0,27 & 0,06 & 0,994 & 0,147 & 131,06 & 433,42 & 3,31 & - \\
\hline \multirow{3}{*}{ CV-SET01 } & $\mathrm{SF}^{2}$ & 0,19 & $-0,22$ & 0,994 & 0,200 & 0,008 & 0,036 & 4,30 & - \\
\hline & $\mathrm{IF}^{3}$ & $-1,04$ & 1,55 & 0,927 & $<0,0001^{\star *}$ & 0,02 & 0,16 & $7,46^{\star \star}$ & - \\
\hline & IDF & $-0,19$ & $-0,07$ & 0,996 & 0,485 & 40,64 & 231,03 & 5,68 & - \\
\hline \multirow{6}{*}{ CV-JUL02 } & SF & $-0,11$ & $-0,36$ & 0,996 & 0,436 & 0,38 & 1,67 & 4,37 & 16,25 \\
\hline & $\mathrm{IF}^{3}$ & $-0,47$ & 0,22 & 0,977 & $<0,0001^{* *}$ & 0,00 & 0,29 & - & $660,61^{* *}$ \\
\hline & IDF & $-0,01$ & $-0,53$ & 0,993 & 0,094 & 273,28 & 1190,87 & 4,36 & 19,43 \\
\hline & SP & $-0,01$ & $-0,35$ & 0,996 & 0,596 & 0,35 & 1,65 & 4,66 & 23,10 \\
\hline & IDP & 0,03 & $-0,52$ & 0,994 & 0,185 & 147,73 & 1154,07 & $7,81^{* *}$ & $25,83^{*}$ \\
\hline & SP1 & $-0,17$ & $-0,21$ & 0,993 & 0,133 & 0,21 & 1,09 & 5,09 & $24,36^{*}$ \\
\hline
\end{tabular}

${ }^{1}$ SR e CLR: severidade (1 a 5) e comprimento da lesão nas raízes (mm); SF e IDF: severidade (1 a 5) e índice de doença com base na nota do folíolo; SP e IDP: severidade (1 a 5) e índice de doença com base na nota da planta; IF: incidência da doença (\%); SP1: severidade dos sintomas foliares desconsiderando plantas com nota igual a 1 .

${ }^{2}$ Dados transformados para $\sqrt{\mathrm{x}+0,5}$.

${ }^{3}$ Dados transformados para arco seno $\sqrt{\mathrm{x} / 100}$. 
APÊNDICE 2 - Temperaturas do ar e do solo durante o período de condução do experimento com a geração $F_{2}$ do dialelo $5 \times 5$, conduzido em telado (TE-JUL01). Soja, Piracicaba-SP.

\begin{tabular}{|c|c|c|c|c|c|c|c|c|}
\hline \multirow[b]{2}{*}{ Data } & \multicolumn{3}{|c|}{ Temperatura do $\mathrm{Ar}$} & \multicolumn{5}{|c|}{ Temperatura do Solo $(5 \mathrm{~cm})$} \\
\hline & Máxima & Mínima & 16 Horas & Bloco 1 & Bloco 2 & Bloco 3 & Bloco 4 & Bloco 5 \\
\hline $11 / 07$ & 28,0 & 12,0 & 28,0 & 21,5 & 21,0 & 19,0 & 18,0 & 18,0 \\
\hline $12 / 07$ & 18,0 & 16,0 & 17,0 & 15,0 & 16,0 & 16,0 & 15,0 & 15,0 \\
\hline $13 / 07$ & 24,0 & 12,0 & 22,5 & 19,0 & 20,5 & 20,0 & 16,0 & 16,0 \\
\hline $14 / 07$ & 27,0 & 8,0 & 21,5 & 18,0 & 16,0 & 15,5 & 15,0 & 15,0 \\
\hline $15 / 07$ & 28,0 & 12,0 & 26,0 & 24,0 & 23,0 & 20,0 & 18,5 & 19,0 \\
\hline $16 / 07$ & 31,0 & 14,0 & 29,0 & 25,0 & 24,0 & 21,0 & 19,5 & 20,0 \\
\hline $17 / 07$ & 30,0 & 12,5 & 28,0 & 24,5 & 23,5 & 20,0 & 18,0 & 18,0 \\
\hline $18 / 07$ & 31,0 & 12,5 & 29,5 & 24,0 & 24,5 & 21,0 & 19,0 & 19,5 \\
\hline $19 / 07$ & 27,5 & 16,0 & 25,0 & 19,0 & 19,5 & 18,5 & 18,0 & 18,5 \\
\hline $20 / 07$ & 31,0 & 16,0 & 29,0 & 22,0 & 22,5 & 20,0 & 19,0 & 20,0 \\
\hline 20 Decêndio & 27,6 & 13,1 & 25,6 & 21,2 & 21,1 & 19,1 & 17,6 & 17,9 \\
\hline $21 / 07$ & 31,0 & 16,0 & 30,0 & 23,5 & 23,5 & 22,0 & 21,0 & 21,5 \\
\hline $22 / 07$ & 22,0 & 17,0 & 21,0 & 18,5 & 19,0 & 19,0 & 17,5 & 18,0 \\
\hline $23 / 07$ & 21,0 & 16,5 & 21,0 & 17,5 & 18,0 & 17,0 & 15,5 & 16,0 \\
\hline $24 / 07$ & 26,5 & 12,0 & 26,5 & 23,0 & 22,5 & 21,0 & 19,0 & 19,0 \\
\hline $25 / 07$ & 27,0 & 16,0 & 22,5 & 19,0 & 19,0 & 19,0 & 18,0 & 18,5 \\
\hline $26 / 07$ & 23,5 & 18,0 & 23,0 & 20,0 & 20,0 & 19,5 & 18,5 & 19,0 \\
\hline $27 / 07$ & 26,5 & 17,5 & 24,5 & 21,0 & 21,0 & 20,5 & 20,0 & 20,0 \\
\hline $28 / 07$ & 14,0 & 12,0 & 13,0 & 10,5 & 10,5 & 11,0 & 9,5 & 10,0 \\
\hline $29 / 07$ & 25,5 & 5,5 & 25,5 & 19,5 & 20,5 & 19,5 & 15,0 & 15,0 \\
\hline $30 / 07$ & 31,0 & 12,0 & 28,5 & 26,0 & 25,0 & 21,0 & 19,0 & 19,0 \\
\hline $31 / 07$ & 30,5 & 12,5 & 28,5 & 24,5 & 23,0 & 21,0 & 19,5 & 19,5 \\
\hline 3ํDecêndio & 25,3 & 14,1 & 24,0 & 20,3 & 20,2 & 19,1 & 17,5 & 17,8 \\
\hline $01 / 08$ & 31,0 & 12,5 & 29,0 & 26,0 & 26,0 & 21,0 & 19,5 & 19,5 \\
\hline $02 / 08$ & 31,0 & 12,0 & 29,0 & 26,0 & 24,0 & 20,5 & 18,0 & 18,0 \\
\hline 03/08 & 31,0 & 12,0 & 30,0 & 25,0 & 25,5 & 23,0 & 19,0 & 19,0 \\
\hline $04 / 08$ & 31,0 & 12,0 & 30,0 & 27,0 & 25,0 & 22,0 & 20,0 & 20,0 \\
\hline $05 / 08$ & 31,0 & 12,0 & - & - & - & - & - & - \\
\hline $06 / 08$ & 31,5 & 12,0 & 29,0 & 26,5 & 24,5 & 21,0 & 19,0 & 19,0 \\
\hline $07 / 08$ & 31,0 & 12,0 & 29,5 & 24,5 & 22,0 & 20,5 & 18,5 & 19,0 \\
\hline 08/08 & 27,0 & 12,0 & 26,0 & 22,0 & 23,0 & 21,0 & 18,0 & 19,0 \\
\hline 09/08 & 27,0 & 12,0 & 27,0 & 24,5 & 24,0 & 22,0 & 18,0 & 18,0 \\
\hline $10 / 08$ & 27,0 & 12,0 & 27,0 & 24,0 & 22,0 & 21,0 & 18,0 & 18,0 \\
\hline 10 Decêndio & 29.9 & 12.1 & 28.5 & 25,1 & 24.0 & 21,3 & 18.7 & 18.8 \\
\hline $11 / 08$ & 27,0 & 12,0 & 27,5 & 26,0 & 23,5 & 20,5 & 18,0 & 18,0 \\
\hline $12 / 08$ & 27,5 & 16,5 & 28,0 & 26,0 & 23,0 & 20,0 & 19,0 & 19,0 \\
\hline $13 / 08$ & 28,0 & 12,5 & 27,5 & 25,0 & 22,5 & 20,0 & 17,5 & 18,0 \\
\hline $14 / 08$ & 27,0 & 12,0 & 26,5 & 23,0 & 21,0 & 19,0 & 17,5 & 17,0 \\
\hline $15 / 08$ & 27,5 & 12,0 & 27,0 & 25,5 & 23,0 & 19,5 & 18,0 & 18,0 \\
\hline $16 / 08$ & 27,5 & 12,0 & 27,0 & 25,0 & 23,5 & 20,0 & 18,5 & 18,5 \\
\hline $17 / 08$ & 27,0 & 12,0 & 27,0 & 24,0 & 22,0 & 19,0 & 18,0 & 18,0 \\
\hline $18 / 08$ & 28,0 & 12,0 & 28,0 & 24,5 & 22,0 & 20,0 & 19,0 & 19,0 \\
\hline $19 / 08$ & 30,0 & 13,0 & 30,5 & 26,5 & 24,5 & 21,5 & 21,0 & 21,0 \\
\hline $20 / 08$ & 30,5 & 16,0 & 28,5 & 23,0 & 22,0 & 20,5 & 20,0 & 20,0 \\
\hline 20 Decêndio & 28,0 & 13,0 & 27,8 & 24,9 & 22,7 & 20,0 & 18,7 & 18,7 \\
\hline $21 / 08$ & 29,0 & 14,5 & 29,0 & 24,0 & 23,0 & 21,0 & 20,0 & 20,0 \\
\hline $22 / 08$ & 26,5 & 16,0 & 24,5 & 22,5 & 22,0 & 20,5 & 19,0 & 19,0 \\
\hline $23 / 08$ & 21,0 & 14,5 & 18,5 & 16,0 & 16,0 & 15,5 & 15,0 & 15,5 \\
\hline $24 / 08$ & 23,0 & 16,0 & 19,0 & 18,0 & 18,0 & 18,0 & 17,0 & 17,5 \\
\hline $25 / 08$ & 30,0 & 16,0 & 30,0 & 25,0 & 23,5 & 22,5 & 21,5 & 21,0 \\
\hline $26 / 08$ & 28,5 & 17,0 & 27,5 & 22,5 & 22,0 & 21,0 & 20,0 & 20,0 \\
\hline $27 / 08$ & 28,0 & 18,5 & 28,0 & 23,0 & 22,5 & 21,5 & 21,0 & 21,0 \\
\hline $28 / 08$ & 28,0 & 17,5 & 29,0 & 24,5 & 23,5 & 22,0 & 21,0 & 21,5 \\
\hline $29 / 08$ & 29,0 & 18,5 & 25,0 & 22,0 & 22,0 & 21,0 & 20,0 & 20,5 \\
\hline $30 / 08$ & 30,5 & 16,0 & 30,0 & 25,5 & 26,0 & 24,5 & 22,0 & 22,5 \\
\hline $31 / 08$ & - & 17,0 & 32,0 & 27,5 & 25,5 & 25,0 & 24,0 & 23,0 \\
\hline 3믈ecêndio & 27,4 & 16,5 & 26,6 & 22,8 & 22,2 & 21,1 & 20,0 & 20,1 \\
\hline
\end{tabular}


APÊNDICE 3 - Temperaturas do ar e do solo durante o período de condução do experimento com a geração $F_{2}$ do dialelo $5 \times 5$, conduzido em casa de vegetação (CVSET01). Soja, Piracicaba-SP.

\begin{tabular}{|c|c|c|c|c|c|c|c|c|}
\hline \multirow[b]{2}{*}{ Data } & \multicolumn{3}{|c|}{ Temperatura do $\mathrm{Ar}$} & \multicolumn{5}{|c|}{ Temperatura do Solo $(5 \mathrm{~cm})$} \\
\hline & Máxima & Mínima & 16 Horas & Bloco 1 & Bloco 2 & Bloco 3 & Bloco 4 & Bloco 5 \\
\hline $26 / 09$ & 30,5 & - & - & - & - & - & - & - \\
\hline $27 / 09$ & 28,0 & 20,5 & 28,0 & 23,0 & 23,0 & 23,0 & 23,0 & - \\
\hline $28 / 09$ & 30,0 & 18,5 & 28,5 & 25,0 & 26,0 & 25,0 & 25,0 & 24,0 \\
\hline $29 / 09$ & 30,0 & 20,5 & 30,0 & 24,5 & 27,0 & 24,0 & 24,0 & 23,0 \\
\hline $30 / 09$ & 31,5 & 20,5 & 31,0 & 25,0 & 28,0 & 25,0 & 24,5 & 23,0 \\
\hline 6 Qüinqüídio & 30,0 & 20,0 & 29,4 & 24,4 & 26,0 & 24,3 & 24,1 & 23,3 \\
\hline $01 / 10$ & 28,0 & 21,0 & 28,0 & 23,0 & 25,0 & 23,5 & 23,0 & 22,0 \\
\hline $02 / 10$ & 27,5 & 20,5 & 23,0 & 22,0 & 22,0 & 22,0 & 21,5 & 21,5 \\
\hline 03/10 & 29,0 & 16,0 & 28,0 & 23,0 & 25,5 & 24,0 & 22,5 & 22,0 \\
\hline $04 / 10$ & 30,0 & 16,0 & 27,0 & 23,0 & 24,0 & 23,0 & 23,0 & 21,5 \\
\hline $05 / 10$ & 29,5 & 17,0 & 26,0 & 23,0 & 24,5 & 23,0 & 23,0 & 21,5 \\
\hline $06 / 10$ & 30,0 & 17,0 & 29,5 & 24,0 & 25,0 & 24,0 & 23,0 & 22,0 \\
\hline $07 / 10$ & 29,5 & 18,0 & 29,0 & 24,0 & 24,5 & 24,0 & 24,0 & 23,0 \\
\hline $08 / 10$ & 24,5 & 20,5 & 23,0 & 21,5 & 22,5 & 21,5 & 21,5 & 21,5 \\
\hline $09 / 10$ & 27,0 & 20,0 & 27,0 & 24,0 & 25,0 & 24,0 & 24,0 & 23,0 \\
\hline $10 / 10$ & 31,0 & 20,5 & 30,5 & 25,0 & 26,0 & 24,5 & 24,0 & 24,0 \\
\hline 10 Decêndio & 29,0 & 18,7 & 27,1 & 23,3 & 24,4 & 23,4 & 23,0 & 22,2 \\
\hline $11 / 10$ & 30,0 & 20,5 & 28,0 & 24,5 & 25,5 & 25,0 & 24,5 & 23,5 \\
\hline $12 / 10$ & 31,0 & 20,5 & 30,5 & 24,0 & 25,5 & 24,0 & 24,0 & 23,0 \\
\hline $13 / 10$ & 29,5 & 20,5 & 29,0 & 23,0 & 24,5 & 23,0 & 23,0 & 22,0 \\
\hline $14 / 10$ & 27,0 & 17,5 & 26,5 & 23,0 & 24,0 & 23,0 & 23,0 & 22,5 \\
\hline $15 / 10$ & 28,5 & 16,5 & 28,5 & 23,0 & 24,0 & 23,0 & 23,0 & 22,5 \\
\hline $16 / 10$ & 29,5 & 16,5 & 29,5 & 23,5 & 24,5 & 23,5 & 23,0 & 22,0 \\
\hline $17 / 10$ & 27,5 & 17,0 & 26,0 & 23,0 & 24,0 & 23,0 & 23,0 & 22,5 \\
\hline $18 / 10$ & 30,0 & 20,5 & 30,0 & 24,0 & 25,0 & 23,5 & 24,0 & 23,0 \\
\hline $19 / 10$ & 29,5 & 20,5 & 29,0 & 23,5 & 25,0 & 23,5 & 23,0 & 23,0 \\
\hline $20 / 10$ & 31,0 & 20,5 & 29,0 & 23,5 & 24,5 & 23,5 & 23,5 & 23,0 \\
\hline $2^{\circ}$ Decêndio & 29,4 & 19,1 & 28,6 & 23,5 & 24,7 & 23,5 & 23,4 & 22,7 \\
\hline $21 / 10$ & 29,0 & 19,0 & 25,5 & 23,5 & 24,5 & 23,0 & 23,0 & 23,0 \\
\hline $22 / 10$ & 31,0 & 20,5 & 29,5 & 23,5 & 24,5 & 24,0 & 23,5 & 23,0 \\
\hline $23 / 10$ & 31,5 & 20,5 & 25,0 & 23,0 & 23,0 & 22,0 & 22,0 & 21,0 \\
\hline $24 / 10$ & 28,0 & 16,0 & 27,5 & 21,0 & 23,0 & 21,0 & 21,0 & 21,0 \\
\hline $25 / 10$ & 31,0 & 16,5 & 29,0 & 22,0 & 23,5 & 22,0 & 22,0 & 21,5 \\
\hline $26 / 10$ & 29,5 & 16,0 & 28,5 & 22,0 & 23,5 & 22,0 & 21,0 & 21,0 \\
\hline $27 / 10$ & 28,0 & 16,5 & 25,0 & 21,0 & 22,0 & 21,0 & 21,0 & 20,0 \\
\hline $28 / 10$ & 29,0 & 17,0 & 29,0 & 22,0 & 23,5 & 22,5 & 22,0 & 21,0 \\
\hline $29 / 10$ & 27,5 & 18,5 & - & - & - & - & - & - \\
\hline $30 / 10$ & - & 20,0 & 29,5 & 22,0 & 23,5 & 22,5 & 22,0 & 21,0 \\
\hline 3ํDecêndio & 29,4 & 18,1 & 27,6 & 22,2 & 23,4 & 22,2 & 21,9 & 21,4 \\
\hline
\end{tabular}


APÊNDICE 4 - Temperaturas do ar e do solo durante o período de condução do experimento com a geração $F_{2}$ do dialelo $5 \times 5$, conduzido em casa de vegetação (CV-JUL02). Soja, Piracicaba-SP.

\begin{tabular}{|c|c|c|c|c|}
\hline \multirow[b]{2}{*}{ Data } & \multicolumn{2}{|c|}{ Temperatura do $\mathrm{Ar}$} & \multicolumn{2}{|c|}{ Temperatura do Solo $(4 \mathrm{~cm})$} \\
\hline & Máxima & Mínima & Máxima & Mínima \\
\hline $01 / 08$ & 23,0 & 18,5 & 22,5 & 17,6 \\
\hline $02 / 08$ & 22,5 & 18,0 & 21,2 & 17,0 \\
\hline $03 / 08$ & 24,0 & 18,5 & 21,3 & 17,5 \\
\hline $04 / 08$ & 28,0 & 15,0 & 25,7 & 14,5 \\
\hline 05/08 & 28,0 & 17,0 & 23,9 & 16,4 \\
\hline 06/08 & 28,0 & 17,5 & 25,2 & 16,9 \\
\hline $07 / 08$ & 29,5 & 17,5 & 26,0 & 17,2 \\
\hline 08/08 & 29,0 & 17,5 & 25,7 & 17,2 \\
\hline 09/08 & 28,0 & 20,0 & 24,6 & 18,2 \\
\hline $10 / 08$ & 27,0 & 17,0 & 24,3 & 16,4 \\
\hline $1^{\circ}$ Decêndio & 26,7 & 17,7 & 24,0 & 16,9 \\
\hline $11 / 08$ & 27,5 & 16,0 & 24,6 & 14,5 \\
\hline $12 / 08$ & 27,5 & 16,5 & 24,2 & 15,6 \\
\hline $13 / 08$ & 27,5 & 16,0 & 24,2 & 15,6 \\
\hline $14 / 08$ & 27,0 & 16,0 & 24,4 & 15,6 \\
\hline $15 / 08$ & 27,5 & 16,0 & 24,5 & 15,6 \\
\hline $16 / 08$ & 27,0 & 17,0 & 24,3 & 15,6 \\
\hline $17 / 08$ & 27,0 & 16,5 & 23,9 & 16,1 \\
\hline $18 / 08$ & 27,5 & 16,5 & 23,7 & 15,5 \\
\hline $19 / 08$ & 26,0 & 16,5 & 24,3 & 15,8 \\
\hline $20 / 08$ & 26,0 & 16,5 & 26,2 & 15,7 \\
\hline $2^{\circ}$ Decêndio & 27,1 & 16,4 & 24,4 & 15,6 \\
\hline $21 / 08$ & 33,5 & 16,0 & 28,0 & 14,6 \\
\hline $22 / 08$ & 28,5 & 17,5 & 23,0 & 17,3 \\
\hline $23 / 08$ & 28,0 & 17,0 & 24,9 & 16,6 \\
\hline $24 / 08$ & 29,0 & 17,0 & 25,1 & 16,6 \\
\hline $25 / 08$ & 27,0 & 16,5 & 25,1 & 15,5 \\
\hline $26 / 08$ & 29,0 & 14,5 & 24,6 & 14,0 \\
\hline $27 / 08$ & 30,0 & 14,0 & 24,3 & 13,4 \\
\hline $28 / 08$ & 29,5 & 15,0 & 24,3 & 14,4 \\
\hline $29 / 08$ & 26,0 & 16,0 & 21,3 & 14,6 \\
\hline $30 / 08$ & 29,0 & 17,0 & 23,2 & 16,7 \\
\hline $31 / 08$ & 27,5 & 16,5 & 22,8 & 15,9 \\
\hline 3ํDecêndio & 28,8 & 16,1 & 24,2 & 15,4 \\
\hline $01 / 09$ & 27,0 & 16,0 & 23,4 & 14,9 \\
\hline $02 / 09$ & 27,5 & 9,0 & 22,9 & 9,4 \\
\hline 03/09 & 28,0 & 6,5 & 22,5 & 6,8 \\
\hline $04 / 09$ & 28,0 & 11,0 & 22,6 & 10,7 \\
\hline 05/09 & 29,0 & 14,0 & 22,0 & 13,7 \\
\hline 06/09 & 30,0 & 17,5 & 25,7 & 16,6 \\
\hline 07/09 & 28,5 & 19,5 & 23,4 & 18,2 \\
\hline 08/09 & 28,0 & 17,0 & 23,1 & 15,7 \\
\hline 09/09 & 28,0 & 16,5 & 22,3 & 14,3 \\
\hline $10 / 09$ & 28,0 & 16,5 & 24,1 & 15,1 \\
\hline 10 Decêndio & 28,2 & 14,4 & 23,2 & 13,5 \\
\hline
\end{tabular}


APÊNDICE 5 - Distribuição de frequências fenotípicas de severidade da PVR com base na nota do folíolo com os sintomas mais intensos, média de sintomas foliares (SF) e variância das plantas de soja da geração $F_{2}$ do dialelo $5 \times 5$, no experimento conduzido em telado (TE-JUL01). Soja, Piracicaba-SP.

\begin{tabular}{|c|c|c|c|c|c|c|c|c|c|c|c|c|}
\hline \multirow[b]{2}{*}{ Tratamentos } & \multicolumn{9}{|c|}{ Classes Fenotípicas de Severidade (1 a 5) } & \multirow[b]{2}{*}{ Total } & \multirow[b]{2}{*}{ SF } & \multirow{2}{*}{$\begin{array}{c}\text { Variân- } \\
\text { cia }\end{array}$} \\
\hline & 1 & 1,5 & 2 & 2,5 & 3 & 3,5 & 4 & 4,5 & 5 & & & \\
\hline Conquista & 10 & 15 & 10 & 7 & 4 & 4 & 0 & 0 & 0 & 50 & 1,92 & 0,58 \\
\hline Cristalina & 6 & 12 & 13 & 9 & 3 & 1 & 0 & 6 & 0 & 50 & 2,24 & 1,04 \\
\hline Estrela & 12 & 17 & 5 & 2 & 1 & 0 & 3 & 9 & 0 & 49 & 2,20 & 1,75 \\
\hline Forrest & 18 & 12 & 9 & 5 & 2 & 1 & 1 & 0 & 0 & 48 & 1,67 & 0,54 \\
\hline IAC-4 & 12 & 6 & 9 & 6 & 3 & 3 & 4 & 7 & 0 & 50 & 2,42 & 1,54 \\
\hline Conquista $\times$ Cristalina & 33 & 25 & 25 & 25 & 16 & 10 & 5 & 11 & 0 & 150 & 2,24 & 1,10 \\
\hline Conquista $\times$ Estrela & 38 & 39 & 18 & 13 & 10 & 5 & 8 & 14 & 2 & 147 & 2,16 & 1,41 \\
\hline Conquista $\times$ Forrest & 44 & 40 & 24 & 22 & 7 & 7 & 2 & 3 & 0 & 149 & 1,84 & 0,71 \\
\hline Conquista x IAC-4 & 39 & 37 & 22 & 17 & 8 & 9 & 7 & 9 & 1 & 149 & 2,08 & 1,17 \\
\hline Cristalina $\times$ Estrela & 26 & 47 & 17 & 20 & 12 & 3 & 6 & 17 & 1 & 149 & 2,23 & 1,30 \\
\hline Cristalina $x$ Forrest & 24 & 41 & 30 & 19 & 17 & 9 & 3 & 6 & 0 & 149 & 2,11 & 0,84 \\
\hline Cristalina x IAC-4 & 25 & 38 & 25 & 8 & 9 & 11 & 10 & 19 & 1 & 146 & 2,38 & 1,49 \\
\hline Estrela x Forrest & 33 & 38 & 31 & 20 & 9 & 6 & 6 & 5 & 0 & 148 & 2,00 & 0,85 \\
\hline Estrela x IAC-4 & 32 & 43 & 20 & 15 & 9 & 7 & 4 & 19 & 0 & 149 & 2,19 & 1,35 \\
\hline Forrest x IAC-4 & 29 & 39 & 33 & 14 & 6 & 7 & 4 & 12 & 1 & 145 & 2,11 & 1,13 \\
\hline Total de Plantas & 381 & 449 & 291 & 202 & 116 & 83 & 63 & 137 & 6 & 1728 & 2,12 & 1,12 \\
\hline
\end{tabular}


APÊNDICE 6 - Distribuição de frequências fenotípicas de severidade da PVR com base na nota do folíolo com os sintomas mais intensos, média de sintomas foliares (SF) e variância das plantas de soja na geração $F_{2}$ do dialelo $5 \times 5$, no experimento conduzido em casa de vegetação (CV-SET01). Soja, Piracicaba-SP.

\begin{tabular}{|c|c|c|c|c|c|c|c|c|c|c|c|c|}
\hline \multirow[b]{2}{*}{ Tratamentos } & \multicolumn{9}{|c|}{ Classes Fenotípicas de Severidade (1 a 5) } & \multirow[b]{2}{*}{ Total } & \multirow[b]{2}{*}{ SF } & \multirow{2}{*}{$\begin{array}{c}\text { Variân- } \\
\text { cia }\end{array}$} \\
\hline & 1 & 1,5 & 2 & 2,5 & 3 & 3,5 & 4 & 4,5 & 5 & & & \\
\hline Conquista & 8 & 29 & 7 & 2 & 0 & 1 & 2 & 1 & 0 & 50 & 1,73 & 0,58 \\
\hline Cristalina & 1 & 28 & 9 & 2 & 1 & 0 & 5 & 3 & 1 & 50 & 2,15 & 1,15 \\
\hline Estrela & 1 & 20 & 13 & 3 & 2 & 0 & 6 & 4 & 0 & 49 & 2,30 & 1,11 \\
\hline Forrest & 4 & 19 & 15 & 6 & 4 & 0 & 1 & 0 & 0 & 49 & 1,91 & 0,37 \\
\hline IAC-4 & 1 & 41 & 3 & 0 & 3 & 0 & 2 & 0 & 0 & 50 & 1,71 & 0,37 \\
\hline Conquista $\times$ Cristalina & 16 & 93 & 24 & 4 & 4 & 2 & 5 & 2 & 0 & 150 & 1,74 & 0,48 \\
\hline Conquista $\times$ Estrela & 11 & 74 & 31 & 2 & 4 & 5 & 16 & 7 & 0 & 150 & 2,09 & 1,02 \\
\hline Conquista $\times$ Forrest & 17 & 71 & 37 & 7 & 5 & 10 & 2 & 1 & 0 & 150 & 1,85 & 0,50 \\
\hline Conquista $\times$ IAC-4 & 22 & 71 & 31 & 7 & 4 & 3 & 8 & 4 & 0 & 150 & 1,87 & 0,72 \\
\hline Cristalina $x$ Estrela & 6 & 78 & 28 & 2 & 5 & 5 & 18 & 7 & 1 & 150 & 2,17 & 1,09 \\
\hline Cristalina $x$ Forrest & 6 & 75 & 36 & 11 & 3 & 7 & 9 & 3 & 0 & 150 & 2,01 & 0,68 \\
\hline Cristalina x IAC-4 & 14 & 83 & 17 & 7 & 8 & 6 & 10 & 4 & 1 & 150 & 1,99 & 0,89 \\
\hline Estrela $\times$ Forrest & 24 & 63 & 31 & 3 & 7 & 5 & 10 & 7 & 0 & 150 & 1,99 & 0,96 \\
\hline Estrela x IAC-4 & 15 & 79 & 18 & 8 & 3 & 5 & 10 & 11 & 1 & 150 & 2,07 & 1,13 \\
\hline Forrest $x$ IAC-4 & 19 & 75 & 22 & 4 & 8 & 6 & 12 & 2 & 2 & 150 & 1,98 & 0,93 \\
\hline Total de Plantas & 165 & 899 & 322 & 68 & 61 & 55 & 116 & 56 & 6 & 1748 & 1,97 & 0,80 \\
\hline
\end{tabular}


APÊNDICE 7 - Distribuição de frequências fenotípicas ce severidade da PVR com base na nota de aspecto geral da planta, média de sintomas foliares (SP) e variância das plantas de soja da geração $F_{2}$ do dialelo $5 \times 5$, no experimento conduzido em casa de vegetação (CV-JUL02). Soja, Piracicaba-SP.

\begin{tabular}{|c|c|c|c|c|c|c|c|c|c|c|c|c|}
\hline \multirow[b]{2}{*}{ Tratamentos } & \multicolumn{9}{|c|}{ Classes Fenotípicas de Severidade (1 a 5) } & \multirow[b]{2}{*}{ Total } & \multirow[b]{2}{*}{ SP } & \multirow{2}{*}{$\begin{array}{c}\text { Variân- } \\
\text { cia }\end{array}$} \\
\hline & 1 & 1,5 & 2 & 2,5 & 3 & 3,5 & 4 & 4,5 & 5 & & & \\
\hline Conquista & 8 & 10 & 5 & 4 & 2 & 11 & 6 & 0 & 1 & 47 & 2,48 & 1,31 \\
\hline Cristalina & 11 & 2 & 0 & 8 & 3 & 5 & 4 & 2 & 14 & 49 & 3,17 & 2,39 \\
\hline Estrela & 4 & 7 & 2 & 2 & 2 & 12 & 5 & 0 & 16 & 50 & 3,43 & 1,98 \\
\hline Forrest & 0 & 15 & 11 & 8 & 2 & 9 & 5 & 0 & 0 & 50 & 2,44 & 0,78 \\
\hline IAC-4 & 5 & 4 & 6 & 4 & 2 & 3 & 11 & 1 & 12 & 48 & 3,29 & 2,00 \\
\hline Conquista $\times$ Cristalina & 41 & 15 & 9 & 15 & 4 & 21 & 23 & 0 & 19 & 147 & 2,66 & 2,04 \\
\hline Conquista $\times$ Estrela & 43 & 22 & 7 & 7 & 12 & 18 & 16 & 1 & 16 & 142 & 2,50 & 2,00 \\
\hline Conquista $x$ Forrest & 45 & 19 & 10 & 12 & 10 & 26 & 17 & 0 & 2 & 141 & 2,29 & 1,40 \\
\hline Conquista x IAC-4 & 64 & 13 & 5 & 7 & 8 & 18 & 18 & 0 & 8 & 141 & 2,20 & 1,83 \\
\hline Cristalina $x$ Estrela & 22 & 17 & 9 & 14 & 3 & 17 & 17 & 5 & 44 & 148 & 3,24 & 2,30 \\
\hline Cristalina $x$ Forrest & 22 & 22 & 19 & 11 & 6 & 20 & 28 & 2 & 16 & 146 & 2,80 & 1,76 \\
\hline Cristalina x IAC-4 & 18 & 15 & 10 & 19 & 9 & 23 & 28 & 0 & 18 & 140 & 2,98 & 1,63 \\
\hline Estrela x Forrest & 9 & 40 & 11 & 7 & 8 & 25 & 26 & 1 & 20 & 147 & 2,91 & 1,73 \\
\hline Estrela x IAC-4 & 32 & 8 & 9 & 4 & 5 & 16 & 35 & 3 & 34 & 146 & 3,20 & 2,29 \\
\hline Forrest x IAC-4 & 59 & 25 & 9 & 9 & 6 & 13 & 14 & 1 & 11 & 147 & 2,15 & 1,79 \\
\hline Total de Plantas & 383 & 234 & 122 & 131 & 82 & 237 & 253 & 16 & 231 & 1689 & 2,78 & 1,82 \\
\hline
\end{tabular}


APÊNDICE 8 - Resultados médios (média de cinco plantas/vaso) das avaliações de sintomas radiculares (severidade e comprimento da lesão) e foliares da PVR (severidade, incidência e índice de doença), na geração $F_{2}$ do dialelo $5 \times 5$ conduzido em telado (TE-JUL01). Soja, Piracicaba-SP.

\begin{tabular}{|c|c|c|c|c|c|}
\hline \multirow[b]{2}{*}{ Genótipos } & \multicolumn{2}{|c|}{ Sintomas Radiculares } & \multicolumn{3}{|c|}{ Sintomas Foliares } \\
\hline & $\begin{array}{c}\text { Severidade } \\
\qquad(1 \text { a } 5)\end{array}$ & $\begin{array}{l}\text { Comprimento } \\
\text { Lesão (mm) }\end{array}$ & $\begin{array}{l}\text { Severidade } \\
\qquad(1 \text { a } 5)\end{array}$ & $\begin{array}{c}\text { Incidência } \\
\text { (\%) }\end{array}$ & $\begin{array}{l}\text { Índice de } \\
\text { Doença }\end{array}$ \\
\hline Conquista & 2,58 & 6,7 & 1,92 & 80,0 & 31,6 \\
\hline Cristalina & 2,47 & 6,6 & 2,24 & 88,0 & 40,2 \\
\hline Estrela & 2,27 & 6,1 & 2,18 & 74,0 & 35,4 \\
\hline Forrest & 2,38 & 4,7 & 1,67 & 62,0 & 21,8 \\
\hline IAC-4 & 2,64 & 6,6 & 2,42 & 76,0 & 39,3 \\
\hline Conquista $\times$ Cristalina & 2,61 & 6,4 & 2,24 & 78,0 & 35,5 \\
\hline Conquista $x$ Estrela & 2,39 & 6,2 & 2,16 & 74,0 & 33,3 \\
\hline Conquista $\times$ Forrest & 2,48 & 6,4 & 1,83 & 70,0 & 27,3 \\
\hline Conquista $\times$ IAC-4 & 2,14 & 5,5 & 2,08 & 73,8 & 31,9 \\
\hline Cristalina $x$ Estrela & 2,46 & 6,5 & 2,23 & 82,7 & 38,2 \\
\hline Cristalina $\mathrm{x}$ Forrest & 2,38 & 6,5 & 2,11 & 84,0 & 36,4 \\
\hline Cristalina x IAC-4 & 2,55 & 6,6 & 2,37 & 83,3 & 40,2 \\
\hline Estrela $\times$ Forrest & 2,11 & 5,7 & 2,00 & 77,8 & 32,0 \\
\hline Estrela x IAC-4 & 2,11 & 5,0 & 2,19 & 78,2 & 35,8 \\
\hline Forrest $x \mid A C-4$ & 2,33 & 6,0 & 2,11 & 80,3 & 35,7 \\
\hline Média genitores & 2,47 & 6,1 & 2,09 & 76,0 & 33,7 \\
\hline Média $F_{2}$ & 2,36 & 6,1 & 2,13 & 78,2 & 34,6 \\
\hline Média geral & 2,39 & 6,1 & 2,12 & 77,5 & 34,3 \\
\hline
\end{tabular}


APÊNDICE 9 - Resultados médios (média de cinco plantas/vaso) das avaliações de sintomas foliares da PVR (severidade, incidência e índice de doença), na geração $F_{2}$ do dialelo $5 \times 5$ conduzido na casa de vegetação (CV-SET01). Soja, Piracicaba-SP.

\begin{tabular}{lccc}
\hline Genótipos & Severidade & Incidência (\%) & Índice de Doença \\
\hline Conquista & 1,73 & 84,0 & 29,8 \\
Cristalina & 2,15 & 98,0 & 42,4 \\
Estrela & 2,29 & 98,0 & 45,2 \\
Forrest & 1,91 & 92,0 & 36,5 \\
IAC-4 & 1,71 & 98,0 & 33,6 \\
Conquista x Cristalina & 1,74 & 89,3 & 31,8 \\
Conquista x Estrela & 2,09 & 92,7 & 39,6 \\
Conquista x Forrest & 1,85 & 88,7 & 33,6 \\
Conquista x IAC-4 & 1,87 & 85,3 & 33,1 \\
Cristalina x Estrela & 2,17 & 96,0 & 41,9 \\
Cristalina x Forrest & 2,01 & 96,0 & 38,8 \\
Cristalina x IAC-4 & 1,99 & 90,7 & 36,6 \\
Estrela x Forrest & 1,99 & 84,0 & 34,7 \\
Estrela x IAC-4 & 2,07 & 90,0 & 38,1 \\
Forrest x IAC-4 & 1,98 & 87,3 & 35,8 \\
\hline Média genitores & 1,96 & 94,0 & 37,5 \\
\hline Média F & 1,98 & 90,0 & 36,4 \\
\hline Média geral & 1,97 & 91,3 & 36,8 \\
\hline
\end{tabular}


APÊNDICE 10 - Resultados médios (média de cinco plantas/vaso) das avaliações de severidade (notas 1 a 5) e índice de doença dos sintomas foliares da PVR, considerando a nota do folíolo com sintomas mais intensos (SF e IDF) ou o aspecto geral da planta (SP e IDP), incidência em porcentagem (IP\%) e severidade desconsiderando plantas com nota de aspecto geral igual a 1 (SP1), na geração $F_{2}$ do dialelo $5 \times 5$ conduzido em casa de vegetação (CVJUL02). Soja, Piracicaba-SP.

\begin{tabular}{|c|c|c|c|c|c|c|}
\hline Genótipos & SF & IDF & IP\% & $\mathrm{SP}$ & IDP & $\mathrm{SP} 1^{1}$ \\
\hline Conquista & 2,83 & 48,5 & 83,5 & 2,47 & 42,4 & 2,80 \\
\hline Cristalina & 3,34 & 58,3 & 78,0 & 3,16 & 55,1 & 3,82 \\
\hline Estrela & 3,77 & 70,4 & 92,0 & 3,43 & 64,0 & 3,64 \\
\hline Forrest & 2,71 & 54,2 & 100,0 & 2,44 & 48,8 & 2,44 \\
\hline IAC-4 & 3,60 & 64,9 & 90,0 & 3,30 & 59,7 & 3,56 \\
\hline Conquista $\times$ Cristalina & 2,98 & 47,1 & 72,0 & 2,64 & 41,5 & 3,28 \\
\hline Conquista $\times$ Estrela & 2,77 & 41,0 & 69,3 & 2,51 & 36,9 & 3,17 \\
\hline Conquista $\times$ Forrest & 2,55 & 37,5 & 65,9 & 2,25 & 33,0 & 2,92 \\
\hline Conquista $\times$ IAC-4 & 2,46 & 30,6 & 54,2 & 2,18 & 26,6 & 3,24 \\
\hline Cristalina $x$ Estrela & 3,55 & 63,7 & 85,3 & 3,26 & 58,5 & 3,63 \\
\hline Cristalina $x$ Forrest & 3,11 & 54,0 & 84,7 & 2,79 & 48,5 & 3,13 \\
\hline Cristalina x IAC-4 & 3,34 & 60,0 & 87,2 & 2,97 & 53,5 & 3,24 \\
\hline Estrela x Forrest & 3,25 & 61,4 & 93,4 & 2,90 & 54,6 & 3,03 \\
\hline Estrela x IAC-4 & 3,46 & 58,3 & 78,2 & 3,18 & 53,4 & 3,72 \\
\hline Forrest $x$ IAC-4 & 2,38 & 31,9 & 60,2 & 2,15 & 28,7 & 2,81 \\
\hline Média genitores & 3,25 & 59,3 & 88,7 & 2,96 & 54,0 & 3,25 \\
\hline Média $F_{2}$ & 2,98 & 48,5 & 75,0 & 2,68 & 43,5 & 3,22 \\
\hline Média geral & 3,07 & 52,1 & 79,6 & 2,78 & 47,0 & 3,23 \\
\hline
\end{tabular}

Plantas com nota de aspecto geral igual a 1 foram consideradas escapes e não participaram das análises. 
APÊNDICE 11 - Análise química do solo utilizado nos experimentos na casa de vegetação em 2001 e 2002 (CV-SET01 e CV-JUL02) com a geração $F_{2}$ do dialelo 5x5. Soja, Piracicaba-SP.

\begin{tabular}{|c|c|c|c|c|c|c|c|c|c|c|c|c|c|c|}
\hline $\mathrm{pH}$ & . & $\mathrm{P}$ & S & 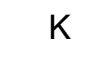 & a & . & וזר & & . & B & . & 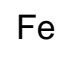 & $\mathrm{Mn}$ & $\mathrm{Zn}$ \\
\hline \multicolumn{2}{|c|}{$\mathrm{CaCl}_{2}\left(\mathrm{~g} \mathrm{dm}^{-3}\right)$} & \multicolumn{2}{|c|}{$\left(\mathrm{mg} \mathrm{dm}^{-3}\right)$} & \multicolumn{6}{|c|}{ 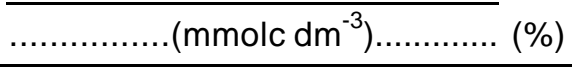 } & & & & & \\
\hline 5, & (2) & 266 & 11 & 7 & 130 & ? & & 3 & 8 & 0 & 0,9 & 70 & 3,0 & 0,3 \\
\hline
\end{tabular}

APÊNDICE 12 - Análise foliar de amostras da cultivar Forrest e do cruzamento Conquista $x$ Cristalina no experimento da casa de vegetação em 2002 (CV-JUL02) com a geração $F_{2}$ do dialelo $5 \times 5$. Soja, Piracicaba-SP.

\begin{tabular}{|c|c|c|c|c|c|c|c|c|c|c|c|}
\hline \multirow[b]{2}{*}{ Amostra } & $\mathrm{N}$ & $P$ & $\mathrm{~K}$ & $\mathrm{Ca}$ & $\mathrm{Mg}$ & S & $\mathrm{B}$ & $\mathrm{Cu}$ & $\mathrm{Fe}$ & $\mathrm{Mn}$ & $\mathrm{Zn}$ \\
\hline & \multicolumn{11}{|c|}{ 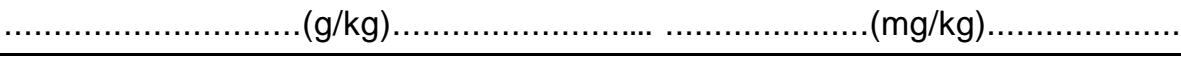 } \\
\hline Forrest & 41,4 & 2,9 & 20,0 & 14,7 & 3,3 & 2,9 & 51 & 7,0 & 182 & 124 & 55 \\
\hline Conq. $x$ Cristal. & 51,8 & 3,5 & 25,4 & 9,8 & 3,3 & 5,3 & 43 & 8,0 & 180 & 100 & 39 \\
\hline
\end{tabular}



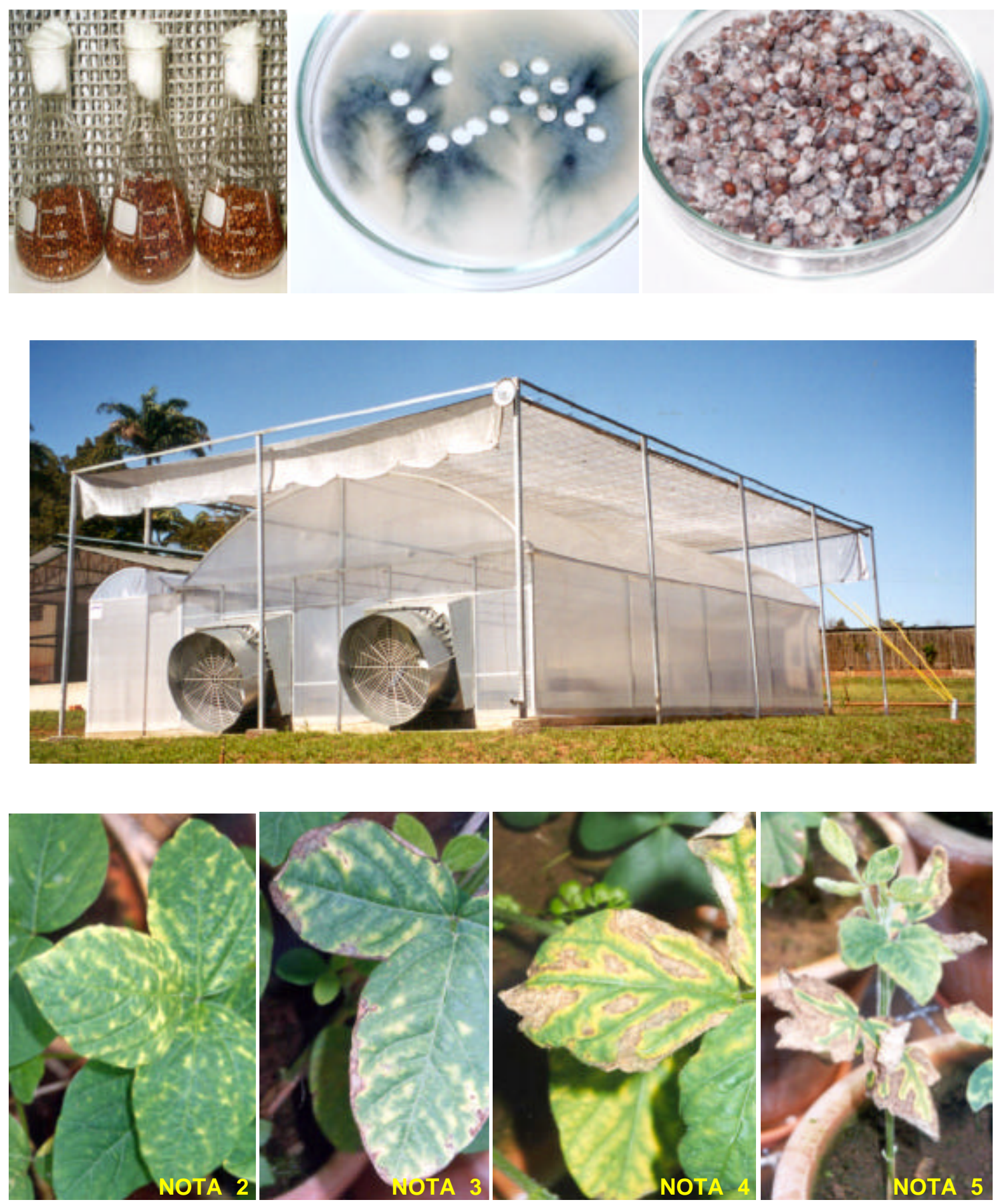

APÊNDICE 13 - Detalhes do inóculo, da casa de vegetação e da escala de notas. 